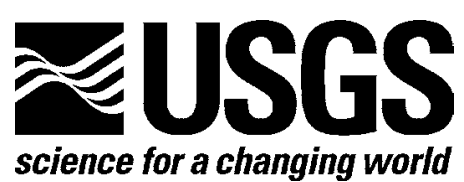

Prepared in cooperation with Puget Sound Nearshore Ecosystem Restoration Project

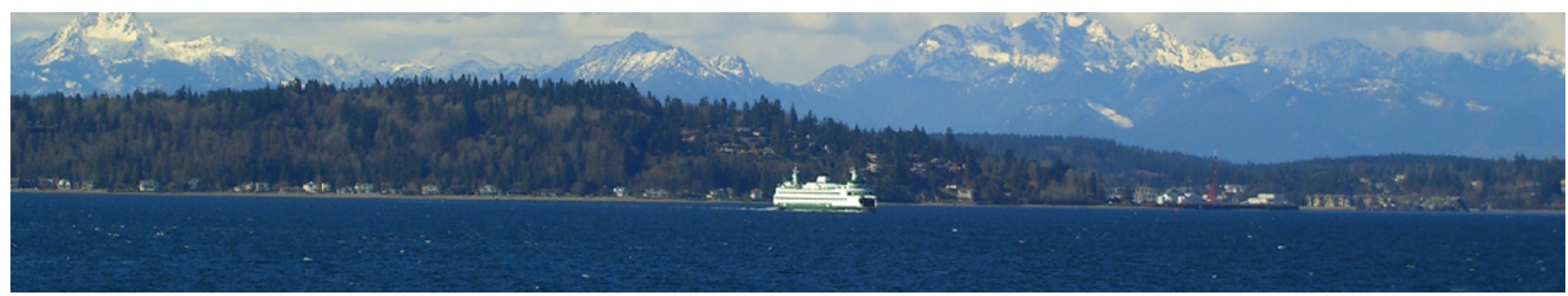

\title{
Extended Abstracts from the Coastal Habitats in Puget Sound (CHIPS) 2006 Workshop
}

Fort Worden State Park

Port Townsend, Washington

November 14-16, 2006

Edited by Guy Gelfenbaum, Tracy L. Fuentes, Jeffrey J. Duda, Eric E. Grossman, and Renee K. Takesue

Open-File Report 2009-1218

U.S. Department of the Interior

U.S. Geological Survey 


\section{U.S. Department of the Interior \\ KEN SALAZAR, Secretary}

\section{U.S. Geological Survey \\ Marcia K. McNutt, Director}

U.S. Geological Survey, Reston, Virginia: 2010

For more information on the USGS—-the Federal source for science about the Earth, its natural and living resources, natural hazards, and the environment, visit http://www.usgs.gov or call 1-888-ASK-USGS.

For an overview of USGS information products, including maps, imagery, and publications, visit $h$ ttp://www.usgs.gov/pubprod

To order this and other USGS information products, visit http://store.usgs.gov

Suggested citation:

Gelfenbaum, G., Fuentes, T.L., Duda, J.J., Grossman, E.E., and Takesue, R.K., eds., 2010, Extended abstracts from the Coastal Habitats in Puget Sound (CHIPS) 2006 Workshop, Port Townsend, Washington, November 14-16, 2006: U.S. Geological Survey Open-File Report 2009-1218, 136 p.

Any use of trade, product, or firm names is for descriptive purposes only and does not imply endorsement by the U.S. Government.

Although this report is in the public domain, permission must be secured from the individual copyright owners to reproduce any copyrighted material contained within this report. 


\section{Contents}

Introduction .

Restoration of Large River Deltas-Project Overview

Using Influence Diagrams to Structure Skagit Restoration Conceptual Models..

Incorporating Stakeholder Preferences into Decision-Making on Skagit River Delta Restoration.

Characterizing Modern Nearshore Habitats and Physical Processes Influencing Habitat Availability near the

Skagit River Delta

Suspended Sediment Transport in the Skagit River Delta—Recent Measurements ......................................................17

Conceptual Models of Nitrate and Pesticides Sources and Their Cycling in Aquatic Environments .....................................19

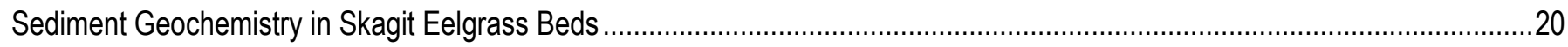

Organic Matter Composition of Sediment in Nearshore Ecosystems of Puget Sound, Washington ..........................................22

Habitat Use and Timing by Bull Trout in Marine Waters of Northern Puget Sound, Washington ...............................................39

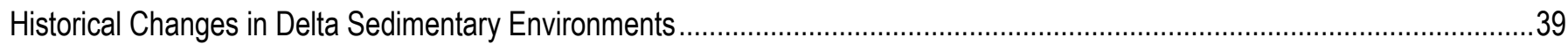

Arrival and Expansion of the Invasive Foraminifer Trochammina hadai Uchio in Padilla Bay, Washington...............................44

A Multi-Index Biomarker Approach to Understanding the Paleo-Occurrence of Eelgrass (Zostera marina) in the

Nearshore of Puget Sound, Washington

Developing Models of Restoration Impacts to Nearshore Systems

Consequences of the Elwha River Dam Removal on Nearshore Habitats and Ecosystems_Project Overview

Beach and Nearshore Sedimentary Environments-Elwha River, Washington.

Linking Puget Sound Rivers to the Nearshore: Physical Processes and Nutrient Dynamics in the Lower Elwha River

Evaluating Fish Responses to Removal of the Elwha River Dams in Shallow Water Coastal Habitats Adjacent to the

Elwha River Mouth

Using Otolith Analysis to Establish Habitat Use Patterns of Migrating Juvenile Chinook Salmon in the Elwha River.

Monitoring Sediment and Channel Geometry on the Lower Elwha River, Washington, in Preparation for Dam

Removal.......

Effects of Urbanization on Nearshore Processes and Ecosystems: Liberty Bay

Urban Metrics Correlated with Reduced Herring Spawn in Liberty Bay and Port Orchard, Puget Sound, Washington 88

Temporal Variability in Salinity, Temperature, and Chlorophyll a in Liberty Bay, Washington 


\section{Contents-Continued}

Eelgrass, Bottom Sediment, Nutrients, and Wastewater Contaminants in Liberty Bay, Washington.........................................96

Tracking Wastewater Inputs and Trophic Dynamics with Stable Isotopes in Liberty Bay, Washington ...................................105

Coastal Habitats in Puget Sound (CHIPS) Urbanization Task FY07 Research Plans ..........................................................106

Nearshore Sediment Dynamics at Possession Point, Whidbey Island, Washington.............................................................108

Marine Fish Health Research at the Marrowstone Marine Field Station, Nordland, Washington...........................................110

Dissolved Inorganic Loads to Lynch Cove, Hood Canal, Washington .......................................................................111

A Geochemical and Geophysical Examination of Submarine Groundwater Discharge and Associated Nutrient

Loading Estimates into Lynch Cove, Hood Canal, Washington ................................................................................112

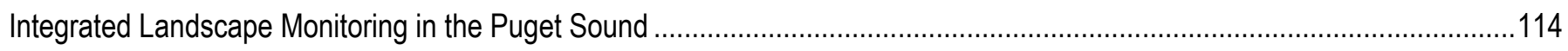

Long-Term Hydrodynamic and Morphological Modeling for the Deschutes River Estuary Feasibility Study, Washington

Recent Science-Based Restoration Planning by Puget Sound Nearshore Ecosystem Restoration Project (PSNERP) .............119

Nearshore Habitat Program of the Washington Department of Natural Resources ......................................................125 


\section{Extended Abstracts from the Coastal Habitats in Puget Sound (CHIPS) 2006 Workshop}

Edited by Guy Gelfenbaum, Tracy L. Fuentes, Jeffrey J. Duda, Eric E. Grossman, and Renee K. Takesue

\section{Introduction}

By Guy Gelfenbaum 1

Puget Sound is the second largest estuary in the United States. Its unique geology, climate, and nutrient-rich waters produce and sustain biologically productive coastal habitats. These same natural characteristics also contribute to a high quality of life that has led to a significant growth in human population and associated development. This population growth, and the accompanying rural and urban development, has played a role in degrading Puget Sound ecosystems, including declines in fish and wildlife populations, water-quality issues, and loss and degradation of coastal habitats.

In response to these ecosystem declines and the potential for strategic large-scale preservation and restoration, a coalition of local, State, and Federal agencies, including the private sector, Tribes, and local universities, initiated the Puget Sound Nearshore Ecosystem Restoration Project (PSNERP). The Nearshore Science Team (NST) of PSNERP, along with the U.S. Geological Survey, developed a Science Strategy and Research Plan (Gelfenbaum and others, 2006) to help guide science activities associated with nearshore ecosystem restoration. Implementation of the Research Plan includes a call for State and Federal agencies to direct scientific studies to support PSNERP information needs. In addition, the overall Science Strategy promotes greater communication with decision makers and dissemination of scientific results to the broader scientific community.

\footnotetext{
${ }^{1}$ U.S. Geological Survey, Coastal and Marine Geology; 345 Middlefield Road, MS 999, Menlo Park, CA 94025; ggelfenbaum@usgs.gov
} 
On November 14-16, 2006, the U.S. Geological Survey sponsored an interdisciplinary Coastal Habitats in Puget Sound (CHIPS) Research Workshop at Fort Worden State Park, Port Townsend, Washington. The main goals of the workshop were to coordinate, integrate, and link research on the nearshore of Puget Sound. Presented research focused on three themes:

(1) restoration of large river deltas; (2) recovery of the nearshore ecosystem of the Elwha River; and (3) effects of urbanization on nearshore ecosystems. The more than 35 presentations covered a wide range of ongoing inter-disciplinary research, including studies of sediment geochemistry of aquatic environments, sediment budgets, tracking fish pathways, expansion of invasive forams, beach and nearshore sedimentary environments, using influence diagrams as a decision support tool, forage fish, submarine groundwater, and much, much more.

The primary focus within these themes was on developing information on the physical, chemical, and biological processes, as well as the human dimensions, associated with the restoration or rehabilitation of the nearshore environment. The workshop was an excellent opportunity for USGS scientists and collaborators who are working on Puget Sound coastal habitats to present their preliminary findings, discuss upcoming research, and to identify opportunities for interdisciplinary collaboration.

A compilation of extended abstracts from workshop participants, this proceedings

volume serves as a useful reference for attendees of the workshop and for those unable to attend. Taken together, the abstracts in this report provide a view of the current status of USGS multidisciplinary research on Puget Sound coastal habitats.

\section{Reference Cited}

Gelfenbaum, G., Mumford, T., Brennan, J., Case, H., Dethier, M., Fresh, K., Goetz, F., van Heeswijk, M., Leschine, T.M., Logsdon, M., Myers, D., Newton, J., Shipman, H., Simenstad, C.A., Tanner, C., and Woodson, D., 2006, Coastal Habitats in Puget Sound: A research plan in support of the Puget Sound Nearshore Partnership: Puget Sound Nearshore Partnership Report No. 2006-1. Published by the U.S. Geological Survey, Seattle, Washington. Available at http://pugetsoundnearshore.org

\section{Acknowledgments}

We acknowledge the contributions of Anne Kinsinger, John Stein, Frank Shipley, Cindi Barton, Susan Benjamin, Lyman Thorsteinson, Lief Horwitz, and Robert Koeppen to strategic discussions about the Puget Sound nearshore. The majority of research described in this report is being funded by the USGS Coastal and Marine Geology Program, which is coordinated by John Haines. We especially thank our partners and collaborators with the Puget Sound Nearshore Ecosystem Restoration Project, in particular Timothy Smith, Bernie Hargrave, Curtis Tanner, and all members of the Nearshore Science Team. We thank Aaron Prestegard for preparing the conference program and Douglas George for editing the final report. We also thank two anonymous reviewers for many useful comments. 


\section{Agenda \\ COASTAL HABITATS IN PUGET SOUND \\ USGS Research Workshop \\ November 14-16, 2006 \\ Fort Worden State Park}

\section{November 13}

Arrive at meeting venue. Informal gathering.

\section{November 14}

8:00 am Arrive at meeting room. Coffee and Tea

8:30 Welcome, goals of the workshop, logistics

Gelfenbaum

8:45 Regional and National perspective

Kinsinger, Haines

9:00 Introduction to Large River Deltas Science Plan

9:15 Using influence diagrams to structure Skagit restoration conceptual models

$9: 30$

Incorporating stakeholder preferences into decision-making on Skagit restoration

$9: 45$

Modern benthic habitats and water column properties

Grossman

Labiosa

Sexton/Koontz

10:00 The organic geochemistry of sediments from Skagit Delta: PAH

indicators of contamination

10:15 Characterizing sediment redox and metals in eelgrass habitats: what

conditions affect success

10:30 Break, Coffee and Tea

11:00 Pore-water chemistry and habitat

11:15 Tracking Travis Trout (or Bull Trout in Nearshore Habitats)

11:25 Prospecting in ear stones (or Otoliths to assess the tidal delta as nursery habitat)

11:35 Skagit River sediment sampling: improving discharge estimates and the sediment budget

$11: 50$

Nearshore circulation and habitat availability

12:05 Historical changes in delta sedimentary environments

$12: 15$

Arrival and expansion of the invasive foraminifer T. hadai in Padilla Bay

Lipid biomarkers as proxies of past eelgrass presence/abundance

Grossman

Rosenbauer

Takesue

Paulson

Reisenbichler

Reisenbichler

Mastin

Grossman/Curran

Grossman

McGann

Rosenbauer

1:00 Lunch - Commons

2:00 Consequences of the Elwha River dam removal on nearshore habitats and ecosystems- Project overview

Beach and nearshore sedimentary environments

Current profile and extent of freshwater conditions in Elwha River estuary

Duda

Warrick

Konrad

Duda

Gelfenbaum

Duda

Draut

Short field trip to local beach (walk, jog, or run)

6:30 Dinner-Commons 


\section{November 15}

8:00 am Arrive in meeting room. Coffee and Tea

8:30 Urbanization Task: conceptual framework and recent progress

Takesue

$8: 50$

9:10

9:30

9:50

Queija/Watts

Takesue

Lacy

Rondorf

10:10 Break, Coffee and Tea

10:40 Discussion of Urbanization task future studies

Takesue

11:00 Possession Point

Lacy

11:20 Forage fish studies

11:40 Urban NAWQA - Effects of Urbanization on Stream Ecosystems

Hershberger

Black

12:00 Lunch

1:30 Nearshore contaminants issues

1:50 Submarine Ground-Water Discharge to Hood Canal:

2:10 Puget Sound Pilot - Integrated Landscape Monitoring

2:30 Hood Canal

2:50 Deschutes Estuary Feasibility Study

West or O’Neill

Swarrzenski

Torgersen

Paulson/Simonds

Gelfenbaum

3:10 Break, soft drinks

3:40 PSNERP update

4:00 Nearshore science issues (typology, change analysis

Tanner

Simenstad

4:20 Another partner talk or General discussion

5:00 Adjourn

7:00 Dinner - informal gatherings

\section{November 16}

8:00 am Arrive at meeting room

8:30 Directions for Break-Out Groups $\quad$ Gelfenbaum

8:45 Break-Out Group Discussion

10:30 Report back from Break-Out Groups

11:30 Final thoughts

Shipley

12:00 End of Meeting 


\title{
Restoration of Large River Deltas-Project Overview
}

\author{
By Eric Grossman ${ }^{1}$
}

\section{Abstract}

Historical development and ongoing restoration of large river deltas affect many Puget Sound salmon species and ESA-listed taxa and populations. In particular, direct loss of habitat and migratory pathways and the alteration of fluvial and tidal processes in deltas appear to have resulted in increased density dependent mortality of many life history types of salmonids, including Skagit River Chinook (Oncorhynchus tshawytscha) migrant fry, tidal delta fry, and parr migrants. In addition, channelization, diking, and drainage of historically productive wetlands have altered estuarine mixing, sedimentation and erosion patterns, and organic matter cycling in nearshore settings. This has resulted in alteration of eelgrass (Zostera marina) meadows, forage fish spawning and rearing sites, and pocket estuaries that support salmon and the foodweb. Researchers with the U.S. Geological Survey Coastal Habitats in Puget Sound (CHIPS) project on Restoration of Large River Deltas have identified a number of stressors on nearshore delta habitats in Puget Sound. The Skagit Delta-Whidbey Basin (fig. 1) is the initial task focus.

Key Words: Deltas, restoration, salmon, eelgrass, habitat

The CHIPS Restoration of Large River Deltas task has five principal subtasks to integrate research and approaches, with the goal of developing predictive models and tools to help manage resources in a manner to balance ecologic and socioeconomic needs. These subtasks are (1) to characterize modern habitats; (2) to characterize modern habitat use; (3) to quantify modern processes; (4) to quantify historical habitat change; and, (5) to develop decision support tools to guide land use and resource management. Initial efforts are to develop information for these five areas, with a specific focus on understanding land use impacts to habitats and processes along juvenile Chinook migration pathways through the delta and nearshore. Improving understanding of and the interactions between habitat, habitat change, habitat use, land use and processes will ultimately lead to improved capacity to restore habitat function (fig. 2) in large river delta systems in the Puget Sound.

\footnotetext{
${ }^{1}$ U.S. Geological Survey, Western Coastal and Marine Geology Program Pacific Science Center, 400 Natural Bridges Dr., Santa Cruz, CA 95060; egrossman@usgs.gov
} 


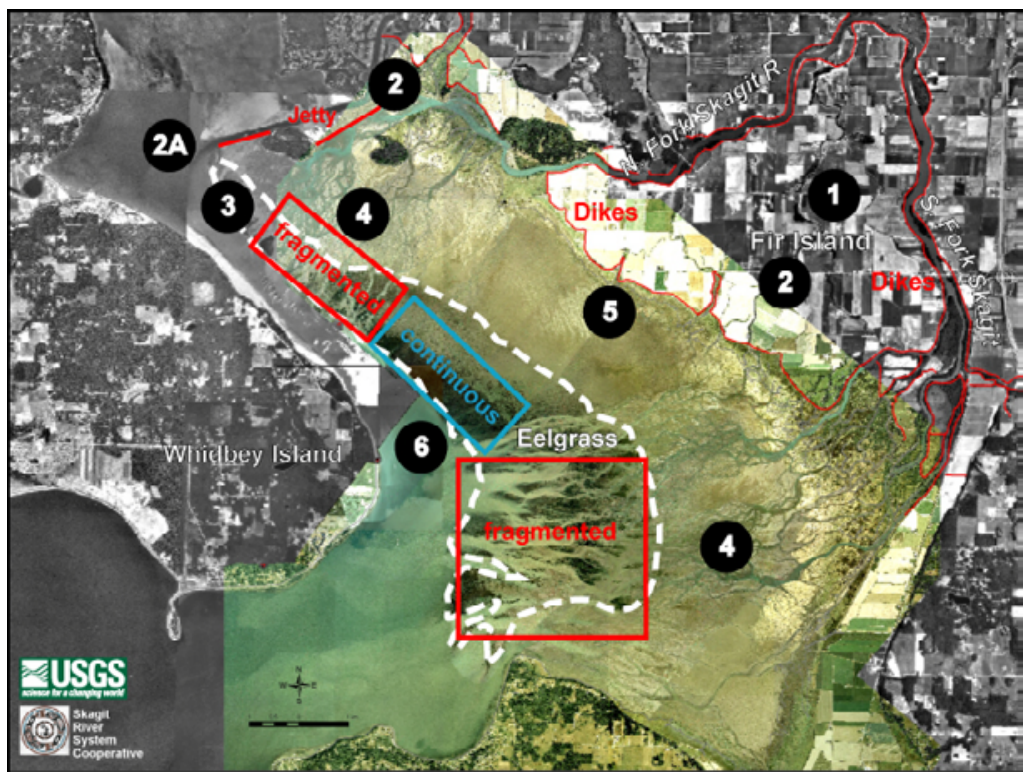

Figure 1. Six principal issues stemming from land use in large river deltas, as represented in the central Skagit River Delta: (1) loss of wetlands and marsh distributary channel habitat, (2) loss of salmon migration pathways, (3) alteration of estuarine mixing due to river flow channelization, (4) sedimentation due to increased river flow velocities stemming from river channelization, (5) coastal erosion due to reduced sediment inputs because of bayfront diking, and (6) altered water quality due to changes in organic matter, nutrient and contaminant export.

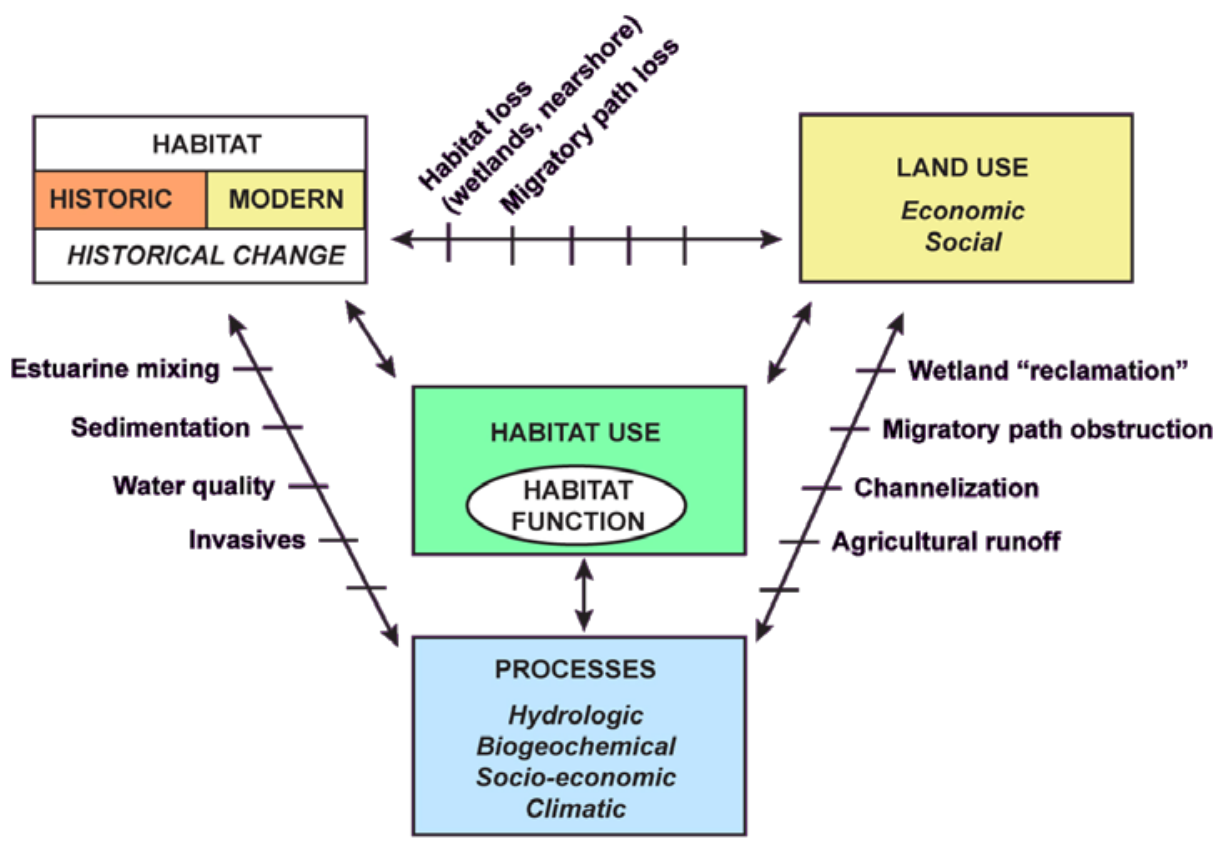

Figure 2. Conceptual model showing the influence and interdependence between habitat, habitat change, habitat use, land use, and processes on habitat function. 


\title{
Using Influence Diagrams to Structure Skagit Restoration Conceptual Models
}

\author{
By Bill Labiosa1 and Eric Grossman²
}

\begin{abstract}
Influence diagrams are decision-framing tools that graphically represent a decision problem in terms of the relations between the considered alternatives, uncertainties about the consequences of choosing particular alternatives, and the performance measures relevant to decisionmakers, experts, and stakeholders (Howard and Matheson, 1984; Howard, 1990; Labiosa and others, 2003). In restoration decisions, the relations between alternative restoration plans and future restoration outcomes are causal. However, there may be significant uncertainty in predicting restoration outcomes, because of data gaps, knowledge gaps, and natural variability in environmental and ecological drivers.

Decisionmakers and technical experts/scientists can use influence diagrams to accurately describe the decision to be made, to determine information and forecasting requirements, and to identify data needs. The influence diagram displays the physical, economic, and social relationships between the important variables in the decision situation, including decision strategies, uncertain variables describing the state and response of the natural system, and variables related to valuing outcomes. During data collection and scientific model development, the influence diagram is updated to reflect our improved understanding. Thus, the influence diagram evolves during the restoration support process.

Sensitivity analysis may be used to determine which, if any, uncertainties can be treated deterministically, as well as which variables drive the most uncertainty in the predicted outcomes. "Uncertainties that matter" are here defined as those for which a resolution in information could lead to a shift in the preferred alternative. An example of a restoration project conceptual model as an influence diagram is shown in figure 1, based on a conceptual model of the McGlinn Island causeway-breaching project (Beamer and others, 2005). The uncertainties include future regional climate change and its effects on discharge in the North Fork of the Skagit River; the effects of the causeway breaching alternatives on the salinity gradient, salmon habitat availability, and sediment inputs to Swinomish Channel; the effects of sediment inputs on channel navigation; and the effects of habitat availability on salmon survival. Several of these uncertain variables also are performance measures, as indicated by arrows into the multi-attribute utility node, "Restoration success."
\end{abstract}

Key Words: Decision support, restoration conceptual models, sensitivity analysis, uncertainty

1U.S. Geological Survey, 345 Middlefield, MS 531, Menlo Park, CA 94025, blabiosa@usgs.gov

2U.S. Geological Survey, Western Coastal and Marine Geology Program Pacific Science Center, 400 Natural Bridges Dr., Santa Cruz, CA 95060; egrossman@usgs.gov 


\section{References Cited}

Beamer, E., Bernard, R., Hayma, B., Hebner, B., Hinton, S., Hood, G., Kraemer, C., McBride, A., Musslewhite, J., Smith, D., Wasserman, L., and Wyman, K., 2005, Skagit Chinook Recovery Plan: Skagit River System Cooperative and Washington Department of Fish and Wildlife Report, Version 13.0. (http://www.skagitcoop.org/).

Howard, R.A., 1990, From influence to relevance to knowledge, in Oliver, R.M., and Smith, J.Q., eds., Influence Diagrams, Belief Nets, and Decision Analysis: Chichester, Wiley. Howard, R.A., and Matheson, J.E., 1984, Influence Diagrams, in Howard, R.A., and Matheson, J.E., eds., The Principles and Applications of Decision Analysis: Menlo Park, Strategic Decisions Group.

Labiosa, W.B., Leckie, J.O., Mumley, T., Rytuba, J., and Berknopf, R., 2003, A decision analysis approach to TMDL implementation decisions: Mercury TMDLs in the San Francisco Bay Area: Proceedings of the National TMDL Science and Policy Specialty Conference, Water Environment Federation, November 16-19, 2003.

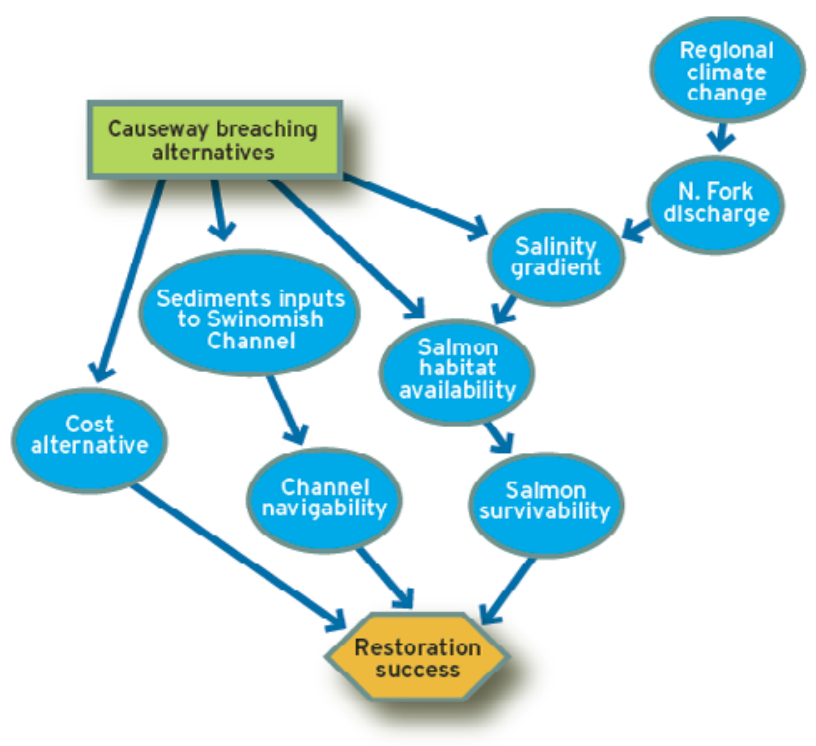

Figure 1. Example of an influence diagram for the McGlinn Island causeway breaching decision. 


\title{
Incorporating Stakeholder Preferences into Decision- Making on Skagit River Delta Restoration
}

\author{
By Natalie Sexton ${ }^{1}$ and Lynne Koontz ${ }^{2}$
}

\begin{abstract}
Assessing public perceptions of different habitat restoration strategies can provide decision makers with valuable insights regarding the advantages and disadvantages of options and the societal tradeoffs associated with each prior to implementation. Having objective data on stakeholder concerns can help enhance the public process by documenting the views of those who may normally not participate or speak out at standard forums such as public meetings. The Policy Analysis and Science Assistance Branch of the USGS Fort Collins Science Center conducts research in this arena, drawing from a multitude of disciplines, including economics, social psychology, political science, and communication. We outline conceptual approaches to obtaining and quantifying stakeholder preferences in the decision process (fig. 1) and provide an overview of these efforts in the Skagit area.
\end{abstract}

Key Words: public preferences, societal tradeoffs, socioeconomics, stakeholders

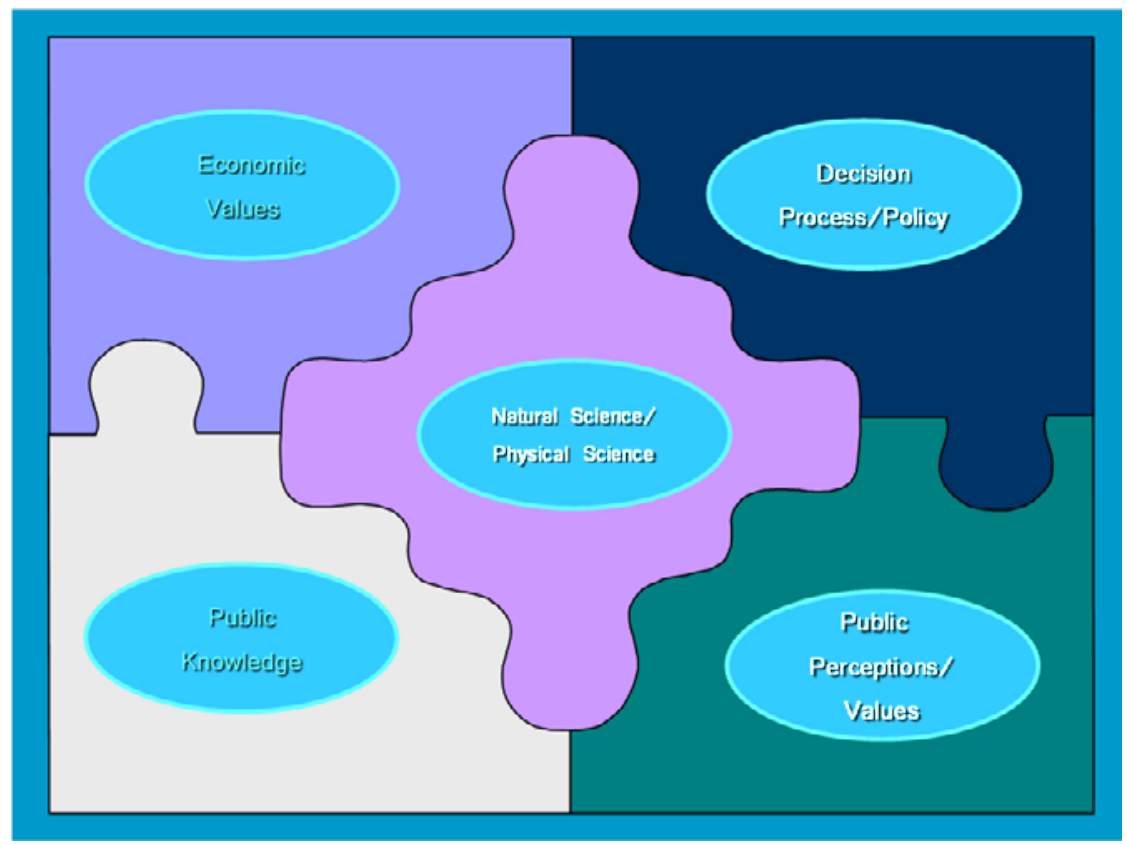

Figure 1. Factors affecting natural resource decision making.

1U.S. Geological Survey, Fort Collins Science Center, 2150 Centre Ave., Bldg. C, Fort Collins, C0 80526; sexton@usgs.gov 2 U.S. Geological Survey, Fort Collins Science Center, 2150 Centre Ave., Bldg. C, Fort Collins, CO 80526; koontzl@usgs.gov 


\title{
Characterizing Modern Nearshore Habitats and Physical Processes Influencing Habitat Availability near the Skagit River Delta
}

\author{
By Eric Grossman ${ }^{1}$
}

\begin{abstract}
Active restoration of Puget Sound lowlands to support salmon recovery is planned and ongoing, despite limited understanding of the modern distribution and function of nearshore habitats. How habitats may change as hydrodynamic and biogeochemical processes are affected by land use, including restoration also is unknown. Historical loss of nearshore habitat may be decreasing Skagit River Chinook salmon (Oncorhynchus tshawytscha) survival rates through density dependent mortality; pocket estuaries may be essential nursery grounds for juvenile Chinook salmon. However, it remains uncertain what habitats exist and what functions they provide to juvenile salmonids. Hence, quantifying the availability and role of nearshore habitats (eelgrass (Zostera marina) meadows, pocket estuaries, and tide flat fringes) to endangered salmonids and the food web provide important criteria for seeking restoration outcomes. The U.S. Geological Survey Coastal Habitats in Puget Sound (CHIPS) project on Restoration of Large River Deltas is mapping benthic and water column properties of these nearshore habitats and quantifying the hydrodynamic processes that shape the habitat availability (fig. 1). Initial focus is on the Skagit Delta along two principal migratory pathways for juvenile Skagit Chinook to help quantify land use impacts and restoration outcomes (figs. 2 and 3).
\end{abstract}

Key Words: habitat, nearshore, delta, Skagit, salmon, eelgrass, sediment, mapping, circulation

\section{Characterization of Benthic Habitat}

With partners from Skagit River System Cooperative and Washington Department of Natural Resources Vegetation Mapping Program, we are using submersible video to enumerate eelgrass coverage, to document recent change to eelgrass cover, and to characterize additional benthic habitat attributes to generate maps of benthic habitat cover (figs. 3 and 4).

1U.S. Geological Survey, Western Coastal and Marine Geology Program, Pacific Science Center, 400 Natural Bridges Dr., Santa Cruz, CA 95060; egrossman@usgs.gov 
Bathymetric data collected with swath sonar and synthesized with topographic and bathymetric LIDAR (LIght Detecting And Ranging) reveal the complexity of the Skagit Delta nearshore. Offshore of the channelized north and south forks of the Skagit River, the substrate is characterized by braided morphology (fig. 5). Modest relief (1-2 m) of meandering channels cutting across the entire delta indicates that active sediment transport processes characterize the area and may contribute to the fragmentation of the Skagit eelgrass meadows. Meanders may have migrated farther distances in the southeastern portion of the North Fork fragmented eelgrass area than to the north. Differences in meander migration may indicate that the active flow regime associated with the braided morphology may be migrating southward since 2000 and into the intact eelgrass to the south. Eelgrass meadows offshore of the diked bayfront of central Fir Island appear to be isolated from the active sediment transport of the North and South Forks and currently remain intact, likely because of reduced sediment inputs.

Acoustic backscatter data appear to image eelgrass well. Dense eelgrass produces a fine mesh pattern that is distinct from substrate textural and bedform features (fig. 6). Fragmented eelgrass areas reveal distinct substrate textures, including mound structures that can be observed in aerial photography. These mound structures are likely associated with former eelgrass patches.

\section{Variability in Benthic and Water Column Habitat}

The CHIPS project on Restoration of Large River Deltas is mapping additional benthic habitat characteristics including sediment grain size, composition, and organic matter along principal juvenile Chinook salmon migratory pathways with focus on nursery and forage habitats. In addition, we are characterizing variability in nearshore circulation and water column properties that influence habitat availability and connectivity using fixed and boat-mounted current profilers, water level sensors, and profiling conductivity, temperature, and depth (CTD) sensors. These data help to show how currents move in the nearshore, as well as the spatial and temporal variability of surface water temperature, salinity, and turbidity, which influence habitat quality for fish and vegetation and migratory pathways for juvenile salmon smolts.

Figure 7 shows one ADCP (Acoustic Doppler Current Profiling) transect, representing average current and backscatter (a proxy for particulate concentration) across Skagit Bay at the North Fork, over the course of about 15 minutes, during a falling tide in June 2006. River outflow conditions were typical of late spring-early summer snowmelt discharge and represented conditions common of juvenile Chinook salmon outmigration. Relatively high surface current velocities $(100-150 \mathrm{~cm} / \mathrm{s})$ and high particulate concentrations associated with the North Fork river plume extend well into Skagit Bay, reducing light availability for eelgrass that occurs in depth less than 2-3 m. In the absence of sufficient fish passages between the North Fork and principal nursery grounds to the north, juvenile Chinook salmon are likely transported into central Skagit Bay because of high current velocities associated with channelized river flow.

Figure 8 shows that a freshwater lens also extends into Skagit Bay, likely driven by the high velocities of the North Fork Skagit River plume. At times, this lens may extend to Whidbey Island. When this lens contracts, salmon smolts entrained in the lens would find themselves abruptly displaced into high salinity marine waters, where a steep salinity gradient occurs. This physiological stressor may contribute to juvenile salmon mortality. 
Time series measurements and repeat spatial surveys of these parameters enable us to characterize the variability in benthic and water column habitat availability. Together, these data help to characterize the distribution of nearshore habitats in the Skagit Delta and to quantify the hydrodynamic processes that shape them and influence their spatial and temporal availability to the food web. Understanding this variability will enable scientists and resource managers to better predict habitat availability with future land use decisions.

\section{References Cited}

Beamer, E., Bernard, R, Hayma, B., Hebner, B., Hinton, S., Hood, G., Kraemer, C., McBride, A., Musslewhite, J., Smith, D., Wasserman, L, and Wyman, K., 2005, Skagit Chinook Recovery Plan: Skagit River System Cooperative and Washington Department of Fish and Wildlife Report, Version 13.0. Available on the World Wide Web: (http://www.skagitcoop.org/) 


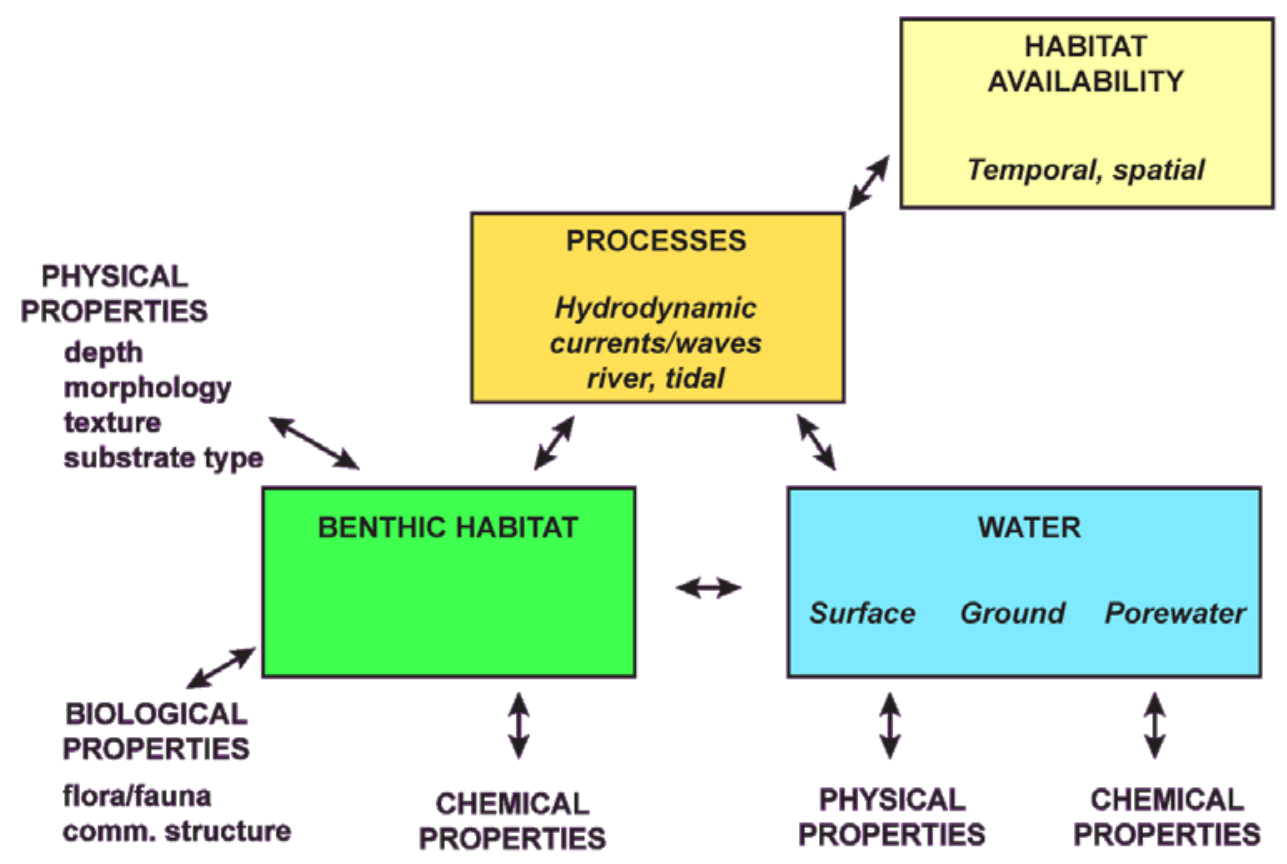

Figure 1. Conceptual model showing how hydrodynamic processes shape habitat availability in the Skagit River delta.

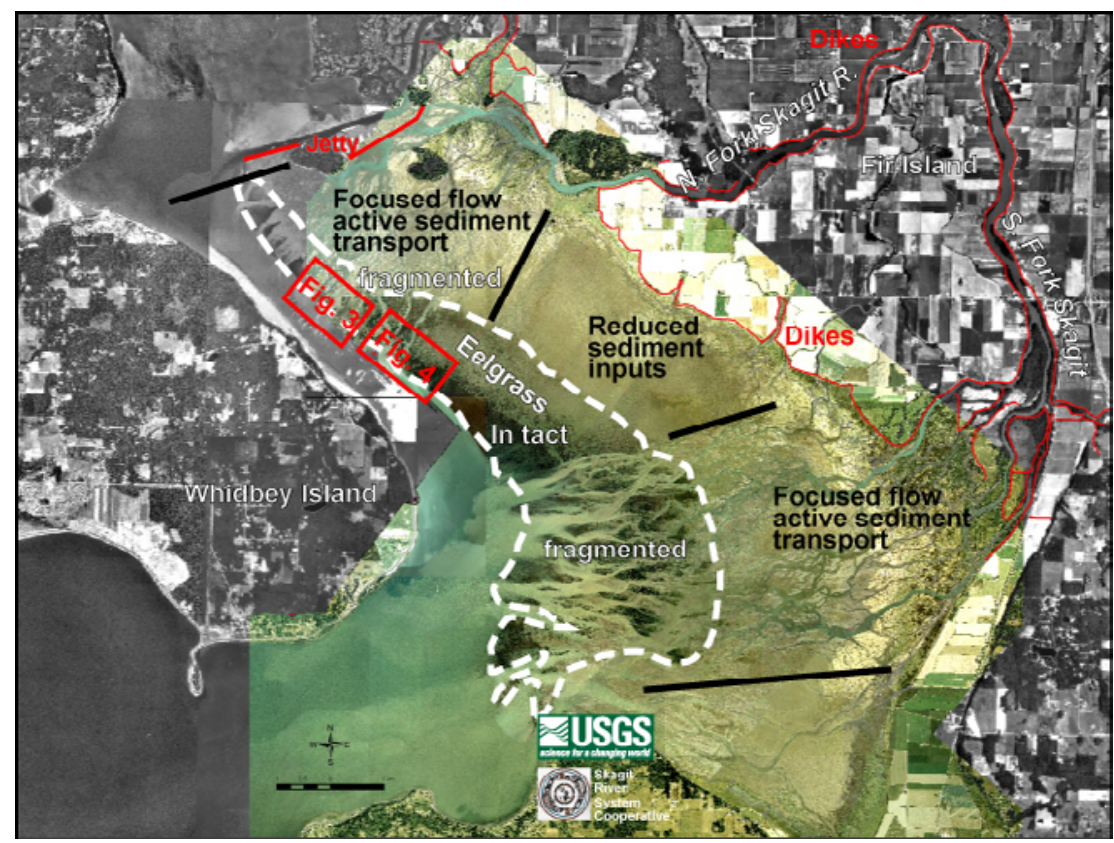

Figure 2. Interpreted aerial photograph showing fragmented eelgrass offshore of channelized flow and intact eelgrass offshore of the diked Fir Island bayfront where sediment input has been reduced. 


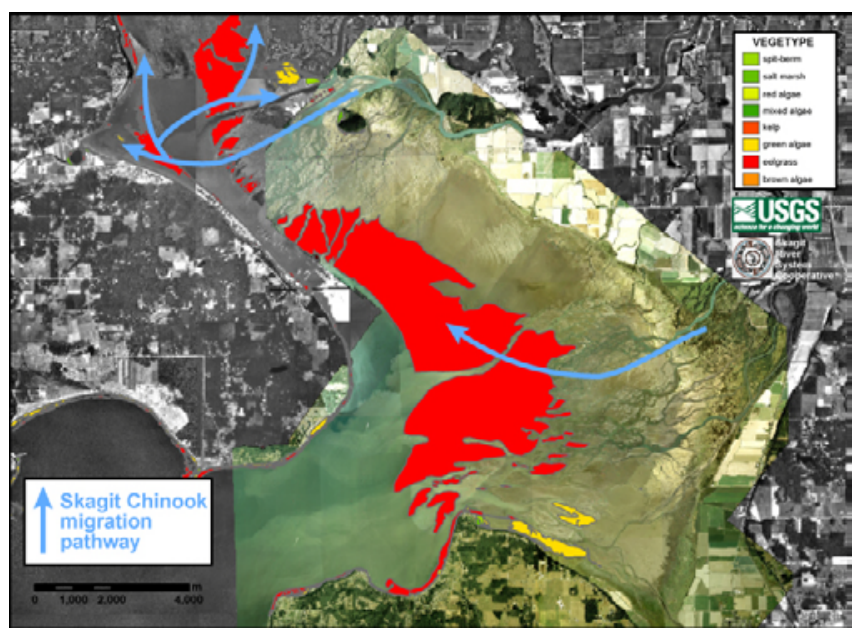

Figure 3. Nearshore vegetated habitats (McBride, Skagit Cooperative, written commun., 2006) interpreted from true-color photography flown in 2000 and principal Skagit Chinook migratory pathways (Beamer and others, 2006).

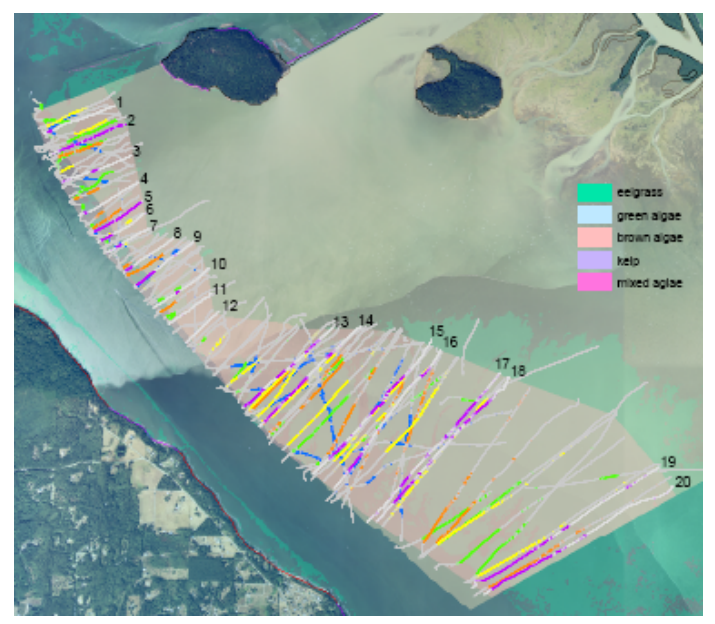

Figure 4. Location of video transect data of eelgrass and algae cover courtesy of Washington DNR that will be used to characterize additional benthic habitat traits and change to eelgrass cover since 2000 . 


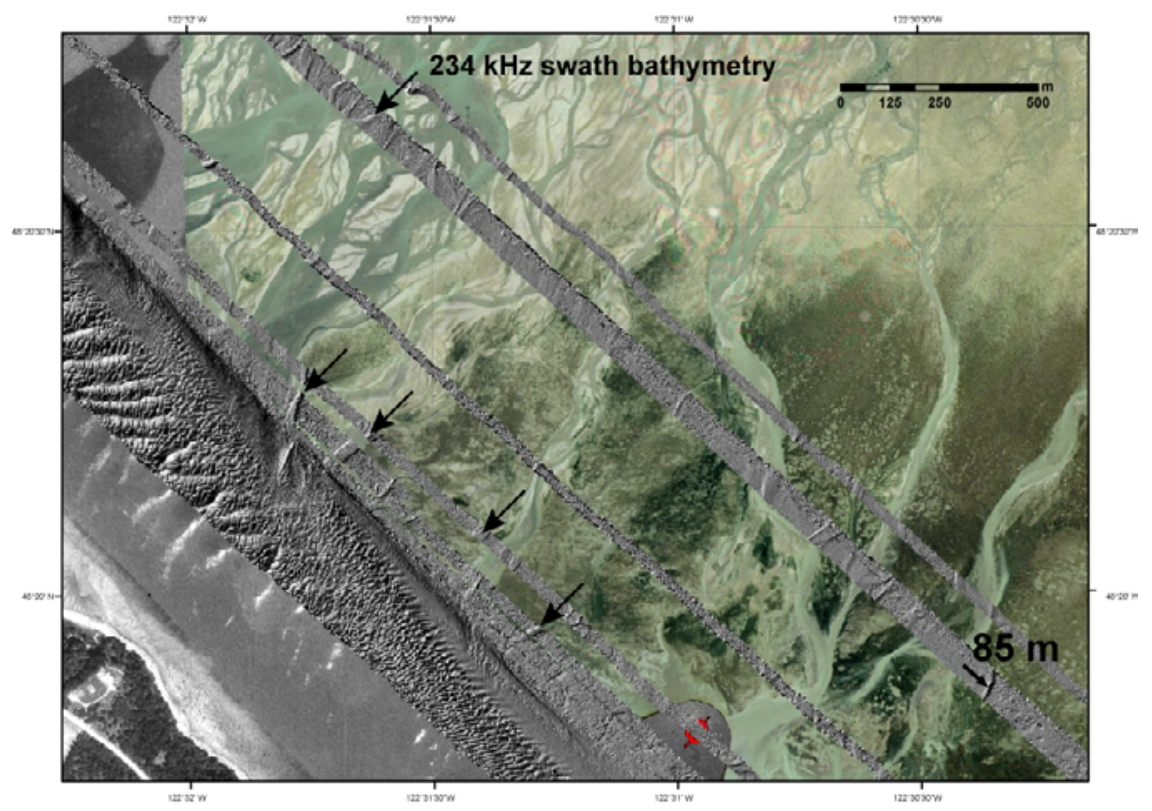

Figure 5. Gridded bathymetry collected in 2005 georeferenced to true color aerial photography from July 2000 shows meandering stream channel relief of 1-2 $\mathrm{m}$ (arrows) across the delta front and active channel migration of $85 \mathrm{~m} \mathrm{(17} \mathrm{m/yr)} \mathrm{in} \mathrm{some} \mathrm{areas} \mathrm{(southeast} \mathrm{corner).}$

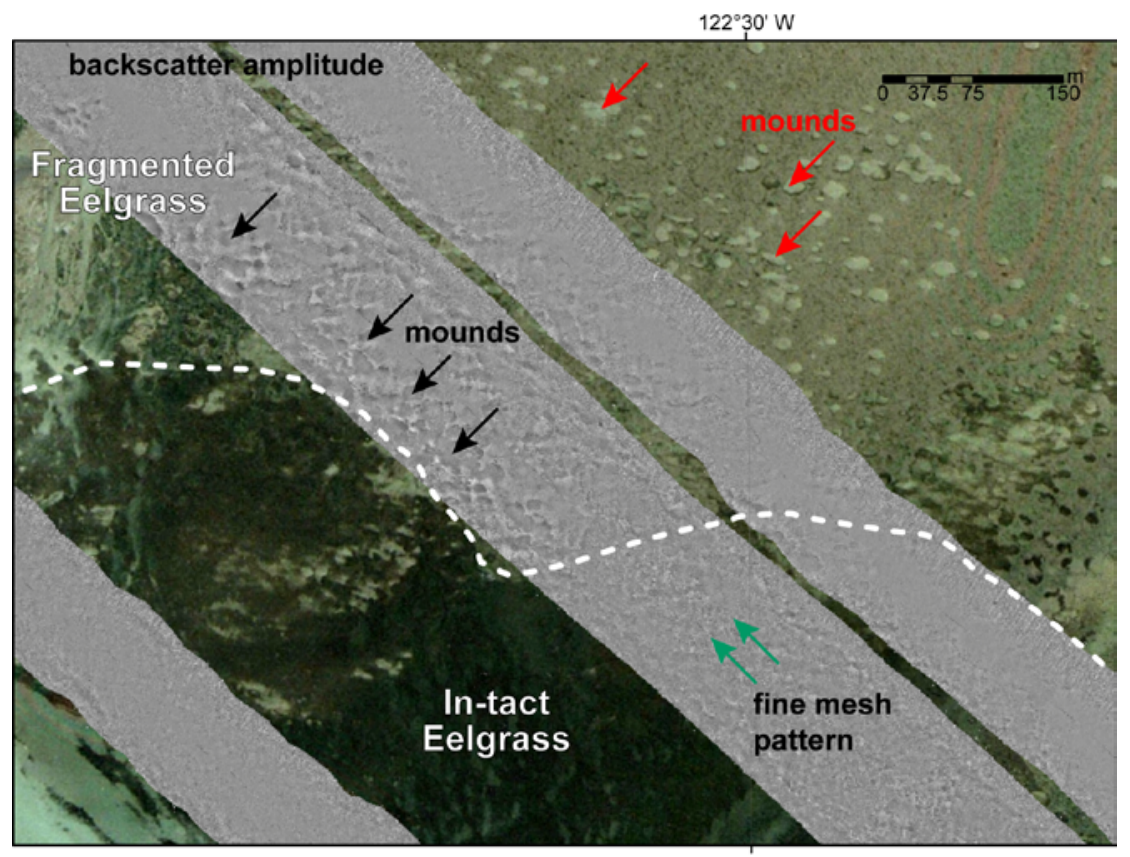

$122^{\circ} 30^{\prime} \mathrm{W}$

Figure 6. Mosaic of backscatter amplitude showing distinct eelgrass signature (green arrow) and mound structures (black arrows) associated with past eelgrass patches (also in photography (red arrows). 


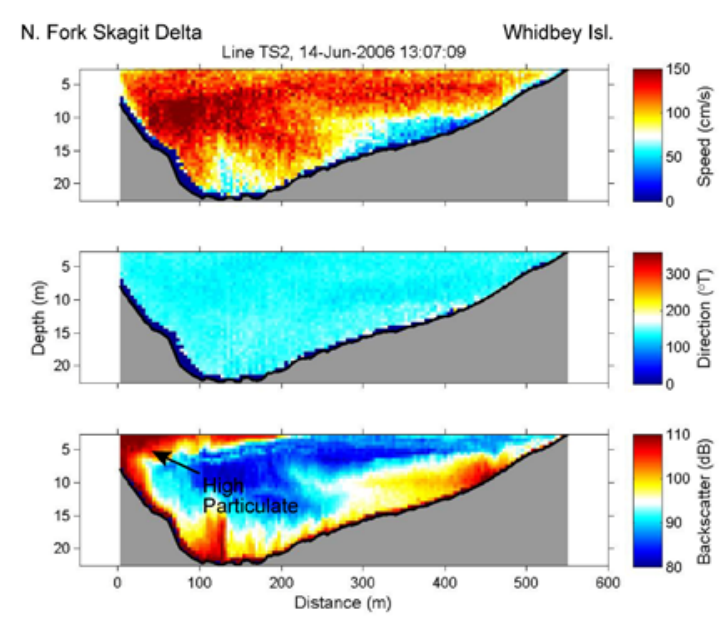

Figure 7. Boat-mounted ADCP profiles show high current velocities and backscatter (a proxy for high particulate concentration) associated with the North Fork Skagit River plume as it enters Skagit Bay from the left.

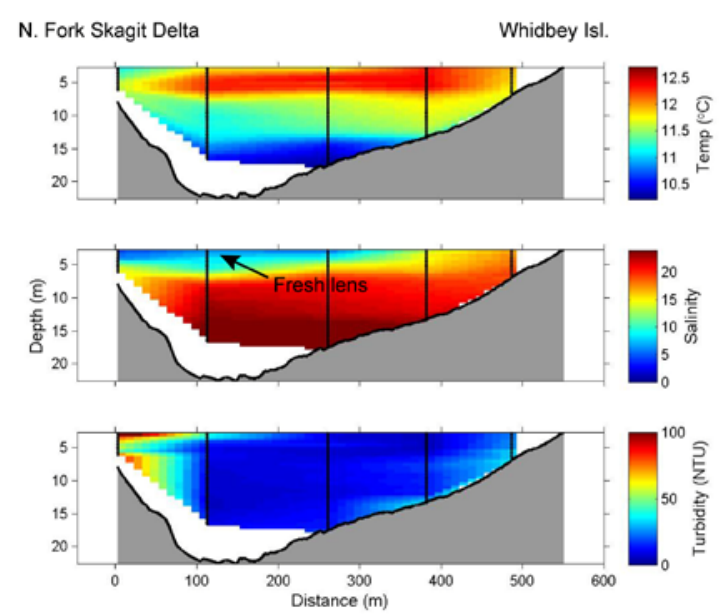

Figure 8. Gridded CTD profile data for the same time period in figure 7 (sites at black bars) reveal that a surface fresh water lens can extend into and perhaps across the Skagit Bay. 


\title{
Suspended Sediment Transport in the Skagit River Delta- Recent Measurements
}

\author{
By Mark Mastin 1
}

\begin{abstract}
The largest river in the Puget Sound basin, the Skagit River, drains $8,030 \mathrm{~km}^{2}$. Annual Chinook salmon (Oncorhynchus tshawytscha) catches in Skagit Bay and Skagit River have declined from 40,000 to 50,000 in the 1930 s to 1,000 or fewer in the 1990 s. The declining salmon catch is related to the loss of important rearing habitats for salmon (pocket estuaries, marsh channels in the delta region, and eelgrass (Zostera marina) beds in the nearshore environment). Although the Skagit River delta historically supported about 10,400 ha of wetlands, only about 785 ha remain. Most were directly converted to agricultural lands, through the establishment of levees and elimination of distributary channels. Excessive sediment deposition may be responsible for the fragmentation and loss of eelgrass beds. Recent habitat restoration efforts have focused on re-establishing historical connections between the river and the delta region to increase access to pocket estuaries and to increase the area of tidal wetlands. These restoration activities affect the redistribution of sediments in the delta and nearshore. Without understanding the sediment budget and circulation patterns of sediment from the Skagit River, it will be unclear how these restoration efforts will affect sediment deposition and erosion, which in turn, may make it unclear how they affect the nearshore habitats. The U.S. Geological Survey's Washington Water Science Center is developing a program to quantify suspended sediment rates on the Skagit River near Mt. Vernon and to improve estimates of the complete sediment budget for the Skagit River basin.
\end{abstract}

Key Words: Sediment sampling, suspended sediment, Skagit River

${ }^{1}$ U.S. Geological Survey, Washington Water Science Center, 934 Broadway, Ste 300, Tacoma, WA, 98402; mcmastin@usgs.gov 


\section{Sediment Sampling}

The U.S. Geological Survey's Washington Water Science Center installed two pump samplers in March 2006 to collect daily suspended-sediment samples at its streamgaging station on the Skagit River near Mt. Vernon (fig. 1). Four equal-discharge-interval (EDI) samples were taken at the bridge near the station to calibrate the suspended sediment concentrations from the pump-sampler samples to an average value for the cross section.

Concentrations of suspended sediment in the EDI samples ranged from 88 to $494 \mathrm{mg} / \mathrm{L}$ at stream discharges from 312 to $1,120 \mathrm{~m}^{3} / \mathrm{s}\left(11,000\right.$ to $\left.39,600 \mathrm{ft}^{3} / \mathrm{s}\right)$. Suspended-sediment discharge ranged from 2,370 to 47,900 metric tons/d. Values from a set of five EDI samples from November 13-14, 2006, during the rise of a large peak (peak flow was $3,120 \mathrm{~m}^{3} / \mathrm{s}$ or $110,000 \mathrm{ft}^{3} / \mathrm{s}$ ), will help provide a picture of the changing sediment transport dynamics during a large peak discharge and improve the sediment rating curve at the site.

A continuous daily record of suspended-sediment transport will be calculated using the sediment concentration of the pump-sampler samples corrected to represent the average concentration in the cross section and applied to the discharge hydrograph using the U.S. Geological Survey's Graphical Constituent Loading Analysis System. If funding is secured, the program of sediment sampling with the pump sampler and EDI sampling from the bridge will continue and eventually provide a long-term, accurate record of suspended sediment at the site and improve estimates of the complete sediment budget for the Skagit River basin.

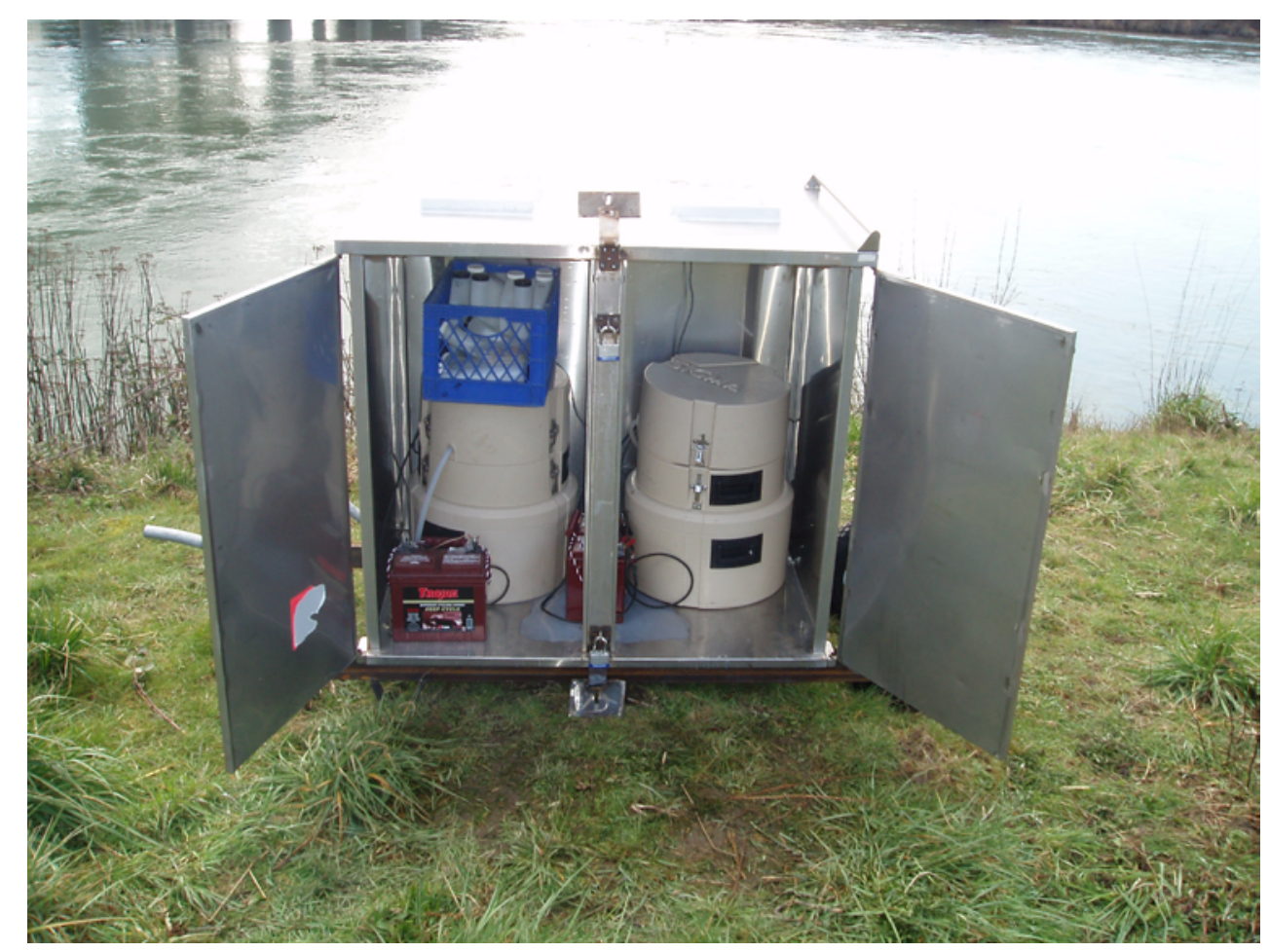

Figure 1. Dual sediment pump samplers in steel box on the right bank of the Skagit River near the USGS streamgaging station, Skagit River near Mt. Vernon, WA. 


\title{
Conceptual Models of Nitrate and Pesticides Sources and Their Cycling in Aquatic Environments
}

\author{
By Anthony Paulson 1
}

\begin{abstract}
The availability and cycling of organic matter partially controls fish growth in estuaries. Organic matter originates from terrestrial and oceanic sources, as well as marine primary productivity. Primary productivity may be limited by dissolved inorganic nitrogen from either terrestrial or marine sources. In FY 2008 and beyond, the Large Delta Project will address the biogeochemistry of carbon, nitrogen, and sulfur in the Skagit Delta - Whidbey Basin Study. The cycling of insecticides and herbicides are closely related to the cycling of organic matter. Pesticides applied to agricultural and other lands can escape to the aquatic environment, where sub-lethal effects, such as impaired homing abilities on fish, have been observed. The conceptual models of the National Water Quality Assessment (NAWQA) program for nutrients and pesticides will be adapted to the study of the biogeochemistry of the Skagit Delta - Whidbey Basin.
\end{abstract}

Key Words: Biogeochemistry, carbon, nutrients, and pesticides 


\title{
Sediment Geochemistry in Skagit Eelgrass Beds
}

\author{
By Renee Takesue 1
}

\section{Abstract}

Eelgrass (Zostera marina) provides habitat for fish, shellfish, and invertebrates and food for waterfowl and detritus-feeders. It also affects nearshore sedimentary biogeochemical cycles of oxygen, nutrients, and metals. Eelgrass grows in a variety of nearshore environments in Skagit Bay, from enclosed pocket estuaries to the open delta front. The varied geochemical and physical energy conditions in the Skagit delta (SD), over Pull and Be Damned (PBD) mud flat north of the Swinomish channel jetty, and in Lone Tree Lagoon pocket estuary (LTL) provide an opportunity to explore the range of conditions habitable for eelgrass.

Key Words: Sediment, redox, geochemistry, eelgrass, Skagit River

\section{Approach}

We measured sediment reduction-oxidation potential (redox), total sedimentary metals, and grain size in the root zones of eelgrass beds in September 2006. Sediment redox reflects aerobic and anaerobic microbial consumption of sedimentary organic matter. The higher the organic content of sediments, the more negative the redox value, measured in units of millivolts $(\mathrm{mV})$. In strongly reducing sediments, anaerobic sulfate reduction produces sulfide, which is toxic to marine plants and inhibits eelgrass growth (Terrados and others, 1999). Thus, sediment redox is a qualitative indicator of the suitability of sediments for eelgrass growth.

In the presence of free sulfides, redox-sensitive sedimentary metals, such as cadmium and zinc, precipitate as insoluble sulfides and may accumulate to high levels. High concentrations of redox-sensitive metals are qualitative measures of strongly reducing sediments. High sedimentary metal concentrations also indicate present-day inputs associated with land use.

Sediment grain size reflects the physical energy environment. Low energy environments, characterized by fine sediments ( $<63 \mu \mathrm{m}$, silt+clay), may be unfavorable for eelgrass growth. Fine sediments inhibit pore water-bottom water exchange; water residence time is longer in low energy environments (Koch, 2001).

\section{Sediment Core Collection and Processing}

We collected push cores (3"-diameter, 12"-long acid-cleaned polycarbonate tubes) from eelgrass beds at sites EC-1 (SD), EM-6 (PDB), and PE-1 (LTL) for geochemical analyses. We capped and sealed sediment cores with overlying water. We stored cores on ice until we returned to the lab, and we processed them in an oxygen-free environment $\left(\mathrm{N}_{2}\right.$ glove bag). Time elapsed between collection and processing was no more than a few hours.

1U.S. Geological Survey, Coastal and Marine Geology, 400 Natural Bridges Drive, Santa Cruz, CA, 95060; rtakesue@usgs.gov 
To produce a flat working surface for sediment redox measurements, we split cores longitudinally in the glove bag with a nylon spatula. We used a platinum-calomel microelectrode (Lazar Research Laboratory) to measure sediment redox. Before each downcore redox profile, we polished the microelectrode to remove surface oxides and calibrated it to a quinhydrone reference solution $\left(+200 \mathrm{mV}\right.$ at $\left.25^{\circ} \mathrm{C}\right)$. We then inserted the microelectrode into the flat working surface of the split core, so that the $2 \mathrm{~mm}$-long tip of the microelectrode was surrounded by sediment. We measured sediment redox values every $0.5 \mathrm{~cm}$ in regions of strong gradients and every $1.0 \mathrm{~cm}$ in the rest of cores.

After measuring the downcore redox profile, we subsampled the undisturbed half of the core for sedimentary metals. We removed approximately 5-10 grams of wet sediment from each 1-cm interval, transferred the sediment to $20 \mathrm{~mL}$ acid-cleaned polyethylene scintillation vials with polypropylene caps. We refrigerated the sedimentary metal samples for later analysis. Finally, the sediment core was removed from the $\mathrm{N}_{2}$ glove bag, sliced into $1 \mathrm{~cm}$ intervals, and placed in $2 \mathrm{oz}$ Whirl-Pak bags for grain-size analyses.

\section{Sediment Grain Size and Total Metal Processing and Analyses}

We weighed approximately 2 grams of wet sediment and dried it overnight at $105^{\circ} \mathrm{C}$. To determine water content, we cooled the sediment for 1 hour in a desiccator and then re-weighed it. We used an agate mortar and pestle to gently disaggregate dry sediments, and then split them with an aluminum micro-splitter. A Gilson SS-3 electromagnetic tapping sieve shaker shook approximately 1 gram of dry sediment through 3"-diameter stainless steel sieves $(500,250,125$, and $63 \mu \mathrm{m}$ ) for 12 minutes. We then weighed size fractions to determine grain size distributions.

We processed the fine fraction $(<63 \mu \mathrm{m})$ according to U.S. Environmental Protection Agency Method 3052, a microwave-assisted total sediment digestion method for sedimentary trace metals, using concentrated nitric and hydrofluoric acid. Samples were digested, evaporated to dryness, and reconstituted in a 2 percent nitric acid (Optima ${ }^{\mathrm{TM}}$ grade) solution containing 100 ppb germanium as an internal standard. We analyzed metal concentrations using an Element high-resolution sector-field inductively coupled plasma mass spectrometer (ICP-MS) at the Institute of Marine Sciences at the University of California in Santa Cruz. We processed sedimentary reference materials from the National Institute of Standards and Technology (2702, 1646a) and the Canadian Certified Reference Materials Project (STSD-2, STSD-3) in the same manner as unknown samples and used them for external calibration. Analytical uncertainties, calculated a $1 \sigma$ of STSD-2 ( $=5$ ), were 0.01 ppm (cadmium), 0.1 ppm (arsenic, copper), 0.4 ppm (nickel), 1 ppm (chromium, zinc), and 4 ppm (lead). Detection limits, calculated as three times the standard deviation of the blank, were $0.04 \mathrm{ppm}$ (cadmium) and $\leq 1 \mathrm{ppm}$ (all others).

\section{Results}

\section{Sediment Redox}

Sedimentary redox conditions ranged from well oxygenated in SD surface sediments (+200 mV, fig. 1a) to strongly reducing in LTL (-300 mV, fig. 1b). Sediments below $2 \mathrm{~cm}$ depth in PBD eelgrass beds were intermediate between the two extremes $(-100$ to $-150 \mathrm{mV})$ and moderately reducing (fig. 1a). For comparison, sulfate reduction occurs below about $-150 \mathrm{mV}$ (Connell and Patrick, 1967). 
There was a sharp redox gradient $(\Delta=350 \mathrm{mV})$ from oxygenated to reducing conditions in the upper $2 \mathrm{~cm}$ of the SD core (fig. 1a). This shift to reducing conditions coincided with the presence of black sediments. In contrast, the upper $2 \mathrm{~cm}$ of sediment of an eelgrass bed in LTL had a weak redox gradient $(\Delta=100 \mathrm{mV})$, while the upper $2 \mathrm{~cm}$ of a macroalgae (Ulva sp.) bed in LTL had no redox gradient (fig. 1b).

Below $2 \mathrm{~cm}$ depth, downcore redox values were slightly less reducing in LTL sediments underlying a patch of eelgrass $(-195 \pm 26 \mathrm{mV}, \mathrm{n}=14)$ than macroalgae $(-251 \pm 27 \mathrm{mV}, \mathrm{n}=13)$. Eelgrass roots may have caused this offset, by exuding oxygen into surrounding sediments during photosynthesis. The eelgrass patch in LTL also was closer to the seawater inflow than the macroalgae bed, so the difference in redox values at the two LTL sites may reflect increased flushing of bottom water over the eelgrass bed with oxygenated seawater. Poorly oxygenated bottom water over the macroalgae bed in LTL would be consistent with the lack of a redox gradient in the upper $2 \mathrm{~cm}$ of the sediment.

\section{Sedimentary Metal Concentrations}

We measured sedimentary metal concentrations in cores SD (EC-1) and LTL (eelgrass site), and the average concentrations were below levels of concern mandated by Washington State (table 1). Note that metal concentrations given for PBD are from a push core collected in September 2004. Despite the 2-year time difference, concentrations generally were similar among the three sites.

The black, reducing layer $(1-2 \mathrm{~cm})$ in sediments from the SD eelgrass bed had twice as much arsenic as underlying sediments and slightly higher concentrations of barium, a tracer of terrestrial input. Aluminum concentrations, indicative of the lithogenic fraction, did not vary across this layer. Sediment at 3-4 cm depth at SD had elevated concentrations of cadmium (41 ppm) and zinc (496 ppm), as well as slightly elevated lead concentrations (68 ppm). It is uncertain whether such high concentrations were real or due to contamination during sample processing.

\section{Sediment Grain Size}

Sediments in the SD consisted of medium to fine sand, with a very low percentage of fines ( 3 percent, fig. 2a). The fine fraction increased sharply to 10 percent in a distinct layer between 1-3 cm; the increase coincided with a sharp redox gradient, black sediments, and twofold higher arsenic concentrations. Below $3 \mathrm{~cm}$, the percentage of fines returned to low levels. Sediment texture was much finer at PBD, where surface sediments had 45-52 percent fines and smaller percentages of very fine sand. The downcore grain size distribution at PBD has not yet been analyzed.

Both sites in LTL showed a fining upward trend, from about 5 percent fines at $15 \mathrm{~cm}$ depth to about 40 percent fines at the surface (fig. 2b). Grain size distribution in sediments at the LTL macroalgae bed are semi-quantitative, because pebbles $>2 \mathrm{~mm}$ in diameter, which occurred throughout the core, were not included in fractional weight calculations. Such poorly sorted sediments probably resulted from overwash of beach gravel and pebbles into LTL at high tide, coupled with inputs of terrigenous sediment and organic matter from a small creek. 


\section{Discussion}

Sediment redox conditions, metal concentrations, and grain size in the root zones of eelgrass beds in SD, PBD, and LTL were similar to those in other eelgrass beds around Puget Sound. All parameters were favorable for eelgrass growth. The one exception may have been strongly reducing conditions in LTL sediments beneath a macroalgae (Ulva sp.) bed. Such low redox values could have resulted from the absence of eelgrass (which oxygenates sediments in its root zone), from a high degree of burial of organic matter (which drives reducing conditions), or both. Although we have not yet measured sedimentary organic contents at any of the sites, we expect them to be highest in LTL, because waves and currents, which winnow away fine sediments and organic matter, were negligible.

Eelgrass plants in LTL grew in small isolated patches, less than $2 \mathrm{~m}^{2}$; leaves were about $50 \mathrm{~cm}$ long. Negative redox values in the upper $2 \mathrm{~cm}$ of sediment in LTL cores suggest that bottom waters were depleted in oxygen relative to seawater. In future years, it would be interesting to explore how seasonal changes in LTL water and sediment properties correspond with changes in eelgrass growth, patch size, and use by fish.

The burial of a $1 \mathrm{~cm}$-thick organic- and arsenic-enriched layer on the Skagit delta front raised questions about possible geochemical impacts of restoration activities on the nearshore. Arsenic is one of several heavy metals that enter the environment through the application of phosphate fertilizers (Mortvedt, 1996; Otero and others, 2005). If land previously used for agriculture is flooded and reconnected to the nearshore, nutrients, organic carbon, heavy metals, pesticides, and fertilizers formerly sequestered in agricultural soils would be transported downstream and would enter the nearshore (Devai and DeLaune, 1995). Restoration activities should attempt to estimate, monitor, and, if necessary, mitigate the effects of these inputs on nearshore communities and food webs.

\section{Conclusions}

Sedimentary geochemical properties on the Skagit delta front were favorable for eelgrass growth. The physical environment was sufficiently energetic to remove all but a very small fraction of fine sediments (mud). Sediments were only moderately reducing. The ability of eelgrass beds to attenuate current energy and to trap fine sediment and organic material was demonstrated by a $1 \mathrm{~cm}$-thick layer of black, organic-rich sediment with a significantly higher proportion of fines. The organic matter in this layer appeared to be of terrestrial origin and had elevated arsenic concentrations. 
Pull and Be Damned Flat, cut off from Skagit delta by the Swinomish channel jetty, was a lower energy environment than the delta front, as evidenced by sediments that were about equal parts sand and mud. Eelgrass beds have persisted at PBD for many years, so they do not appear to be adversely affected by the high mud content. The open exchange of water between PBD and Skagit Bay may prevent sediments from becoming highly reducing.

Lone Tree Lagoon, a small, shallow pocket estuary used as nursery habitat by juvenile salmon, had a few small, isolated patches of eelgrass. Sediments were strongly reducing in the LTL eelgrass beds, but no more so than in other protected eelgrass beds. Despite a relatively high proportion of mud, bottom sediments were poorly sorted and contained gravel and pebbles washed over from an adjacent cobble beach at high tide. Large grains would facilitate pore water-bottom water exchange and could have prevented toxic levels of sulfides from accumulating in eelgrass root zone sediments.

\section{Acknowledgments}

I thank Eric Aguilar for his help processing samples and measuring sediment grain size.

\section{References Cited}

Connell, W.E., and Patrick, W.H., 1967, Sulfate reduction in soil: effects of redox potential and pH: Science, v. 159, p. 86-87.

Devai, I., and DeLaune, R.D., 1995, Formation of volatile sulfur compounds in salt marsh sediments as influenced by soil redox condition: Organic Geochemistry, v. 23, no. 4, p. 283287.

Koch, E.W., 2001, Beyond light: physical, geological, and geochemical parameters as possible submersed aquatic vegetation habitat requirements: Estuaries, v. 24, no. 1, p. 1-17.

Mortvedt, J.J., 1996, Heavy metal contaminants in inorganic and organic fertilizers: Fertilizer Research, v. 43, p. 55-61.

Otero, N., Vitoria, L., Soler, A., and Canals, A., 2005, Fertilizer characterization: major, trace and rare earth elements: Applied Geochemistry, v. 20, p. 1473-1488.

Terrados, J., and others, 1999, Are seagrass growth and survival constrained by the reducing conditions of the sediment? Aquatic Botany, v. 65, p. 175-197. 


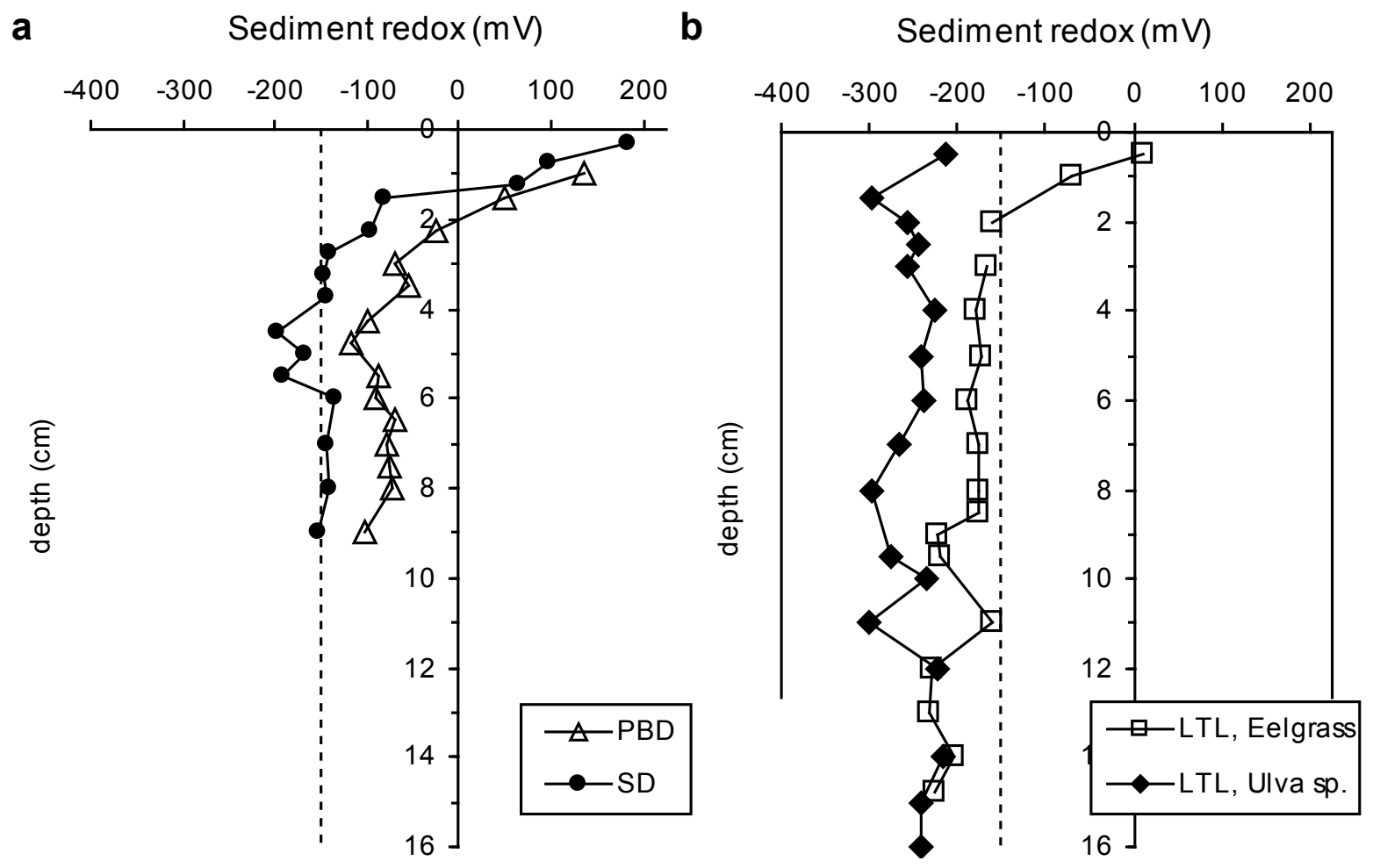

Figure 1. Downcore sediment redox profiles from (a) Pull and Be Damned Flat (PBD) and the Skagit delta (SD), and (b) from two sites in Lone Tree Lagoon (LTL) with eelgrass and macroalgae (Ulva sp.). Dashed line shows the redox value at which sulfides are produced. 


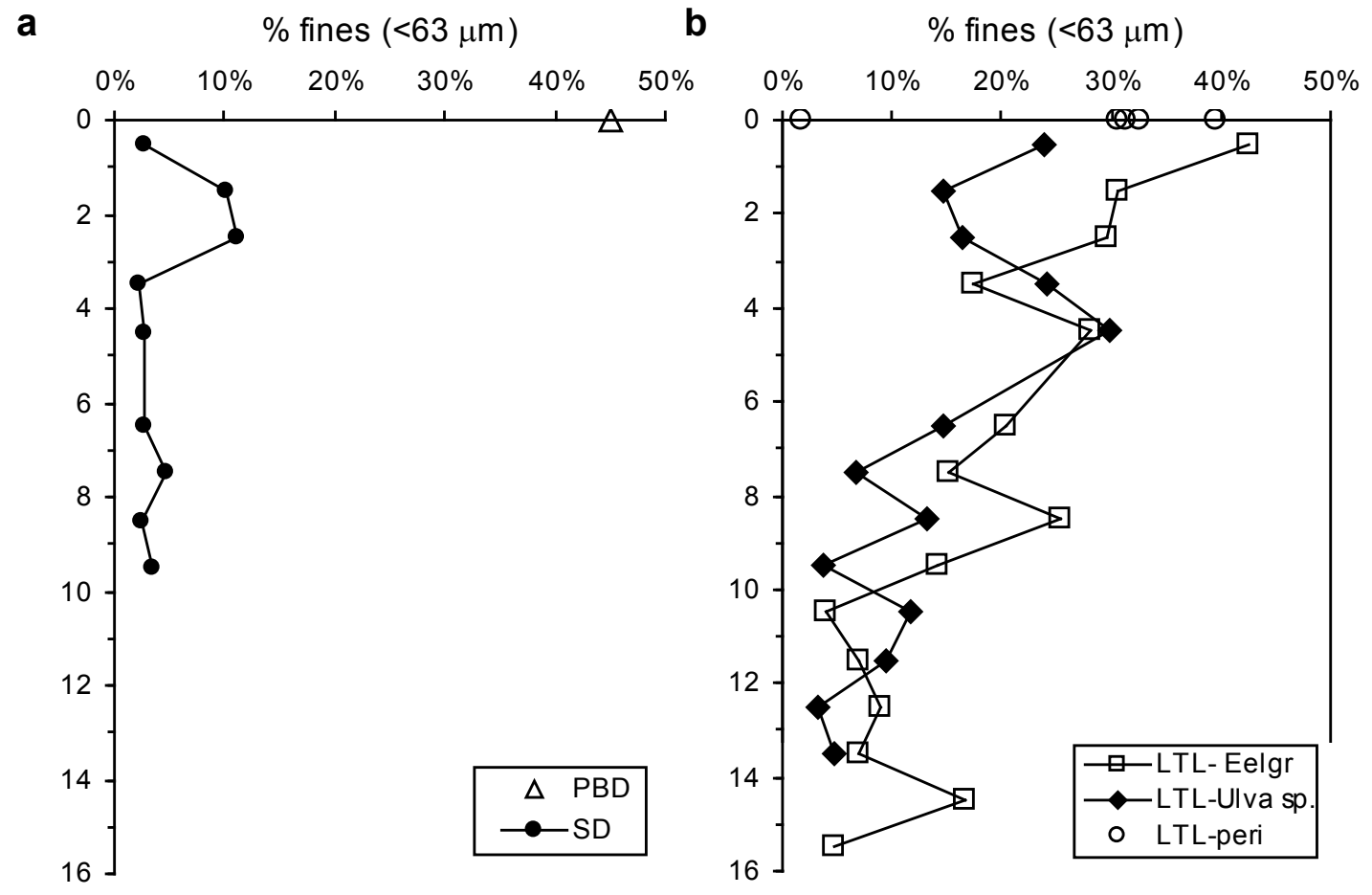

Figure 2. Downcore sediment grain size ( percent fines, dry weight) in (a) SD and PBD, and (b) LTL. Sediment samples in LTL were collected from an eelgrass bed (open squares), a macroalgae bed (filled diamonds) and around the perimeter of the lagoon (open circles).

Table 1. Average sedimentary metal concentrations ( $\mathrm{ppm}$ ) in the fine fraction by sampling location. Washington State Sediment Quality Standards (WA SQW) are shown for comparison.

\begin{tabular}{lcccccc}
\hline \multicolumn{1}{c}{ Sample } & Cadmium & Chromium & Copper & Nickel & Zinc & Arsenic \\
\hline SD (n=6) & 0.2 & 108 & 33 & 53 & 92 & 7 \\
PBD (n=8) & 0.6 & 167 & 39 & 80 & 87 & 8 \\
LTL (n=6) & 0.2 & 142 & 45 & 70 & 160 & 8 \\
WA SQS & 5 & 260 & 390 & N/A ${ }^{1}$ & 410 & 57 \\
\hline
\end{tabular}

${ }^{1} \mathrm{~N} / \mathrm{A}=$ not regulated 


\title{
Organic Matter Composition of Sediment in Nearshore Ecosystems of Puget Sound, Washington
}

\author{
By Robert J. Rosenbauer ${ }^{1}$, Eric Grossman², and Renee Takesue²
}

\begin{abstract}
Sedimentary organic matter (SOM) is of geochemical interest, because it is an integrator of processes both within drainage basins and at the continental margins, and because it is ultimately preserved in the geological record. The relationship between marine and terrestrially derived organic matter (OM) in sediment cores can be used to indicate the degree to which land use changes have impacted the pattern of nearshore environmental processes and marine biogenic productivity in an area. Biomarkers are ideal tools to assess the health of an ecosystem and the degree to which it has been influenced by terrestrial and anthropogenic inputs (Parrish and others, 2000). We examined three classes of biomarkers (aliphatics, polycyclic aromatic hydrocarbons (PAHs), and sterols) from surficial sediment and sediment cores from Westcott Bay (WB 1), Padilla Bay (Padilla v1 and Refinery), and from several other embayments in the San Juan Islands and Central Sound. We used sterol biomarkers (Volkman, 2005) to apportion inputs to ecosystems, with specific sterols assigned to different source organisms or categories: $\beta$-sitosterol to higher plants (Matsumoto and others, 2001) and brassicasterol to diatoms (Jeng and Huh, 2001). The aliphatic fraction helps distinguish aquatic from terrestrial input, because aquatic planktonic and benthic organisms synthesize hydrocarbons clearly distinguishable from the hydrocarbons found in the surface waxes of higher plants (Parrish and others, 2000). We used PAHs and $5 \beta$-stanols such as coprostanol to determine pollutant loading from oil spillage and sewage respectively (Chou and Liu, 2004). We examined the phenanthrene/ methylphenanthrene ratio as an indicator of wood burning (Yunker and others, 2002).

Major biomarker contributions in sediment samples were sterols and triterpenoids (sitosterol, campesterol, lupenone), derived mainly from vegetation. Also present were $n$-alkanes from epicuticular plant wax and phyto- and zooplankton, including diatoms, cyanobacteria, and dinoflagellates. Combustion sourced PAHs were ubiquitous. Petrogenic PAHs, as well as hopane and thiophene biomarkers indicative of petroleum, occurred at isolated sites. Sterols due to biohydrogenation processes (coprostanol, epicoprostanol), indicative of either sewage or bacterial degradation occurred in sediments from the Refinery site and Westcott Bay.
\end{abstract}

Key Words: biomarkers, sedimentary organic matter, hydrocarbons

1U.S. Geological Survey, 345 Middlefield Road, Menlo Park, CA 94025, brosenbauer@usgs.gov

2U.S. Geological Survey, Western Coastal and Marine Geology Program, Pacific Science Center, 400 Natural Bridges Dr., Santa Cruz, CA 95060 


\section{Sampling and Results}

We sampled two sites in Padilla Bay by vibra-coring: Padilla (v1) and March's Point offshore the refinery (fig. 1) and one site each in Westcott Bay (fig. 2) and Liberty Bay (fig. 3).

\section{Padilla Bay}

Surface sediment from Padilla Bay v1 contained about 1 percent organic carbon (OC). Sediment below $2 \mathrm{~cm}$ averaged $<0.3$ percent OC, presenting analytical challenges. Higher-plant sterols ( $\beta$-sitosterol, stigmasterol, campesterol) dominate the OC of this core (fig. 4a); a downcore peak in concentration at $5-6 \mathrm{~cm}$ (fig. $4 \mathrm{~b}$ ) coincides with a slight maximum in the concentration of cholesterol, which likely derives from either zooplankton or phytoplankton. The distribution of $n$-alkanes (fig. 4c) in the Padilla v1 core suggests some variability in the ratio of marine and terrestrial input to the sediment. For example, from the surface to about $8 \mathrm{~cm}$ depth, the distribution of $n$-alkanes with an odd-over-even carbon number preference (OEP) and a maximum at $n \mathrm{C}_{19}$ is characteristic of phytoplankton and some seagrasses (Botello and Mandelli, 1978). The downcore profiles of the $n \mathrm{C}_{17}$ and $n \mathrm{C}_{19} n$-alkanes are similar to the pattern of higherplant sterols and, in combination with the absence of a significant maximum in either the $n \mathrm{C}_{27}$ or $n \mathrm{C}_{29} n$-alkane, which are derived from terrigenous sources (Eglinton and Hamilton, 1963), suggest both the sterols and $n$-alkanes are from seagrass. At $8 \mathrm{~cm}$ depth, there is a transition to $n$ alkanes with an OEP and maxima at $n \mathrm{C}_{19}$ and $n \mathrm{C}_{29}$, the latter derived from vascular terrigenous plants. Below $8 \mathrm{~cm}$, the $n$-alkane pattern has an OEP with a maximum at $\mathrm{C}_{25}$, a compound that has been attributed to macro-algae (Nunez and others, 2002). The total PAH (TPAH) concentration at this site increased from 13 to $29 \mathrm{ng} / \mathrm{g}$ (dry sediment) from the surface to the base of the core (fig. 5A). The ratio between the alkyl-substituted PAHs and the parent PAHs, as well as the ratio between fluoranthene and fluoranthene plus pyrene, indicates that these are all combustion derived PAHs. The similar downcore patterns of TPAH and the $n$-alkane $n \mathrm{C}_{29}$ suggest that the PAHs are related to the terrigenous input $\left(\mathrm{R}^{2}=0.7\right)$ (fig. 5).

\section{March's Point Refinery Site}

The upper $4 \mathrm{~cm}$ of OM in sediment from the Padilla Refinery core (fig. 1) is characterized by petrogenic hopanes and a mixture of petroleum and combustion derived PAHs. The TPAH ranges from over $100 \mathrm{ng} / \mathrm{g}$ (in the upper $4 \mathrm{~cm}$ ) to about $50 \mathrm{ng} / \mathrm{g}$ (below $4 \mathrm{~cm}$; fig. 6). The presence of thiophenes may indicate trace petroleum in the sediments to the base of the core at $50 \mathrm{~cm}$. The complex mixture of sterols contains biomarkers for sewage/bacterial degradation, fungi/decaying plant matter, diatoms/dinoflagellates, and zooplankton. The $n$-alkane OEP pattern with maxima at $n \mathrm{C}_{17}$ and $n \mathrm{C}_{27}$ are markers for phytoplankton and higher-plants that are chemically distinct from the terrigenous OC in Padilla v1 core (fig. 7). The presence of highly branched isoprenoids (HBI) $\mathrm{C}_{20}$ and $\mathrm{C}_{25}$ also is indicative of diatoms (Volkman and others, 1994; Belt and others, 2000).

\section{Westcott Bay}

The absolute abundance and downcore variability of biomarkers in the sediment from the Westcott core (fig. 2) was greater than that of the Padilla v1 and Refinery cores. 
The $n$-alkanes typically exhibited a bimodal pattern and an OEP with maxima at $n \mathrm{C}_{17}$ or $n \mathrm{C}_{19}$ and $n \mathrm{C}_{27}$ or $n \mathrm{C}_{29}$, indicating a mix of marine and terrigenous input. The relationship between the predominance of $n \mathrm{C}_{17}$ or $n \mathrm{C}_{19}$ indicates a temporal shift in the marine component of the sediment in 1900 and again in 1980 (fig. 8A). There is a downcore maximum in the $n \mathrm{C}_{19} n$ alkane in 1960 that coincides with maxima in most of the sterols (fig. 9). There is also a spike in sterol concentrations in 1994. Some of these oscillations may be smoothed when these data are normalized to total organic carbon. Maxima in the downcore profile of $\mathrm{C}_{29} n$-alkane at 50 and 75 years ago indicate large increases of terrigenous input (fig. 8B). The TPAHs are high relative to even the Refinery site but are all combustion sourced (fig. 10).

\section{San Juan Island (SJI) and Central Sound Embayments}

Most of OM in sediment cores and surface samples from embayments in and around SJI and Central Sound is a variable mixture of marine and terrigenous-plant material. The sediment at Liberty Bay (fig. 3) is noteworthy, because anthropogenic, marine, and terrigenous signals are all prominent. The anthropogenic signal is a large unknown compound mixture (UCM), steranes and hopanes associated with petroleum, and a mixture of biodegraded and combustion sourced PAHs (fig. 11). The terrigenous signal is an OEP with $\mathrm{C}_{\max }$ at $n \mathrm{C}_{27}$. The marine signal is evident in the $n$-alkane OEP with $\mathrm{C}_{\max }$ at $n \mathrm{C}_{19}$ and sterols with diagenetic derivatives.

\section{Conclusions}

Preliminary analysis of downcore profiles reveals a complex pattern of hydrocarbons, in terms of history and compound distribution. All nearshore sediments contain detectable sterol, alkane, and PAH compounds, but there are differences among sites and among sediment depths within sites. The predominant signal in alkanes likely derives from natural sources that include algae (e.g., $n \mathrm{C}_{17}$ ), marine seagrass (e.g., $n \mathrm{C}_{19}$ ), and terrestrial plant waxes (e.g., odd carbon alkanes between $n \mathrm{C}_{23}$ and $n \mathrm{C}_{33}$ ). In the Refinery and Liberty Bay sediments, petroleum has also contributed alkanes. Both algal alkanes and sterols show some diagenetic loss over time. The sterols indicate widespread but variable higher-plant input at all sites, as well as input from planktonic algae, zooplankton, fungi, decaying plant matter, and bacterial degradation. PAHs in the sediments derive from both natural and anthropogenic sources. Combustion PAHs, derived from aeolian transport, predominate in the sediments; some sediment intervals near the March Point Refinery and surface sediment in Liberty Bay also show clear PAH contamination, probably from both combustion and petroleum inputs.

Using stable isotope analyses and multivariate techniques (Principal Components Analysis), we are currently preparing a detailed assessment of hydrocarbons in the Puget Sound sediments, in the context of local and regional sources and pathways.

\section{Acknowledgments}

We would like to acknowledge Aaron Powers, for his help in carrying out the laboratory analyses, Elena Nilsen, who helped develop the analytical procedures, and Fran Hostettler who helped with the mass chromatography. 


\section{References Cited}

Belt, S.T., Allard, G., Massé, G.A., Robert, J-M, and Rowland, S., 2000, Important sedimentary sesterterpenoids from the diatom Pleurosigma Intermedium: Chemical Communications, $\mathrm{p}$. 501-502.

Botello, A.V., and Mandelli, E.F., 1978, Distribution of n-paraffins in sea-grasses, benthic algae, oysters and recent sediments from Terminos Lagoon, Campeche, Mexico: Bulletin of Environmental Contamination and Toxicology, v. 19, no. 2, p. 162-170.

Chou, C-C., and Liu, Y-P., 2004, Determination of fecal sterols in the sediments of different wastewater outputs by GC-M: International Journal of Environmental and Analytical Chemistry, v. 84, no. $5 / 15$, p. 379-388.

Eglinton, G., and Hamilton, R.J., 1963, The distribution of alkanes, in Swain, T. (ed.), Chemical Plant Taxonomy: Academic Press, New York, p. 187-218.

Jeng, W.L., and Huh, C.A., 2001, Comparative study of sterols in shelf and slope sediments off northeastern Taiwan: Applied Geochemistry, v. 16, p. 95-108.

Matsumoto, K., Yamada, K., and Ishiwatari, R., 2001, Sources of 24-ethylcholest-5-en-3beta-ol in Japan Sea sediments over the past 30,000 years inferred from its carbon isotopic composition: Organic Geochemistry, v. 32, no.2, p. 259-269.

Nunez, R., Spiro, B., Pentecost, A., Kim, A., and Coletta, P., 2002, Organo-geochemical and stable isotope indicators of environmental change in a marl lake, Malham Tarn, North Yorkshire, UK: Journal of Paleolimnology, v. 28, p. 403-417.

Parrish, C.C., Abrajano, T.A., Budge, S.M., Helleur, R.J., Hudson, E.D., Pulchan. K., and Ramos, C., 2000, Lipid and Phenolic Biomarkers in Marine Ecosystems: Analysis and Applications: The Handbook of Environmental Chemistry, Marine Chemistry: Springer Berlin / Heidelberg (pub) Volume 5D/2000, chapter 8, p. 193-223.

Volkman, J.K., Barratt, S.M., and Dunstan, G.A., 1994, C[25] and C[30] highly branched isoprenoid alkenes in laboratory cultures of two marine diatoms: Organic Geochemistry, v. 21, p. 407.

Volkman, J.K., 2005, Sterols and other triterpenoids: source specificity and evolution of biosynthetic pathways: Organic Geochemistry, v. 36, p. 139-159.

Yunker, M.B., Macdonald, R.W., Vingarzanc, R., Mitchelld, H., Goyettee, D., and Sylvestrec, S., 2002, PAHs in the Fraser River basin: a critical appraisal ratios as indicators of PAH source and composition Organic Geochemistry, v. 33 p. 489-515. 


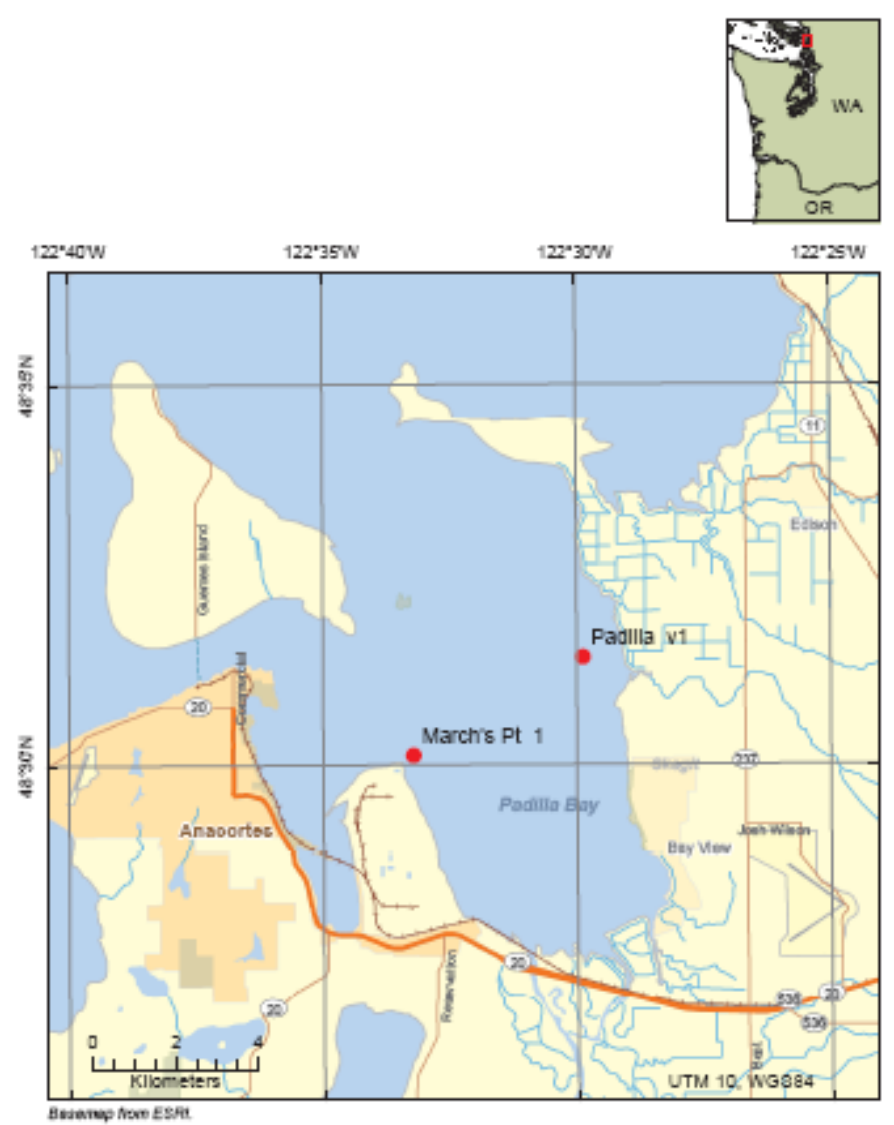

Figure 1. Surface and sediment core locations in Padilla Bay. 


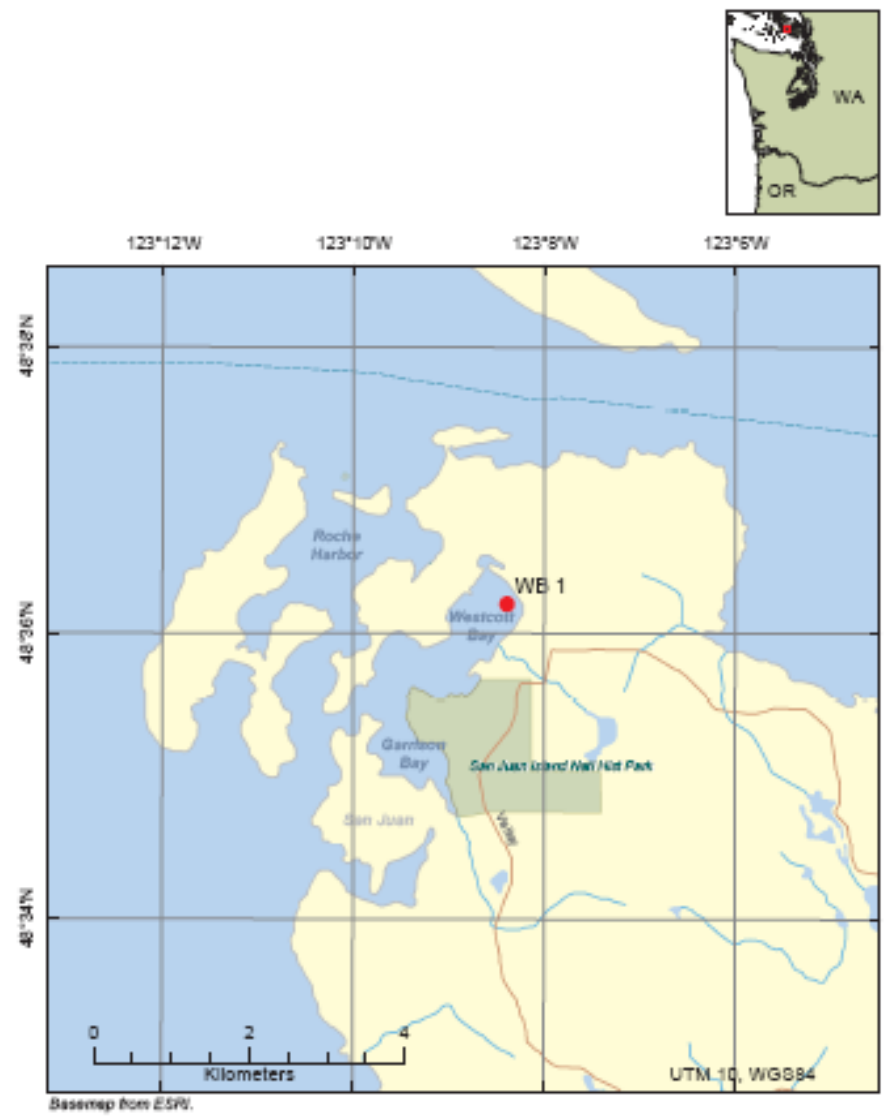

Figure 2. Sediment core location in Westcott Bay. 

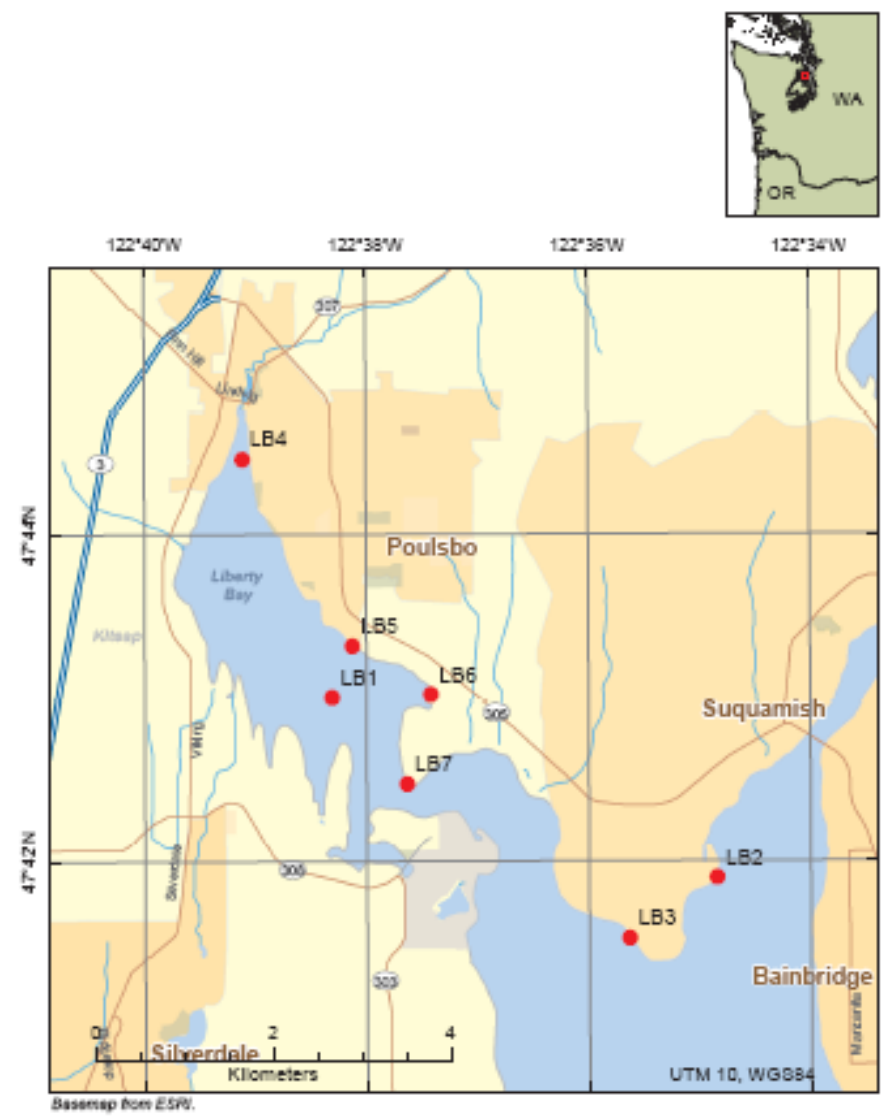

Figure 3. Location map of surface sediment samples from Liberty Bay. 


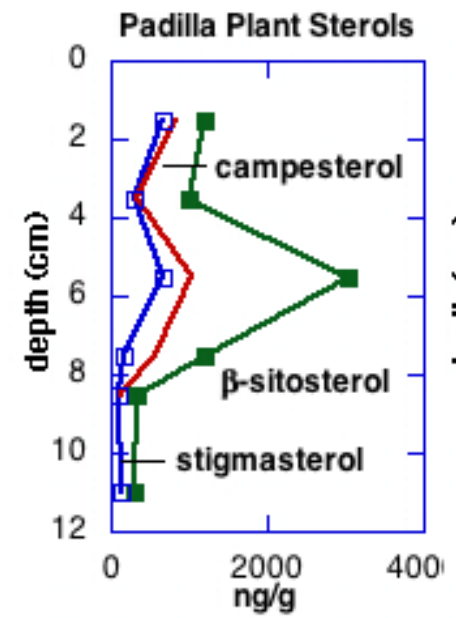

A

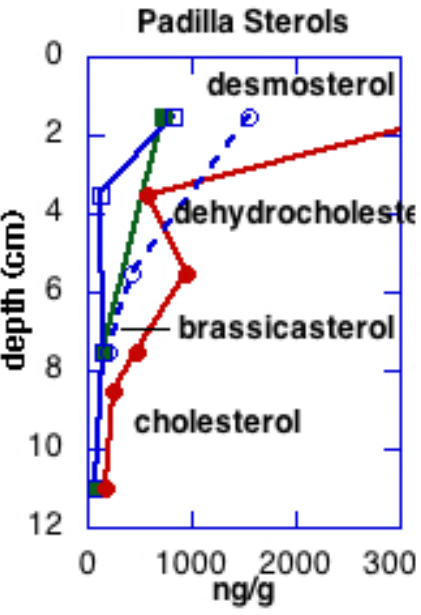

B

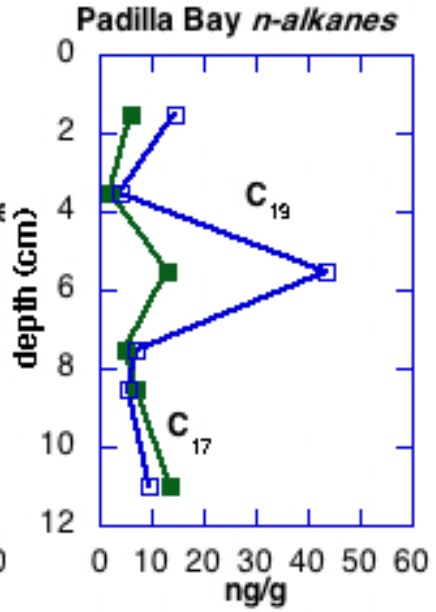

C

Figure 4. Concentrations of higher-plant sterols (4A), other diagnostic sterols (4B), and low-molecular weight $n$-alkanes $\left(n \mathrm{C}_{17}, n \mathrm{C}_{19}\right)(4 \mathrm{C})$ extracted from core $\mathrm{v} 1$ versus depth.

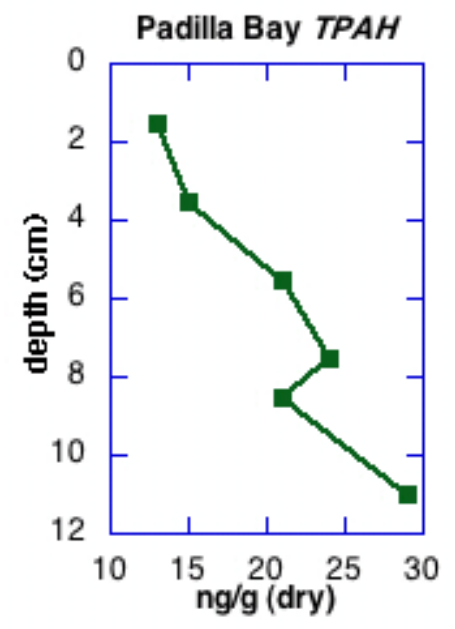

A

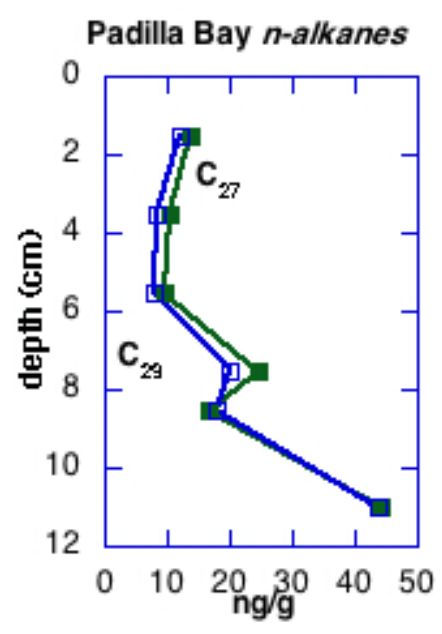

B

Figure 5. Concentrations of total polycyclic aromatic hydrocarbons $(5 \mathrm{~A})$ and the high-molecular weight $n$ alkanes $\left(n \mathrm{C}_{27}\right.$ and $\left.n \mathrm{C}_{29}\right)(5 \mathrm{~B})$ extracted from sediment core $\mathrm{v} 1$ plotted versus depth. 

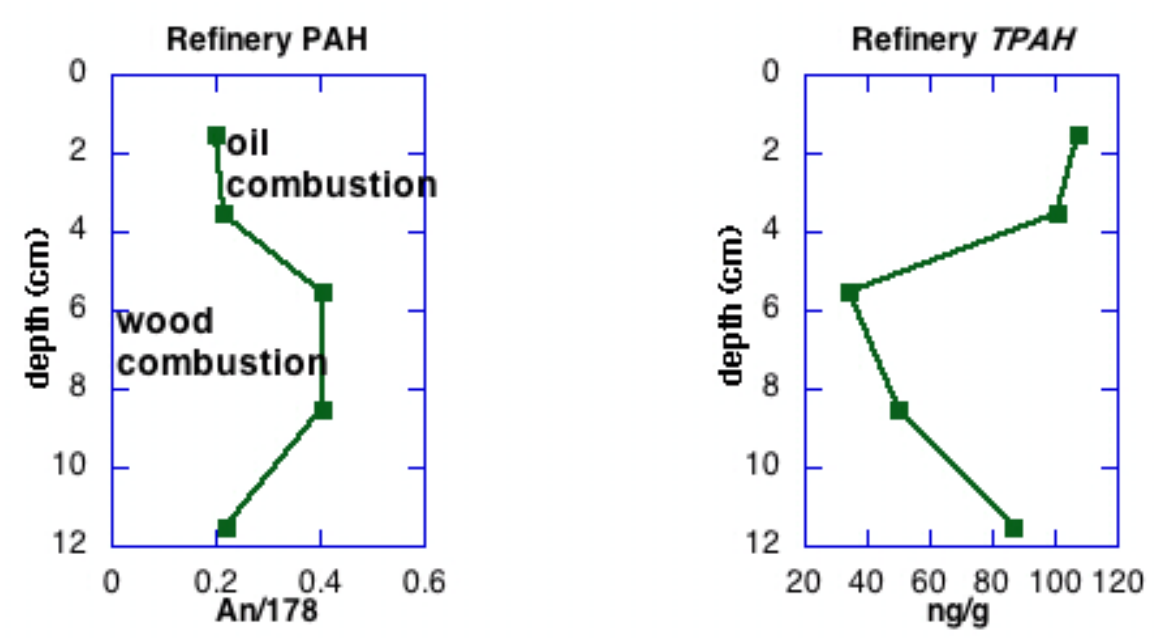

Figure 6. Ratio of anthracene to anthracene plus phenanthrene (An/178) and TPAH extracted from the sediment core at March's Point plotted versus depth. The An/178 is on the cusp of petrogenic versus pyrogenic sourced PAHs but indicates mostly pyrogenic PAHs.
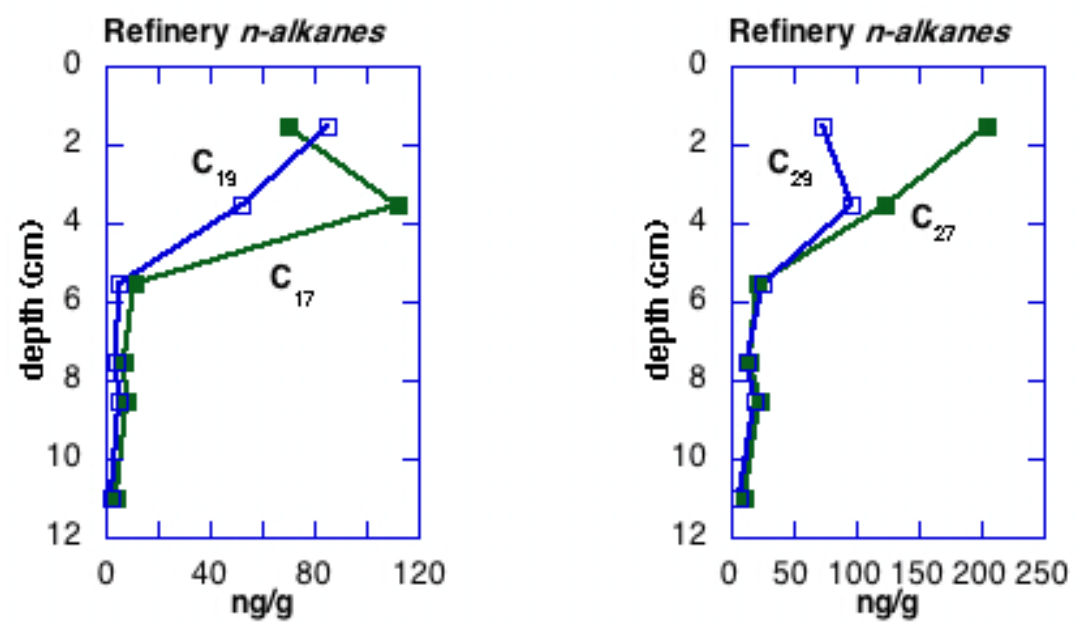

Figure 7. Concentrations of low-molecular weight n-alkanes ( $\mathrm{nC} 17$ and $\mathrm{nC} 19)(7 \mathrm{~A})$ and the high-molecular weight n-alkanes (nC27 and nC29) (7B) extracted from the sediment core at March's Point plotted versus depth. 


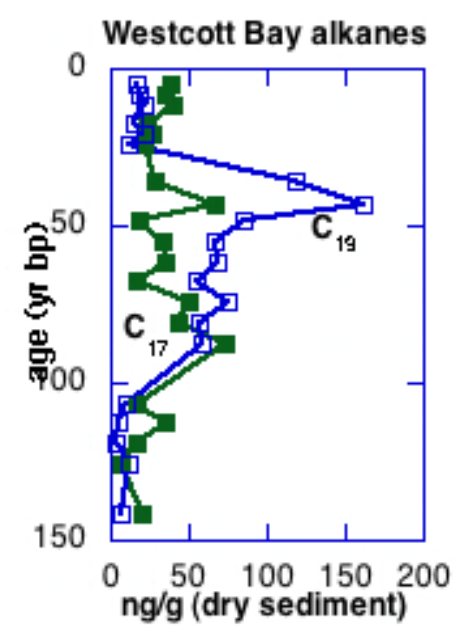

A

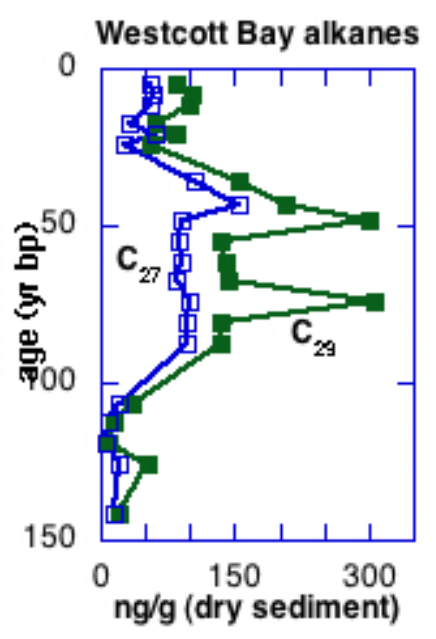

$\mathrm{B}$

Figure 8. Concentrations of low-molecular weight n-alkanes ( $\mathrm{nC} 17$ and $\mathrm{nC} 19)(8 \mathrm{~A})$ and the high-molecular weight n-alkanes (nC27 and $\mathrm{nC29}$ ) (8B) extracted from sediment core v1 versus time. 
A
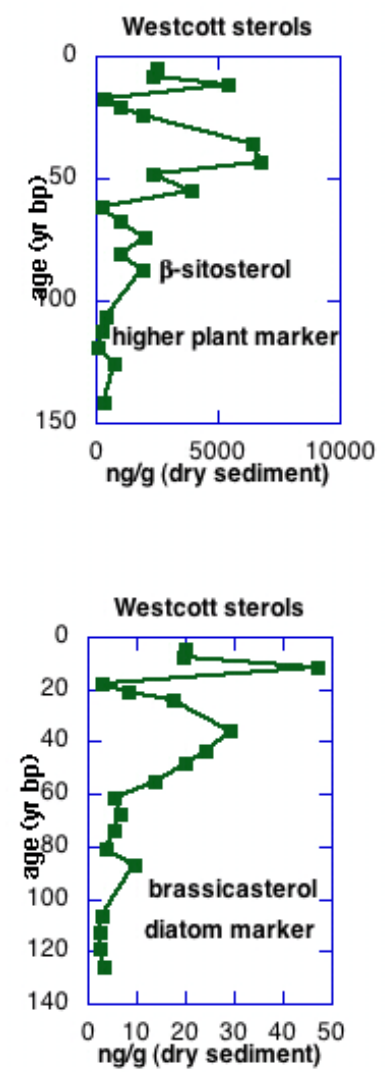

C
B
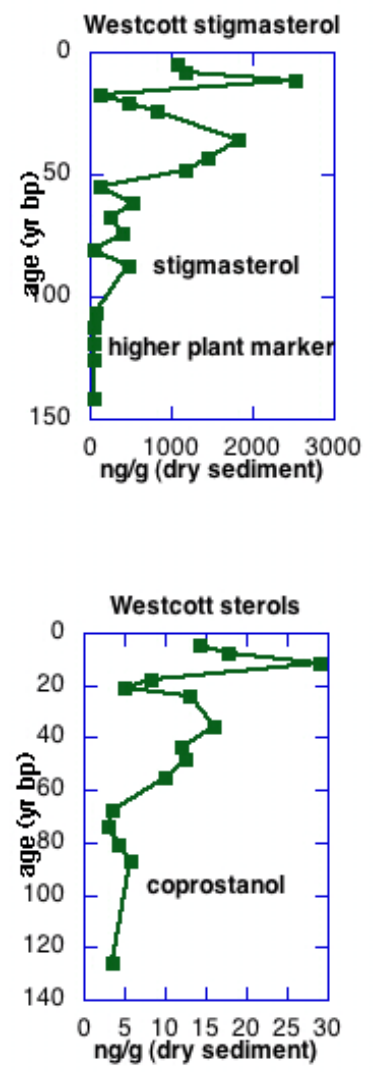

D

Figure 9. Concentration of sterols extracted from a sediment core in Westcott Bay, indicating higher plants $(A, B)$, diatoms $(C)$, and zooplankton (D). 


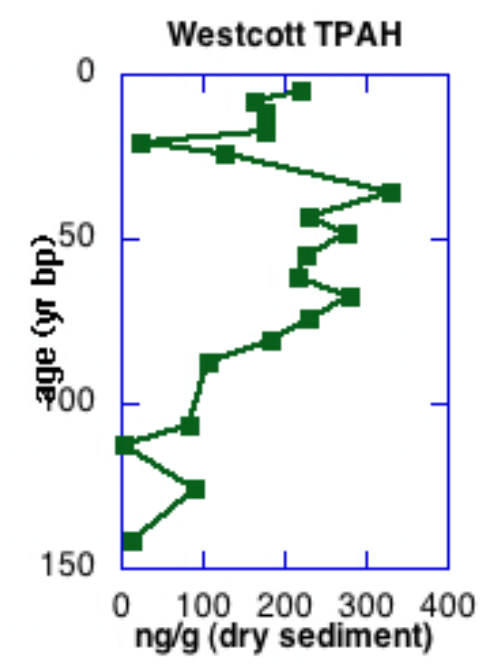

A

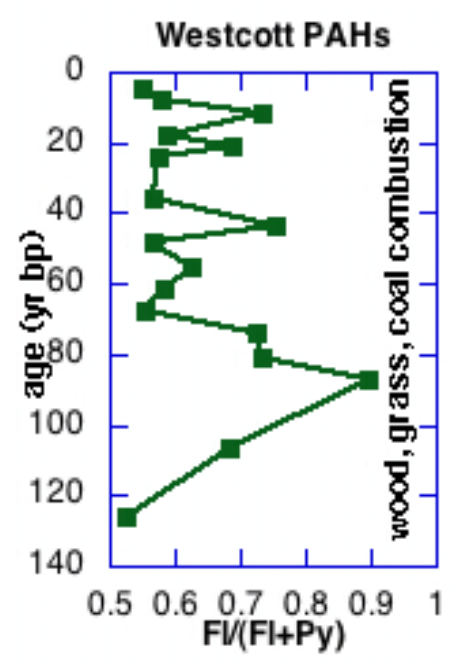

$\mathrm{B}$

Figure 10. Concentration TPAH extracted from a sediment core in Westcott Bay and the ratio of fluoranthene to fluoranthene plus pyrene indicating combustion sourced PAHs.

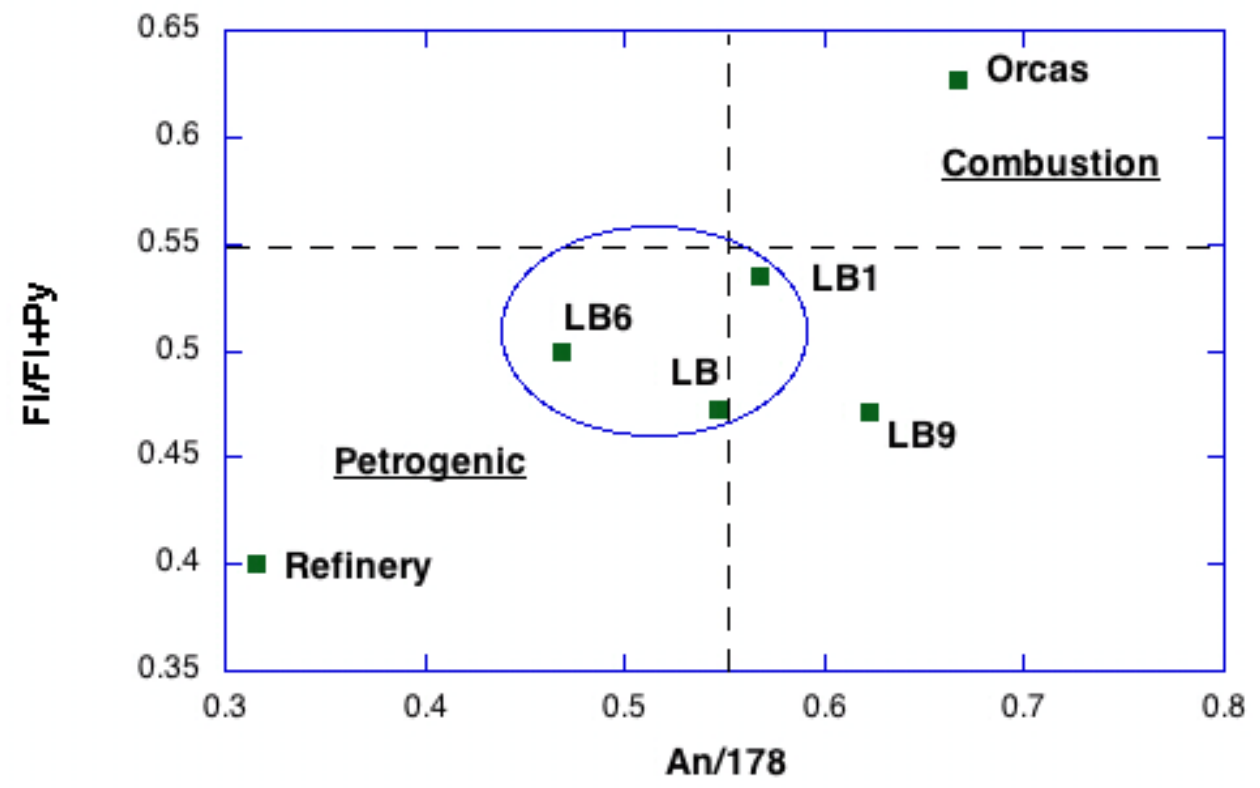

Figure 11. Plot of selective $\mathrm{PAH}$ ratios indicative of combustion versus petrogenic sources. A sample from the refinery site and samples from Liberty Bay enclosed within the oval are within or near the petrogenic field. All other samples (shown by Orcas Bay) from the SJI and central bays are in the combustion field. 


\title{
Habitat Use and Timing by Bull Trout in Marine Waters of Northern Puget Sound, Washington
}

\author{
By Reg Reisenbichler ${ }^{1}$, Mike Hayes², Steve Rubin², Fred Goetz 3 , and Mike Parsley ${ }^{4}$
}

\begin{abstract}
Bull trout (Salvelinus confluentus) and its habitats are protected under the U.S. Endangered Species Act. However, regulators and scientists know little about the habitats used by anadromous bull trout during their residence in marine waters. We used stationary receivers located in the lower Skagit River and mobile tracking equipment in marine waters to study the timing and habitat use for bull trout in Skagit Bay during April-August 2006. We surgically implanted acoustic tags in 50 bull trout. We captured 30 by beach seining or hook and line in Puget Sound during April 2004 to June 2006, and we captured the other 20 by hook and line in the lower Skagit River during March 13 to April 3, 2006. The fish were 22-56 cm fork length at tagging. Tagged fish moved past the stationary receivers toward Skagit Bay from March to May, and they returned to the river from mid-May to mid-August. While in Skagit Bay, fish typically resided within $300 \mathrm{~m}$ of the shoreline and at a depth $\leq 5 \mathrm{~m}$. Each fish tended to remain in a limited nearshore area, generally no more than $1.5 \mathrm{~km}$ in length. We monitored four fish continually for 20-24 hours, each on a different day at least one week apart. The only differences between diurnal and nocturnal habitat selection and behavior seemed to reflect changes in tidal height rather than solar position.
\end{abstract}

Key Words: Bull trout; acoustic telemetry; nearshore habitat use

\section{Further Work}

We will characterize other habitat features such as bathymetric topography, geomorphic shoreline forms, distance from shore, and distance from man-made structures or shoreline modifications. Most or all of these habitat data will be taken from existing data bases in collaboration with the Skagit River System (Tribal) Cooperative.

\section{Acknowledgments}

We thank Rae Mooney, Tiffany Anders, Curt Kraemer, Eric Jeanes, and Rich Henderson for their valuable project assistance. Rae and Tiffany deserve special recognition. They were Student Conservation Corps (SCA) volunteers who worked very long hours in both fair and foul weather, remaining alert, helpful, and pleasant. We thank SCA for helping acquire and support Rae and Tiffany.

1U.S. Geological Survey, Western Coastal and Marine Geology Program, Pacific Science Center, 400 Natural Bridges Dr., Santa Cruz, CA 95060; egrossman@usgs.gov

2U.S. Geological Survey, Seattle, WA

3U.S. Army Corps of Engineers, Seattle, WA

4U.S. Geological Survey, Cook, WA 


\title{
Historical Changes in Delta Sedimentary Environments
}

\author{
By Eric Grossman ${ }^{1}$
}

\section{Abstract}

Habitat restoration commonly aims to return environments and processes to conditions that predate extensive land use or that are thought to support ecosystem recovery. In many delta settings in Puget Sound, conversion of wetlands and marsh for agriculture, industry, and urban uses, through diking, shoreline armoring, and channelization of river flow has greatly altered nearshore sedimentation processes. To characterize the past distribution and function of habitats and to quantify the linkages and processes that alter nearshore ecosystems, the U.S. Geological Survey Coastal Habitats in Puget Sound (CHIPS) project on Restoration of Large River Deltas is reconstructing recent changes in nearshore habitats, ecosystem function and developing a sediment budget using geophysical, sedimentological, and geochemical approaches (fig. 1).

Key Words: habitat, nearshore, delta, Skagit River, salmon, eelgrass, mapping, seismic reflection, sediment, core, $14 \mathrm{C}, 210 \mathrm{~Pb}$

Initial studies are focused on the Skagit River Delta where diversion of the river toward Skagit Bay in the late 1800s and the later channelization of the river around Fir Island most likely increased discharge and sediment delivery across the delta and nearshore by focusing flow through fewer distributaries (fig. 2).

Using high-resolution seismic reflection profiling and analyses of sediment cores across the greater Skagit River delta, we are reconstructing how nearshore habitats have evolved in response to natural variability over the past several millennia, as well as human land-use activities over the last 150 years. High resolution seismic reflection (CHIRP) profiles reveal marked reflection surfaces that may be related to erosion or lithology, including Glacier Peak lahar deposits and recent sediments (fig. 3). These interpretations enable us to model sediment accumulation patterns prior to extensive land use and to compare rates and modes of accumulation operating over millennia to the patterns governing the last 150 years of human land use.

Sediments from cores reveal abrupt changes in sediment grain size, with significant coarsening offshore of channelized river flow. ${ }^{210} \mathrm{~Pb}$ and ${ }^{14} \mathrm{C}$ dating of sediment cores reveals that many of these abrupt changes began about 1850 . Sediment accumulation rates have generally increased by more than 10 times across extensive areas of the nearshore. These records help to quantify the regional sediment budget and the extent to which eelgrass (Zostera. marina), pocket estuaries and forage fish spawning sites change due to sediment impacts related to land use. They provide key criteria for developing restoration strategies, predicting outcomes, and recovering nearshore ecosystem health.

1U.S. Geological Survey, Western Coastal and Marine Geology Program, Pacific Science Center, 400 Natural Bridges Dr., Santa Cruz, CA 95060; egrossman@usgs.gov 


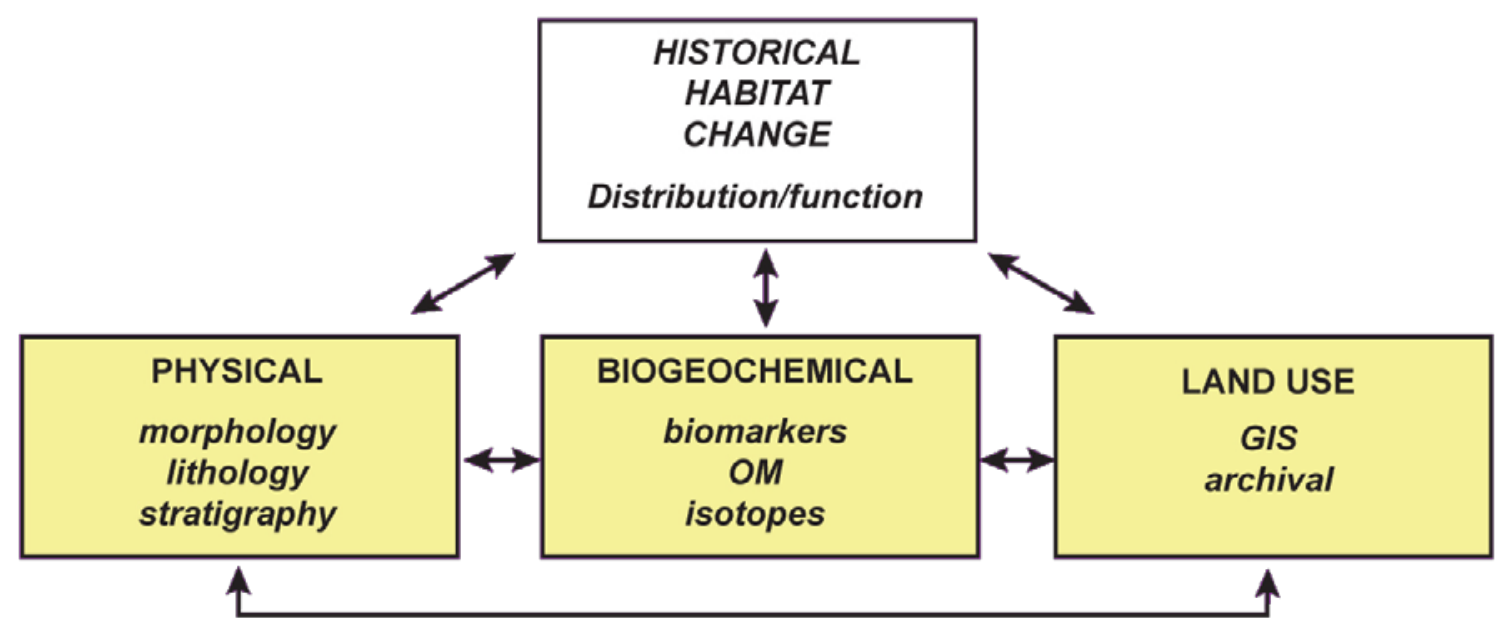

\section{Sediment Budget}

Figure 1. Conceptual model illustrating linkages between understanding physical and biogeochemical characteristics of habitat change and land use in order to reconstruct and predict change in habitats.

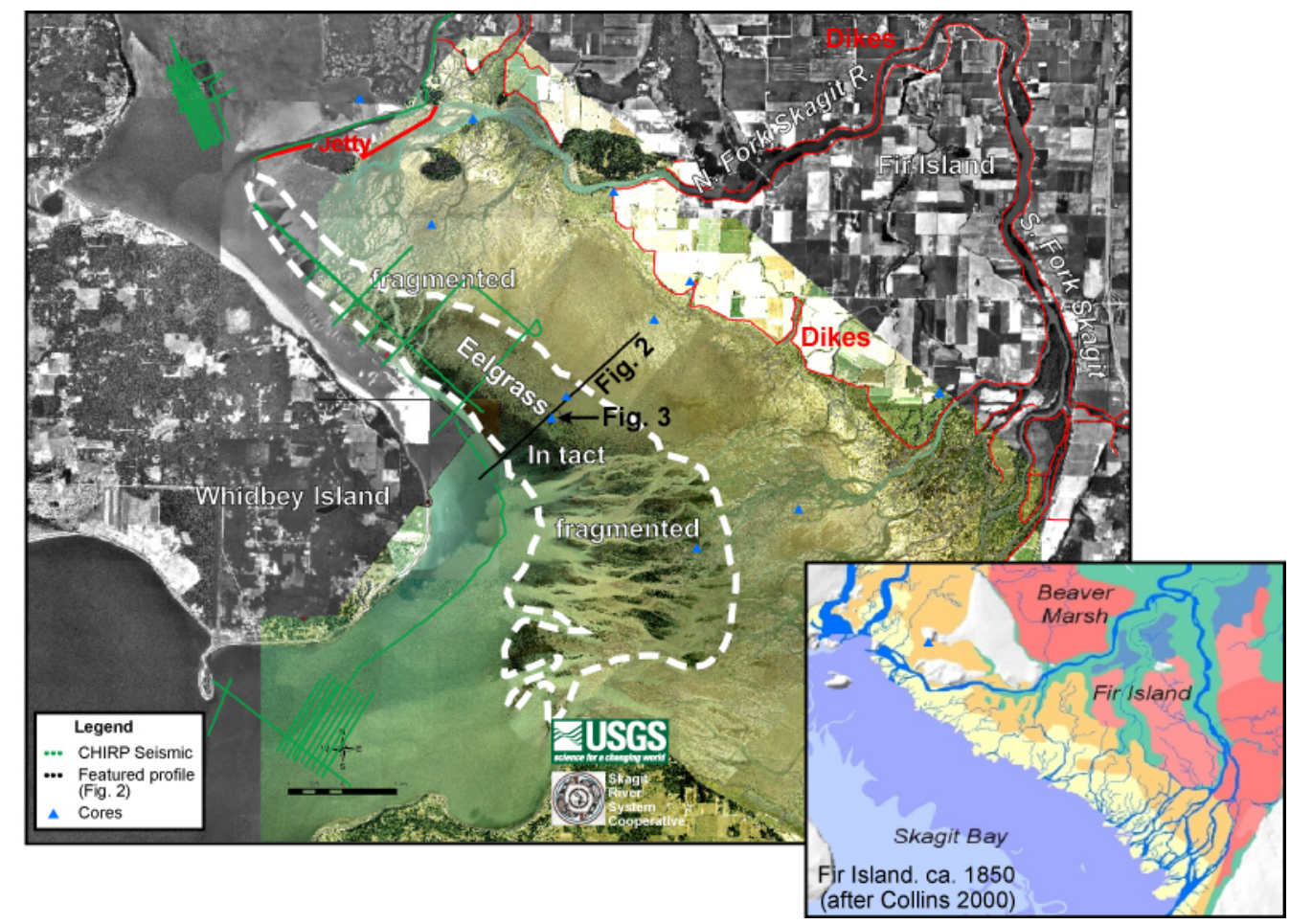

Figure 2. Map showing locations of seismic reflection data (green lines), featured profile (black line, fig. 3) and cores (blue triangles) across the modern Skagit Delta. Inset map shows extensive pre-historic distributaries network that discharged sediment more equitably across/along the delta. 


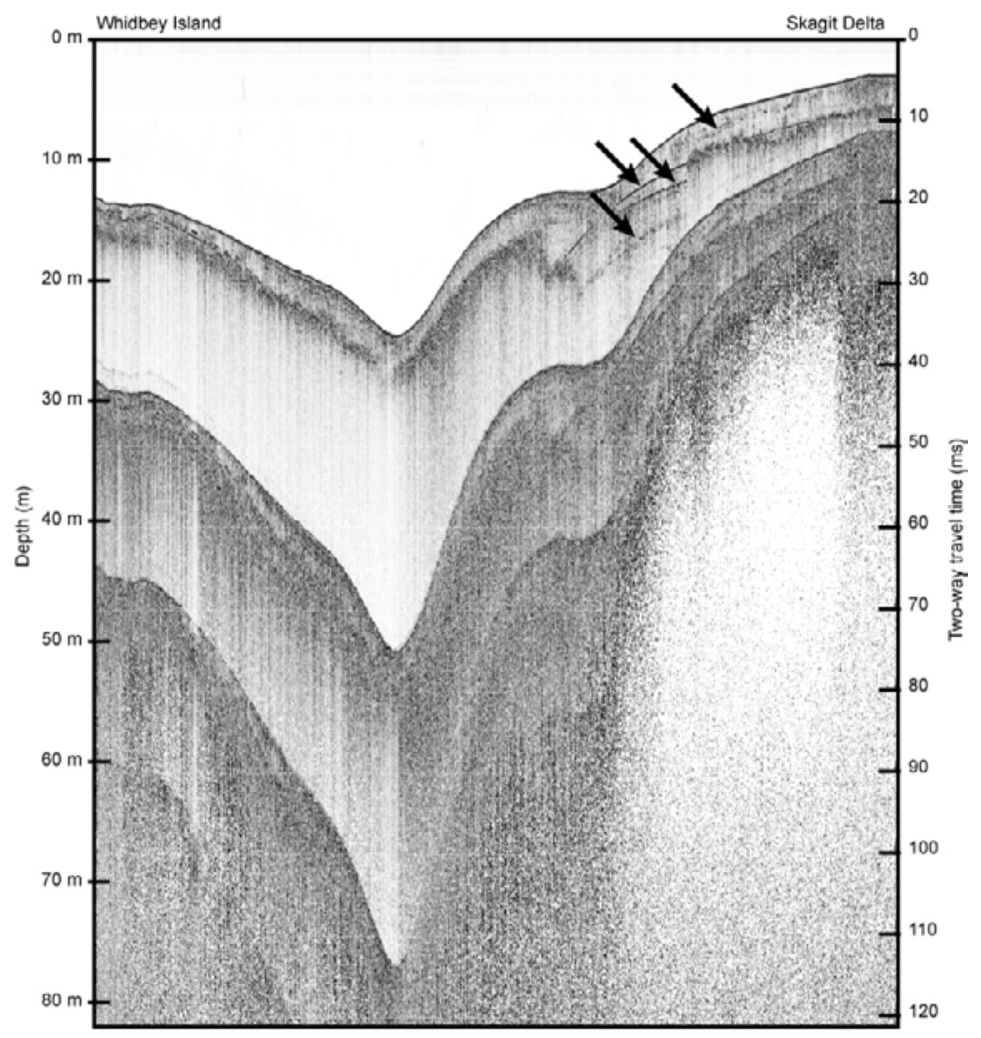

Figure 3. CHIRP seismic reflection profile along line SK05-1-4 showing reflection surfaces (arrows) interpreted as lithologic contacts and/or erosion surfaces associated with late Holocene sedimentation, including the last great Glacier Peak lahar deposits 1800-2300 yr BP. Cores (like that shown in fig. 4) that penetrate these surfaces, will help to establish their age and enable sedimentation rates to be calculated to quantify differences between natural variability and rates associated with land use activities. 

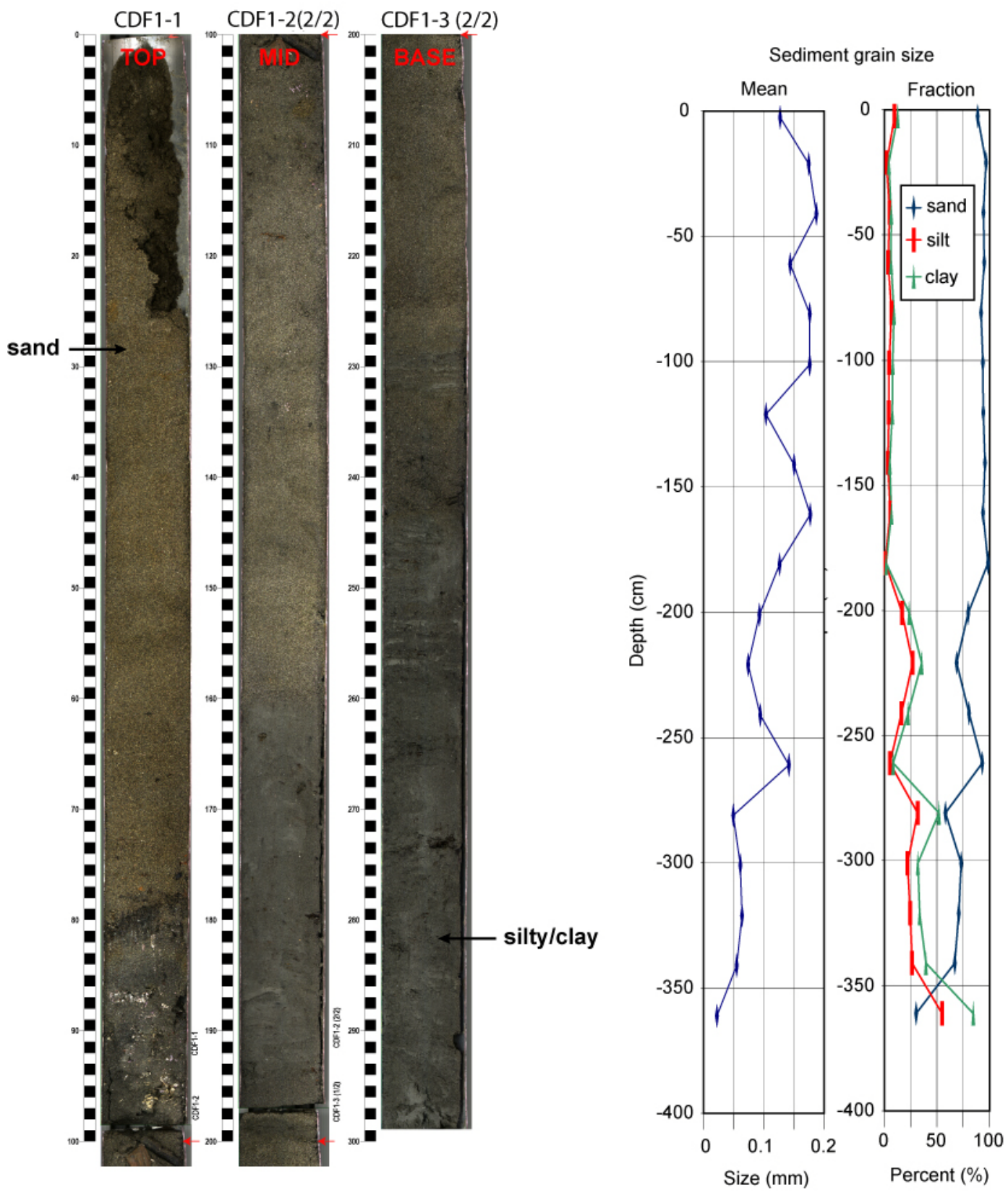

Figure 4. Interpreted core photograph and plots of mean sediment grain size and partitioning for core CDF1 at the central delta front (fig. 2). An abrupt change in lithology and grain size occurs at about $-275 \mathrm{~cm}$ depth with a coarsening upward sequence of fine to medium sands overlying silty-sandy clay. A similar upward coarsening sequence is found in most of the cores obtained across the Skagit Delta. The timing of this transition across the delta is being investigated through ${ }^{210} \mathrm{~Pb}$ and ${ }^{14} \mathrm{C}$ dating. 


\title{
Arrival and Expansion of the Invasive Foraminifer Trochammina hadai Uchio in Padilla Bay, Washington
}

\author{
By Mary McGann¹, Eric E. Grossman², Renee K. Takesue², and John P. Walsh ${ }^{3}$
}

\begin{abstract}
The earliest record in Puget Sound of Trochammina hadai Uchio, a benthic foraminifer common in Japanese estuaries, is from surface sediment collected in 1971 from Cornet Bay, March Point, Drayton Harbor, and Padilla Bay. The species, originally identified as Trochammina pacifica Cushman, was also recovered in high abundance (mean 55 percent) in nearly all of the 21 surface samples containing foraminifera obtained from Samish and Padilla bays in 1972-73 (Scott, 1974). To determine the timing of the arrival and expansion of the species in Padilla Bay, we analyzed the distribution of foraminifera in a $2.06 \mathrm{~m}$ core obtained in 2004 from the south-central portion of the bay. Trochammina hadai is absent from the lower 135 $\mathrm{cm}$ of the core, then first appears at $71-69 \mathrm{~cm}$, comprising $<1$ percent of the assemblage. Dating of these sediments by $\mathrm{Pb}-210$ suggests that this first appearance occurred about 1958. The species' appearance occurs stratigraphically well above changes seen in the sedimentology of the core at 171 and $92 \mathrm{~cm}$, possibly reflecting previous diversions of the Skagit River which impacted the deposition of sediments in the bay. Trochammina hadai was still rare (1 percent) at $62-60 \mathrm{~cm}$. By $52-50 \mathrm{~cm}$, however, its abundance increased dramatically to 58 percent. $\mathrm{Pb}-210$ dating suggests that this expansion occurred around 1972, consistent with the high abundances noted in the 1972-73 surface samples collected by Scott (1974). The species continues to dominate the assemblage (32-88 percent) to the top of the core.
\end{abstract}

Key Words: foraminifera, invasive, Padilla Bay, Trochammina hadai

\section{Introduction}

The common estuarine Japanese foraminifera Trochammina hadai Uchio was first identified as an invasive along the western coast of the United States in 1995, when it was discovered in sediments of San Francisco Bay (McGann and Sloan, 1996, 1999). Further sampling in Puget Sound (by the U.S. Geological Survey in 1997 and by the Washington State Department of Ecology and the Puget Sound Expedition in 1998) yielded nearly 50 sites where T. hadai was recovered (McGann and others, 1998). Since then, the species has been identified in recent sediments in 13 ports and estuaries from San Diego Bay to Prince William Sound (McGann and others, 2000).

1U.S. Geological Survey, Coastal and Marine Geology Team, MS 999, 345 Middlefield Road, Menlo Park, CA 94025; mmcgann@usgs.gov 2U.S. Geological Survey, Western Coastal and Marine Geology Program, Pacific Science Center, 400 Natural Bridges Dr., Santa Cruz, CA 95060

${ }^{3}$ East Carolina University, Department of Geology, Greenville, NC 
After these broad initial surveys, we re-examined detailed foraminiferal studies and archived sediment samples to determine the timing of $T$. hadai's first appearance on the west coast. We determined that the species was first recognized in Puget Sound in 1971 in samples collected from Cornet Bay, March Point, Drayton Harbor, and Padilla Bay (Penttila, Washington Department of Fish and Wildlife, written commun., 1998). A core collected in Padilla Bay in 2004 provided us the opportunity to refine our estimation of the species' arrival and expansion in the region.

\section{Early Studies}

Few researchers have documented the distribution of foraminifera in the central to northern portion of Puget Sound, including the Juan de Fuca and Georgia Straits. Cushman and Todd (1947) reported on the fauna recovered from 50 samples obtained in the San Juan Islands; six of 77 species recovered were dominant. In 1959 and 1960, sediment samples were taken in Bellingham and Samish bays to investigate the regional sedimentary and depositional history (Sternberg, 1967). Although foraminiferal tests were recovered, no detailed taxonomic analysis of the tests was conducted. Instead, Sternberg (1967) reported that the tests comprised 0-6 percent of the coarse fraction and that they were distributed similarly to the shell fragments, with higher concentrations in the central portions of both bays. Cockbain (1963) identified intertidal foraminifera from Oregon to Washington, including 175 sites from Juan de Fuca and Georgia Straits as well as the Fraser River. Smith $(1970,1978)$ reported on high latitude shallow-water foraminiferal faunas of British Columbia and southeast Alaska, and Lankford and Phleger (1973) investigated foraminifera of the nearshore turbulent zone of western North America, but only included taxonomic counts for one site near the Strait of Juan de Fuca.

In 1972-73, 23 surface samples were collected in Samish and Padilla bays to investigate the spatial distribution of nearshore foraminifera (Scott, 1974; fig. 1). Twenty-one of these samples recovered foraminifera; seventeen species were recognized. Scott (1974) identified the most abundant of these as Trochammina pacifica Cushman, but more recent sampling suggests the species was T. hadai (Sloan and McGann, 2000). The species was present in 20 of 23 samples, dominated 16 of them (26-100 percent), and was generally in high abundance throughout the region (mean 55 percent) (fig. 2). Shortly thereafter, a seasonal distribution study of foraminifera in the littoral zone of Samish Bay was conducted on samples collected in 197677 (Jones and Ross, 1979). Ten stations were sampled nine times over a 12-month period and $T$. pacifica (most likely $T$. hadai) formed the dominant part of the assemblage nearly all year long. In the same study, Jones and Ross (1979) analyzed several short cores from Samish Bay to determine the amount of seasonal variation in foraminiferal test preservation in the sediment column. Also in 1979, Gallagher reported on recent foraminifera from the shelf and slope of Vancouver Island. More than a decade later, Patterson and Cameron (1991) interpreted the depositional history of the Fraser Delta based on foraminifera and ostracods, and in 1998, Patterson and others published an atlas of common Quaternary benthic species for the western Canadian shelf. 


\section{Methods}

In 2004, we collected a $2.06 \mathrm{~m}$ core from the mudflat in the south-central portion of the bay (Padilla Flats $3 ; 48.48^{\circ} \mathrm{N}, 122.50^{\circ} \mathrm{W} ; 4.25 \mathrm{~m}$ water depth; fig. 3). Three distinct sedimentological units characterize this core: (1) medium to coarse sand from 206 to $171 \mathrm{~cm}$; (2) silt from 171 to $92 \mathrm{~cm}$, and (3) fine sand from $92 \mathrm{~cm}$ to the core top. The changes in core lithology most likely reflect past diversions of the Skagit River that impacted the deposition of sediments at the core site in Padilla Bay.

The core was sampled at $10 \mathrm{~cm}$ intervals for foraminiferal analysis. Sediment samples were wet-sieved through nested screens $(0.063 \mathrm{~mm}, 0.150 \mathrm{~mm}$, and $1.0 \mathrm{~mm})$ to segregate the size fractions. After air-drying the sediment, foraminifers were extracted from the $>0.150 \mathrm{~mm}$ size fraction. Each sample was split with a microsplitter into an aliquot containing at least 300 specimens. All specimens were picked and identified.

\section{Results and Discussion}

We recovered 12 species of foraminifera in the Padilla Flats 3 core, including Ammobaculites exiguus Cushman and Bronnimann, Ammonia beccarii (Linné), Buccella frigida (Cushman), Eggerella advena (Cushman), Elphidiella hannai (Cuhman and Grant), Elphidium frigidum Cushman, Haplophragmoides sp., Miliammina fusca (Brady), Trochammina inflata (Montagu), Trochammina macrescens Brady, Trochammina hadai, and Trochammina sp. All these species commonly reside in estuarine waters of the Pacific Northwest (Phleger, 1967, 1970; Scott, 1974; Jones and Ross, 1979; McGann and others, 1998)

The invasive foraminifer T. hadai is absent from the lower two-thirds of the core (206-71 $\mathrm{cm}$; fig. 4). The species first appears at $71-69 \mathrm{~cm}$, as a single test. A few centimeters higher (62$60 \mathrm{~cm})$, T. hadai comprises 1 percent of the assemblage. At $52-50 \mathrm{~cm}$, the species' abundance increases to 58 percent of the assemblage. Faunal dominance by $T$. hadai continues to the top of the core, accounting for 32-88 percent of the assemblage.

Sediment dating by $\mathrm{Pb}-210$ suggests that $T$. hadai first appears about 1958 . The expansion evident at $52-50 \mathrm{~cm}$ in the core dates at about 1972, coincident with the species' dominance noted in surface samples obtained by Scott (1974) in 1972-73 (fig. 2). Neither the arrival nor proliferation of $T$. hadai appears to be associated with the sedimentary changes noted at $171 \mathrm{~cm}$ and $92 \mathrm{~cm}$ in the core, suggesting that the species' presence was independent of past diversions and deposition by the Skagit River.

Prior to this study, the earliest record of T. hadai on the west coast of the United States was in 1971 at four sites in Puget Sound (Penttila, written commun., 1998). Evidence from the Padilla Flats 3 core places the species' arrival far earlier (about 1958) than previously suspected. It appears that it took about 14 years for T. hadai to proliferate in Padilla Bay. In San Francisco Bay, the species arrived between 1981 and 1983 and similarly expanded in about 12 years (McGann and others, 2000). It remains unclear whether T. hadai was introduced to different locations on the west coast through repeated inoculations directly from Japan or from a single invasive event followed by its spread among west coast ports by localized traffic. In either case, the vectors of introduction were likely ballast sediment, anchor mud, or in sediments associated with oysters imported for mariculture (McGann and others, 2000, 2003). 


\section{Conclusions}

A 2.06 m core, Padilla Flats 3, provides evidence of the timing of the arrival (about 1958) and proliferation (about 1972) of the invasive Japanese foraminifer T. hadai in Padilla Bay. The pattern is consistent with, but considerably earlier than the introduction of this invasive species in San Francisco Bay in 1981-83. Trochammina hadai was probably transported from Japan to western North America in ballast sediment, in anchor mud, or in sediments associated with oysters imported for mariculture. It is not clear whether the species was introduced to the west coast of the United States through a single or repeated inoculations.

\section{Acknowledgments}

We thank Melanie Moreno (U.S. Geological Survey), Daniel Penttila (Washington Department of Fish and Wildlife), James Carlton (Williams College and Mystic Seaport), Andrew Cohen (San Francisco Estuary Institute), and Roberto Llanso and Sandra Aasen (Washington State Department of Ecology) for providing samples for microfaunal analysis. Thanks also to Doris Sloan, Jere Lipps, and David Scott for helpful discussions related to this study.

\section{References Cited}

Cockbain, A.E., 1963, Distribution of foraminifera in the Juan de Fuca and Georgia straits, British Columbia, Canada: Cushman Foundation for Foraminiferal Research, v. 14, p. 37-57.

Cushman, J.A., and Todd, R., 1947, Foraminifera from the coast of Washington: Cushman Laboratory for Foraminiferal Research, Special Publication 21, p. 23.

Gallagher, M.T., 1979, Substrate controlled biofacies: recent foraminifera from the continental shelf and slope of Vancouver Island, British Columbia: Ph.D. thesis, University of Calgary, Calgary, Alberta, $232 \mathrm{p}$.

Jones, G.D., and Ross, C.A., 1979, Seasonal distribution of foraminifera in Samish Bay, Washington: Journal of Paleontology, v. 53, no. 2, p. 245-257.

Lankford, R.R., and Phleger, F.B., 1973, Foraminifera from the nearshore turbulent zone of western North America: Journal of Foraminiferal Research, v. 3, no. 3, p. 101-132.

McGann, M., Johengen, T.H., Reid, D.F., Ruiz, G.M., and Hines, A.H., 2003, Ballast sediment: a likely mechanism for nonindigenous foraminiferal introductions (abs.): Abstracts with Programs, 2003 Annual Meeting, Geological Society of America, v. 35, no. 6, p. 503.

McGann, M., and Sloan, D., 1996, Recent introduction of the foraminifer Trochammina hadai Uchio into San Francisco Bay, California, USA: Marine Micropaleontology, v. 28, p. 1-3.

McGann, M., and Sloan, D., 1999, Benthic foraminifers in the Regional Monitoring Program's San Francisco Estuary samples: 1997 Annual Report for the Regional Monitoring Program for Trace Substances in the San Francisco Estuary: San Francisco Estuary Institute, Richmond, CA, p. 249-258.

McGann, M., Sloan, D., and Cohen, A.N., 2000, Invasion by a Japanese marine microorganism in western North America: Hydrobiologia, v. 421, nos. 1-3, p. 25-30.

McGann, M., Sloan, D., and Llanso, R.J., 1998, Invasive Japanese foraminifer Trochammina hadai discovered in northern Puget Sound (abs.): Northwest Algal Symposium and Pacific Estuarine Research Society Joint Meeting, p. 30. 
Patterson, R.T., Burbidge, S.M., and Luternauer, J.L., 1998, Atlas of common benthic foraminiferal species for Quaternary shelf environments of western Canada: Geological Survey of Canada Bulletin 503, 91 p.

Patterson, R.T., and Cameron, B.E.B., 1991, Foraminiferal biofacies succession in the Late Quaternary sediments of the Fraser River delta, British Columbia: Journal of Foraminiferal Research, v. 21, p. 228-243.

Phleger, F.B., 1967, Marsh foraminiferal patterns, Pacific Coast of North America: Ciencia del Mary Limnologia Mexico, v. 1, p. 11-38.

Phleger, F.B., 1970, Foraminiferal populations and marine marsh processes: Limnology and Oceanography, v. 15, p. 522-534.

Scott, D.B., 1974, Recent benthonic foraminifera from Samish and Padilla bays, Washington: Northwest Science, v. 48, no. 4, p. 211-218.

Sloan, D., and McGann, M., 2000, New locales for Trochammina hadai, an invasive Japanese foraminifer, in the Strait of Georgia and Puget Sound (abs.): Abstracts with Programs, 2000 Cordilleran Meeting, Geological Society of America, v. 32, no. 6, p. A-68-69.

Smith, R.K., 1970, Late glacial foraminifera from southeast Alaska and British Columbia and a world-wide high northern latitude shallow-water faunal province: Archives des Sciences, v. 23, p. $675-702$.

Smith, R.K., 1978, Systematics of the North American high latitude very shallow cold water foraminiferal fauna: Archives des Sciences, v. 31, p. 133-162.

Sternberg, R.W., 1967, Recent sediments in Bellingham Bay, Washington: Northwest Science, v. 41, no. 2, p. 63-79. 


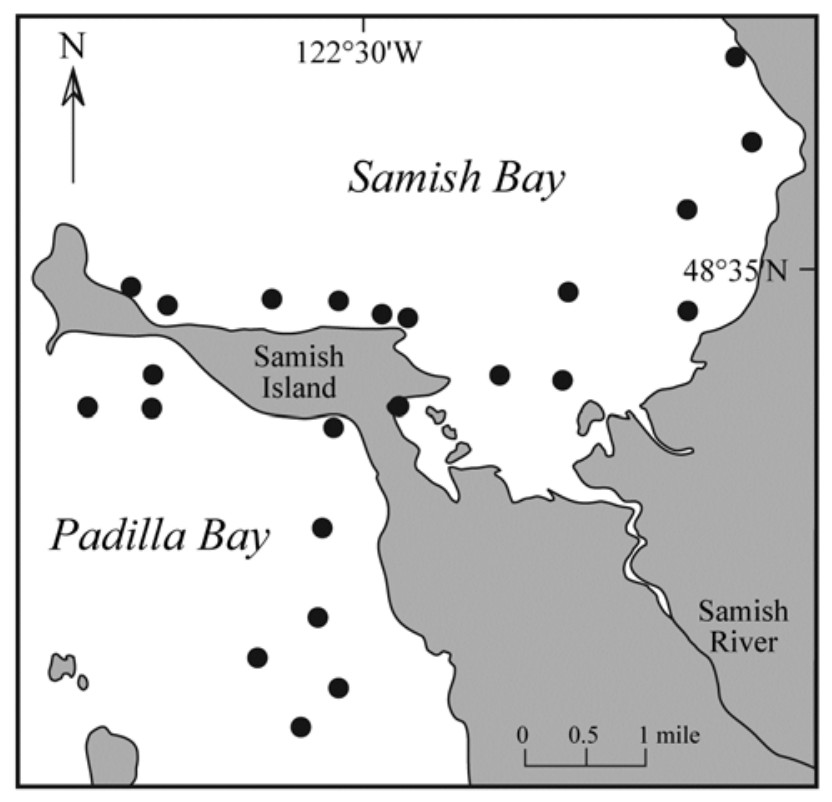

Figure 1. Location of samples collected in 1972-73 by Scott (1974) in Padilla and Samish Bays.

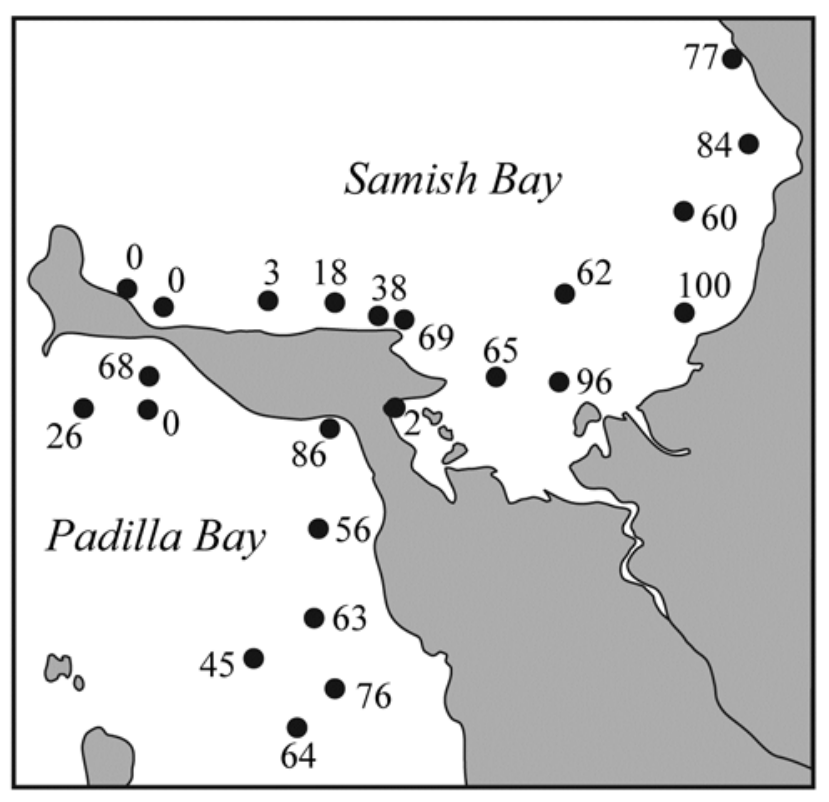

Figure 2. Percentage abundance of Trochamina hadai in samples collected in 1972-73 by Scott (1974) in Padilla and Samish Bays. 


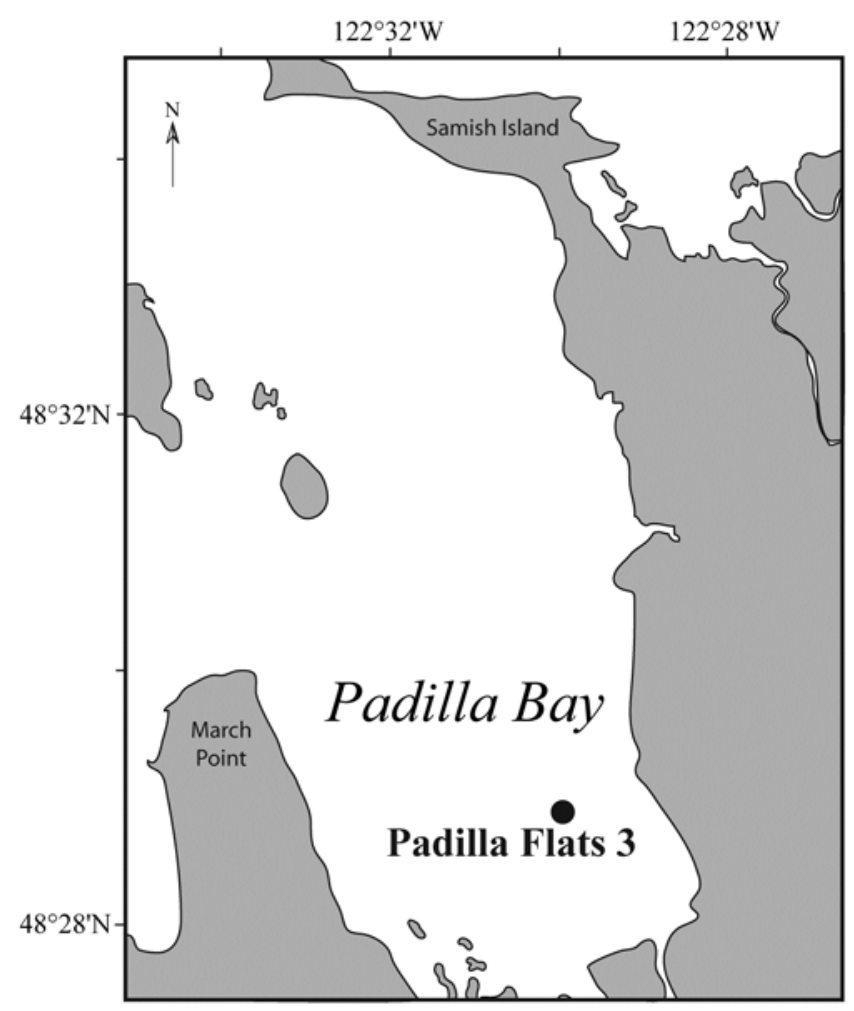

Figure 3. Location of Padilla Flats 3 core site in Padilla Bay.

\section{PADILLA FLATS 3}

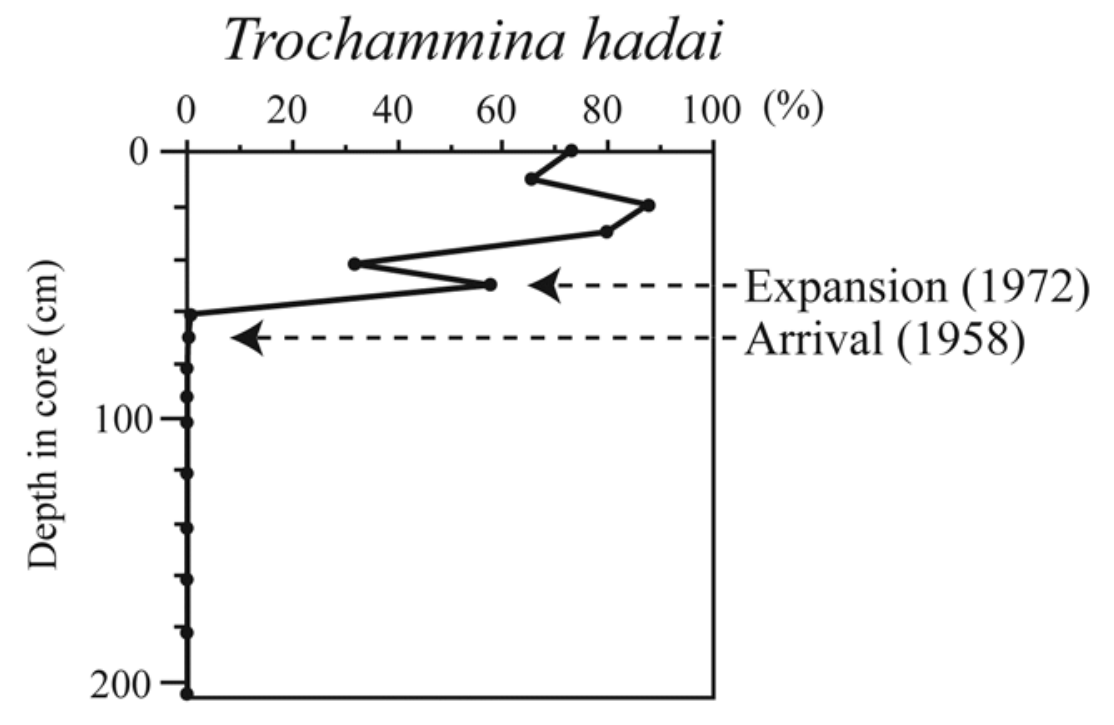

Figure 4. Percentage abundance of Trochammina hadai downcore in core Padilla Flats 3. Core sediments dated by PB-210 suggest that the invasive species arrived in 1958 and expanded in 1972. 


\title{
A Multi-Index Biomarker Approach to Understanding the Paleo-Occurrence of Eelgrass (Zostera marina) in the Nearshore of Puget Sound, Washington
}

\author{
By Robert J. Rosenbauer1', Eric Grossman², and Renee Takesue²
}

\begin{abstract}
The recent widespread loss and fragmentation of eelgrass (Zostera marina) meadows in Puget Sound have important ecological implications, including the loss of essential habitat for juvenile salmon. Eelgrass die offs have been well documented and often attributed to a decline in water quality (Moore and others, 1996; Kamermans, 1999, 2002; Hitoshi and others, 2002). However, it is unknown whether these die offs are a recent phenomenon, exacerbated by anthropogenic activities, or are part of a natural bio-geological cycle. Our objectives were to develop an analytical scheme and diagnostic chemical signature for eelgrass and to measure its spatial and temporal occurrence in sediment cores. We collected surface grab samples and long sediment cores in Padilla Bay, where eelgrass now thrives, and in Westcott Bay where eelgrass has recently died off (figs. 1a and 1b). We used concentrations of the low-molecular weight $n$ alkanes $\left(n \mathrm{C}_{17}\right.$ and $\left.n \mathrm{C}_{19}\right)$ and the plant sterols (stigmasterol, sitosterol, and campesterol) to estimate the amount of eelgrass in the sediment cores. High-molecular weight $n$-alkanes $\left(n \mathrm{C}_{27}\right.$ and $n \mathrm{C}_{29}$ ) present in some sediment samples indicate that some of the higher-plant sterols could be derived from terrigenous sources. The presence of algae also interfered with the eelgrass signal and can be identified by a variety of compounds. Measurements of compound specific isotope ratios and lignin phenols may help resolve these interferences.
\end{abstract}

Key Words: eelgrass, biomarkers, hydrocarbons

\section{Approach}

Our approach was to develop a multi-index technique using lipid biomarkers found in eelgrass to identify its presence in sediment. Specific hydrocarbons, in particular $n \mathrm{C}_{17}$ and $n \mathrm{C}_{19}$ $n$-alkanes with an odd-over-even (OE) carbon number preference (figs. 2a and 2b), in combination with the higher-plant sterols stigmasterol, $\beta$-sitosterol, and campesterol (fig. 3), are compounds isolated from seagrass (Botello and Mandelli, 1978; Matsumoto and others, 2001).

The $n \mathrm{C}_{19} n$-alkane was most commonly the predominant hydrocarbon extracted from leaves of eelgrass samples from Westcott Bay (fig. 2). For a smaller number of eelgrass samples, the $n \mathrm{C}_{17} n$-alkane was the predominant hydrocarbon extracted, indicating a possible sub-species of eelgrass (fig. 3).

1U.S. Geological Survey, Coastal and Marine Geology, 345 Middlefield Road, Menlo Park, CA 94025; brosenbauer@usgs.gov 2U.S. Geological Survey, Western Coastal and Marine Geology Program, Pacific Science Center, 400 Natural Bridges Dr., Santa Cruz, CA 95060 


\section{Results}

Analyses of sediment cores from Wescott and Padilla Bays in Puget Sound and in several pocket estuaries show considerable variation in these compound concentrations downcore, suggesting that eelgrass biomass has varied over the past 150 years (fig. 4).

Assuming that all of the $n \mathrm{C}_{17}$ and $n \mathrm{C}_{19} n$-alkanes extracted from the sediment were extracted from eelgrass, and having measured the concentration of these compounds in pure eelgrass, we estimated the amount of eelgrass in each sample interval downcore on a dry weight basis for the Paddila v1 and Westcott cores (figs. 5a and 5b, respectively). This interpretation may be confounded by a $n \mathrm{C}_{19} n$-alkane, possibly derived from algae (Botello and Mandelli 1978), as well as terrigenous plant sterols suggested by the presence of $n \mathrm{C}_{27}$ and $n \mathrm{C}_{29} n$-alkanes (fig. 6) (Eglinton and Hamilton, 1963). Both the $n \mathrm{C}_{29} n$-alkane and the higher plant sterols indicate in influx of terrigenous material about 50 years ago.

Algae, often but not always, can be identified by a bell-shaped pattern of $n$-alkanes, the presence of algal derived $\mathrm{C}_{20}$ and $\mathrm{C}_{25}$ highly branched isoprenoids (HBI), and/or sterols such as cholesterol, desmosterol, and brassicasterol. Compound specific isotope ratios (CSIR) may help resolve these interferences, because $z$. marina is a $\mathrm{C} 3$ type plant with some $\mathrm{C} 4$ characteristics, such as ${ }^{13} \mathrm{C}$-enriched $n$-alkanes (fig. 2) (Canuel and others, 1997). Measurements of the $\delta^{13} \mathrm{C}$ for the $n \mathrm{C}_{15}, n \mathrm{C}_{17}$, and $n \mathrm{C}_{19} n$-alkanes from the leaves of Z. marina averaged $12 \%$, in contrast with typical ranges of $18-22 \%$ for algae derived $n$-alkanes and 20-27 percent for terrigenous plant $n$ alkanes. We also are investigating the use of lignin phenols as a possible biomarker for eelgrass abundance.

\section{Acknowledgments}

We would like to acknowledge Aaron Powers for his help in carrying out the laboratory analyses and Elena Nilsen who helped develop the analytical procedures.

\section{References Cited}

Asche, S., Michaud, A.L., and Brenna, J.T., 2003, Sourcing organic compounds based on natural isotopic variations measured by high precision isotope ratio mass spectrometry: Organic Chemistry, v. 7, 15, p. 1527-1543

Botello, A.V., and Mandelli, E.F., 1978, Distribution of n-paraffins in sea-grasses, benthic algae, oysters and recent sediments from Terminos Lagoon, Campeche, Mexico: Bulletin of Environmental Contamination and Toxicology, v. 19, no. 2, p. 162-170.

Canuel, E.A., Freeman, K.H., and Wakeham, S.G., 1997, Isotopic composition of lipid biomarker compounds in estuarine plants and surface sediments: Limnology and Oceanography, v. 42, p. 1570-1583.

Eglinton, G., and Hamilton, R.J., 1963, The distribution of alkanes, in Swain, T. (ed.), Chemical Plant Taxonomy: Academic Press, New York, p. 187-218.

Hitoshi, T., Makoto, T., Wataru, N., Toshinobu, T., and Mitsumasa, O., 2002, Deterioration of eelgrass, Zostera marina, meadows by water pollution in Seto Inland Sea, Japan: Marine Pollution Bulletin, v. 44, no. 11, p. 1253-1258. 
Kamermans, P., Hemminga, M.A., and de Jong, D.J., 1999, The significance of salinity and silicon levels for growth of a formerly estuarine eelgrass (Zostera marina) population (Lake Grevelingen, The Netherlands): Marine Biology, v. 133, p. 527-539.

Kamermans, P., Hemminga, M.A., Jurgen, F., Tack, M.A., Mateo, N.M., Matern, M., Stapel J., Verheyden, A., and Van Daele, T., 2002, Groundwater effects on diversity and abundance of lagoonal seagrasses in Kenya and on Zanzibar Island (East Africa): Marine Ecology Progress Series, v. 231, p. 75-83.

Matsumoto, K., Yamada, K., and Ishiwatari, R., 2001, Sources of 24-ethylcholest-5-en-3beta-ol in Japan Sea sediments over the past 30,000 years inferred from its carbon isotopic composition: Organic Geochemistry, v. 32, no.2, p. 259-269.

Moore, K.A., Neckles, H.A., and Orth, R.J., 1996, Zostera marina (eelgrass) growth and survival along a gradient of nutrients and turbidity in the lower Chesapeake Bay: Marine Ecology Progress Series, v. 142, p. 247-259. 

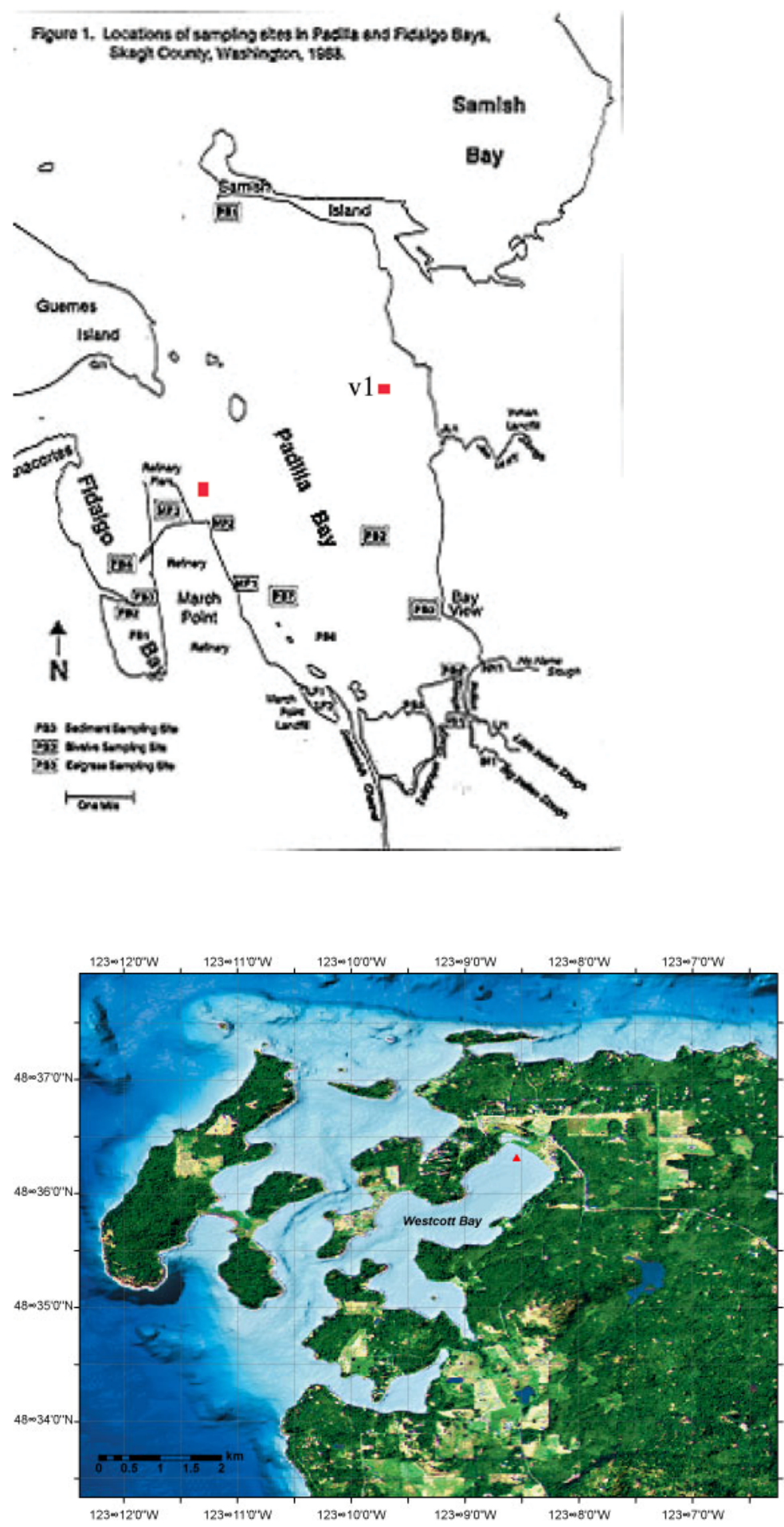

Figure 1. (A) Sampling sites in Padilla Bay, core v1 and the refinery core offshore March's Point; (B) Sampling site in Westcott Bay. 
A)
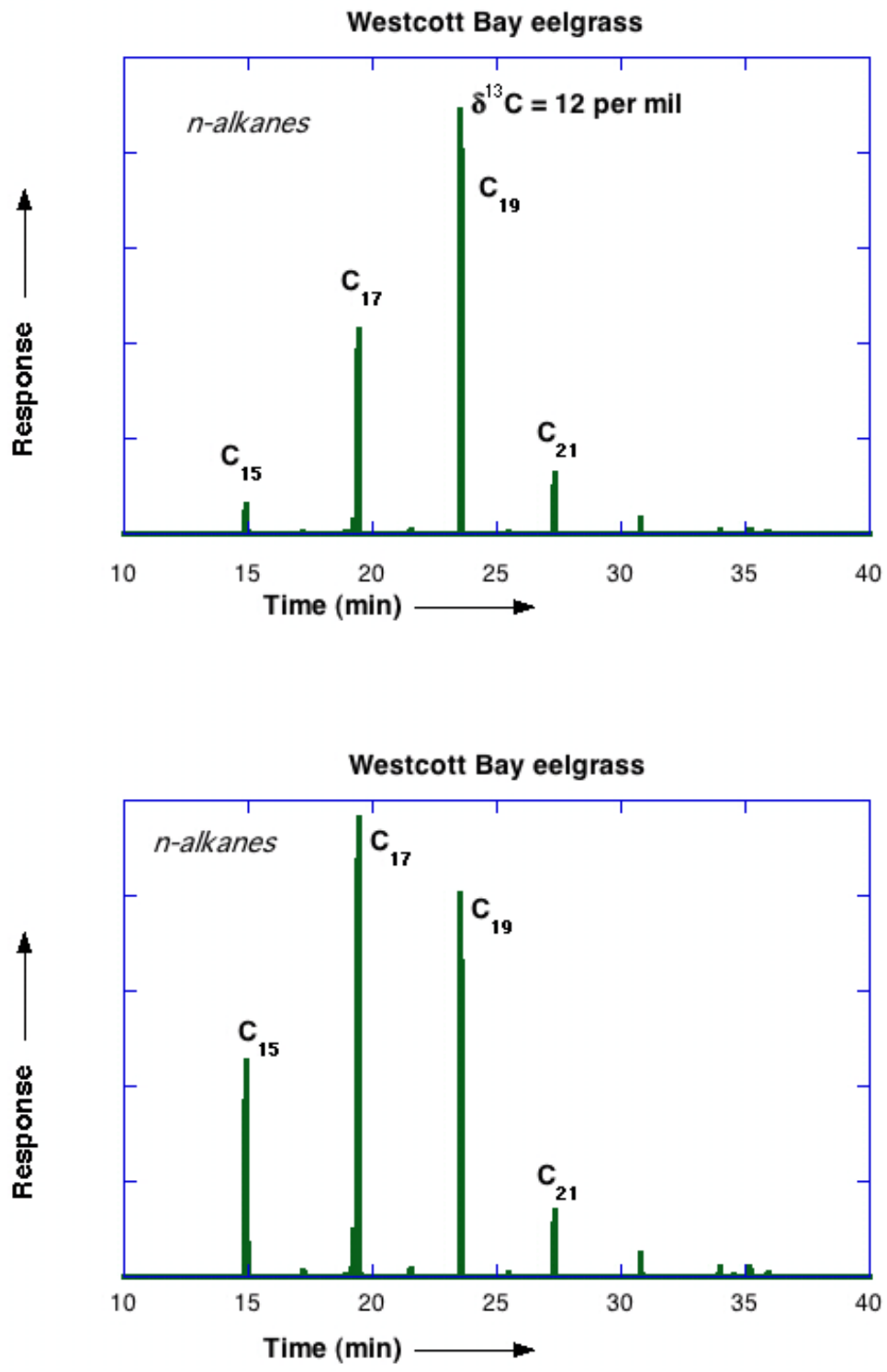

Figure 2. (A) Total ion chromatogram of $n$-alkanes extracted from eelgrass; (B) Total ion chromatogram of $\mathrm{n}$-alkanes extracted from eelgrass. Note that $\mathrm{nC} 17$ is greater than $\mathrm{nC} 19$. 


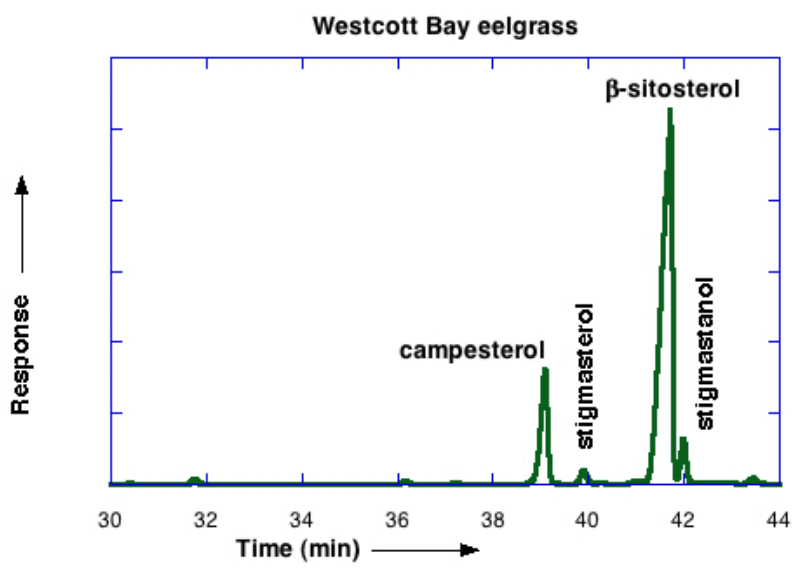

Figure 3. Total ion chromatogram of sterols found in extracts of eelgrass. 
A)
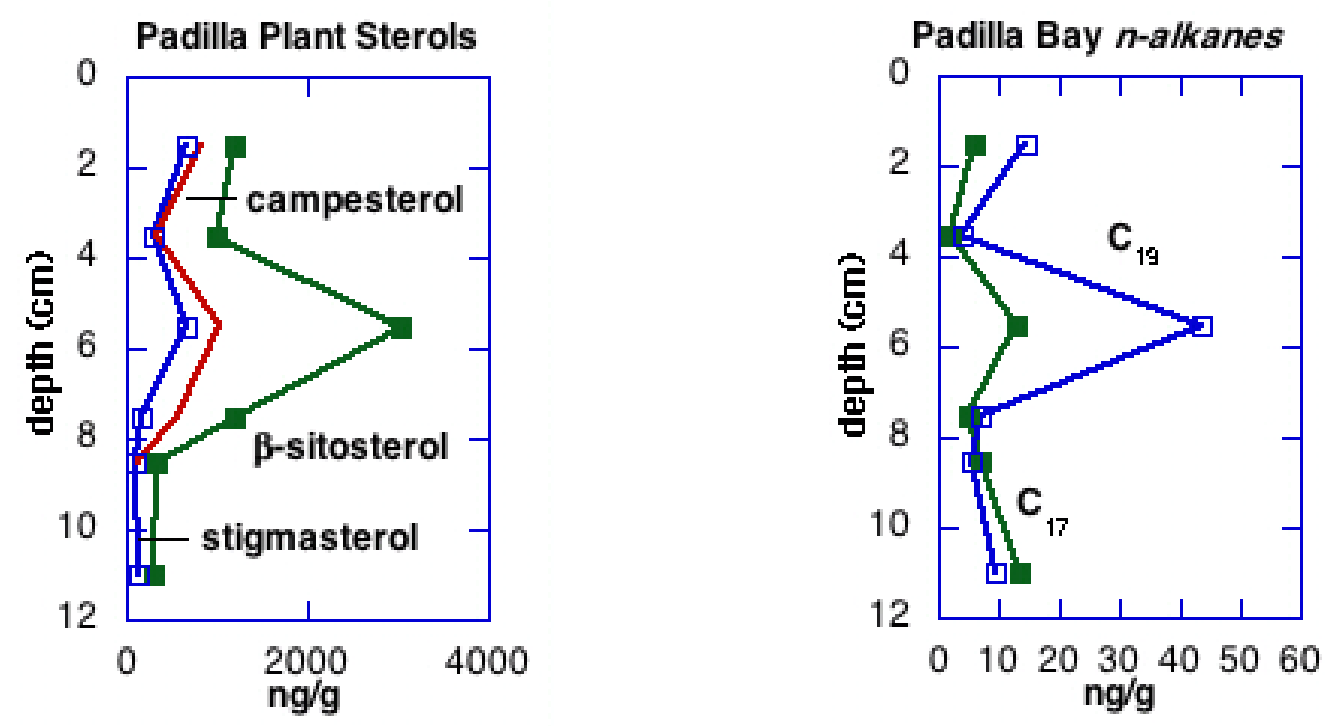

B)
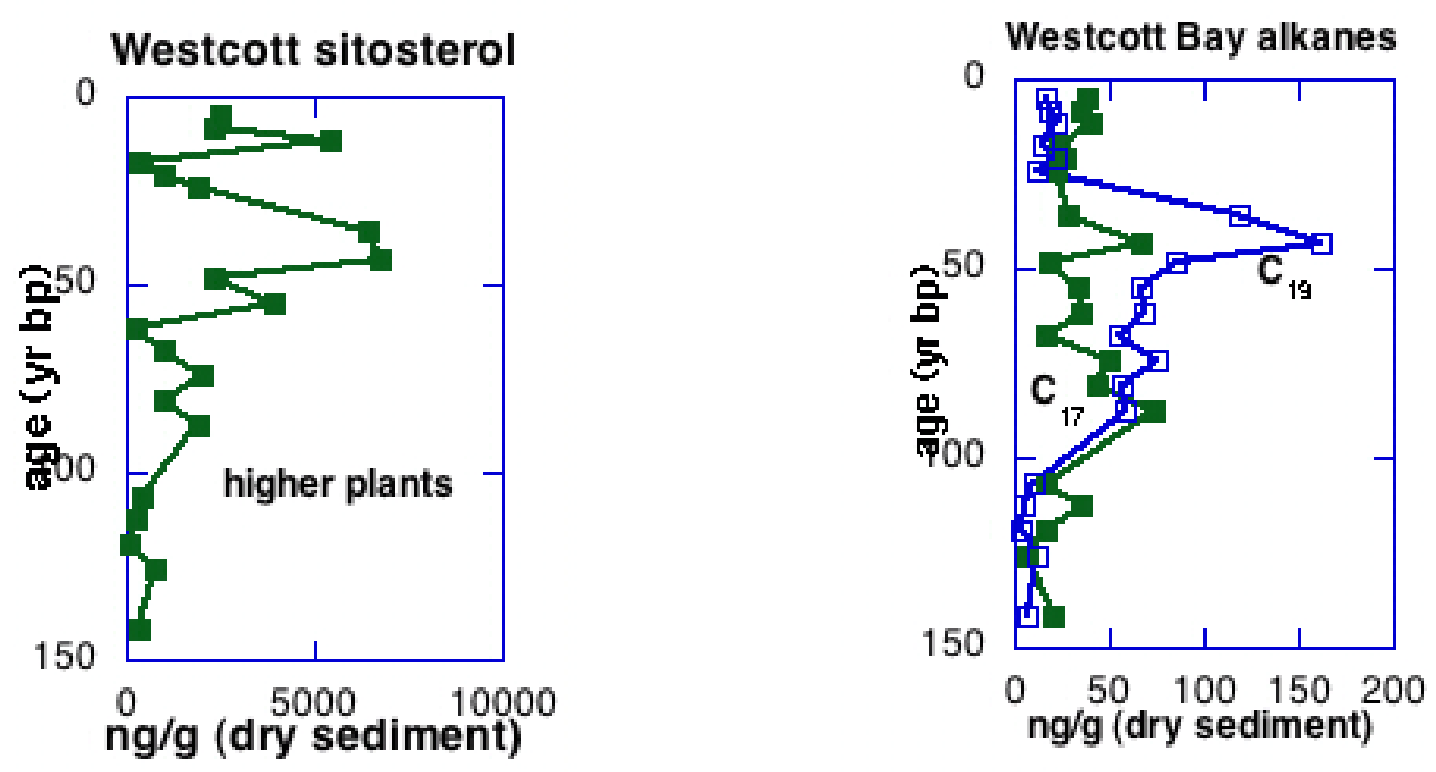

Figure 4. (A) Concentration of sterols and the $n \mathrm{C}_{17}$ and $n \mathrm{C}_{19}$ extracted from sediment core $\mathrm{v} 1$ in Padilla Bay; (B) Concentration of the plant sterol sitosterol and the $n \mathrm{C}_{17}$ and $n \mathrm{C}_{19}$ extracted from sediment core v1 in Wescott Bay. 

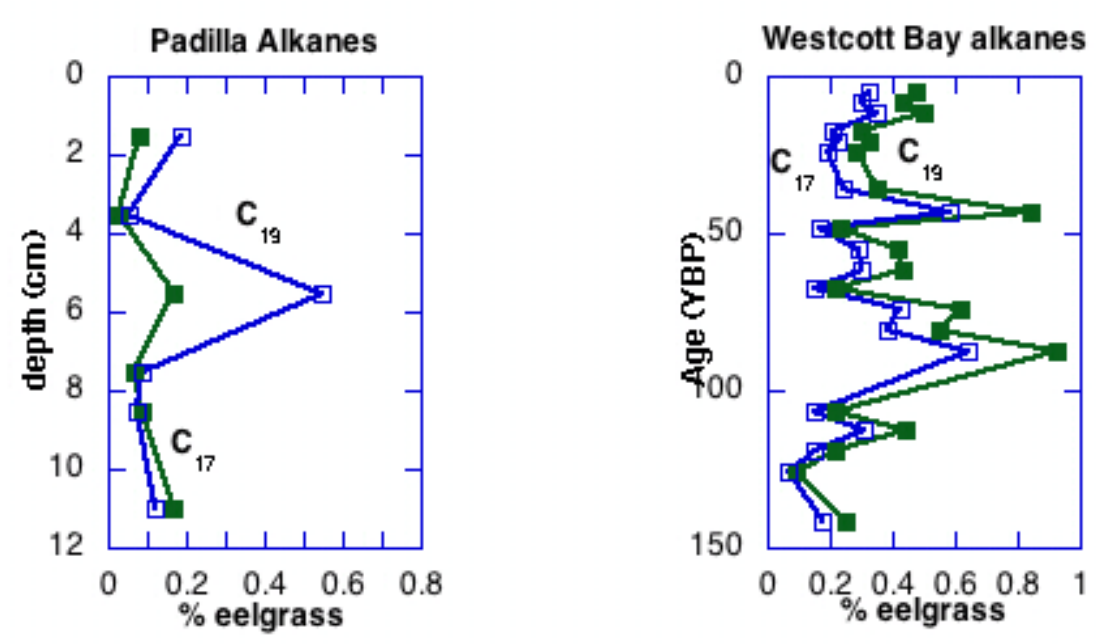

Figure 5. Estimated amount of eelgrass in sediment cores from Padilla Bay (v1) and Westcott Bay based on the amount of $n \mathrm{C}_{19}$ and $n \mathrm{C}_{17} n$-alkanes relative to pure eelgrass.

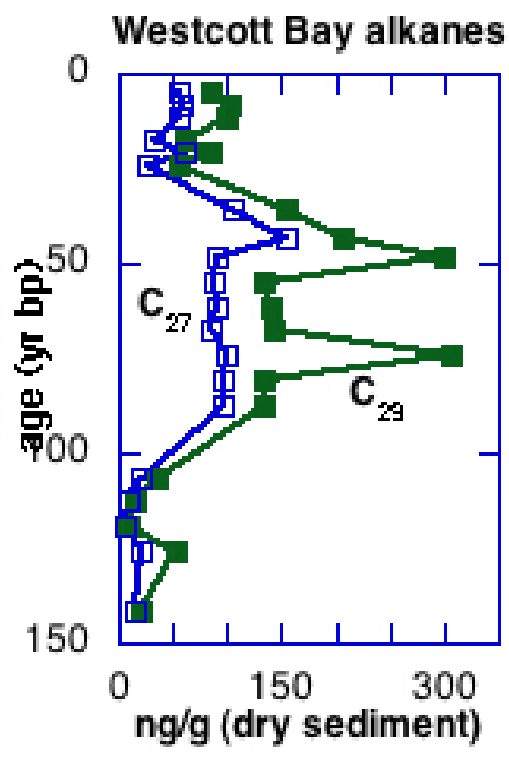

Figure 6. Concentration of sterols and the $n \mathrm{C}_{27}$ and $n \mathrm{C}_{29}$ extracted from sediment core 11 in Wescott Bay. 


\title{
Developing Models of Restoration Impacts to Nearshore Systems
}

By Eric Grossman ${ }^{1}$ and Bill Labiosa ${ }^{2}$

\begin{abstract}
Researchers with the US Geological Survey Coastal Habitats in Puget Sound (CHIPS) project on Restoration of Large River Deltas are studying modern nearshore habitats and land use impacts to develop predictive models and decision support tools to aid scientists, decisionmakers, and stakeholder in the restoration process. Project subtasks are focused on collecting quantitative information on modern nearshore habitat distribution, habitat use, recent environmental change, and the physical and socio-economic processes that influence habitat. We identified three types of models to integrate the collected information: (1) a GIS database-model that will store spatial attributes of habitat and land use traits and provide boundary conditions and inputs to numerical and decision-tree models (fig. 1); (2) a numerical hydrodynamic model that will simulate nearshore circulation and fluvial forcing to predict estuarine mixing, sediment transport, and habitat responses to a suite of inputs and stressors stemming from land-use changes (fig. 2); and (3) quantitative decision support tools (decision trees and influence diagrams) that can numerically evaluate economic and environmental costs and benefits of restoration alternatives (fig. 3). These model frameworks are expected to help forecast alternative outcomes, identify critical data gaps and uncertainties thereby helping to guide scientific inquiry, and engage stakeholders in the process of restoration and formulation of acceptable restoration strategies that balance ecologic and socioeconomic needs.
\end{abstract}

1U.S. Geological Survey, Western Coastal and Marine Geology Program, Pacific Science Center, 400 Natural Bridges Dr., Santa Cruz, CA 95060; egrossman@usgs.gov

2U.S. Geological Survey, Menlo Park, CA 


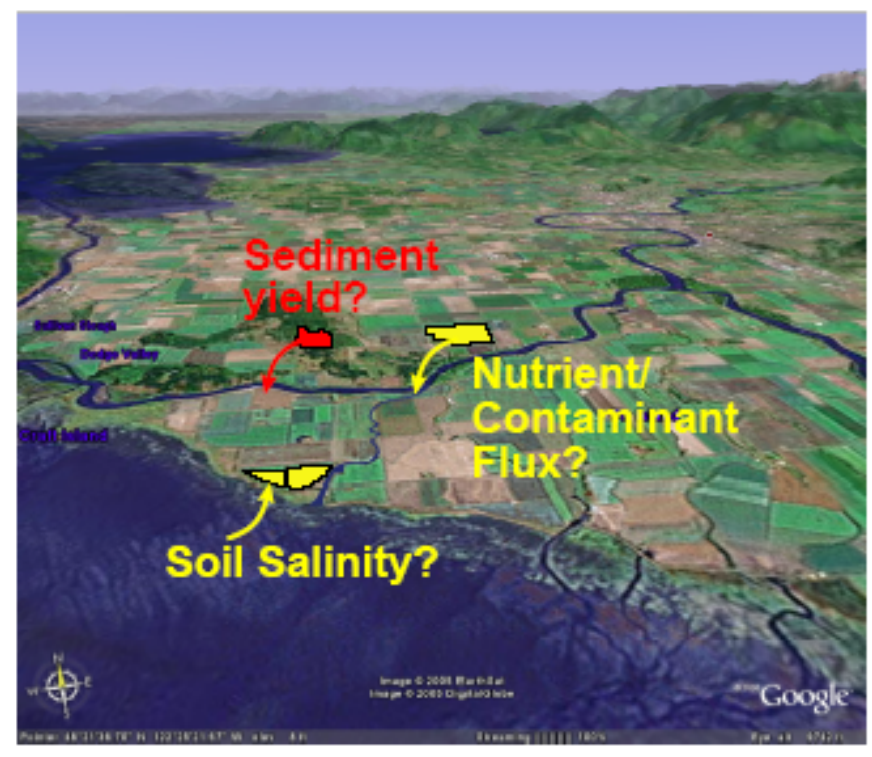

Figure 1. Diagram illustrating GIS approach to quantifying land use impacts/stressors to nearshore habitat (e.g. sediment inputs, nutrient flux) and modeling future hydrodynamic influences on environmental parameters (e.g. soil salinity) as inputs to process models.

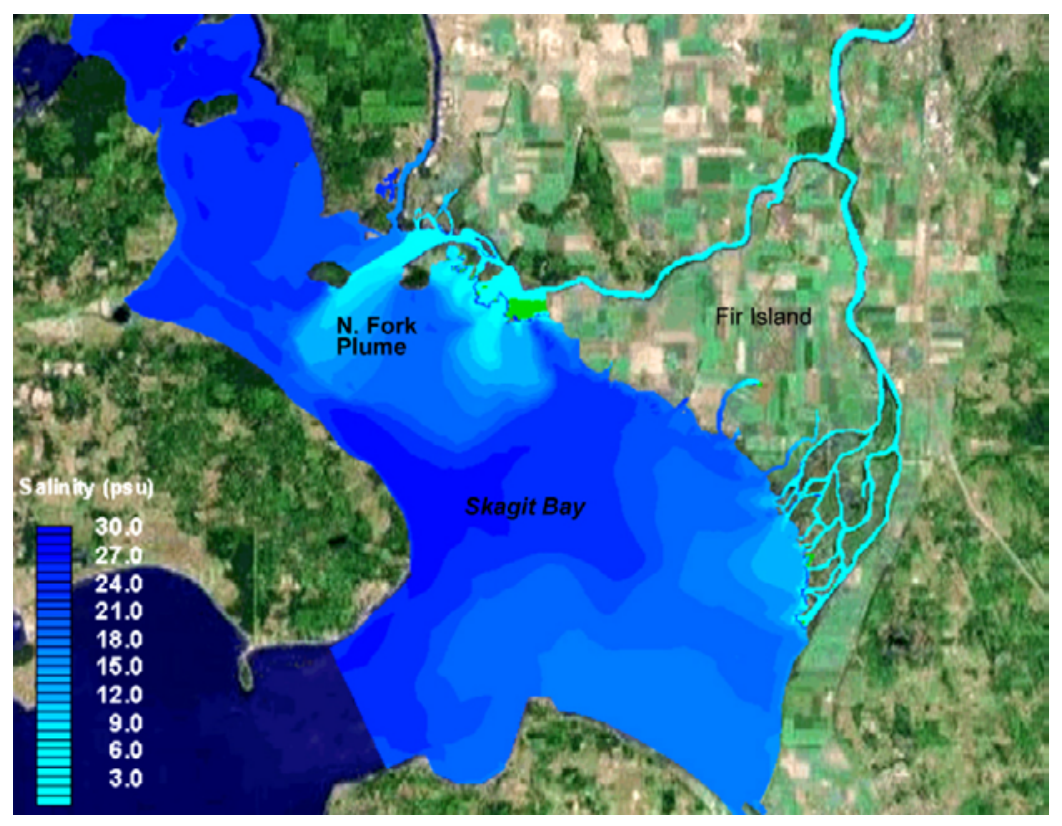

Figure 2. Example of a hydrodynamic process model that can simulate nearshore circulation (example here of Skagit Bay surface salinity) and variability in nearshore habitat conditions stemming from natural processes and land use (courtesy of Battelle). 


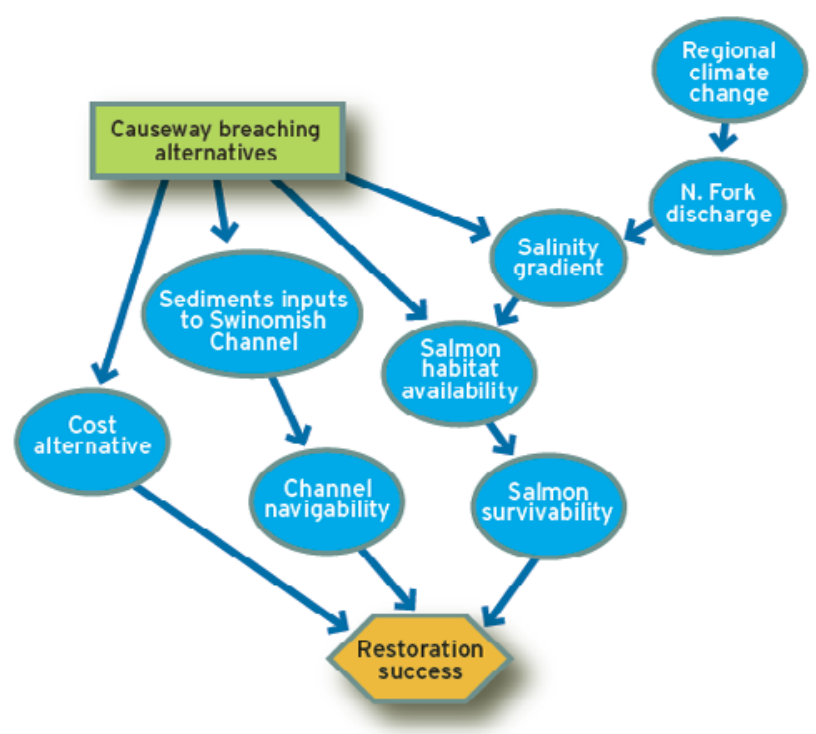

Figure 3. Example of an influence diagram for the McGlinn Island causeway breaching decision. The uncertainties include future regional climate change and its effects on discharge in the North Fork of the Skagit River; the effects of the causeway breaching alternatives on the salinity gradient, salmon habitat availability, and sediment inputs to Swinomish Channel; the effects of sediment inputs on channel navigation; and the effects of habitat availability on salmon survival. Several of these uncertain variables are also performance measures, as indicated by arrows into the multi-attribute utility node, "Restoration success." 


\title{
Consequences of the Elwha River Dam Removal on Nearshore Habitats and Ecosystems-Project Overview
}

By Jeffrey Duda ${ }^{1}$

\begin{abstract}
A wide variety of human activities simultaneously affect coastal habitats throughout Puget Sound. Identifying the most significant effects and developing restoration strategies to address them requires a thorough understanding of how terrestrial and freshwater ecosystems are linked to marine ecosystems through the nearshore, which spans freshwater, estuary, and intertidal habitats. The few places in Puget Sound with relatively little human disturbance are critical for understanding the ecological functions of the nearshore, especially in terms of the connectivity of freshwater and marine systems. River basins with relatively intact ecological functions connected to the nearshore are essential to the recovery of threatened biota, such as Puget Sound Chinook salmon, by supporting populations with a low risk of extinction. Indeed, the success of smaller scale restoration efforts throughout the Puget Sound region may depend on the continued viability of low risk populations inhabiting basins and nearshore areas with relatively little human disturbance.

The U.S. Department of the Interior's Elwha River Restoration Project (ERRP) is a historic step towards re-establishing the physical and biological processes that provide connectivity between freshwater and marine ecosystems in the Puget Sound. According to scientific consensus at 4 workshops (Randle and others, 2003; CCMRC, 2004; Schreiner and Winter, 2005; Stolnack and others, 2005) on research needs related to the ERRP, these interconnected zones will undergo significant changes due to the removal of two dams and the associated river restoration. The USGS and other resource agencies have begun to define sediment transport, biological conditions of the river, and the physical structure of the intertidal zone. However, an interdisciplinary research program intended to describe the links between river and intertidal ecosystems, particularly as they relate to important biota (e.g., salmon and shellfish), and the key processes required for the sustainability of their habitats is still needed.

We propose to develop techniques for investigating and tracking changes in key physical and biological processes and their consequences for the geomorphic structure of habitats and trophic structure of the ecosystem through the dam removal process. The investigation reflects the temporal context of the restoration project by dividing activities into three periods: (a) Dammed - before the dams are removed, (b) Dam Removal - during and immediately following the removals when the system is responding to the erosion of reservoir deposits, and (c) Recovery - the recovery period as the near-shore reestablishes habitat and salmon return in significant numbers to the river (fig. 1).
\end{abstract}

Key Words: Elwha, Dam Removal, Ecosystem Restoration, Salmon

1 U. S. Geological Survey, Western Fisheries Research Center, 6505 NE 65th Street, Seattle, WA 98115. jeff_duda@usgs.gov 


\section{Preliminary Work}

During the first year of this effort (FY06), we conducted fieldwork in support of three sub-tasks to fill important information gaps. These projects were also strategic, in that they added value to existing projects by the USGS and our key partners working in the lower river, estuary, and nearshore.

The first subtask addressed the physical processes in the nearshore, to better understand the exchange rates between the river, estuary, and the Strait of Juan de Fuca. Measurements included a real-time kinematic global positioning system topographic survey (RTK-GPS), measurements of an erosion event triggered by a January storm surge, photographic and grainsize surveys of beach transects, and bathymetric and topographic surveys of the Elwha River mouth using acoustic Doppler current profiling (ADCP) and conductivity-temperature-depth (CTD) surveys.

Our second subtask addressed the nutrient status of the lower river, estuary, and nearshore. We are collecting monthly water samples from 7 different habitat types for analysis of total and dissolved nutrients. We also deployed benthic metabolism chambers in June and September to estimate metabolic rates through oxygen consumption. These deployments, in concert with previous nutrient studies (Munn and others, 1998) defining the oligotrophic status of the Elwha River system, suggested very low rates of primary productivity.

Finally, our third sub-task addressed habitat utilization by juvenile Chinook salmon. In many Pacific Northwest river systems, use of estuaries and deltas is an important life history strategy that significantly contributes to adult survival. We collected 121 juvenile Chinook salmon from 5 different habitat types between March and October. Roughly one-half of the fish were collected prior to the release of 1.1 million hatchery fry in the middle of June. Laboratory analyses of otoliths extracted from the fish is ongoing, with a goal of identifying patterns that we can use to identify habitat specific residence time and growth rates.

\section{References Cited}

Clallam County Marine Resources Committee [CCMRC], 2004, Technical nearshore restoration in the central Strait of Juan de Fuca: Prepared by Triangle Associates, Seattle, WA. Available Online (http://www.clallammrc.org/CCMRC/Workshop\%20CSJ.pdf)

Munn, M.D., Black, R.W., Haggland, A.L., Hummling, M.A., and Huffman, R.L.. 1998. An assessment of stream habitat and nutrients in the Elwha River basin: implications for restoration: U.S. Geological Survey Water-Resources Investigations Report 98-4223.

Randle, T.J., Bountry, J., Jackson, B., and Smillie, G., 2003, Elwha River restoration draft sediment monitoring and management plan: Recommendations of the Elwha River Physical Processes Monitoring Workshop: Bureau of Reclamation, Aug. 13-17, 2001, Port Angeles, WA, 56 p.

Schreiner, E., and Winter, B., 2005, Restoration of the Elwha River Ecosystem, Results of a Biological Monitoring/Research Workshop: March 18-19, 2003, Unpublished USGS Report, available online (http://fresc.usgs.gov/products\%5Cpapers\%5C1525_Schreiner.pdf).

Stolnack, S.A., Naiman, R.J., and Harrington, S.J., 2005, Elwha Research Planning Workshop: Summary Report. Unpublished University of Washington Report, available online (http://www.pc.ctc.edu/coe/pdfs/Stolnacketal2005ElwhaResearchRetreatSummary.pdf) 


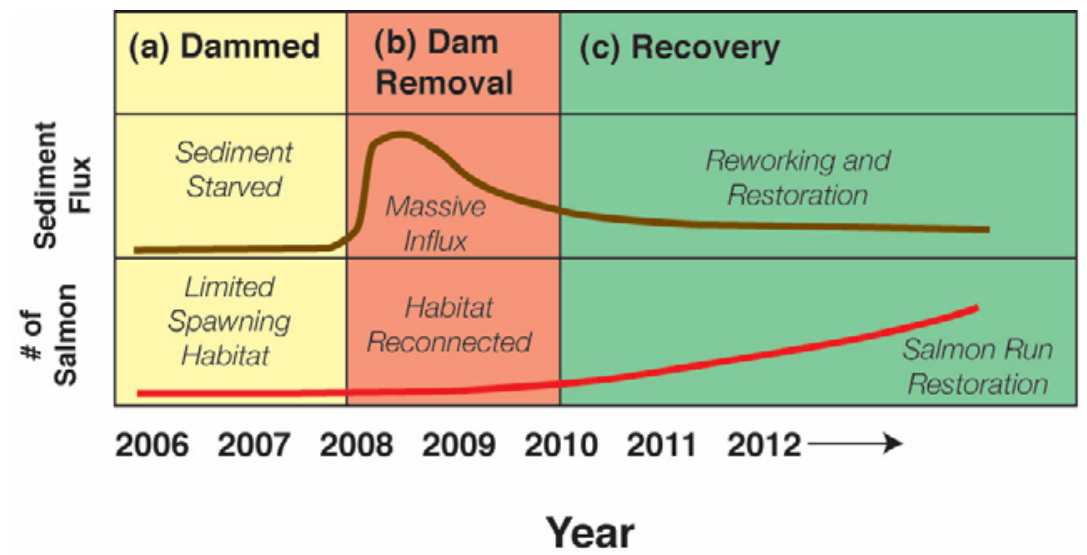

Figure 1. The temporal context of the Elwha River Restoration Project, including hypothetical responses for sediment and salmon. 


\title{
Beach and Nearshore Sedimentary Environments-Elwha River, Washington
}

\author{
By Jonathan Warrick ${ }^{1}$ and Guy Gelfenbaum ${ }^{2}$
}

\begin{abstract}
The removal of two dams on the Elwha River provides a unique opportunity to study the dispersal of very high rates of sediment discharge into a coastal region (fig. 1). The beach and nearshore sedimentary environments of the Elwha River delta are being investigated by USGS scientists with the goal of characterizing coastal geomorphic and sedimentary changes caused by dam removal. The hypothesis of this study is that the large rates of sediment discharge will alter beach and nearshore grain-size distributions and cause significant aggradation in some regions.
\end{abstract}

Key Words: Nearshore, bathymetry, sediment transport, beach geomorphology

\section{Beach Characterization}

We are using high resolution topographic and bathymetric mapping and newly developed techniques for measuring grain size. Surveys occur semi-annually, following the high-energy winter and the low-energy summer. We are using Real-Time Kinematic Global Positioning Systems (RTK GPS) along regular spaced transects for topographic and bathymetric mapping. To obtain beach topography, we hiked with GPS backpacks. We obtained bathymetry from small water craft with GPS and single-beam echo sounders. Example topographic data from the beach is shown in figure 2. Comparison of data from different surveys reveals that large changes have occurred in certain portions of the beach (fig. 3).

To characterize the grain-size of the beach, we are using a digital photographic analysis that we call a Cobble Cam. We use a tripod-mounted camera to take digital photographs of beach sediments along topographic survey lines. We then analyze images for grain-size using an autocorrelation technique (Rubin, 2004) that we calibrated specifically for Elwha beach sediment. Error analyses suggest that the 95 percent confidence interval for the technique is 0.5 phi. An example transect of the grain-size results are shown in figure 4.

The combination of the topographic and grain-size data are leading to a geomorphic description of the beach summarized in figure 5. During the coming year (FY07), we will be refining this schematic and including better measurements of grain-size and topographic variability and change with the goal of producing a peer-reviewed manuscript by the end of the fiscal year.

1U.S. Geological Survey, Pacific Science Center, 400 Natural Bridges Drive, Santa Cruz, CA, 95060; jon_warrick@usgs.gov

2U.S. Geological Survey, Menlo Park, CA 
Lastly, we are characterizing the nearshore sedimentary environment with a combination of sonar, video and grain-size mapping. A survey was conducted during spring 2005 by the USGS (fig. 6) and the results of this survey are currently being summarized to be published in an Open-File Report. The nearshore seabed is generally course-grained, and dominated by sand, gravel, cobble, boulders with some bedrock reefs.

\section{References Cited}

Rubin, D.M., 2004, A simple autocorrelation algorithm for determining grain size from digital images of sediment, Sedimentology, v. 74, no. 1, p. 160-165. 


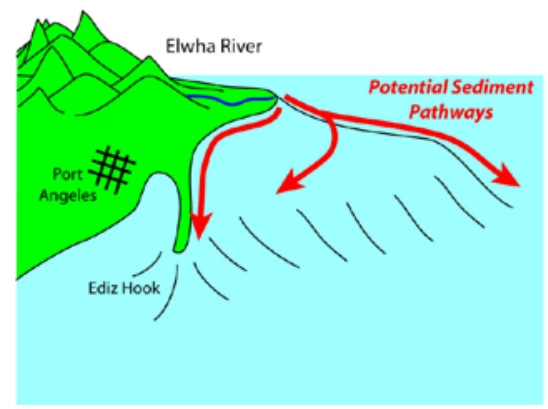

Figure 1. Potential pathways of sediment discharged from the Elwha River into the coastal ocean.

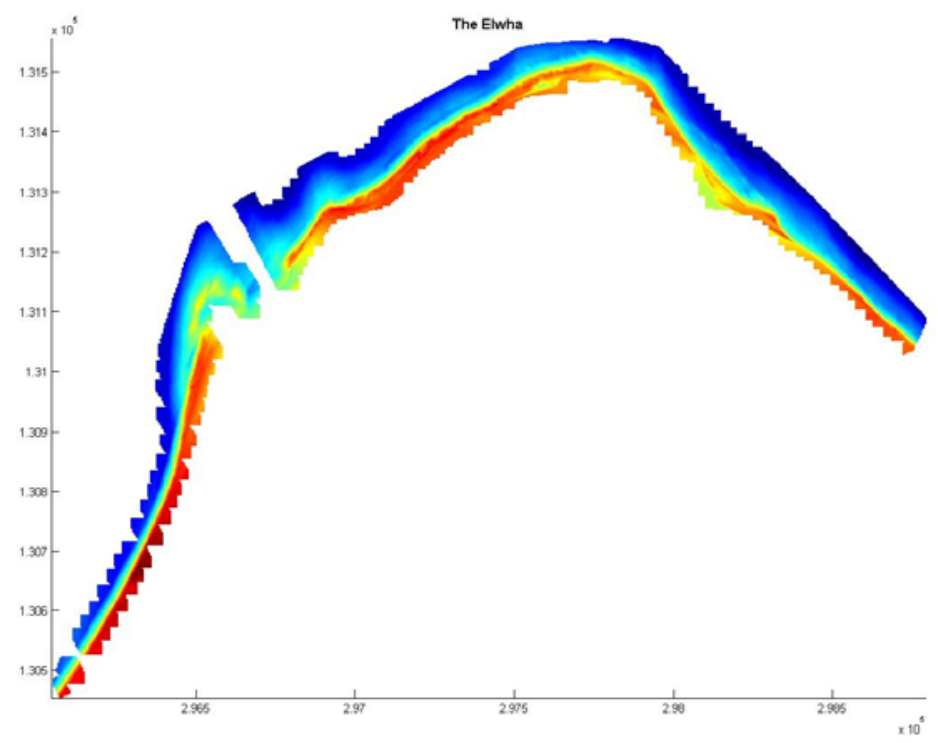

Figure 2. Topographic survey of the Elwha River delta using RTK GPS from April 2006. Blues are deeper depths, reds are shallower. 

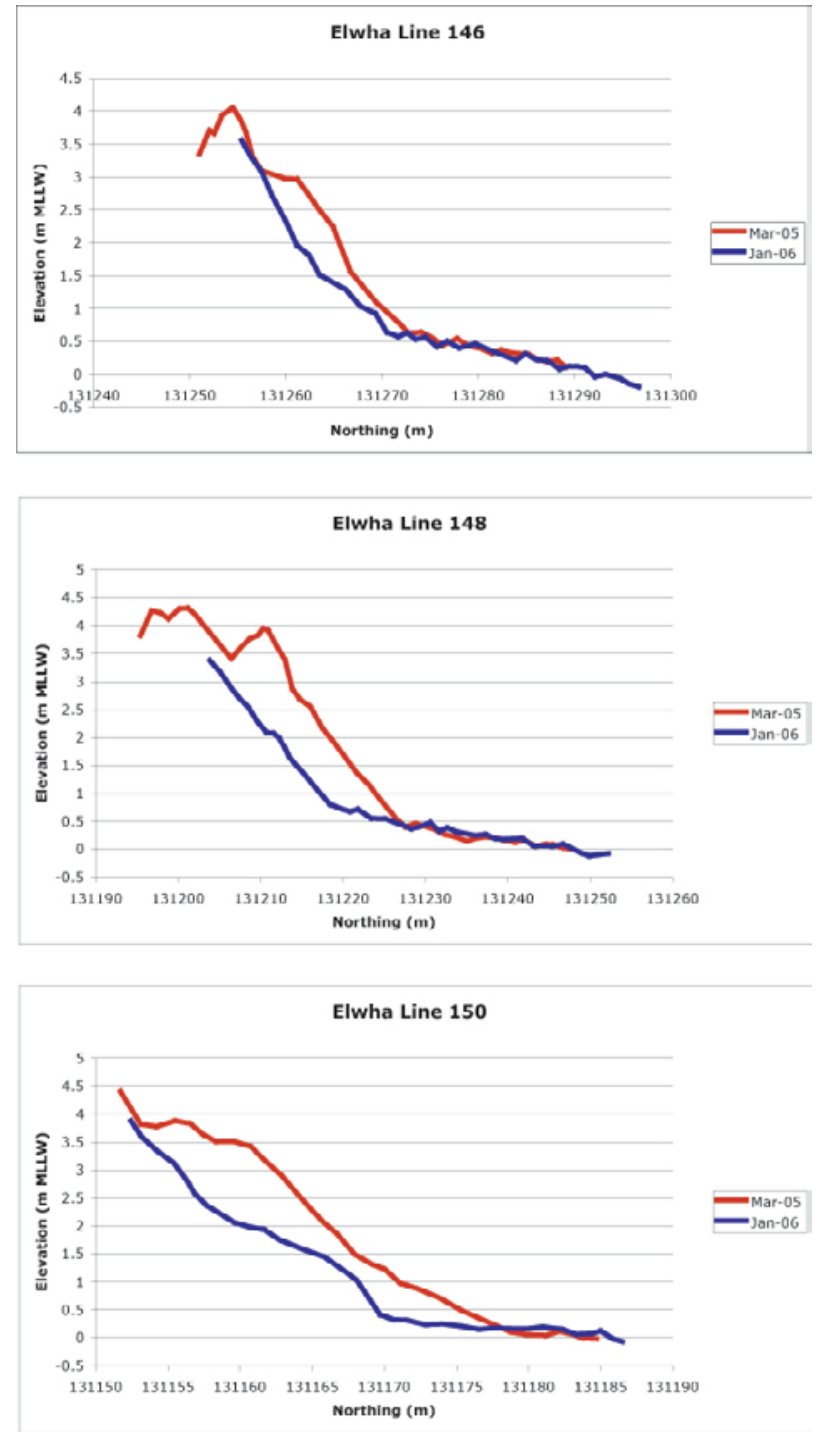

Figure 3. Example topographic cross-sections across the beach of the Elwha River delta obtained during March 2005 (red) and January 2006 (blue). 


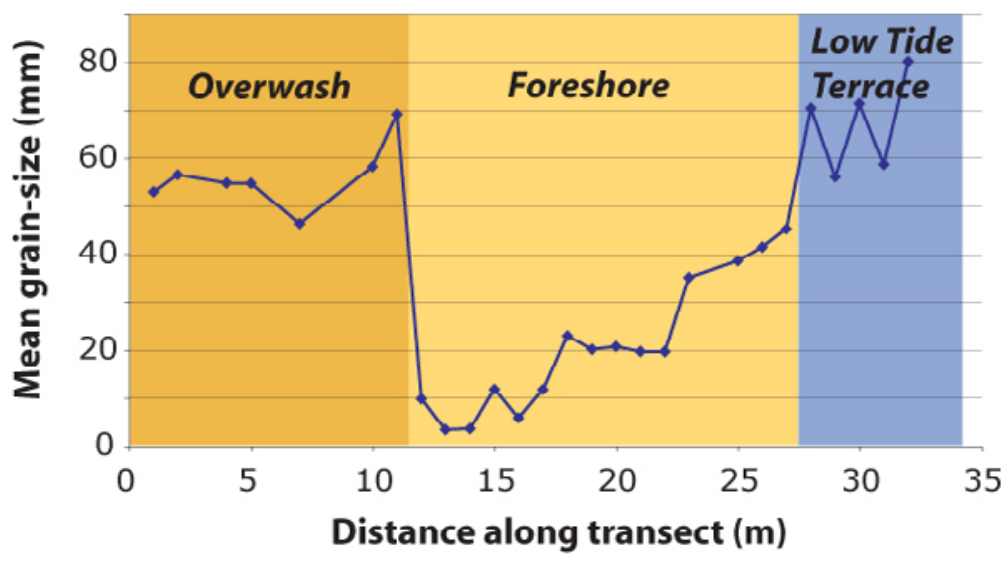

Figure 4. Example grain-size results from the Cobble Cam across a beach profile (see fig. 5 for beach terminology).

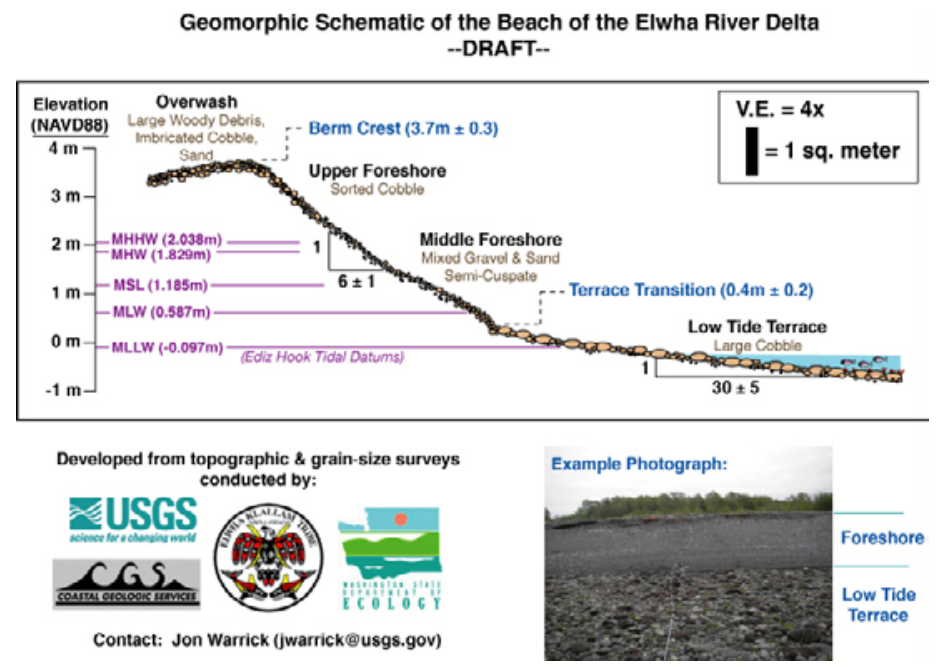

Figure 5. Typical geomorphic cross-section of the Elwha River Delta beach. 


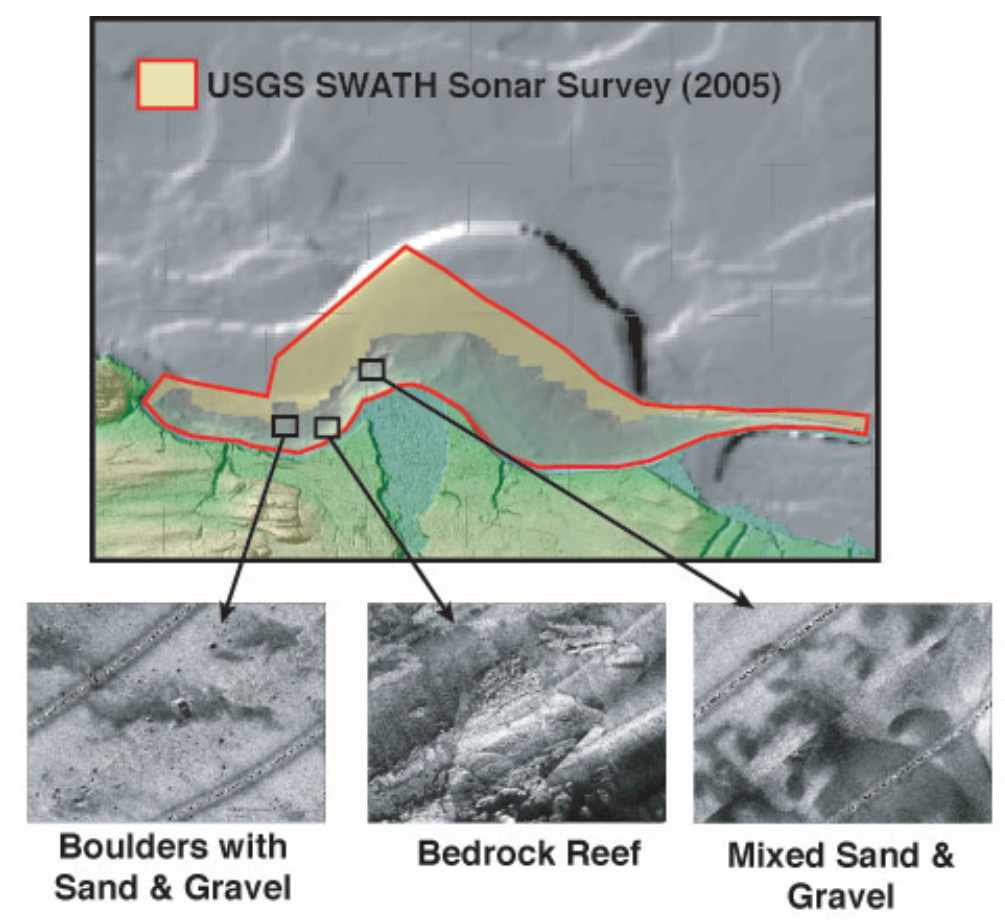

Figure 6. Geographic extent and example backscatter results of the Swath sonar survey of the Elwha nearshore. 


\title{
Linking Puget Sound Rivers to the Nearshore: Physical Processes and Nutrient Dynamics in the Lower Elwha River
}

\author{
By Christopher Konrad 1
}

\begin{abstract}
Removal of two dams on the Elwha River in the Olympic Peninsula, Washington, is expected to restore physical processes of the aquatic habitats in the nearshore, as well as biological processes that regulate nutrient dynamics from the river's headwaters to its estuary. In 2006, scientists from U.S. Geological Survey conducted preliminary investigations of the river's bathymetry, currents at its mouth, and primary production in the main stem and side channels to provide baseline information about physical and biological processes linking the river to the near shore. Preliminary results showed considerable channel migration in the lower river over a 16year period, a freshwater dominated plume at the mouth of the river during high flows, and low levels of benthic metabolism in the late spring and summer.
\end{abstract}

Key Words: Nearshore processes, river bathymetry, benthic metabolism, nutrients

\section{Preliminary Investigations}

We conducted a hydrographic survey in May 2006 to map the bathymetry and currents in lower $500 \mathrm{~m}$ of the river. We used a downward looking acoustic Doppler current profiler (ADCP), a depth sounder, a real-time kinetic global positioning system (RTK GPS) mounted on a small motor boat (fig. 1), and a water level recorder fixed at the downstream end of the reach. By integrating the output from these instruments, we were able to map with high precision $(<0.1$ $\mathrm{m}$ in vertical and horizontal position) the elevation of the riverbed and the speed and direction of currents. The resulting map of point elevations on the riverbed and adjacent point bar shows considerable change in channel position over the last 16 years (fig. 2).

To determine if a saltwater wedge extends above the beach at the river's mouth, we measured specific conductance at the downstream end of the survey. We detected no saltwater, which indicates that, during high flows, a freshwater plume likely extends off shore.

1U.S. Geological Survey, Washington Water Science Center, 934 Broadway, Suite 300, Tacoma, WA 98402, cpkonrad@usgs.gov 
With assistance from the USGS National Water Quality Assessment Nutrient Enrichment Effects Team, we investigated river metabolism (production and respiration) in June and August 2006. We estimated stream metabolism at two spatial scales: whole stream and individual cobbles. We continuously monitored dissolved oxygen at the upstream and downstream ends of reach (whole stream metabolism), and we measured dissolved oxygen in closed chambers where river water was re-circulated over rocks taken from the riverbed (individual cobble metabolism, fig. 3). Preliminary results using both techniques suggest that levels of metabolism are very low. Further investigation may use other techniques that can resolve lower rates of primary production.

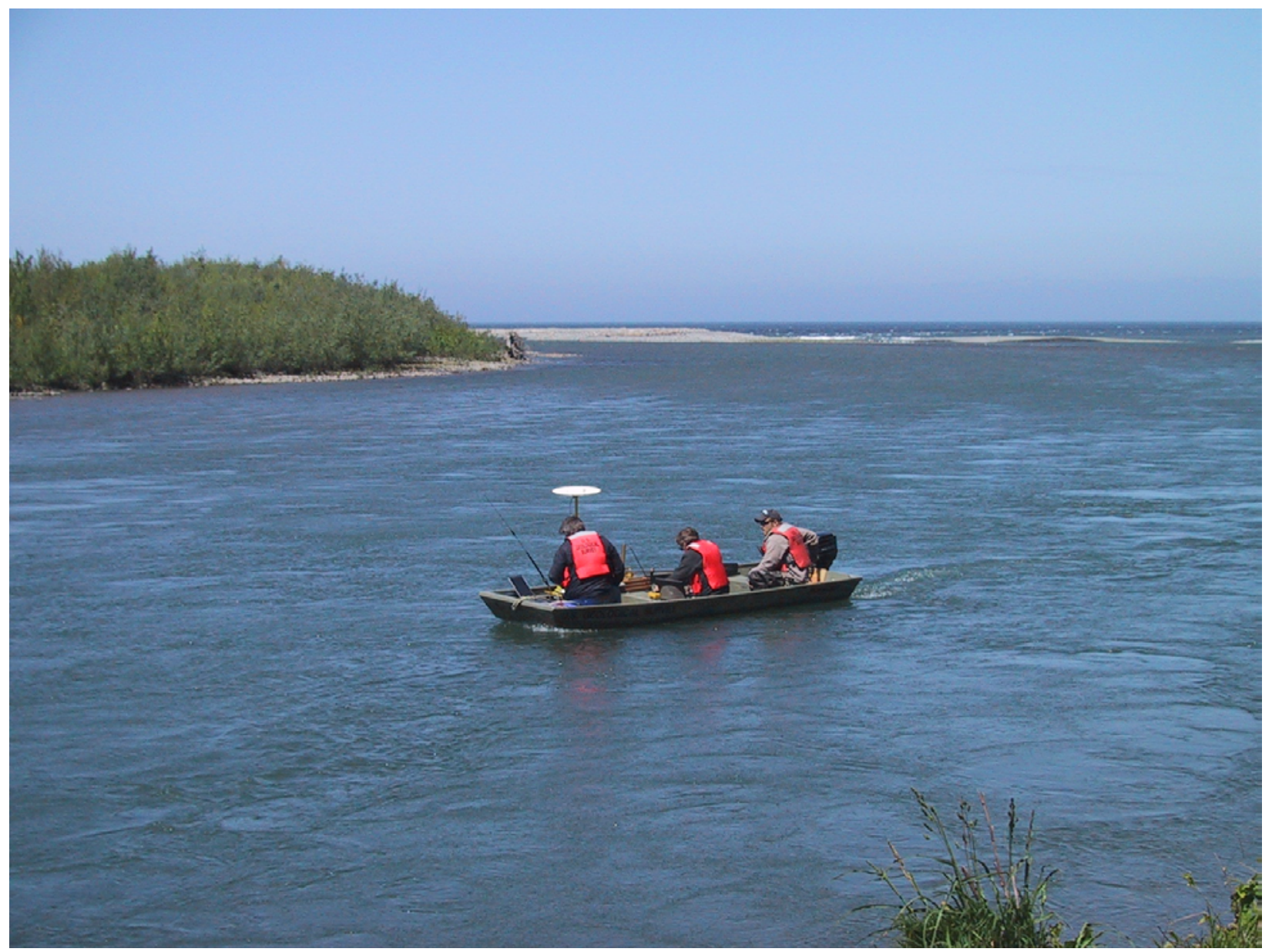

Figure 1. Hydrographic survey of the lower Elwha River in May 2006. 


\section{Legend gps_topo_pnts ELEVATION \\ $0.784-1.234$ \\ $1.235-1.671$ \\ $1.672-2.223$ \\ $2.224-2.726$ \\ - $2.727-3.374$}

\section{bathymetry \\ BED_ELEV \\ - $\quad-1.13--0.37$ \\ - $-0.36-0.06$ \\ - $\quad 0.07-0.39$ \\ - $\quad 0.40-0.75$ \\ $=0.76-1.32$}

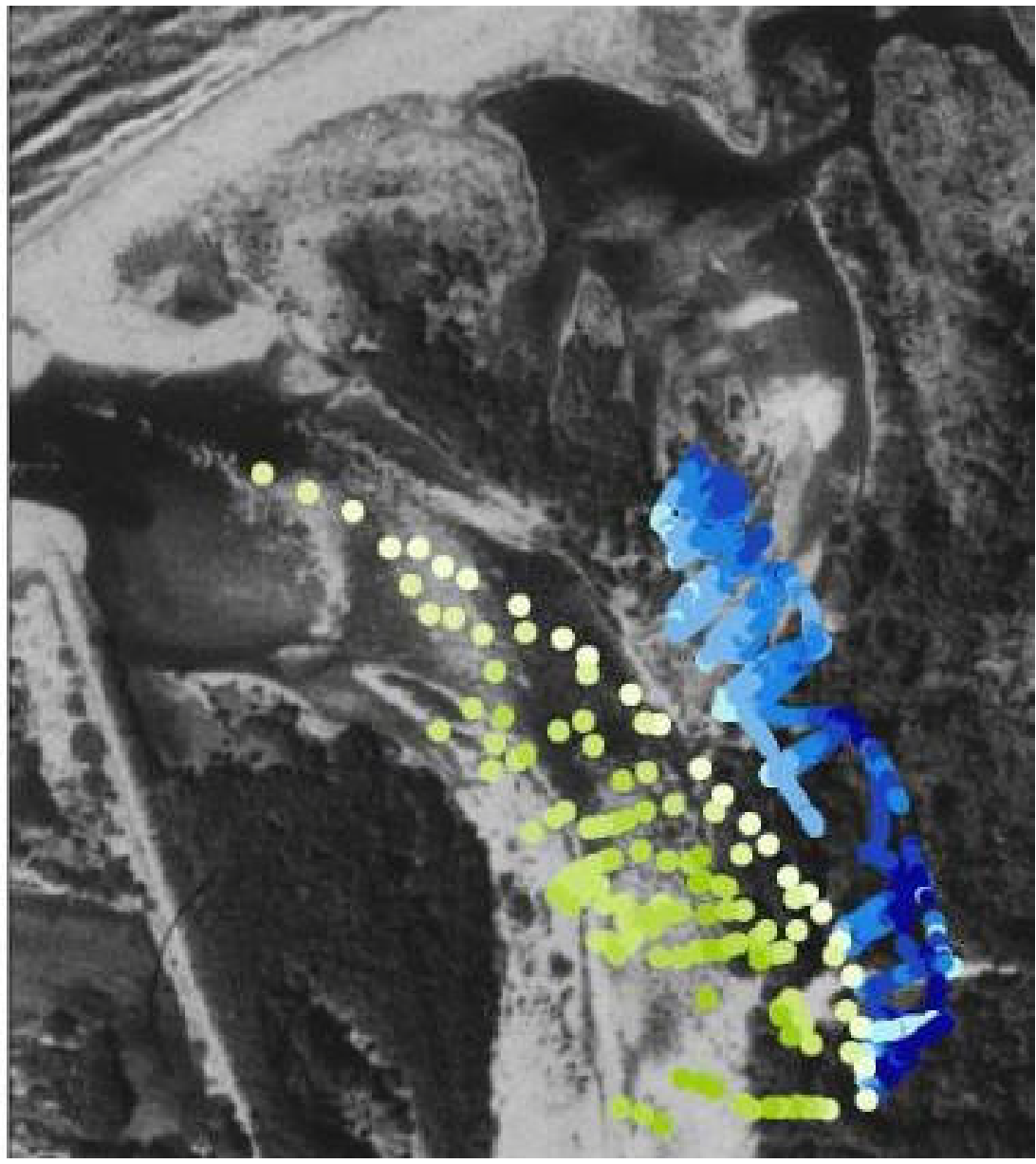

Figure 2. Point elevations of the lower Elwha River bed (blue) and adjacent point bar (green) with 1990 aerial photograph as background.

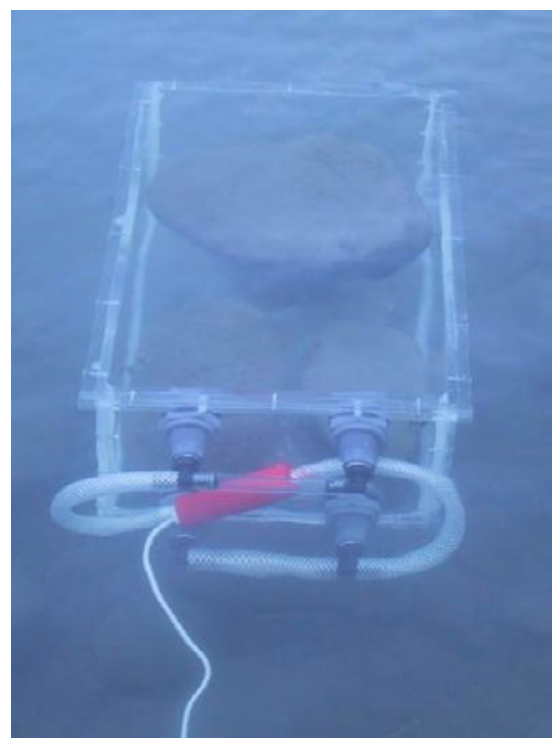

Figure 3. Chamber for measuring metabolism for individual cobbles. 


\title{
Evaluating Fish Responses to Removal of the Elwha River Dams in Shallow Water Coastal Habitats Adjacent to the Elwha River Mouth
}

By Kurt L. Fresh ${ }^{1}$, Josh Chamberlin², Larry Ward ${ }^{3}$, and Anna N. Kagley²

\begin{abstract}
Removal of two main stem dams on the Elwha River is scheduled to begin in 2012. Dam removal is expected to help restore natural sediment processes in the river, estuary, and coastal area of Puget Sound near the river's mouth. However, the short- and long-term effects of sediments formerly retained by the dams on fish and their habitats in this area are unknown. Federally protected salmon species use shallow water habitats in the area. A number of economically and ecologically important species spawn, rear, and migrate within shallow water habitats of Puget Sound. Since 2005, we have been collecting baseline data on the distribution and abundance of nearshore fish communities at sites in the eastern and central Strait of Juan de Fuca, from Discovery Bay to Crescent Bay. We identified 36 fish species, including four species of Pacific salmon, steelhead trout and cutthroat trout. We found wide distribution of several of the salmon species, juvenile ling cod, and post larval, juvenile, and adult surf smelt. Pink salmon were the most abundant of the salmon species collected in 2006. We found evidence that multiple spawnings of surf smelt were occurring in the several sample sites; we also collected gravid adults in several areas. Preliminary data suggest that fish responses to dam removal will vary by species, by habitat, by habitat distribution, and by the quantity and timing of sediment inputs, as well as by how sediment distributes once it reaches Puget Sound.
\end{abstract}

Key Words: Elwha River, nearshore, fish response, salmon

\section{Data Collection}

Sites were sampled on a monthly basis, weather and tide permitting, using a $32 \mathrm{~m}$ long beach seine between April and September. We also conducted limited sampling with a surface trawl in areas adjacent to beach seine sites.

\footnotetext{
${ }^{1}$ NOAA Fisheries, Northwest Fisheries Science Center, 2725 Montlake Blvd E., Seattle, WA. kurt.fresh@noaa.gov

${ }^{2}$ NOAA Fisheries, Northwest Fisheries Science Center, Seattle, WA

${ }^{3}$ Lower Elwha Klallam Tribe, Port Angeles, WA
} 


\title{
Using Otolith Analysis to Establish Habitat Use Patterns of Migrating Juvenile Chinook Salmon in the Elwha River
}

\author{
By Kimberly Larsen ${ }^{1}$, Jeffrey Duda², Karl Stenberg², Matt Beirne ${ }^{3}$, Mike McHenry ${ }^{3}$, Kurt Fresh ${ }^{4}$, and \\ Reginald Reisenbichler ${ }^{2}$
}

\begin{abstract}
As juvenile Chinook salmon migrate from freshwater rearing areas, they undergo the physiological, behavioral, and life history changes necessary for transition to life in the ocean. Estuaries are increasingly recognized as an important part of this migration (reviewed in Simenstad and others, 1982). It is hypothesized that salmon utilize estuarine habitats because they: a) have a higher growth potential; b) require a transition period prior to saltwater residence,; and c) provide areas where predators can more easily be avoided (Quinn, 2005). All of these factors may play a role in greater survival during the marine life history phase. However, there is a great deal of inherent variability associated with estuaries, especially in regards to their size, their physical processes, and their complexity. Although the role of estuaries has been deemed important for some Puget Sound Chinook populations (e.g., the Skagit River; Eric Beemer, Skagit River Systems Cooperative, written commun.) the importance of the Elwha River estuary and nearshore to Chinook salmon populations is relatively unknown.

In 2012, two of the largest dams ever considered for decommissioning will be removed, starting a long-term process of ecosystem restoration of the Elwha River. The removals will open over 70 miles of spawning habitat to salmon, much of which occurs in Olympic National Park. Considered a once-in-a-generation scientific opportunity, there is considerable research and monitoring proposed to establish baseline conditions of the river prior to dam removal, salmon recolonization, and ecosystem restoration. As part of the USGS Coastal Habitats in Puget Sound Initiative, we are establishing baseline levels of habitat utilization by Chinook salmon in the Elwha River prior to dam removal. The Elwha Klallam Tribe's fisheries office is currently conducting a biological assessment of the Elwha River estuary, including regular seining of two freshwater lake habitats at the river's mouth. Also, scientists from the NOAA Northwest Fisheries Science Center have been conducting surface trawls and beach seining in the Elwha River nearshore. Working with these partners, we collected 121 juvenile Chinook salmon from 5 different habitat types between March and October 2006. Based upon work in other Puget Sound river systems, we divided our sampling into freshwater, forested riverine tidal (FRT), emergent forested transition (EFT), estuarine emergent marsh (EEM), and nearshore habitat types (fig. 1). Roughly one-half of the fish were collected prior to release of 1.1 million hatchery fry in the middle of June.
\end{abstract}

\footnotetext{
1U.S. Geological Survey, Western Fisheries Research Center, 6505 NE 65 $5^{\text {th }}$ Street, Seattle, WA 98115. kalarsen@usgs.gov

2U.S. Geological Survey, Seattle, WA

${ }^{3}$ Lower Elwha Klallam Tribe, Port Angeles, WA

${ }^{4}$ NOAA Fisheries, Seattle, WA
} 
Our goals were to utilize otolith microstructure to determine patterns of estuarine habitat use by migrating juvenile Chinook salmon in the Elwha River (fig. 1). Our previous work in other river systems, with more extensive and complex estuarine habitats, showed otoliths with distinct checks and patterns of growth. These different patterns corresponded with a transition in habitat type, allowing us to identify and quantify differential habitat use. We did not find this level of specificity in our analysis of Elwha River Chinook otoliths.

Key Words: Elwha, Chinook, otolith, habitat

\section{Results and Conclusions}

Elwha hatchery fish displayed a clear thermal mark (WA State Department of Fish and Wildlife otolith marking program) early in development allowing us to distinguish hatchery caught Chinook from wild caught (fig. 2).

Our preliminary results of wild caught Chinook found two distinct otolith microstructure patterns. The first pattern represented fish resident or captured within freshwater and FRT habitats (fig. 3). However, there was not a distinct check or increased growth apparent to or between freshwater and FRT habitats. The second pattern, characterized by increased daily growth, represented fish captured within EFT, EEM, and nearshore habitat types (fig. 4). Again, even though we analyzed otoliths collected from EFT, EEM, and nearshore, we were unable to discover unique patterns of growth allowing us to differentiate among these habitats. It is not known at this time whether these results are due to low sample size, limitations of the technique, or habitat features unique to the Elwha River system.

Once we could recognize the different patterns of growth associated with transition from freshwater to estuarine habitats, we used the mean increment width (MIW) as an indirect measure growth within each habitat. The region of the otolith corresponding to freshwater growth was quite similar in MIW, regardless of the habitat where fish were caught, with an average of 1.72 microns (fig. 5). The region of the otoliths assigned as delta growth showed an increase in MIW by approximately about 30 percent, with an average of 2.24 microns. This increase was not nearly as large as that found for the more productive and expansive Skagit River estuary where the change in mean increment width had doubled between freshwater and delta habitats. Based upon our preliminary analyses, it appears that mostly wild fish were using the Elwha River estuary and delta, whereas the nearshore catch was dominated by hatchery fish. Thus, competition between hatchery and wild fish may be minimized in the estuary, because the hatchery juveniles appear to largely bypass this habitat in favor the Strait of Juan de Fuca.

\section{References Cited}

Quinn, T.P., 2005, The Behavior and Ecology of Pacific Salmon and Trout: American Fisheries Society, Bethesda, MD, 378 p.

Simenstad, C.A., Fresh, K.L., and Salo, E.O., 1982, The role of Puget Sound and Washington coastal estuaries in the life history of Pacific salmon: An unappreciated function in Kennedy, V.S. (ed.), Estuarine Comparisons: Academic Press, New York, p. 343-364. 


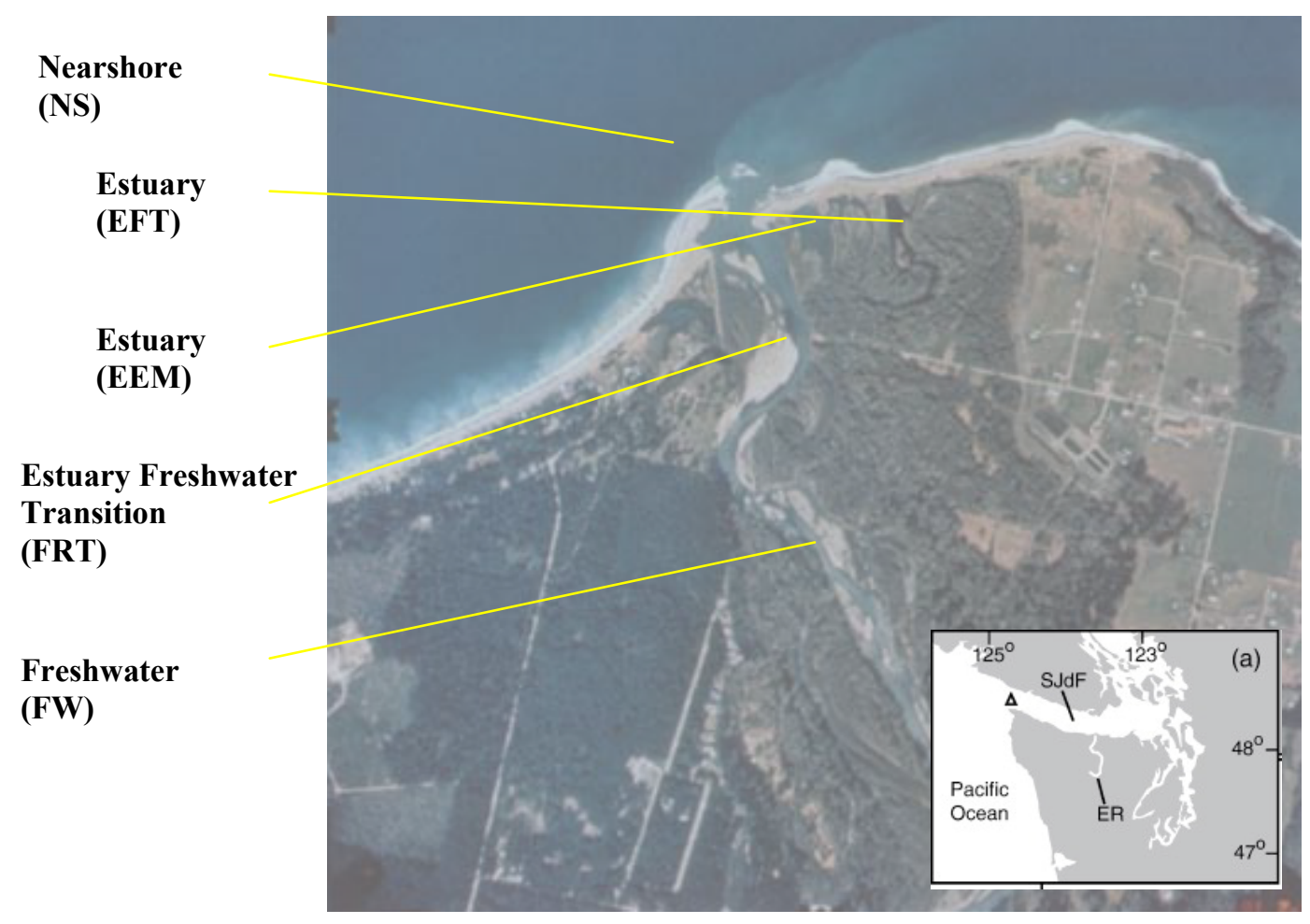

Figure 1. Aerial photograph of the Elwha River with locations of 5 different habitat types (FW $=$ Freshwater, FRT = Forested Riverine Tidal, EFT = Emergent Forested Transition, EEM = Estuarine Emergent Marsh, and NS = Nearshore) sampled for juvenile chinook salmon. Inset (a) shows the regional setting of the Elwha River (ER) and Straits of Juan de Fuca (SJdF).

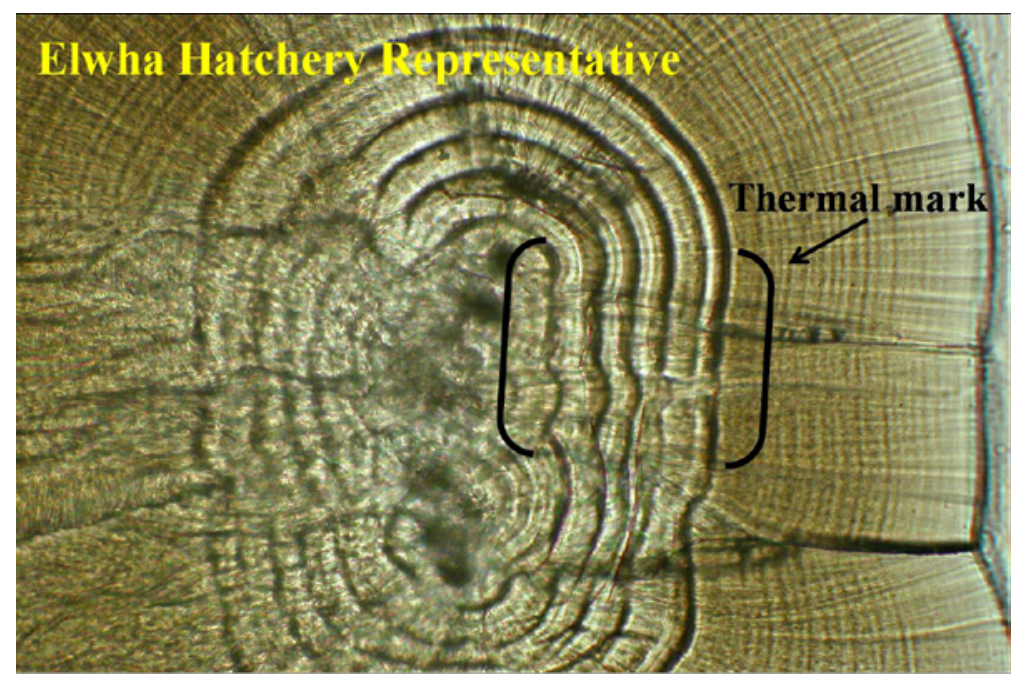

Figure 2. Representative thermally marked otolith from an Elwha hatchery fish collected prior date of release. Brackets highlight the clear and unique marking patterns present due to a thermal marking process that takes place in the hatchery. 


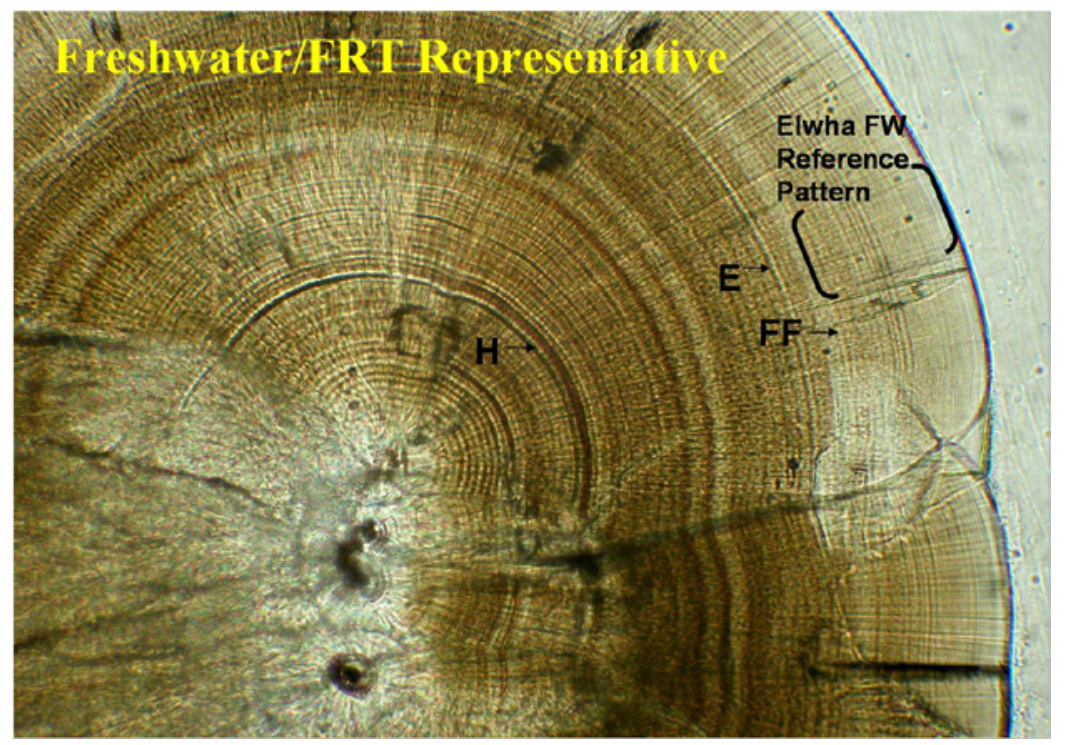

Figure 3. Representative image of an otolith displaying characteristic growth patterns of wild Chinook salmon captured in freshwater/ forested riverine tidal (FRT) habitat. The otolith microstructure depicts points of development $(H=$ hatch, $E=e m e r g e n c e, ~ F F=$ first feed) and a freshwater microstructural pattern used as a reference when analyzing otoliths from fish caught in the other habitats downstream.

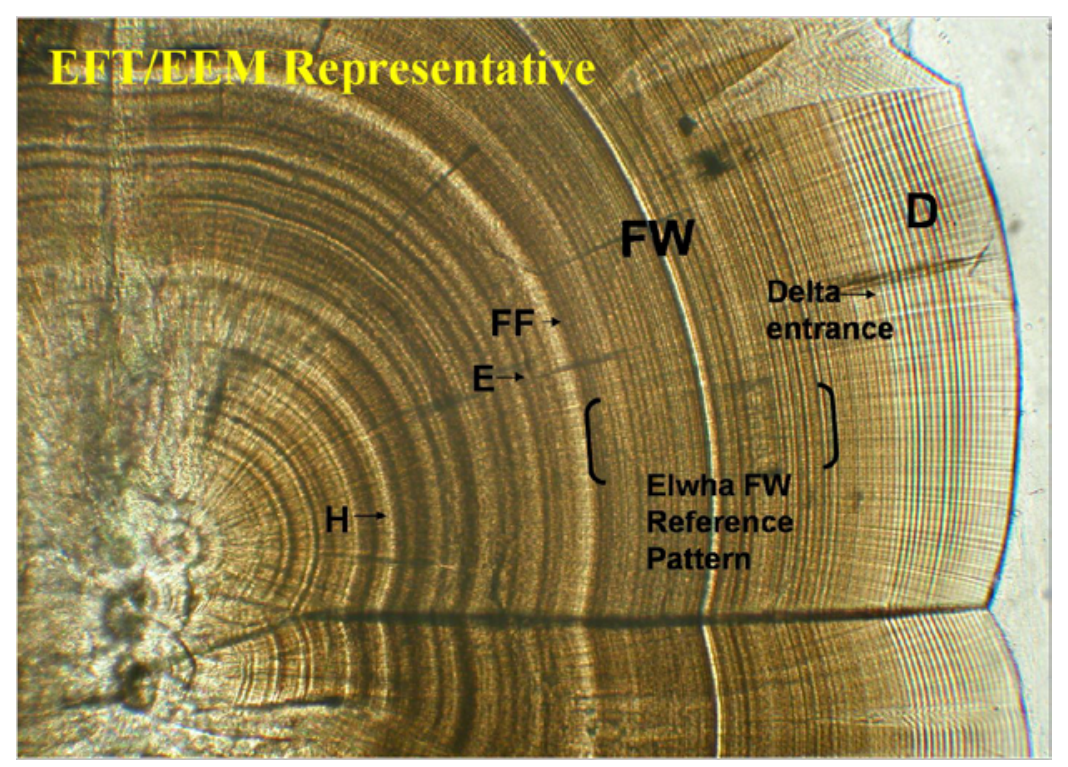

Figure 4. Representative image of an otolith displaying characteristic growth patterns of wild Chinook salmon captured in emergent forested transition and estuarine emergent marsh (EFT/EEM) habitat types. The otolith microstructure depicts points of development ( $\mathrm{H}=$ hatch, $\mathrm{E}=$ =emergence, $\mathrm{FF}=$ first feed) and a freshwater microstructural pattern used as a reference when analyzing otoliths from fish caught in the other habitats downstream, delta entrance, followed by estuary growth (D). 


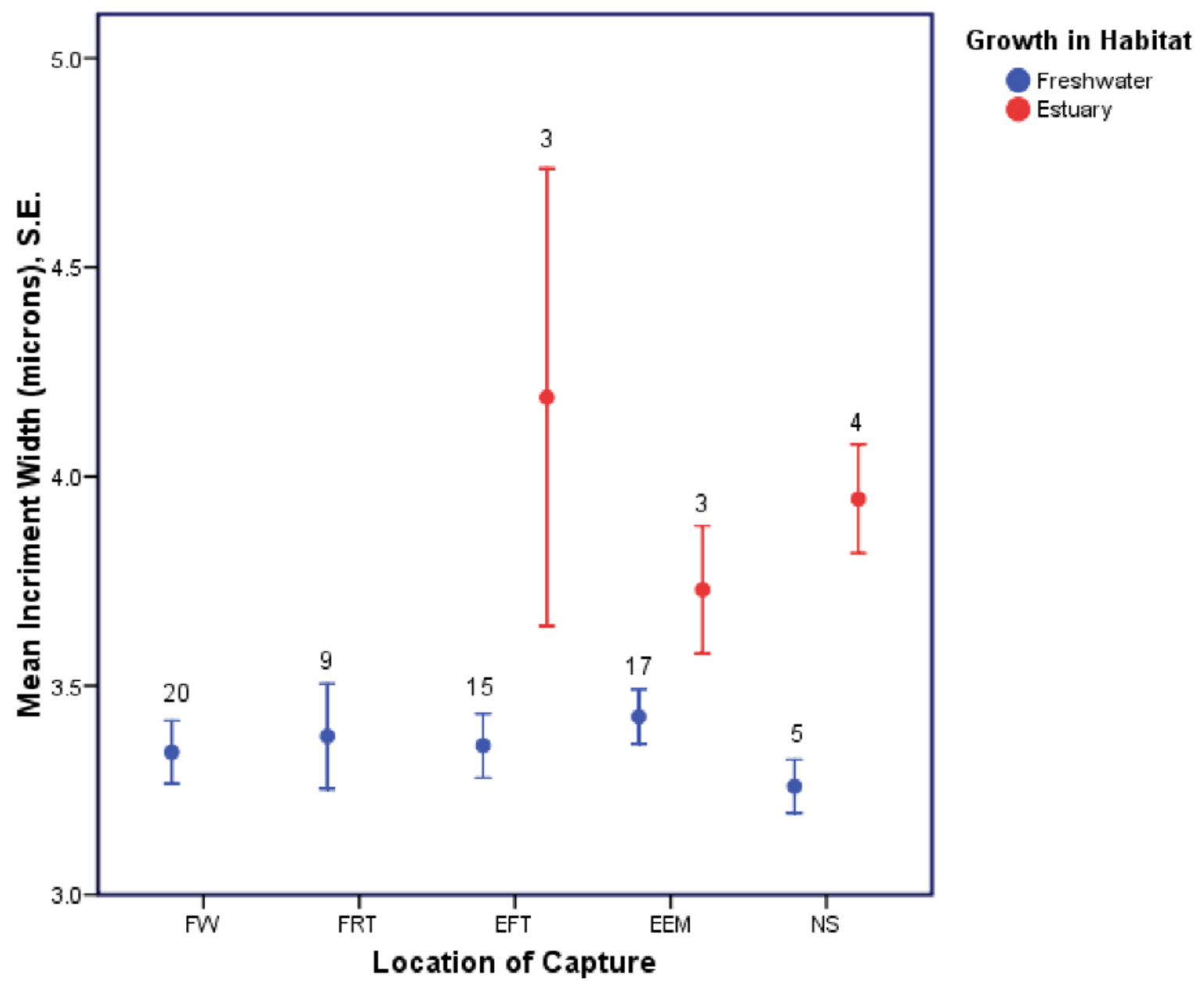

Figure 5. Average daily growth estimates, based upon mean increment width measured from otolith microstructure of wild juvenile Chinook salmon captured from March-October 2006 in the Elwha River. Numbers above bars represent sample sizes for freshwater (FW), forested riverine tidal (FRT), estuarine forested transition (EFT), estuarine emergent marsh (EEM), and nearshore (NS) habitats. 


\title{
Monitoring Sediment and Channel Geometry on the Lower Elwha River, Washington, in Preparation for Dam Removal
}

\author{
By Amy E. Draut ${ }^{1}$, Jonathan A. Warrick², Joshua B. Logan², Randall E. McCoy³, Erin Todd², Michael \\ McHenry ${ }^{3}$, Thomas E. Reiss², David M. Rubin², and Timothy J. Beechie ${ }^{4}$
}

\begin{abstract}
Since 1980, more than 250 dams have been decommissioned and removed in the United States. Most of these were less than $10 \mathrm{~m}$ high and impounded reservoirs less than $105 \mathrm{~m}^{3}$. Although fluvial response to the removal of several small dams has been studied (for example, Bushaw-Newton and others, 2002; Pizzuto, 2002), important gaps remain, indicating the need for landscape-scale case studies of channel response to dam removal. Removal of both of the dams on the Elwha River, scheduled to begin in 2012, will be the largest dam-removal project yet undertaken. Dam removal will restore riparian habitat in a virtually undeveloped watershed, most of which is within Olympic National Park (fig. 1). The Elwha and Glines Canyon Dams, $32 \mathrm{~m}$ and $64 \mathrm{~m}$ high respectively, impound an estimated $13.8 \times 106 \mathrm{~m}^{3}$ of sediment in Lakes Aldwell and Mills (Bureau of Reclamation, 1996).

During the 2-year-long dam-removal process, reservoir sediment will be eroded naturally by the river and transported downstream. Because most effects of renewed sediment delivery are expected within the 7.8-km-long reach downstream of Elwha Dam, we are documenting the existing channel form and sediment characteristics of the Lower Elwha River. Monitoring of channel topography and sediment characteristics focuses on documenting pre-dam-removal conditions and resolving the magnitude of topographic and grain-size changes that occur on seasonal to annual time scales in the dammed system, for future comparison with the river as it adjusts to renewed sediment supply.
\end{abstract}

Key Words: Elwha River, dam removal, sediment transport, fluvial geomorphology

\footnotetext{
1U.S. Geological Survey, Pacific Science Center. 400 Natural Bridges Drive, Santa Cruz, CA, 95060; adraut@usgs.gov

2U.S. Geological Survey, Santa Cruz, CA

${ }^{3}$ Lower Elwha Klallam Tribe, Port Angeles, WA

${ }^{4}$ NOAA Fisheries, Seattle, WA
} 


\section{Monitoring Channel Topography}

We conduct high-resolution topographic surveys in three study reaches along the Lower Elwha River that represent a variety of geographic conditions, distance from the dams, and locations relative to local sediment supply. Each study reach has been surveyed biannually since September 2006 to quantify the effects of winter rain-on-snow floods and spring snowmelt floods on channel form and sediment grain size. An additional reach above both dams, in Olympic National Park, serves as a control reach, because we assume that dam removal will have no effect upstream of the dams. Within each of the three study reaches and the control reach, transects normal to the river banks are 5-15 $\mathrm{m}$ apart and span as great a cross-sectional width as access allows. During each survey, we obtain topographic data using a total-station survey instrument; geodetic control was established in September 2006 by using three Global Positioning System (GPS) receivers within each reach. GPS receivers were referenced back to a base station, which in turn is referenced to a national network of continuously operating GPS receivers.

We plan to survey the four reaches before and after dam removal on a biannual schedule. Spring and fall surveys will resolve seasonal geomorphic and sedimentary variations due to changing flow. We expect that most reworking of sediment and channel form occurs in winter rain-on-snow floods, which typically produce the greatest annual discharge. Following the recommendations of Bushaw-Newton and others (2002) we plan to collect at least two years of baseline data before dam removal; thus, we began surveying in September 2006. Continued monitoring and comparison of the three study reaches and the control reach after dam removal will be used to assess how the river adjusts to landslides in the upper basin because effects on channel form would be superimposed on that of reservoir sediment.

\section{Characterizing Sediment Grain Size}

We expect that fine-sediment transport downstream after dam removal will cause at least temporary filling of pools and bed aggradation, as well as fining of grain sizes in the Lower Elwha River. Most of the river channel presently consists of an armored cobble substrate (Bureau of Reclamation, 1996; Randle, 2003). We are monitoring sediment grain size along the surveyed transects in the three USGS study reaches and in the control reach.

Where sediment is finer than coarse sand, we analyze samples by sieving or settling-tube methods. When sediments are coarser, we use a modified version of the Rubin (2004) autocorrelation algorithm to obtain mean grain size from digital photographs. This method involves photographing sediment from an angle orthogonal to the bed with a digital camera ('CobbleCam') mounted on a tripod. When vegetation is sparse or absent, this technique provides a rapid, efficient means to characterize surface sediment grain size along the surveyed transects and, thus, a way to quantify changes in habitat and channel characteristics before and after dam removal. When vegetation is present on the substrate, the CobbleCam grain-size analysis is biased toward coarser sizes. 


\section{Channel Migration Inferred from Aerial Images}

We quantified rates and patterns of lateral channel migration in the dammed system using historical channel boundaries interpreted from geo-referenced aerial photographs. The Lower Elwha Klallam Tribe provided these nine sets of images, which date from 1939 to 2003.

We digitized historical channel boundaries into GIS for spatial analysis, using the DSAS (Digital Shoreline Analysis System) ArcGIS software extension created by the USGS. We compared the historical positions of the western edge of the river channel to an arbitrary parallel baseline along transects spaced at 100-m intervals from Elwha Dam to the river mouth.

The lower river channel form changes rapidly and substantially. The main channel underwent total lateral movement of about 40-400 m across the floodplain between 1939 and 2003. Net motion relative to the 1939 position ranged from $0-410 \mathrm{~m}$. The greatest annualized migration rates occurred between photographs taken in 1977 and 1981 and probably result from two winter floods that were the largest discharge events between 1955 and 1990.

We expect that reservoir sediment input will cause aggradation and fining of the bed below the dams. The lower river may respond to the new sediment influx by changing from an anabranching channel to a more braided system and back. These channel changes would occur as the pulse of sediment is accommodated and a new equilibrium reached over several decades (Bureau of Reclamation, 1996; EIS, 1996). Such responses have occurred in other fluvial systems that experienced increased sediment load (Wohl and Cenderelli, 2000; Doyle and others, 2002; Xu, 2002; Grant and others, 2003; Randle, 2003). However, details of the local magnitude, spatial distribution, and longevity of channel-bed aggradation that may occur are unknown. The accuracy of predicting specific local responses depends not only on channel geometry but also on the timing and magnitude of river flows following sediment input (for example, Wohl and Cenderelli, 2000). Present and future studies on the Elwha River thus provide an unprecedented opportunity to study the fluvial and coastal response to a large, regulated influx of sediment on a watershed scale and to assess the predictive capability of widely used models of fluvial evolution.

\section{References Cited}

Bureau of Reclamation, 1996, Sediment analysis and modeling of the river erosion alternative, Elwha River Restoration Project, Washington: Elwha Technical Series PN-95-9, U.S. Department of the Interior, Bureau of Reclamation, Pacific Northwest Region, Boise, Idaho, August 1996.

Bushaw-Newton, K.L., Hart, D.D., Pizzuto, J.E., Thomson, J.R., Ashley, J.T., Johnson, T.E., Horwitz, R.J., Keeley, M., Lawrence, J., Charles, J., Gatenby, C., Kreeger, D.A., Nightengale, T., Thomas, R.L., and Velinsky, D.J., 2002, An integrative approach to understanding ecological responses to dam removal: the Manatawny Creek study: Journal of the American Water Resources Association, v. 38, no. 6, p. 1581-1600.

Doyle, M.W., Stanley, E.H., and Harbor, J.M., 2002, Geomorphic analogies for assessing probable channel response to dam removal, Journal of the American Water Resources Association, v. 38, no. 6, p. 1567-1579. 
Environmental Impact Statement (EIS-2): Implementation EIS, 1996, Elwha River Ecosystem Restoration Implementation Final Environmental Impact Statement (National Park Service, U.S. Fish and Wildlife Service, Bureau of Reclamation, U.S. Bureau of Indian Affairs, U.S. Army Corps of Engineers, and Lower Elwha Klallam Tribe), November 1996.

Grant, G.E., Schmidt, J.C., and Lewis, S.L., 2003, A geological framework for interpreting downstream effects of dams on rivers: Water Science and Application, v. 7, p. 209-225.

Pizzuto, J.E., 2002, Effects of dam removal on river form and process: BioScience, v., 52, no. 8, p. 683-691.

Randle, T.J., 2003, Dam removal and sediment management, Dam Removal Research: Status and Prospects, in Graf, W.L. ed., Washington, D.C., H. John Heinz III Center, p. 81-104.

Rubin, D.M., 2004, A simple autocorrelation algorithm for determining grain size from digital images of sediment: Sedimentology, v. 74, no. 1, p. 160-165.

$\mathrm{Xu}$, J., 2002, Complex behaviour of natural sediment-carrying streamflows and the geomorphological implications: Earth Surface Processes and Landforms, v. 27, p. 749-758.

Wohl, E.E., and Cenderelli, D.A., 2000, Sediment deposition and transport patterns following a reservoir sediment release: Water Resources Research, v. 36, no. 1, p. 319-333.

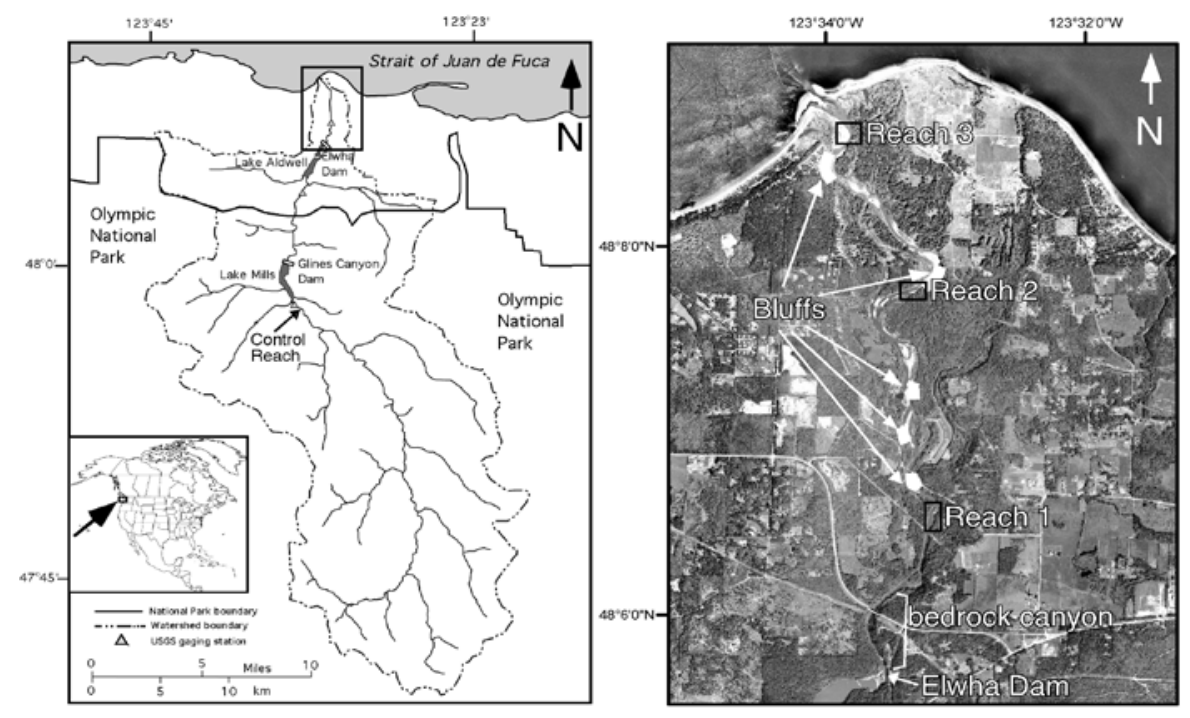

Figure 1. (A) Map of the Elwha River watershed, Washington, USA. The box outlines the area shown in B. (B) Aerial photograph taken in 2003 showing the river below Elwha Dam. The three study reaches and one control reach are indicated. White bars in (B) mark sediment-producing bluffs. 


\title{
Effects of Urbanization on Nearshore Processes and Ecosystems: Liberty Bay
}

By Renee Takesue ${ }^{1}$, Jessie Lacy², Rick Dinicola ${ }^{3}$, Ray Watts ${ }^{4}$, Vivian Queija ${ }^{5}$, Dennis Rondorf6, Theresa Liedtke $^{6}$, and Paul Hershberger ${ }^{7}$

\begin{abstract}
Urban land use and development alters natural physical and biogeochemical inputs, transports, and transformations in the watershed and at the shore. Such altered processes may, in turn, change the structure and function of nearshore ecosystems (fig. 1). The goals of the Urbanization task are (1) to understand fundamental processes, such as land use or physiochemical inputs, in the nearshore of urban areas; (2) to describe habitat structure and function, such as substrate or food web dynamics, in impacted areas; (3) to identify impact mechanisms (bold arrows), such as anthropogenic eutrophication, that lead to impaired ecosystems and processes; and (4) to provide decision-making tools, such as predicted ecological impacts of a given urban stressor, to natural resource managers and policy makers. We began a pilot study to test the assumptions and linkages of our disturbance conceptual model. Study objectives were to describe nearshore habitat structure and function, to identify potential stressors (unnatural disturbances) and impaired processes, and to develop quantitative urban metrics. During the first year of study we gained a better understanding of freshwater-seawater mixing in Liberty Bay; of temperature, nutrient, and phytoplankton variations during April-May; of bottom sediment metal and wastewater chemical concentrations; of wastewater nitrogen uptake in Liberty Bay; and quantitatively compared two urban metrics to ecological indicators.
\end{abstract}

Key Words: Urbanization, contaminants, forage fish

\footnotetext{
1U.S. Geological Survey, Coastal \& Marine Geology, 400 Natural Bridges Dr., Santa Cruz, CA; rtakesue@usgs.gov

2U.S. Geological Survey, Santa Cruz, CA

3U.S. Geological Survey, Tacoma, WA

${ }^{4}$ U.S. Geological Survey, Fort Collins, CO

5U.S. Geological Survey, Seattle, WA

6 U.S. Geological Survey, Cook, WA

${ }^{7}$ U.S. Geological Survey, Nordland, WA
} 


\section{Pilot Study}

We conducted a first-year pilot study in a small embayment to maximize the likelihood of detecting contaminant signals and associated ecosystem impacts. The residence time of water in embayments is longer than at the open coast, resulting in less dilution of contaminants and longer exposure of sediment and organisms to contaminants. Our ecological endpoint for the pilot study was forage fish success, specifically herring (Clupea harengus pallasi) spawning success. Using data from the Washington Department of Fish and Wildlife, we identified several small embayments that have known forage fish spawning sites or are near spawning. Studied embayments included Chambers Creek, Wollochet Bay, Quartermaster Harbor, Liberty Bay, Hidden Cove, and Port Gamble. Of these, Liberty Bay was the only site that had a sufficient degree of urbanization. There was an alongshore gradient in urban development from the city of Poulsbo out to Point Bolin (fig. 2).

Because Washington Department of Fish and Wildlife data showed that herring spawned around Point Bolin but not in Liberty Bay, we characterized the nearshore to assess whether the absence of herring spawning in Liberty Bay could be attributed to a lack of suitable spawning habitat, specifically eelgrass (Zostera marina). A quantitative urban metric was developed based on shoreline parcel density that could be correlated with herring spawning and other ecological endpoints (Watts and Queija, this volume).

Sewage inputs from leaking municipal sewer lines and privately-owned septic systems are a known stressor in Liberty Bay. Coliform bacteria levels are elevated following sewage spills, and the Kitsap County Health District advises against contact with the water or shellfish harvesting for several days following spills. Wastewater indicator chemicals in sediment showed that Liberty Bay was clearly impacted by wastewater near the town of Poulsbo (Takesue and Dinicola, this volume). The impact was still apparent near the mouth of Liberty Bay, but less so.

Much of the shoreline of Liberty Bay has been hardened with riprap or bulkheads. The next phase of the pilot study will explore relationships between shoreline armoring, beach characteristics, and upper beach use by beach-spawning forage fish.

\section{Acknowledgments}

The Urbanization Team thanks Paul Dorn, Suquamish Tribe Fisheries Biologist; Daniel Penttila, WDFW Forage Fish Program; and Luis Barrantes, Liberty Bay Foundation Volunteer Coordinator for invaluable logistical and operational support and scientific expertise.

\section{References Cited}

Takesue, R., and Dinicola, R, This volume, Eelgrass, bottom sediment, nutrients, and wastewater contaminants in Liberty Bay: Coastal Habitats in Puget Sound (CHIPS) 2006 Workshop Report: U.S. Geological Survey Open-File Report 2009-1218.

Williams, G.D., and Thom, R.M., 2001, Marine and estuarine shoreline modification issues. White paper submitted to WA Dept. Fish \& Wildlife, WA Dept. Ecology, WA Dept. Transportation. Prepared by Battelle Memorial Institute.

Watts, R.D, and Queija, V., This volume, Urban metrics correlated with reduced herring spawn in Liberty Bay and Port Orchard, Puget Sound, Washington: Coastal Habitats in Puget Sound (CHIPS) 2006 Workshop Report: U.S. Geological Survey Open-File Report 2009-1218. 


\section{Disturbance conceptual model}

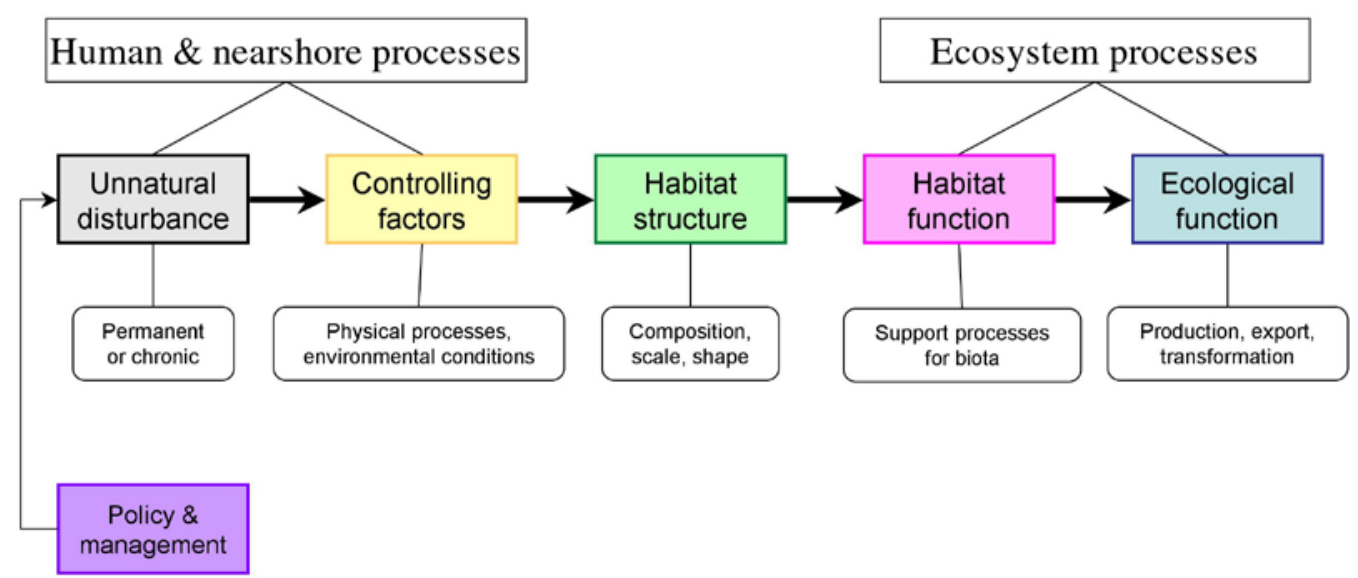

Figure 1. Conceptual diagram of the mechanisms by which an unnatural disturbance interacts with controlling factors and impacts nearshore ecosystems (after Williams and Thom, 2001). 


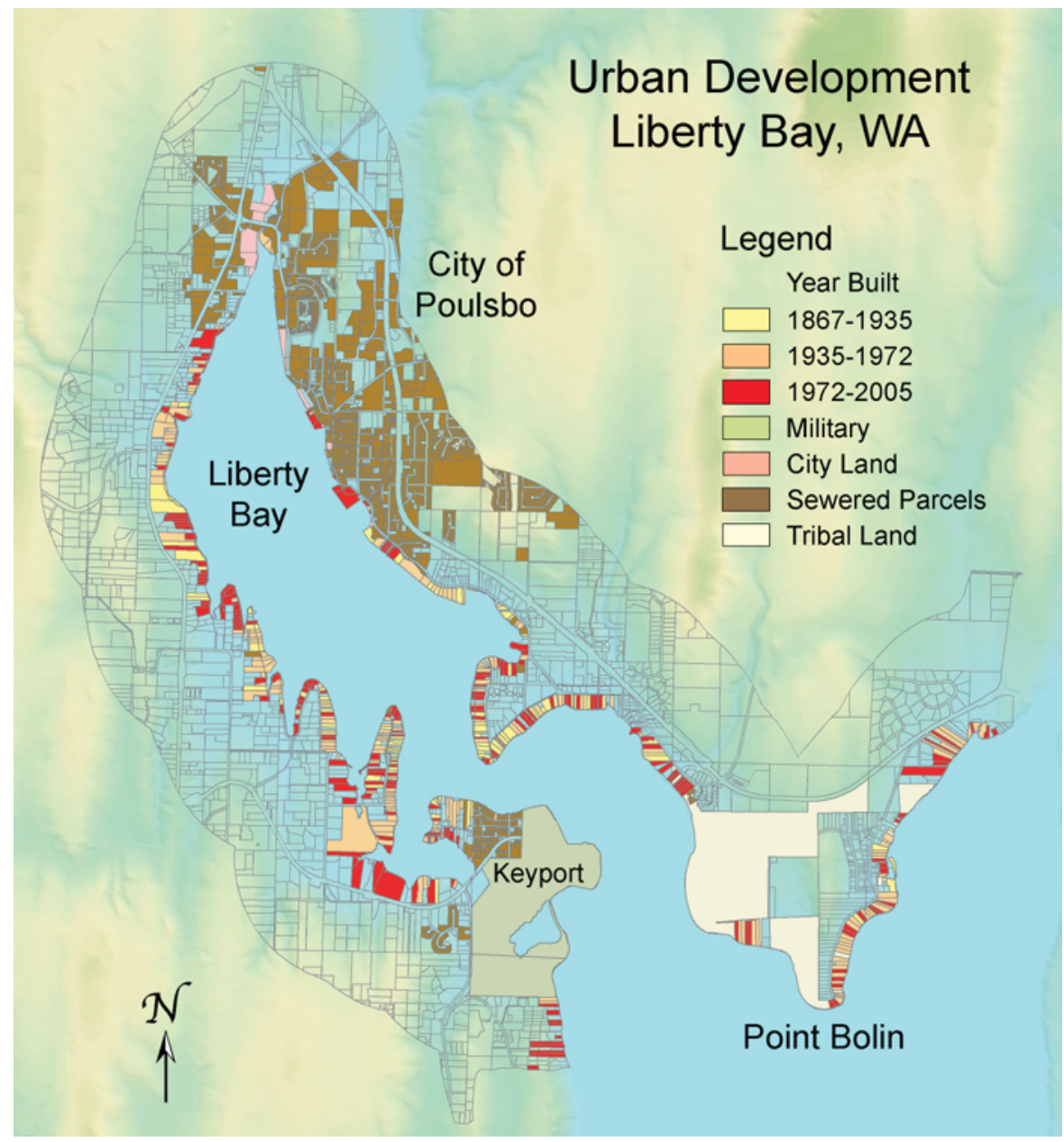

Figure 2. Parcels (gray lines) around the shore of Liberty Bay are narrow and closely spaced, typical of urban density. Colors show the year built, land ownership, and sewered parcels. Three fourths of the parcels within $1 \mathrm{~km}$ of the shore use septic systems. The distance from the City of Poulsbo to Point Bolin is $6.5 \mathrm{~km}$. 


\title{
Urban Metrics Correlated with Reduced Herring Spawn in Liberty Bay and Port Orchard, Puget Sound, Washington
}

\author{
By Raymond D. Watts ${ }^{1}$ and Vivian Queija ${ }^{2}$
}

\begin{abstract}
We present preliminary evidence that quantitatively links shoreline development to reduction of herring (Clupea harengus pallasi) spawn (observed egg deposits) in the Liberty Bay - Port Orchard section of Puget Sound (fig. 1). Using data from Kitsap County and from the Washington State Departments of Natural Resources and Fish and Wildlife (Berry and others, 2001), we associated indicators of shoreline development with sample points every $100 \mathrm{~m}$ along the shoreline of the study area $(\mathrm{N}=577)$. We evaluated statistical relationships of these indicators to presence or absence of offshore herring spawn within $125 \mathrm{~m}$ of each sample point. Our working hypothesis was that shoreline development reduces the probability of observed spawn. Preliminary results showed that herring spawning had the highest (negative) correlation with shoreline development over $1 \mathrm{~km}$ stretches of shore. The greatest population of parcel densities was in the range 30 to 60 parcels per kilometer.
\end{abstract}

Key Words: Urbanization, Herring, Shoreline

\section{Urban Metric Development and Analysis}

We used two types of development indicators: (1) fraction of shoreline with physical modification (bulkheads, riprap, piers, jetties, etc.), and (2) counts of shoreline ownership parcels in circles of various radii $(50,100,200,500$, and $1,000 \mathrm{~m})$ centered on the sample points.

The shoreline physical modification indicator showed no significant correlation with herring spawn $\left(\mathrm{R}^{2}=0.02\right)$. Thus, our analysis provides no evidence that physical modification adversely affects herring, but we do not rule out that possibility. The observed low correlation is validly attributable to shoreline modification that is so common that other factors determine the presence or absence of herring spawn. Shoreline modification may generally suppress spawn, but is likely to affect other species to a greater degree than herring, particularly those species that spawn on the beach rather than in intertidal and subtidal waters.

1U.S. Geological Survey, Fort Collins Science Center, 2150 Centre Ave Bldg C, Fort Collins CO 80526-8118; rwatts@usgs.gov 2U.S. Geological Survey, Seattle, WA 
We estimated shoreline development density by counting parcels that were partly or entirely within $100 \mathrm{~m}$ of shore. This was done by generating a $100 \mathrm{~m}$ "bathtub ring" on land, and then using this ring to cookie cut parcels, thus eliminating parcels and parcel fragments that were either in water or more than $100 \mathrm{~m}$ inland. We consolidated remaining parcel fragments by tax account number and eliminated public parcels (parks, roads, etc.). The centroids of remaining parcels closely represent commercial and residential development, because few undeveloped parcels remain in this part of Puget Sound. Counting centroids in circles of various radii yields development indicators at multiple spatial resolutions.

Of the parcel density indicators, the $500 \mathrm{~m}$ version — which measures development along approximately $1 \mathrm{~km}$ of shoreline - had the highest (negative) correlation with herring spawn (fig. 2 ). This result suggests that herring respond to conditions along approximately a kilometer of shoreline, either by physical mixing of influences over that distance or by the mobile fish themselves responding to conditions over that range.

Figure 3A shows the distribution of parcel densities measured with the $500 \mathrm{~m}$ search radius. The probability of herring spawn diminishes as parcel density increases (fig. $3 \mathrm{~B}$, discrete points). A logistic regression model of this probability variation (fig. 3B, continuous curve) indicates that the most sensitive parcel density is around 50 parcels $/ \mathrm{km}$. The greatest population of parcel densities is in the range 30 to 60 parcels / km (fig. $3 \mathrm{~A}$ ), indicating that much of the shoreline in this section of Puget Sound is poised for significantly diminished herring spawn probability if development density is increased. Figure $3 \mathrm{C}$ shows application of the logistic regression model to the current distribution of development density; the expected spawn probability distribution divides the shoreline nearly in half between areas of spawn and no spawn.

Spawn losses can be estimated for various scenarios of shoreline development density by applying the probability model in the same way that it has been applied in figure 3C. For example, if 10 parcels are added everywhere per $\mathrm{km}$ of shoreline (this unlikely scenario shifts the development density histogram one column to the right), then calculations show an expected loss of 18 percent of current spawn zone.

When processes that connect development to spawn are better understood, it may be possible to design and build shoreline development with less impact on herring. To achieve zero additional impairment, the probability curve needs to shift to the right — indicating diminished spawn sensitivity - at the same rate as the histogram of development density.

The analysis presented here was specific to a limited area of Puget Sound. It is possible that the statistical associations documented for this area have underlying local geographic causes, invalidating the model for application elsewhere. Further work will expand the geographic area of analysis to see whether similar results apply more broadly across Puget Sound.

\section{References Cited}

Berry, H.D., Harper, J., Mumford, T.F., Jr., Bookheim, B.E., Sewell, A.T., Tamayo, L.J., 2001, The Washington State ShoreZone Inventory User's Manual: Olympia, Washington, Washington State Department of Natural Resources. 


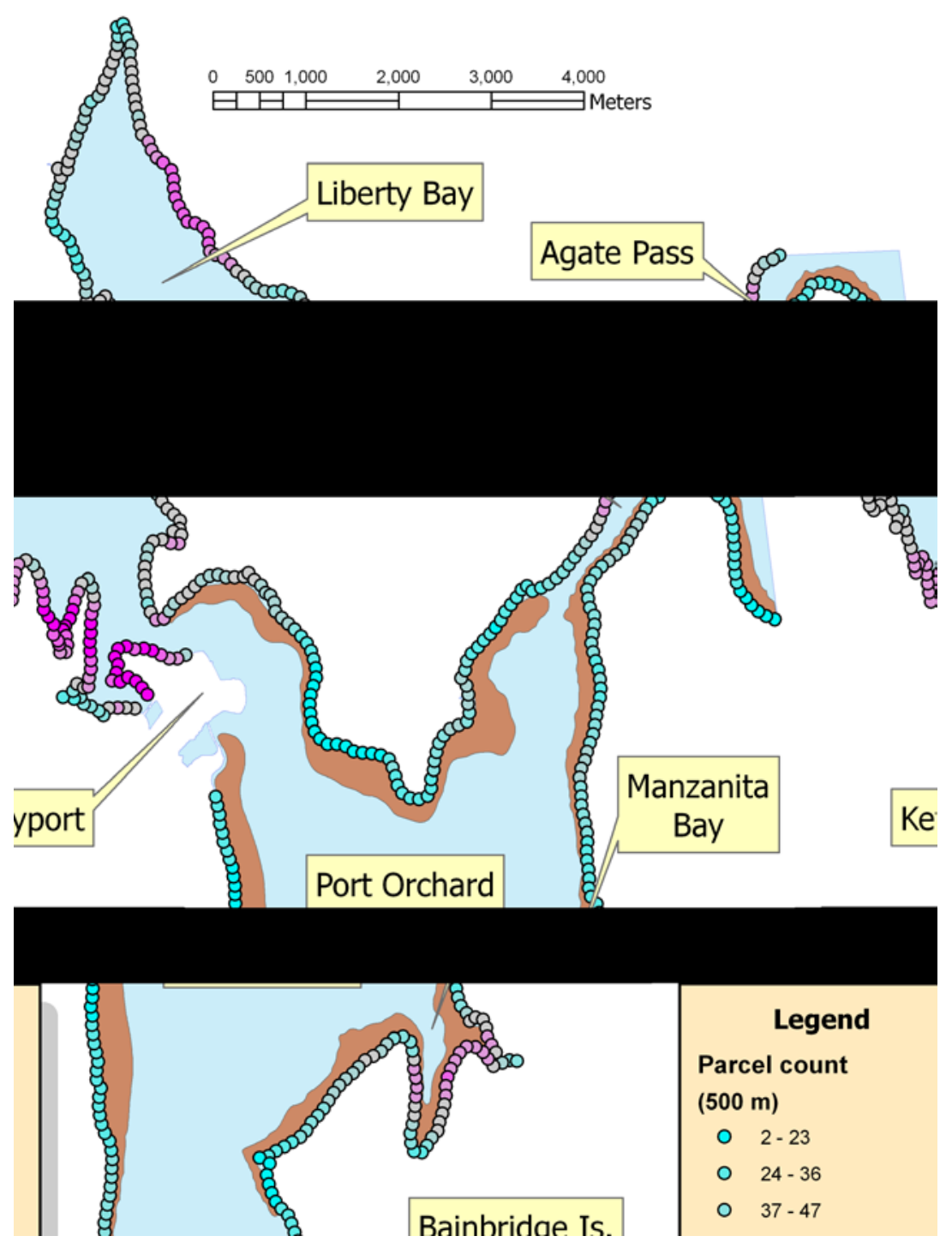

Figure 1. Map of area of investigation in central Puget Sound. The 577 sample points are colored according to the number of ownership parcels within a $500 \mathrm{~m}$ radius. 


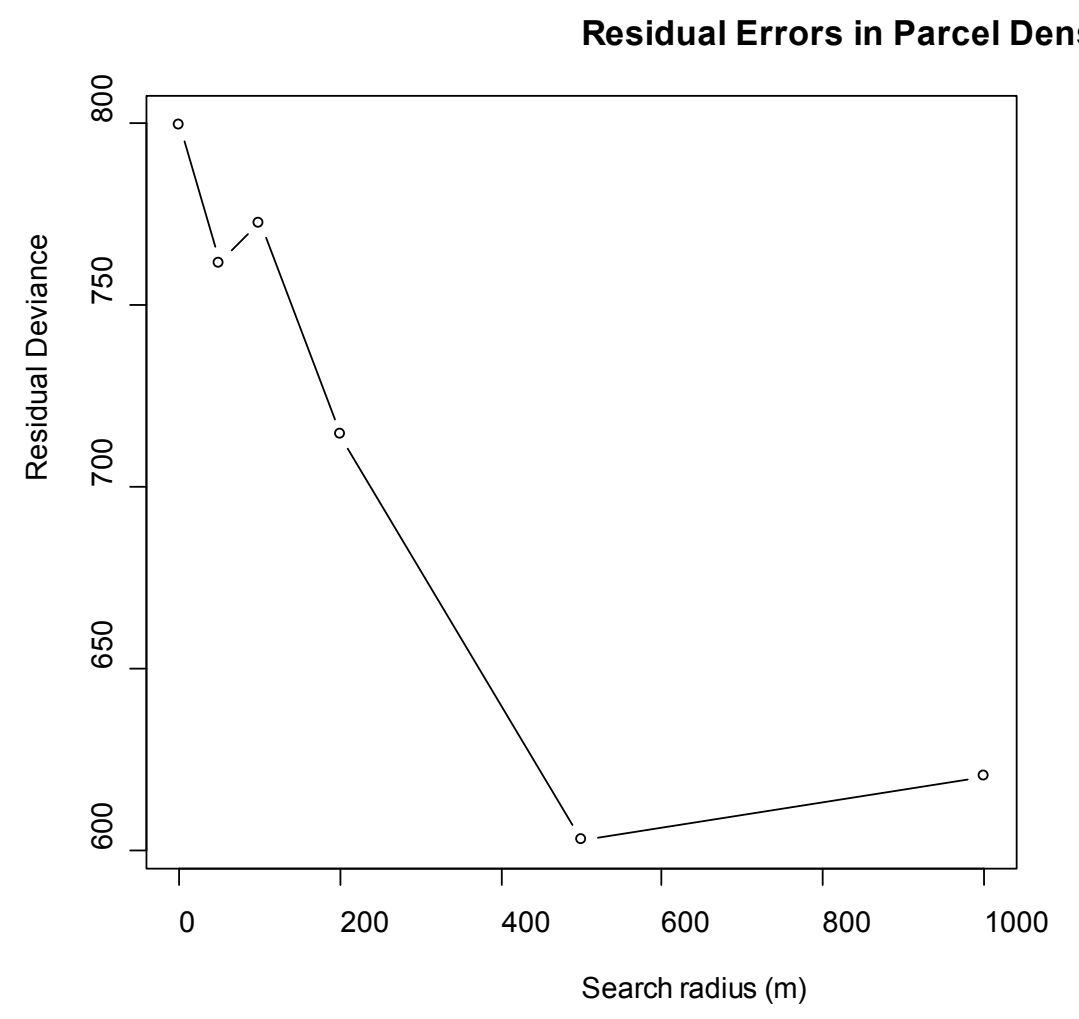

Figure 2. Residual errors for single variable logistic regression models of spawn probability based on parcel density. Parcel density measured at $500 \mathrm{~m}$ radius has lowest model error (greatest predictive value). Zero radius is the model based on mean probability, with no parcel density dependence. 


\section{Ownership parcels / km}

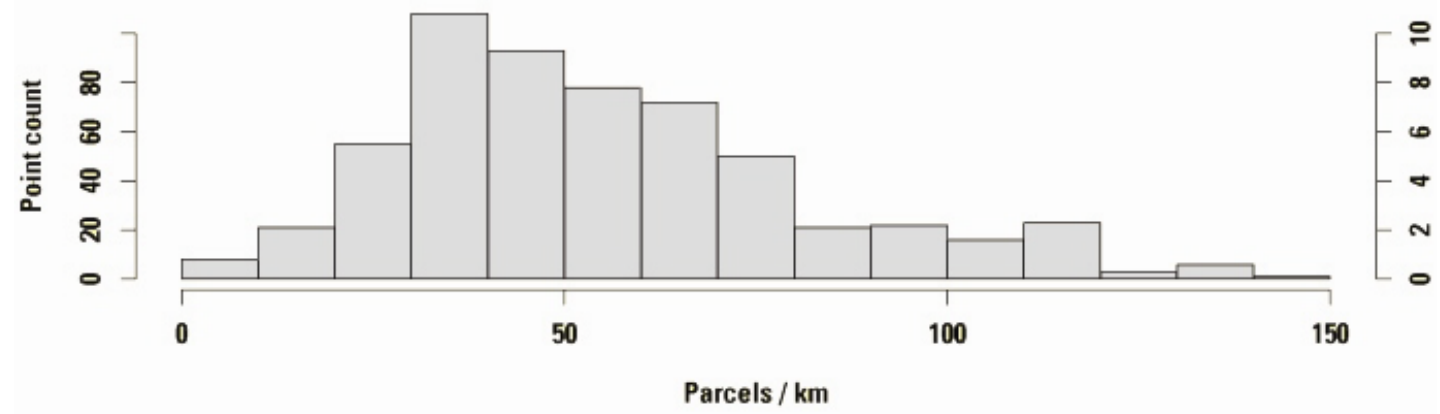

Herring spawn probability

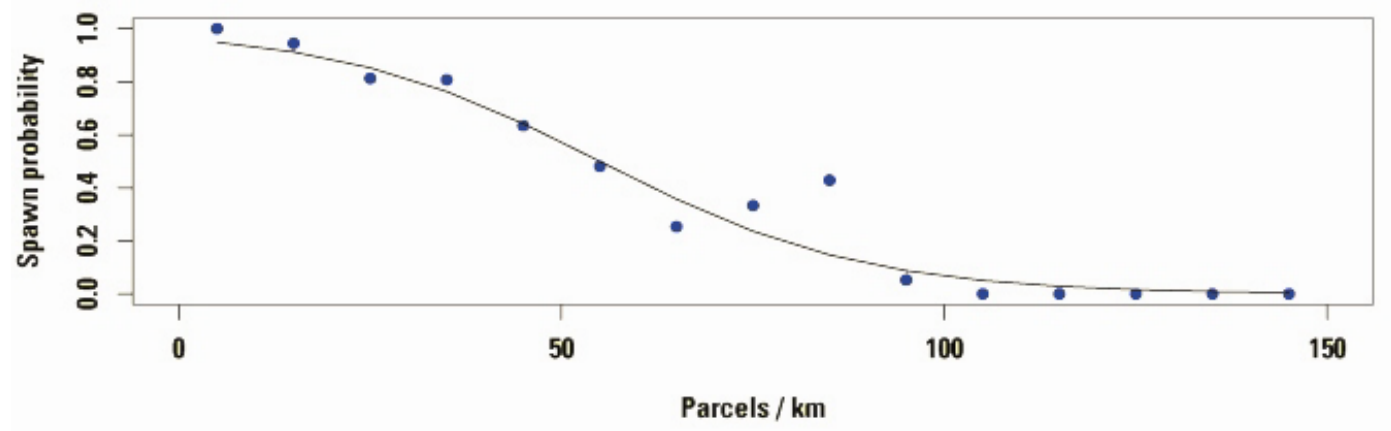

Spawn suppression

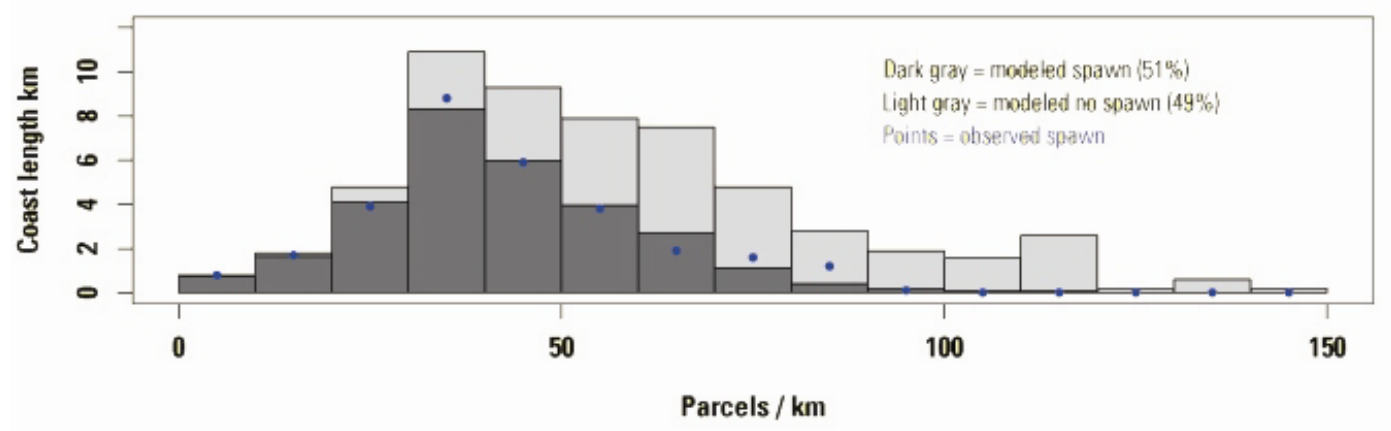

Figure 3. Panel A, top: distribution of parcel densities; the scale at right translates point counts to shoreline length (100 m/ sample point). Panel B, center: observed (points) and modeled (curve) probability of herring spawn as a function of parcel density. Panel C, bottom: probability model applied to observed parcel density distribution. 


\title{
Temporal Variability in Salinity, Temperature, and Chlorophyll a in Liberty Bay, Washington
}

By Jessie Lacy ${ }^{1}$ and Rick Dinicola²

\begin{abstract}
As part of the pilot study of the effects of urbanization in Liberty Bay, we deployed two moorings to collect time series of hydrographic properties (fig. 1). These data were collected to evaluate the residence time of water in Liberty Bay, and the degree of mixing between Liberty Bay and adjacent waters. A second objective was to document changes in properties critical to aquatic ecology (salinity, temperature, and phytoplankton concentration) over the course of the spring, to support interpretation of other data collected in the pilot study. We measured temperature, salinity, suspended sediment concentration, and fluorescence continuously (every 10 minutes) in the middle of Liberty Bay and outside Liberty Bay at Point Bolin during AprilMay at 1 meter below the surface. Surface temperatures increased from $10^{\circ}$ to $14^{\circ} \mathrm{C}$ during the deployment, and were 1-2 degrees higher inside Liberty Bay than at Pt. Bolin. Salinities were between 28 and 29 parts per thousand (ppt) with little spatial or temporal variability, indicating that freshwater inflows to Liberty Bay do not have a widespread influence on salinity (fig. 2).

We measured fluorescence of chlorophyll $a$ to determine temporal variability of phytoplankton concentration. Water samples were taken weekly, filtered in the field, and analyzed in the laboratory to calibrate the fluorometers. Fluorescence varied on daily and weekly-to-biweekly timescales. Daily fluctuations (not shown) are most likely caused by inverse yield of fluorescence with solar irradiance (known as fluorescence quenching) rather than changes in chlorophyll concentration, while the biweekly variations are caused by phytoplankton bloom dynamics. Nutrients were measured weekly during April and May in samples from $1 \mathrm{~m}$ below the surface and $1 \mathrm{~m}$ above the bottom. Nutrient concentrations decreased significantly during the study, likely due to uptake by phytoplankton (fig. 3). The nutrient and chlorophyll trends suggest that high nutrient concentrations in early spring enhance phytoplankton production in Liberty Bay.

To complement the time series data, we collected water column profiles of temperature, salinity, suspended sediment concentration, and fluorescence along the axis of Liberty Bay out to Pt. Bolin in late April. With the profiling data, we evaluated the influence of vertical and horizontal concentration gradients on temporal variability at the two moorings.
\end{abstract}

Key Words: Temperature, salinity, fluorescence, chlorophyll $a$, nutrients

1U.S. Geological Survey, Western Coastal and Marine Geology, 400 Natural Bridges Dr., Santa Cruz, CA; jlacy@usgs.gov

2U.S. Geological Survey; Tacoma, WA 


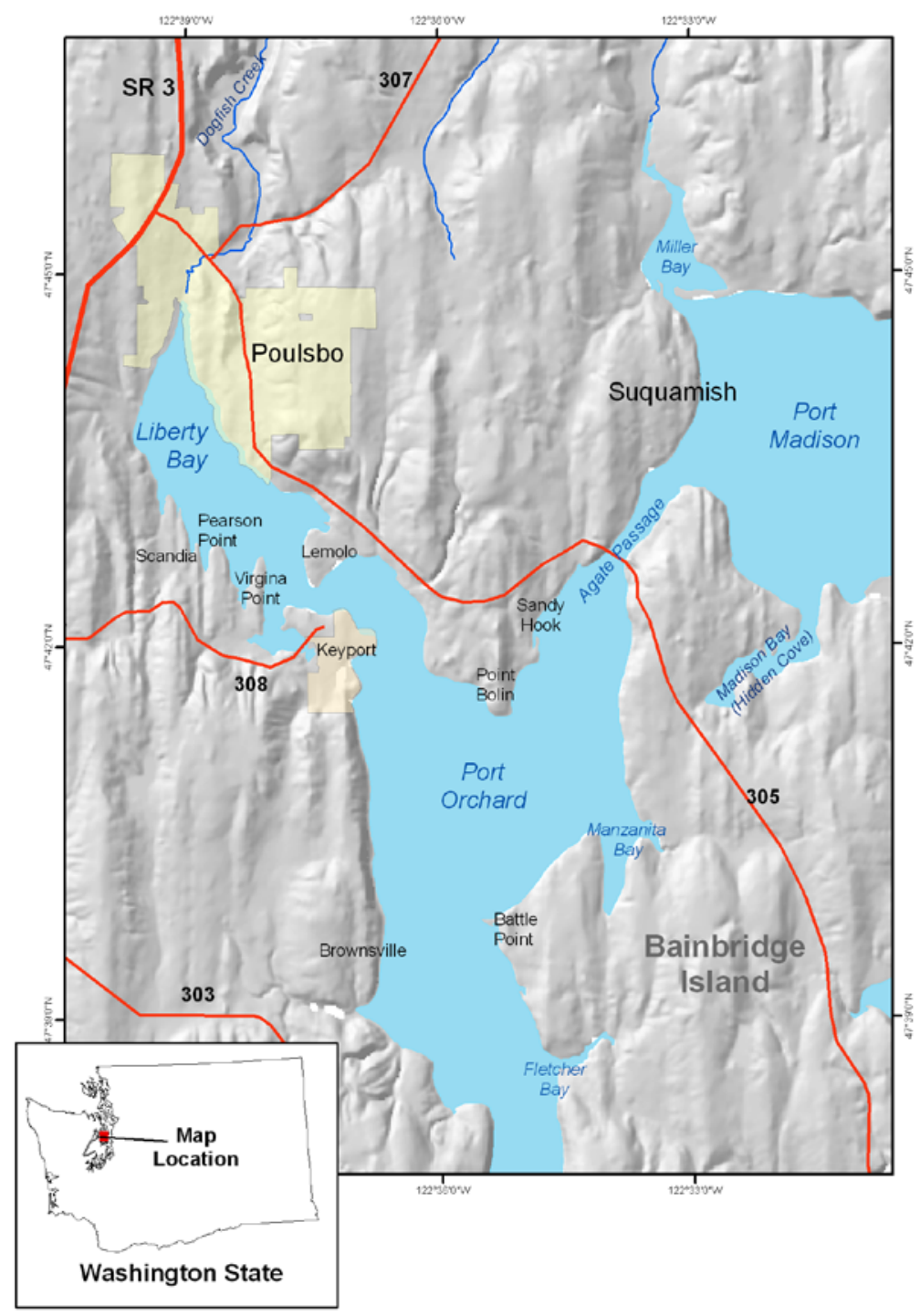

Figure 1. Site map and location of Liberty Bay, Washington. Data were collected in the middle of Liberty Bay and outside Liberty Bay at Point Bolin during April-May at 1 meter below the surface. 

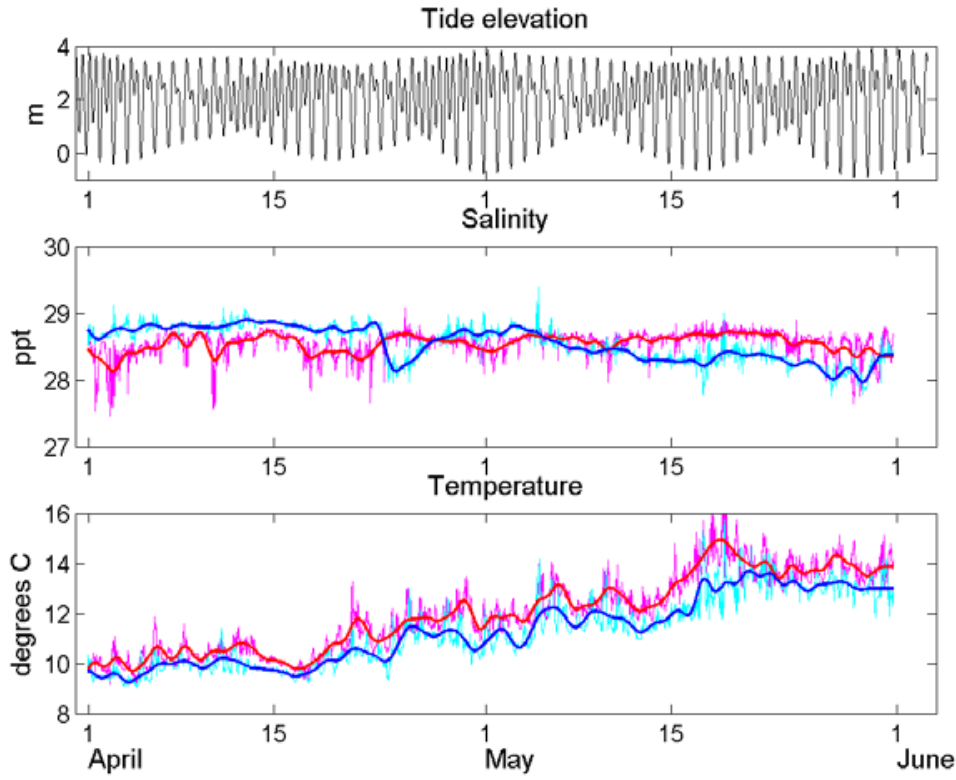

Figure 2. Predicted tidal elevation and measured salinity and temperature inside Liberty Bay (red) and at Point Bolin (blue). Thin lines are measurements at 10-minute intervals; thick lines are tidal averages.
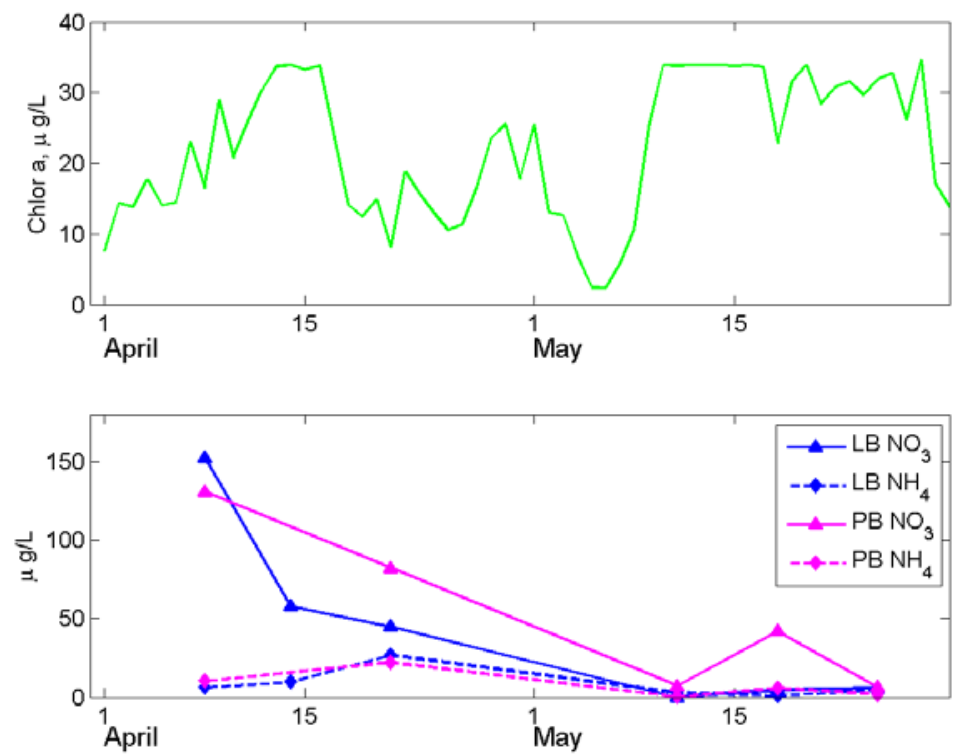

Figure 3. Chlorophyll a concentrations within Liberty Bay, and near-surface nitrate $\left(\mathrm{NO}_{3}\right)$ and ammonium $\left(\mathrm{NH}_{4}\right)$ concentrations in Liberty Bay and at Point Bolin. Chlorophyll a concentrations are subsampled once every 24 hours, at midnight, and nutrient concentrations were measured weekly. Maximum calibrated chlorophyll a concentrations is $35 \mu \mathrm{g} / \mathrm{L}$; fluorescence values above the calibrated range are shown as 35 $\mu \mathrm{g} / \mathrm{L}$. 


\title{
Eelgrass, Bottom Sediment, Nutrients, and Wastewater Contaminants in Liberty Bay, Washington
}

\author{
By Renee Takesue ${ }^{1}$ and Rick Dinicola²
}

\begin{abstract}
A pilot study with two goals was executed in Liberty Bay, Washington. The first goal was to describe geochemical properties in Liberty Bay and at Point Bolin to assess the suitability of the nearshore region as habitat for eelgrass (Zostera marina) and herring (Clupea harengus pallasi). The second goal was to understand biogeochemical processes associated with urbanization. We described characteristics of nearshore bottom sediments, determined the spatial distribution of eelgrass, and measured water column properties. Bottom sediment texture reflects sediment sources and modification by the physical energy environment. Sediment texture, in turn, controls benthic community structure and habitat use: eelgrass requires soft sediment (sand or mud) for rhizome growth; herring spawn on eelgrass. Sediment oxidation-reduction potential (redox) was evaluated as a habitat characteristic because highly reducing sediments produce sulfide, which may inhibit eelgrass growth (Terrados and others, 1999).

Water column characteristics were expected to show whether anthropogenic eutrophication (nutrient loading) occurred in Liberty Bay, the degree of nutrient uptake by primary producers, and, if eutrophication occurred, whether it resulted in low oxygen (hypoxic) bottom waters, which negatively impact organisms (fig. 1). We also measured wastewater contaminants in Liberty Bay sediments.
\end{abstract}

Key Words: Eelgrass, grain size, redox, nutrients, contaminants

\section{Methods}

Eelgrass beds were surveyed at low tide in April 2006 at 10 randomly chosen sites along a $100 \mathrm{~m}$ alongshore transect, when possible. We measured shoot density, leaf length and width, and rhizome internode lengths.

We collected surface sediment samples throughout Liberty Bay and around Point Bolin (fig. 2) in April 2006, with a stainless steel petite ponar benthic grab sampler deployed from a small boat. We subsampled for grain size, total sedimentary metals, and sedimentary polycyclic aromatic hydrocarbons (PAHs). We collected two short push cores (15 cm-long), one from mudflats near the city of Poulsbo at the head of Liberty Bay and the other from Point Bolin.

We measured sediment redox, total sedimentary metals, and grain size at 1-cm intervals in each core. To assure the integrity of sediment redox measurements, we processed sediment cores in an oxygen-free environment $\left(\mathrm{N}_{2}\right.$ glove bag). We collected two grab samples, one from the head of Liberty Bay and the other near the mouth of Liberty Bay; we sent both of these to the USGS National Water Quality Lab for analysis of wastewater indicator chemicals.

1U.S. Geological Survey, Western Coastal and Marine Geology, 400 Natural Bridges Dr., Santa Cruz, CA; rtakesue@usgs.gov

2U.S. Geological Survey, Tacoma, WA 
Each week from April to May 2006, we measured in situ temperature, salinity, and dissolved oxygen from a station in Liberty Bay and a station near Point Bolin (fig. 2). We also collected discrete water samples from both stations, from $1 \mathrm{~m}$ below the surface and $1 \mathrm{~m}$ above the bottom. We immediately filtered the water samples and then froze them for dissolved inorganic nutrient analyses. To determine suspended sediment concentrations, we filtered a known volume of a second water sample through pre-weighed $0.45 \mu \mathrm{m}$ filters. In April 2006, we froze two whole water samples for nitrogen isotope and oxygen isotope analyses of nitrate.

\section{Results and Discussion}

\section{Eelgrass and Grain Size}

We observed no intertidal eelgrass beds in Liberty Bay in April 2006, consistent with a recent study by May and others (2005). The Suquamish Tribe reports no observations of intertidal or subtidal eelgrass in Liberty Bay in thirty years of monitoring (P. Dorn, personal commun.). We did, however, observe eelgrass beds around Point Bolin. Plant leaves were substantially shorter and narrower in the western eelgrass bed compared to the eastern bed (fig. 3). The western bed contained a mix of two species, Zostera marina and Z. japonica, an invasive species which colonizes higher elevations on the beach than $Z$. marina. The occurrence of $Z$. japonica in Puget Sound has been previously documented by the Washington State Department of Natural Resources. Although sediments on the west side of Point Bolin had a higher percentage of fine sediments (fig. 3), overall sediment texture was not very different at the two sites. The western eelgrass bed has a depth range from -1 to $-2 \mathrm{ft}$ (mean lower low water, MLLW), while the eastern bed ranges from +0 to at least $-5 \mathrm{ft}$ (MLLW).

The water column was more turbid on the west side of Point Bolin than on the east side, in part due to fine sediment resuspension from boat wakes. The increased turbidity could be limiting both the depth range and plant size of western eelgrass beds by creating a sub-optimal light environment. We will test his hypothesis in the 2007 field season, along with the possibility that genetic differences between plants in the two beds may be determining plant characteristics (Bachman, 1991).

Within Liberty Bay, bottom sediments were significantly coarser and more consolidated along developed (armored) sections of shore near the city of Poulsbo than along the less developed western shore (fig. 4). Sediment grain size near Poulsbo was very similar to that on the east side of Point Bolin, where the physical environment was very energetic.

Because sediments in the deepest part of Liberty Bay (20 ft water depth) were more than 90 percent mud and were dark and reducing beneath a $2 \mathrm{~mm}$-thick oxidized surface layer, fine sediments and organic matter may be accumulating in the center of Liberty Bay. It may be possible to recover long sediment cores that span the historical record from this site. The other sites that were characterized by sediments with more than 50 percent mud were near inflows of small creeks. 


\section{Wastewater Indicators}

Contrary to expectations, water column nutrient concentrations generally were lower in Liberty Bay than at Point Bolin (figs. 5 and 6). This pattern could reflect greater nutrient consumption by phytoplankton in Liberty Bay. Low silicate concentrations on May 10 were suggestive of a diatom bloom. Nitrogen and oxygen isotope ratios of nitrate will be analyzed in water samples to identify wastewater nitrogen, which is enriched in ${ }^{15} \mathrm{~N}$ and depleted in ${ }^{18} \mathrm{O}$ relative to other sources.

If wastewater nutrient loading (anthropogenic eutrophication) occurred in Liberty Bay, it did not lead to hypoxic (low oxygen) conditions (fig. 7). Water column dissolved oxygen remained high in Liberty Bay throughout April and May. Dissolved oxygen was lowest in nearbottom water at Point Bolin during a diatom bloom in Liberty Bay. This was a surprising result, because water at Point Bolin is open to exchange with water in Port Orchard.

We detected 22 wastewater indicator chemicals near the mouth of Dogfish Creek and 16 wastewater indicator chemicals near the mouth of Liberty Bay (table 1). The Dogfish CreekPoulsbo site is "clearly impacted' by wastewater, while the Liberty Bay site is "likely impacted" by wastewater (the National Water Quality Lab criteria is ten detections for impacted systems). The higher number of detections near Dogfish Creek-Poulsbo suggests that wastewater contaminants originated from the local watershed or local sewage spills, rather than from nonlocal sources. The classes of compounds detected included industrial chemicals, PAHs, fecal indicators, fragrances, and a pesticide ingredient. Total sedimentary PAH concentrations (TPAH) were far below levels of concern in Washington State; however, spatial patterns were significant. TPAH concentrations were $248 \mathrm{ng} / \mathrm{g}$ near Poulsbo and $205 \mathrm{ng} / \mathrm{g}$ in the center of Liberty Bay, relative to $33 \mathrm{ng} / \mathrm{g}$ near Point Bolin (data from R. Rosenbauer, USGS, unpublished). The relatively high TPAH concentration in the center of Liberty Bay suggests that these compounds were associated with fine sediments and/or organic matter; sediments at this site may contain historical records of PAH concentrations.

Downcore profiles of heavy metals associated with urban development (chromium, copper and lead) were much higher near the city of Poulsbo relative to Point Bolin (fig. 8). Arsenic, cadmium and zinc concentrations were similar at the two sites (not shown). Chromium was the only metal that exceeded Washington State Sediment Quality Standards (WA-SQS). Legacy chromium contamination originated from plating activities and improper disposal at the Naval Undersea Warfare Center in Keyport, at the mouth of Liberty Bay. Copper may be derived from car brake pads, anti-fouling paints, and water pipes. Lead is a legacy contaminant in Puget Sound sediments and may have been derived from leaded gasoline, leaded paint, or atmospheric emission from smelters.

\section{Conclusions}

Neither water column nutrients nor dissolved oxygen concentrations during April and May 2006 suggested anthropogenic eutrophication (nutrient loading) or hypoxic conditions resulting from wastewater inputs to Liberty Bay. However, wastewater contaminants and heavy metals in sediments showed that urban development clearly affected the nearshore region near the town of Poulsbo. Nearshore sediment grain size, nutrients, and dissolved oxygen in Liberty Bay were not unfavorable for eelgrass growth, so the absence of eelgrass in Liberty Bay remains a puzzle. It is possible that factors that were not measured, such as the width of or turbidity over the low tide terrace, contributed to the absence of eelgrass habitat in Liberty Bay. 


\section{References Cited}

Bachman, T.W., 1991, Genotypic and phenotypic variability of Zostera marina on the west coast of North America: Canadian Journal of Botany, v. 69, p. 1361-1371.

May, C.W., Barrantes, K.B., and Barrantes, L.E., 2005, Liberty Bay Nearshore Habitat Evaluation \& Enhancement Project Final Report: Published by the Lemolo Citizens Club and Liberty Bay Foundation, USEPA Non-Point Source Pollution Funds Grant Project \#G0100125.

Terrados, J., and others, 1999, Are seagrass growth and survival constrained by the reducing conditions of the sediment? Aquatic Botany, v. 65, p. 175-197.

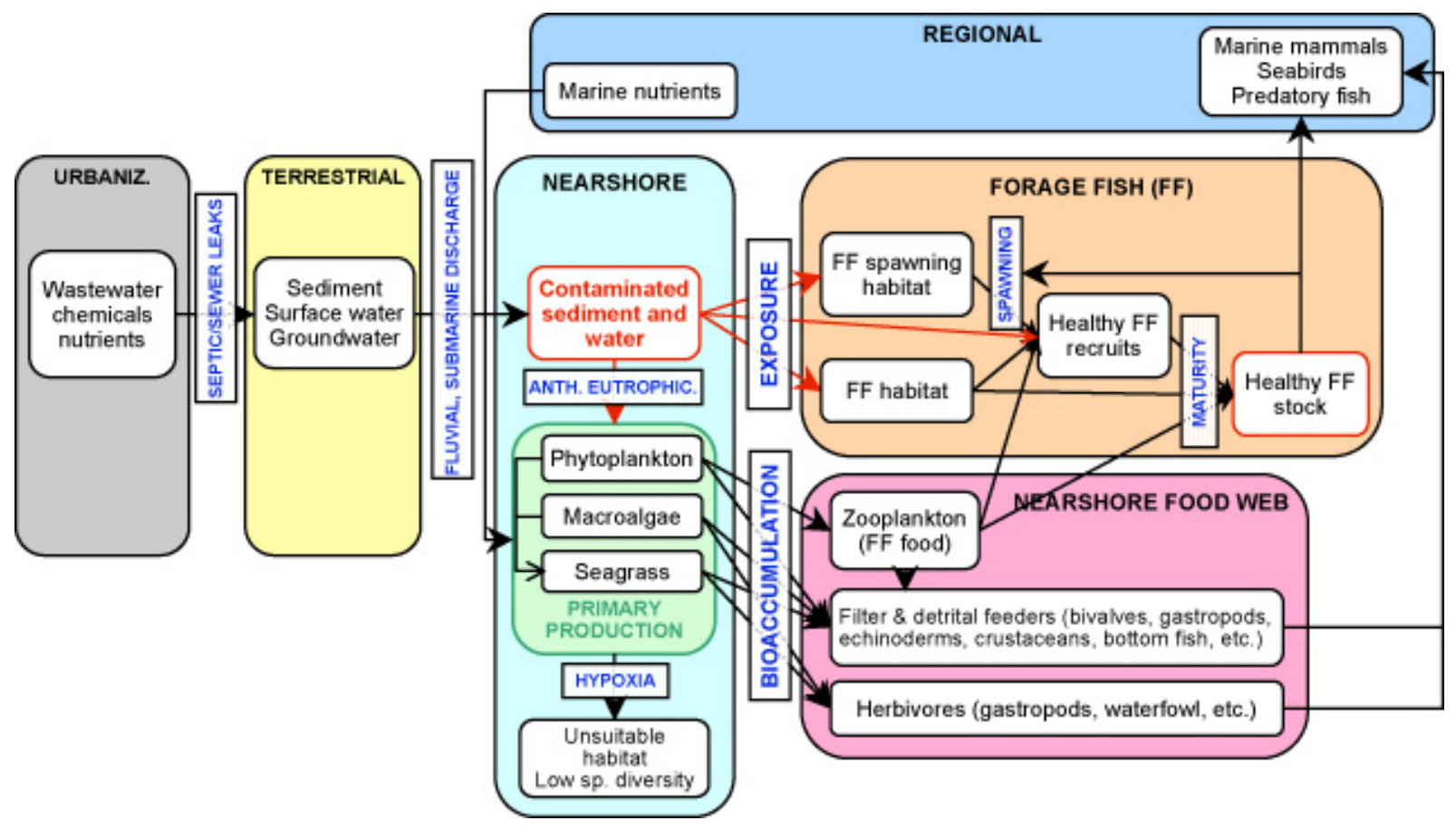

Figure 1. Conceptual model of wastewater impacts on nearshore water quality, sediment quality, primary productivity, and food webs. 


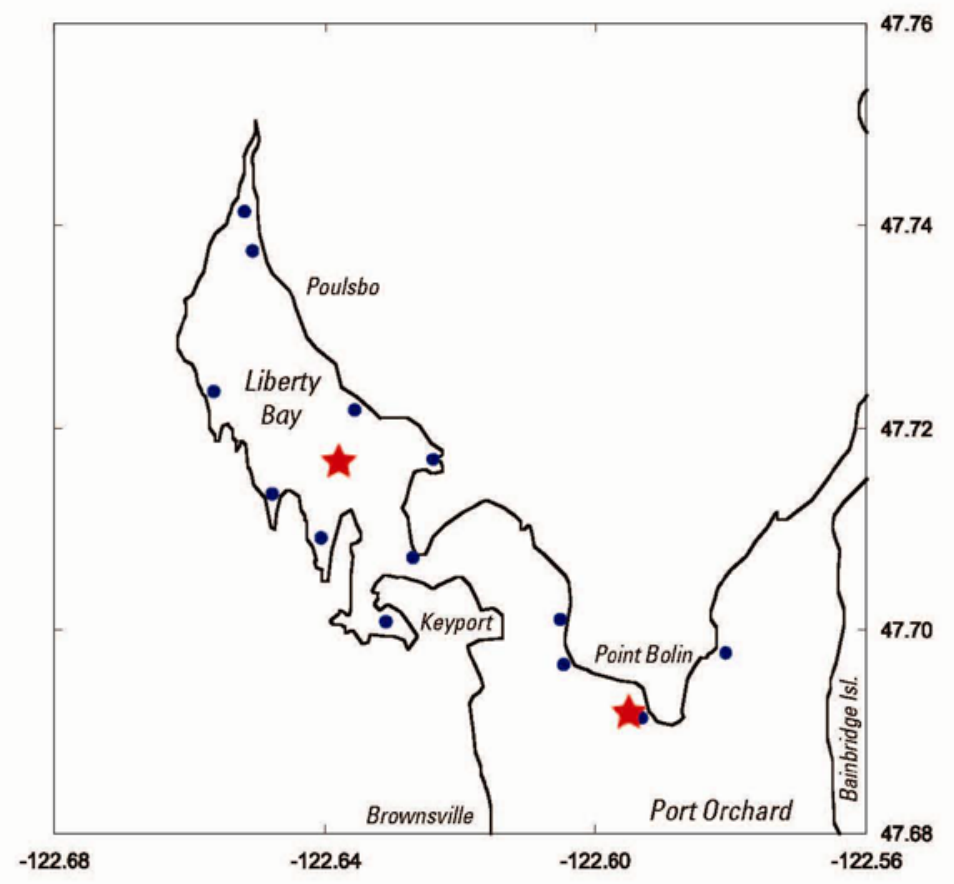

Figure 2. Map showing locations where surface sediments were sampled (blue dots) and water column properties were measured (red stars). 


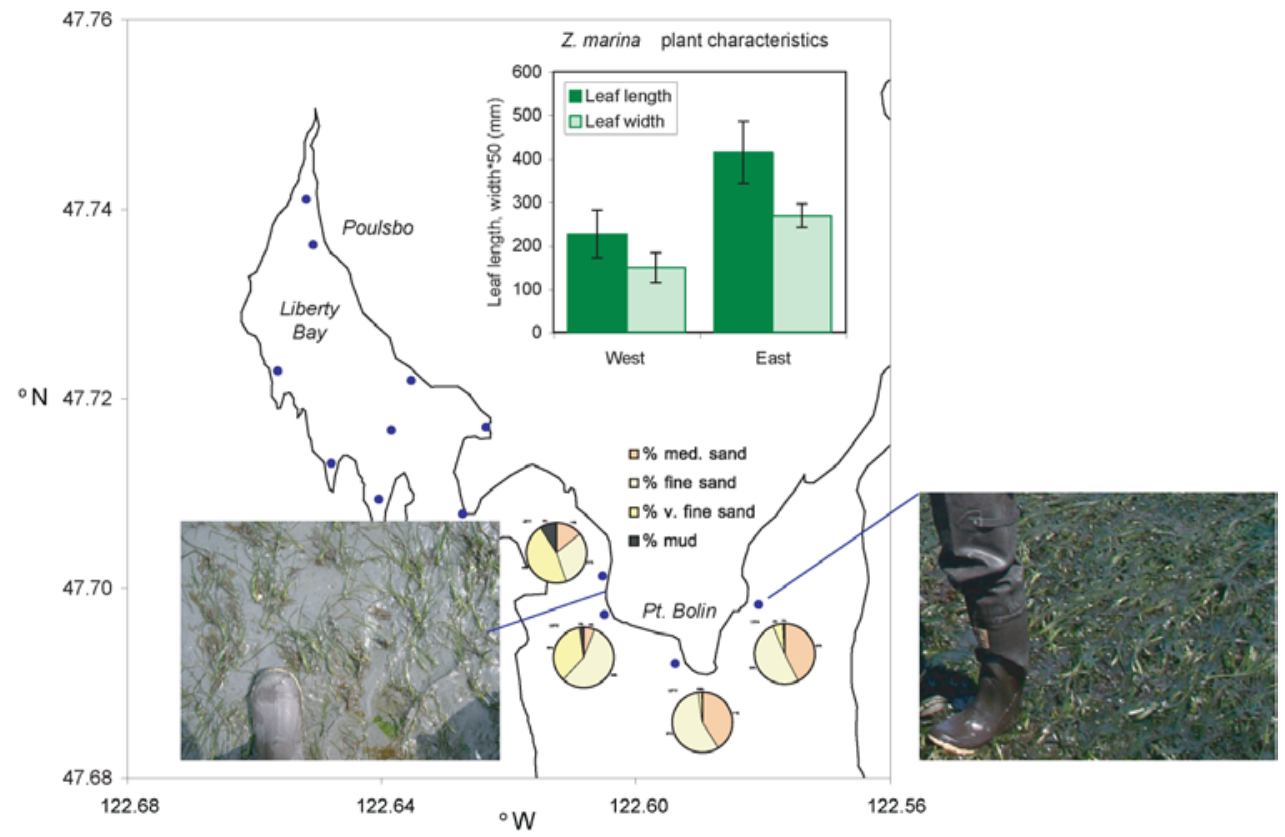

Figure 3. Eelgrass leaves from beds on the west side of Point Bolin were significantly shorter and narrower than those from beds on the east side. Bar graph shows leaf lengths and widths in the two beds, error bars show $\pm 1 \sigma$. Sediment grain size distributions are shown as pie charts (percent weight). 


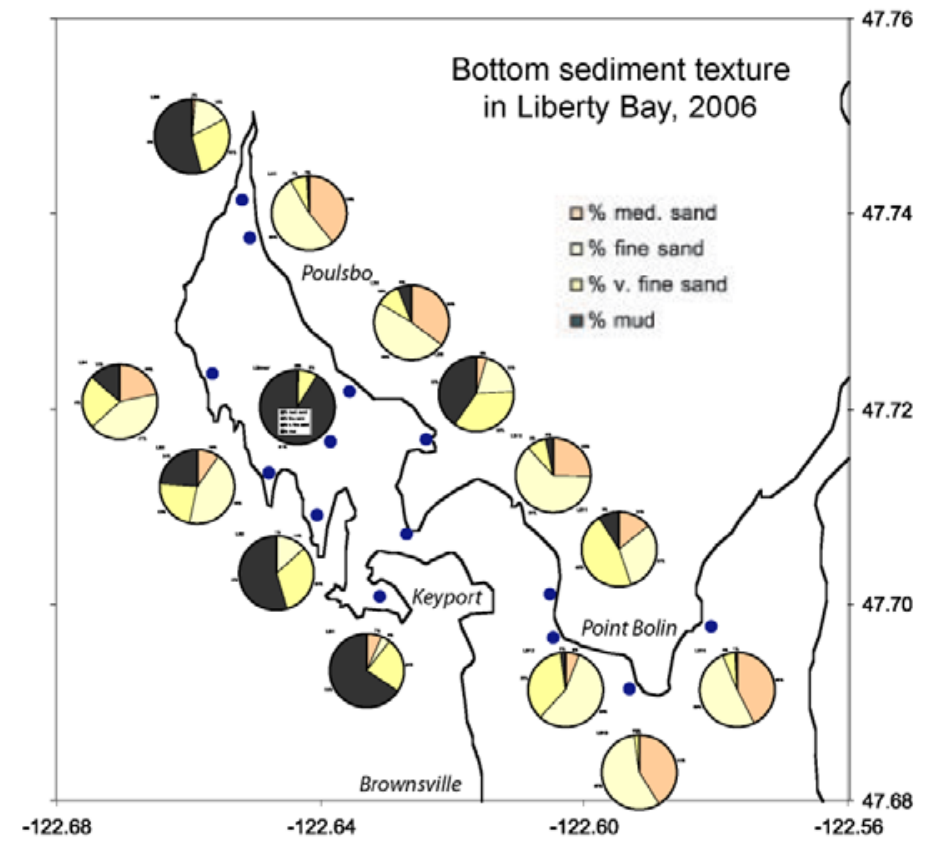

Figure 4. Bottom sediment texture in Liberty Bay and around Point Bolin in April 2006. The distance from Poulsbo to Point Bolin is about $6.5 \mathrm{~km}$.

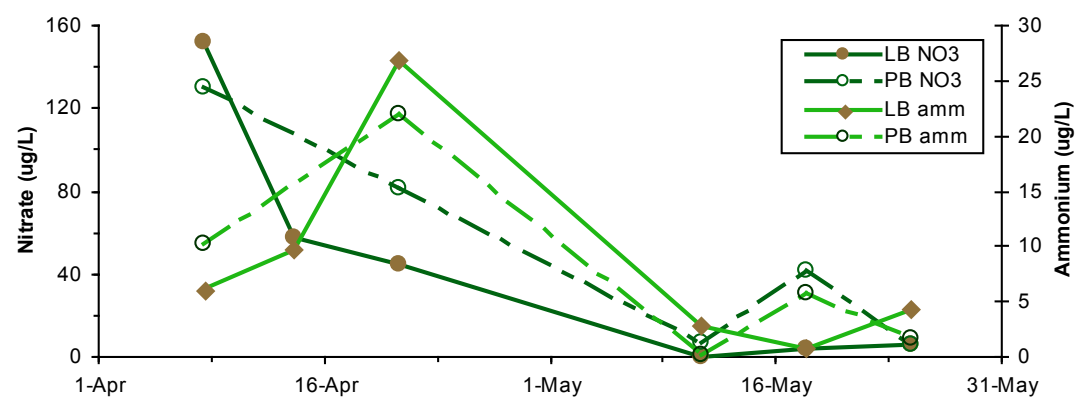

Figure 5. Dissolved inorganic nitrate $\left(\mathrm{NO}_{3}\right.$, nitrate+nitrite) and ammonium $(\mathrm{amm})$ concentrations in surface waters of Liberty Bay (LB) and Point Bolin (PB) during April and May 2006. 


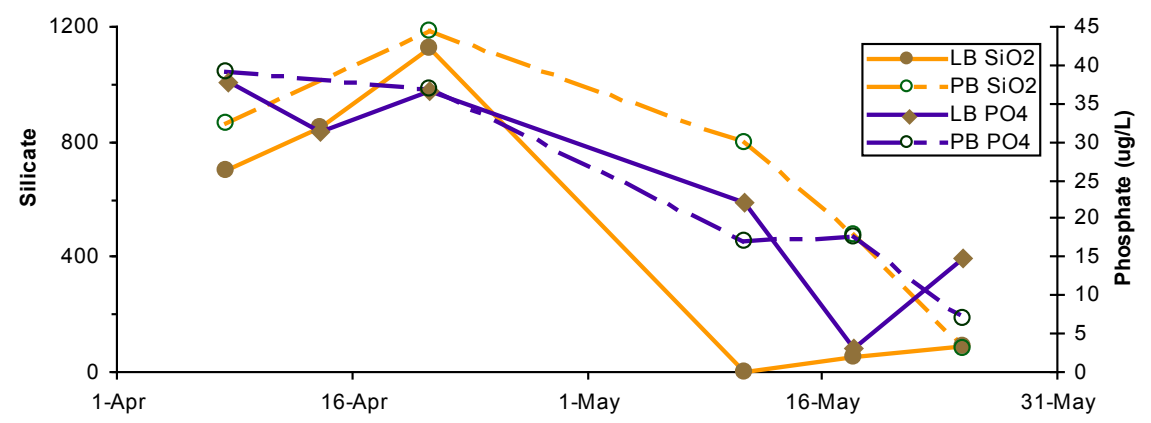

Figure 6. Dissolved inorganic silicate $\left(\mathrm{SiO}_{2}\right)$ and phosphate $\left(\mathrm{PO}_{4}\right)$ in surface waters of Liberty Bay $(\mathrm{LB})$ and Point Bolin (PB) during April and May 2006.

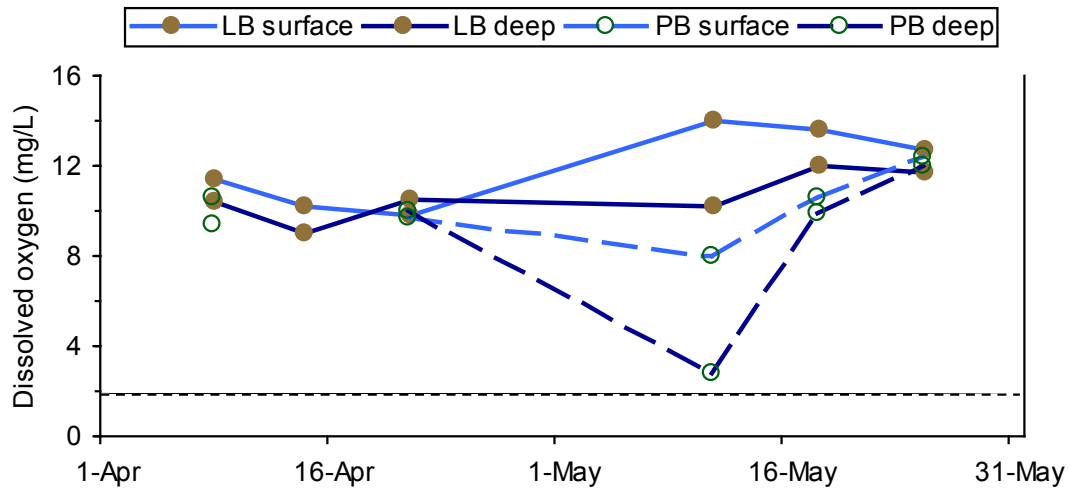

Figure 7. Dissolved oxygen in surface and bottom waters of Liberty Bay (LB) and Point Bolin (PB) during April and May 2006. Dashed line shows the level at which waters become hypoxic. 


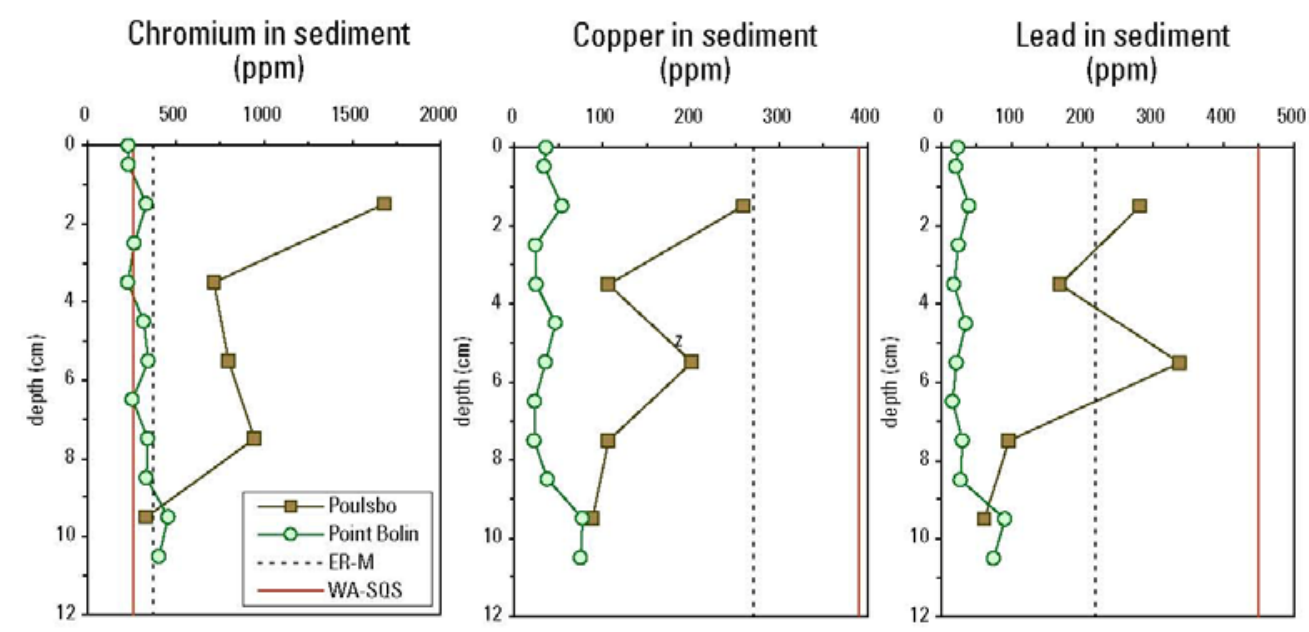

Figure 8. Downcore profiles of chromium, copper and lead near Poulsbo and Point Bolin. Red lines show Washington State Sediment Quality Standard (SQS) levels. Dashed lines show National Oceanographic and Atmospheric Administration Effects Range-Median (ER-M) levels, above which adverse biological affects frequently occur.

Table 1. Numbers of detections of wastewater indicator chemicals summarized by compound classes in sediments collected near Poulsbo and near the mouth of Liberty Bay.

\begin{tabular}{lll}
\hline \multicolumn{1}{c}{ Compound classes ${ }^{1}$} & Poulsbo $^{1}$ & Liberty Bay mouth $^{1}$ \\
\hline PAHs & 7 & 7 \\
Industrial compounds & 4 & 3 \\
Plant/animal sterol (fecal indicators) & 4 & 3 \\
Detergents and their metabolites & 3 & n.d. \\
Flavors and fragrances & 3 & 2 \\
Pesticides & 1 & 1 \\
Prescription pharmaceutical & n.d. & n.d. \\
Non-prescription pharmaceutical & n.d. & n.d. \\
Flame retardants & n.d. & n.d. \\
Household wastewater & n.d. & n.d. \\
Total detections & & 16 \\
\hline
\end{tabular}

${ }^{1}$ n.d. $=$ not detected 


\title{
Tracking Wastewater Inputs and Trophic Dynamics with Stable Isotopes in Liberty Bay, Washington
}

\author{
By Theresa L. Liedtke ${ }^{1}$ and Dennis W. Rondorf 2
}

\begin{abstract}
The potential for wastewater leakage into Liberty Bay is high because the majority of dwellings within the watershed use on-site septic systems. Local media report that septic tank leaks are a problem in Liberty Bay, as are sewage spills from an ageing pipeline. Sewage inputs, whether from septic systems or pipeline breaks, could impact food web dynamics. If wastewater nitrogen inputs increase primary productivity in Liberty Bay, then stable nitrogen isotope ratios $\left(\delta^{15} \mathrm{~N}\right)$ of organisms using these nutrients should be distinct from those of organisms using marine nitrogen sources, because the $\delta^{15} \mathrm{~N}$ value of wastewater nitrogen is several per mil higher than marine nitrogen, and because organisms become progressively enriched in ${ }^{15} \mathrm{~N}$ with increasing trophic level. We investigated trophic dynamics in Liberty Bay and at a non-impacted reference site (Point Bolin) using stable nitrogen isotope ratios in plants, animals, and sediments. We hypothesized that the samples from Liberty Bay would have $\delta^{15} \mathrm{~N}$ signatures more similar to wastewater than the samples from Point Bolin. Working with the Suquamish Tribe and the Liberty Bay Foundation, we collected 140 biological tissue samples for $\delta^{15} \mathrm{~N}$ analyses during four field efforts. Although samples at some trophic levels were quite variable, the $\delta^{15} \mathrm{~N}$ of samples from Liberty Bay were generally higher than those from Point Bolin, suggesting that wastewater ${ }^{15} \mathrm{~N}$ was used by organisms in Liberty Bay.
\end{abstract}

Key Words: wastewater, trophic, isotopes, food web

\footnotetext{
${ }^{1}$ U.S. Geological Survey, Columbia River Research Laboratory, 5501A Cook-Underwood Road, Cook, WA 98605; theresa_liedtke@usgs.gov

${ }^{2}$ U.S. Geological Survey, Columbia River Research Laboratory, 5501A Cook-Underwood Road, Cook, WA 98605; drondorf@usgs.gov
} 


\title{
Coastal Habitats in Puget Sound (CHIPS) Urbanization Task FY07 Research Plans
}

\author{
By Renee Takesue ${ }^{1}$, Jessie Lacy², Rick Dinicola ${ }^{3}$, Ray Watts ${ }^{4}$, Vivian Queija ${ }^{5}$, Dennis Rondorf6, Theresa \\ Liedtke $^{6}$, and Paul Hershberger ${ }^{7}$
}

\begin{abstract}
In the upcoming year, the CHIPS Urbanization team will investigate impacts of shoreline armoring on beach-spawning forage fish. We will also follow up on some interesting questions that arose from the pilot study and will continue investigating wastewater contaminants in Liberty Bay.
\end{abstract}

Key Words: Urbanization, shoreline armoring, forage fish, groundwater

\section{Effects of Shoreline Armoring on Beach-Spawning Forage Fish}

Two species of forage fish, surf smelt (Hypomesus pretiosus) and sand lance (Ammodytes hexapterus), spawn in winter near the high tide line on sand and gravel beaches. Conceptually, shoreline armoring may eliminate spawning habitat if the beach in the upper intertidal zone is covered or eroded, or if upper beach grain size coarsens beyond an acceptable range (fig. 1). The removal of vegetation overhanging the upper beach may contribute to desiccation of forage fish eggs. Our field efforts will occur in and around Liberty Bay and will include forage fish egg surveys and winter and spring beach elevation and grain size surveys. We will describe characteristics of bulkheads at the surveyed beaches. Statistical correlations will be used to show linkages between bulkhead or beach characteristics and spawning occurrence or spawning intensity.

\section{Impact of Boat Wake-Induced Turbidity on Eelgrass}

During the pilot study, we observed that boat wakes impinge on the low tide terrace and resuspend fine sediments over eelgrass beds. In spring 2007, we will explore whether boat wakeinduced turbidity limits light for eelgrass growth. We will deploy turbidity and pressure sensors (Self-logging Optical Backscatter sensors, SLOBs) over eelgrass beds containing small plants outside of the mouth of Liberty Bay. The eelgrass bed at Sandy Hook on Agate Pass will serve as a reference site. We will document eelgrass plant and bed characteristics at the end of the SLOB

\footnotetext{
${ }^{1}$ U.S. Geological Survey, Coastal \& Marine Geology, 400 Natural Bridges Dr., Santa Cruz, CA; rtakesue@usgs.gov

${ }^{2}$ U.S. Geological Survey, Santa Cruz, CA

${ }^{3}$ U.S. Geological Survey, 934 Broadway, Suite 300, Tacoma, WA 98402

${ }^{4}$ U.S. Geological Survey, Fort Collins, CO

${ }^{5}$ U.S. Geological Survey, Seattle, WA 98104

${ }^{6}$ U.S. Geological Survey, Cook, WA

${ }^{7}$ U.S. Geological Survey, Nordland, WA
} 
deployment, and we will document the number and duration of boat wakes when the water level is up to one foot higher than the eelgrass bed. Observed boat wakes will be compared to the SLOB turbidity and pressure time series to help distinguish wake-induced turbidity events from turbidity induced by other processes such as wind or waves. Turbidity levels over eelgrass beds will be compared to known tolerance ranges.

\section{Wastewater Chemicals in Groundwater and the Sedimentary Record}

We will collaborate with Peter Swarzenski (U.S. Geological Survey, Santa Cruz, CA) to locate and quantify submarine groundwater discharge in Liberty Bay and around Point Bolin, using stationary or streaming resistivity measurements. Jennifer Dougherty, a Stanford University graduate student, will measure groundwater and sediment concentrations of chemicals in the class of wastewater contaminants known as personal care and pharmaceutical products (PPCPs). PPCPs enter groundwater from leaking and properly functioning septic systems. We will conduct boat-mounted acoustic Doppler Current Profiler (ADCP) surveys to investigate how wastewater contaminants may be transported in Liberty Bay. In collaboration with Skagit Bay work, we will recover long sediment cores to reconstruct past sedimentation rates and urban contaminant loading in Liberty Bay. Historical analysis of land use around Liberty Bay and its watersheds may contribute to an understanding of how urban development affects sediment budget and contaminant loading.

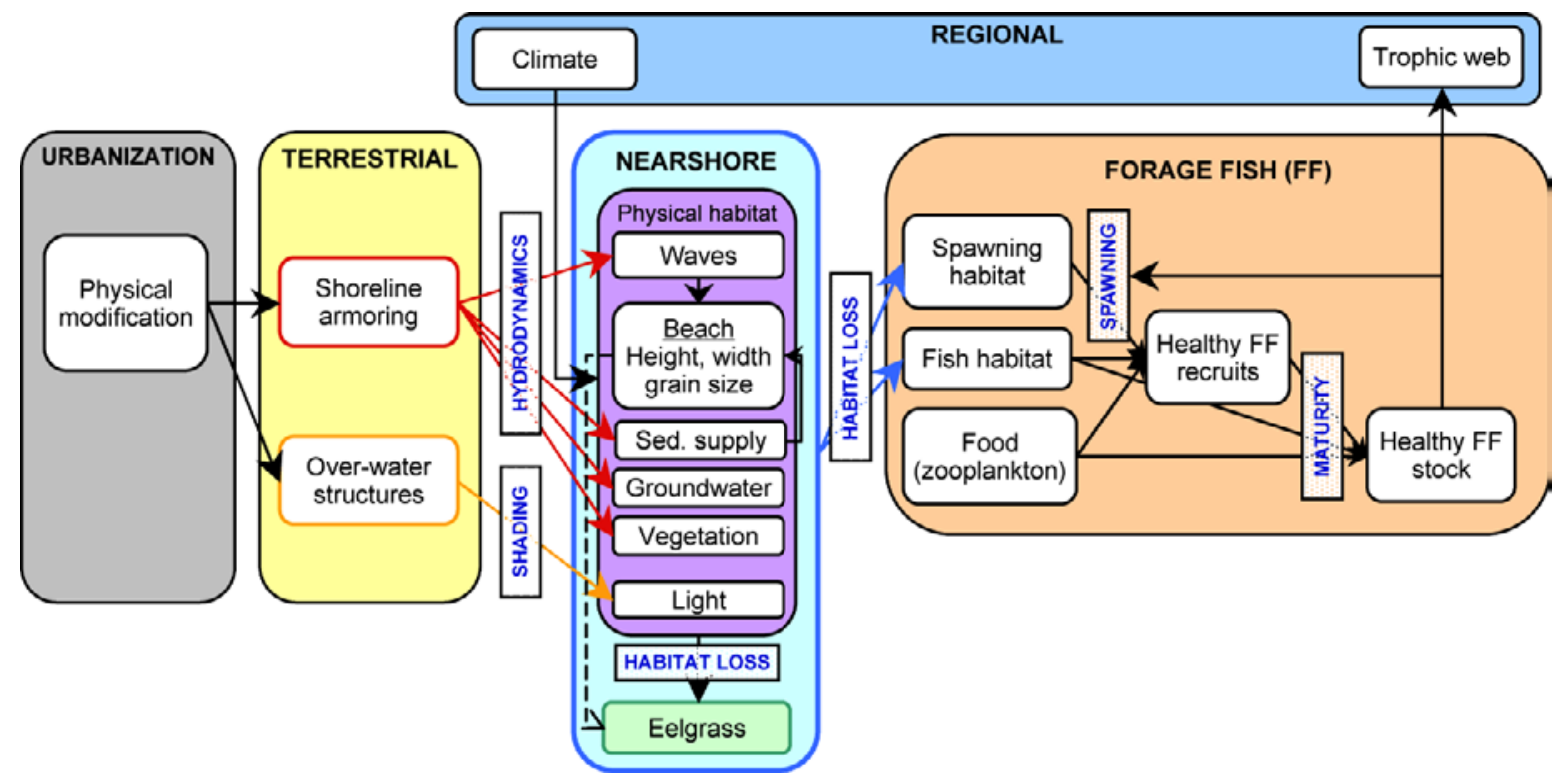

Figure 1. Conceptual model showing the processes by which physical modification of the shoreline, including shoreline armoring, affect nearshore habitat characteristics and beach-spawning forage fish. 


\title{
Nearshore Sediment Dynamics at Possession Point, Whidbey Island, Washington
}

By Jessie Lacy1

\begin{abstract}
In 2007, we will begin a field investigation of beach dynamics, sediment transport, the interaction of eelgrass (Zostera marina) with waves and tidal currents, and physical and geochemical factors influencing eelgrass distribution at Possession Point, Whidbey Island (fig. 1), as part of the Beach and Nearshore Sediment Dynamics Task of Coastal and Marine Geology's Coastal Habitats in Puget Sound (CHIPS) Project. First year data collected will provide baseline information for investigation of the influence of shoreline armoring in collaboration with the Multi-Disciplinary CHIPS (MD-CHIPS) Effects of Urbanization Task in future years. Possession Point exhibits a strong gradient in wave exposure (from an erosive point to a more sheltered cove), appears to have significant longshore sand transport (evidenced by extensive sand bars), has healthy fringing eelgrass meadows along portions of the coast and no eelgrass along other portions, and has good public access.
\end{abstract}

Key Words: Sediment transport, beach dynamics, eelgrass distribution.

\section{Initial Study Plan}

We will map bathymetry and eelgrass distribution along about $5 \mathrm{~km}$ of the low tide terrace at Possession Point; we will also measure grain size and geochemical properties of sediment, with the goal of correlating them to eelgrass distribution and density. We will monitor nearshore morphology in spring and fall to link shoreline change with sediment transport measurements. We have completed the first fall survey (September 2006).

We plan to deploy oceanographic instrumentation to capture winter wave events. This deployment will allow us (1) to measure tidal currents and quantify the gradient in wave energy from Possession Point north; (2) to investigate the relative importance of waves and tidal currents to sediment resuspension and transport on the low tide terrace; (3) to investigate the influence of fringing eelgrass meadows on sediment resuspension and transport on the low tide terrace; and (4) to document the response of eelgrass to waves with video, and investigate whether fringing meadows reduce near-bed wave velocities.

\footnotetext{
${ }^{1}$ U.S. Geological Survey, Western Coastal \& Marine Geology, 400 Natural Bridges Dr., Santa Cruz, CA; jlacy@usgs.gov
} 


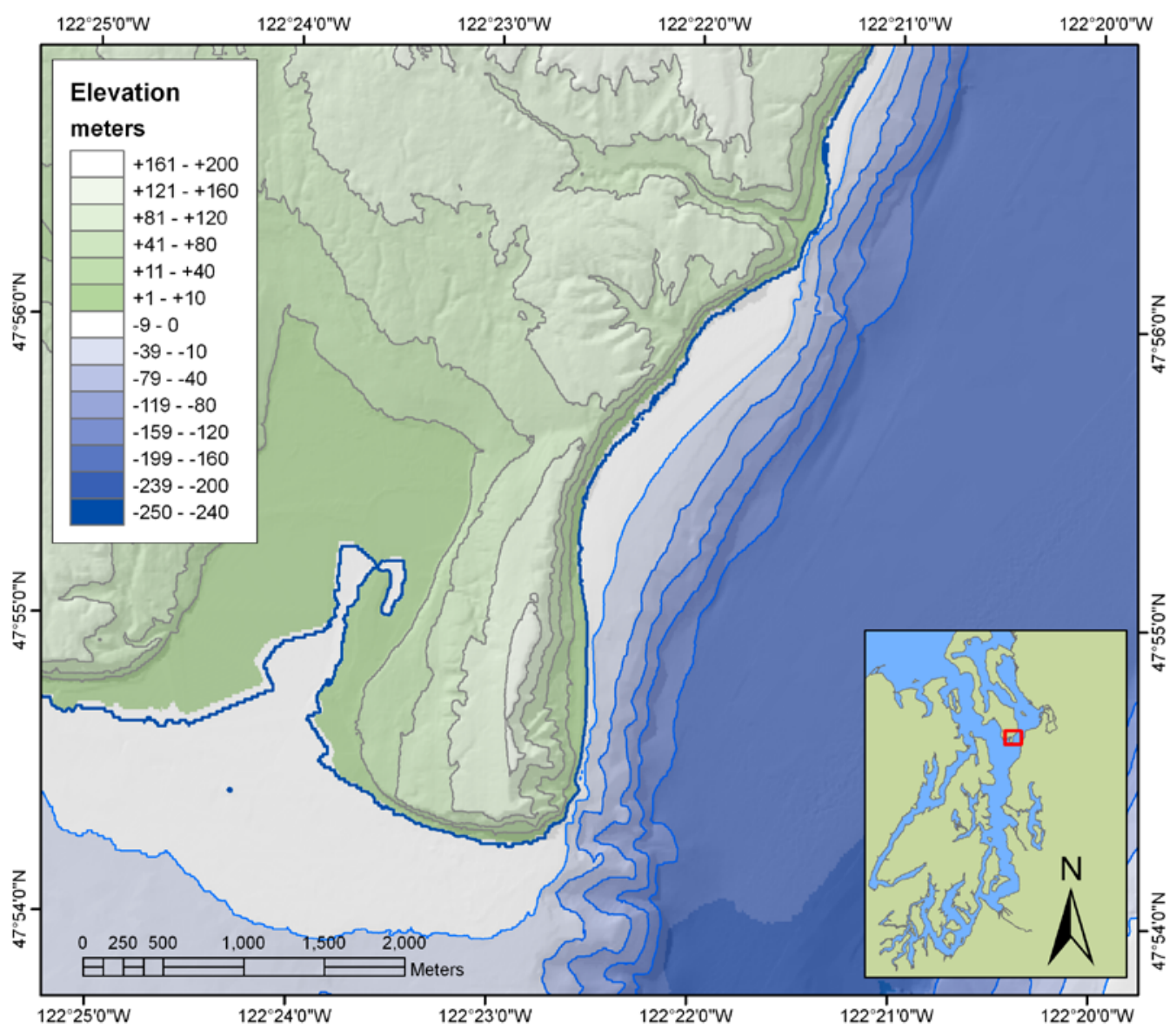

Figure 1. Study area at Possession Point, Whidbey Island. 


\title{
Marine Fish Health Research at the Marrowstone Marine Field Station, Nordland, Washington
}

\author{
By Paul Hershberger ${ }^{1}$
}

\begin{abstract}
Impacts of infectious and parasitic diseases to populations of wild, marine and anadromous fishes are poorly understood, primarily because the gross predominance of fish health research has historically focused on cultured fishes. Further, most accounts of disease processes in populations of wild marine fishes are limited to descriptions of ensuing epizootics. Unfortunately, only limited information about causes of the epidemics can be obtained by investigating disease outbreaks after they occur. Research at the Marrowstone Marine Station is directed towards understanding natural disease processes and environmental variables that influence disease kinetics. Our approach employs a combination of field surveys and empirical laboratory studies intended to provide predictive metrics useful in forecasting epizootics. Once this predictive capability is developed, management strategies, intended to mitigate the detrimental effects of disease to populations of marine fishes, can be employed. Our research studies three disease conditions (viral hemorrhagic septicemia, viral erythrocytic necrosis, and ichthyophoniasis) that have been associated with epizootics in Pacific herring (Clupea harengus pallasi).
\end{abstract}

Key Words: Pacific herring, disease, parasites

\footnotetext{
${ }^{1}$ U.S. Geological Survey, Western Fisheries Research Center, Marrowstone Marine Field Station 616 Marrowstone Point Road, Nordland, WA 98358; phershberger@usgs.gov
} 


\title{
Dissolved Inorganic Loads to Lynch Cove, Hood Canal, Washington
}

\author{
By Anthony J. Paulson'1, Chris Konrad², Lonna Frans², Reagan Huffman², Theresa Olsen², and Marlene
} Noble $^{3}$

\begin{abstract}
In September and October 2004, we collected field data to estimate dissolved inorganic nitrogen (DIN) loads to Lynch Cove, the most inland marine waters of Hood Canal, WA, that routinely contain low dissolved-oxygen bottom waters. Based on measured values of stream flow and DIN concentrations, we estimated that surface discharge contributed about one-fourth of the load of DIN to the upper layer of Lynch Cove. Groundwater flow from watersheds contributed about one-half of the total DIN load to the upper layer. Marine currents appear to have carried more than 25 times the total input of DIN to the upper layer from surface and groundwater, nearshore septic systems, and direct atmospheric rainfall. The subsurface maximums in measured backscatter, chlorophyll $a$, particulate organic carbon, and particulate organic nitrogen strongly suggest that upward mixing of nitrate-rich deeper water controls the supply of DIN to the upper layer, which enhances marine productivity in Lynch Cove. Reversals in the normal estuarine circulation suggest that if the relative importance of the DIN load between terrestrial and marine sources in controlling dissolved oxygen concentrations in Lynch Cove is to be better understood, then the physical forces driving Hood Canal circulation must be better defined.
\end{abstract}

Key Words: Hood Canal, nitrogen, low dissolved oxygen, circulation

1U.S. Geological Survey, Washington Water Science Center, 934 Broadway, Suite 300, Tacoma, WA; apaulson@usgs.gov

2U.S. Geological Survey, Tacoma, WA

3U.S. Geological Survey, Menlo Park, CA 


\title{
A Geochemical and Geophysical Examination of Submarine Groundwater Discharge and Associated Nutrient Loading Estimates into Lynch Cove, Hood Canal, Washington
}

\author{
By Peter Swarzenski1 , F.W. Simonds², Chris Reich ${ }^{3}$, Don Rosenberry4, and Rick Dinicola²
}

\begin{abstract}
Coastal scientists have cast submarine groundwater discharge (SGD) into a global spotlight by describing the ubiquitous nature of SGD along varied coastlines and by identifying and quantifying the importance of SGD to coastal material and water budgets. Research has shown that the discharge of nutrient-enriched groundwater into coastal waters can cause nutrient enrichments that can lead to phytoplankton blooms and eutrophication. Discharge of coastal groundwater most often is diffuse, rather than through distinct, submarine vent features, making assessment of SGD rates difficult. New geochemical tracer techniques and novel direct-current (DC) geophysical methods have consequently been developed to address SGD rates, forcing factors and scales.

We present geochemical tracer data, electromagnetic (EM) seepage meter results, and streaming and stationary DC resistivity profiles to identify potential hotspots of SGD into Lynch Cove, the terminus of the Hood Canal, WA fjord. Time series of stationary DC resistivity profiles at Sunset Beach clearly show tidally forced subsurface salinity intrusions to depth in excess of $20 \mathrm{~m}$. Near continuous radon measurements (222Rn is a noble gas with a half-life of 3.8 days) in the near-shore surface waters of Lynch Cove were slightly elevated in the midsection of Lynch Cove, where steeper hydraulic gradients on shore could force increased SGD. A 5 -day ${ }^{222} \mathrm{Rn}$ time series at the Merrimont site (fig. 1) shows a strong inverse covariance between ${ }^{222} \mathrm{Rn}$ and the tidal stage (water level); this time series provides compelling evidence for enhanced, tidally-modulated SGD. Such Rn-derived SGD rates average about $85 \pm 84 \mathrm{~cm} \mathrm{~d}^{-1}, \mathrm{n}=$ 501. A similar time-series deployment of an EM seepage meter at Merrimont also showed a strong water-level control on advective exchange rates that peaked (up to $80 \mathrm{~cm} \mathrm{~d}^{-1}$ ) during the low tide events and also showed extended periods of submarine groundwater recharge during high tide events.
\end{abstract}

1U.S. Geological Survey, 400 Natural Bridges Dr. Santa Cruz, CA 95065; pswarzen@usgs.gov

2U.S. Geological Survey, 934 Broadway, Suite 300, Tacoma, WA 98402

3 U.S. Geological Survey, $6004^{\text {th }}$ Street S., St Petersburg, FL 33701

4U.S. Geological Survey, P.O. Box 25046, MS 413 Denver, CO 80225 
One can estimate SGD-derived nutrient loading estimates into Lynch Cove by simply multiplying the mean groundwater nutrient concentrations by the SGD rate normalized to a specific area of discharge. Assuming an advective Rn-derived SGD rate of $85 \mathrm{~cm} \mathrm{~d}^{-1}$ results in submarine groundwater loading estimates of $1.3 \times 10^{4} \mathrm{~mol} \mathrm{~d}^{-1}$ for dissolved organic nitrogen (DON), $5.9 \times 10^{4} \mathrm{~mol} \mathrm{~d}^{-1}$ for dissolved inorganic nitrogen (DIN), $2.6 \times 10^{3} \mathrm{~mol} \mathrm{~d}^{-1}$ for phosphate $\left(\mathrm{PO}_{4}^{3-}\right.$ ), and $3.6 \times 10^{5} \mathrm{~mol} \mathrm{~d}^{-1}$ for silicate ( $\mathrm{Si}$ ). The mean Rn-derived advective rate of $85 \mathrm{~cm} \mathrm{~d}^{-1}$, multiplied by the representative SGD area, would correspond to a regional SGD rate of $28.4 \mathrm{~m}^{3}$ $\mathrm{s}^{-1}$, a value up to eight times higher than previous estimates.

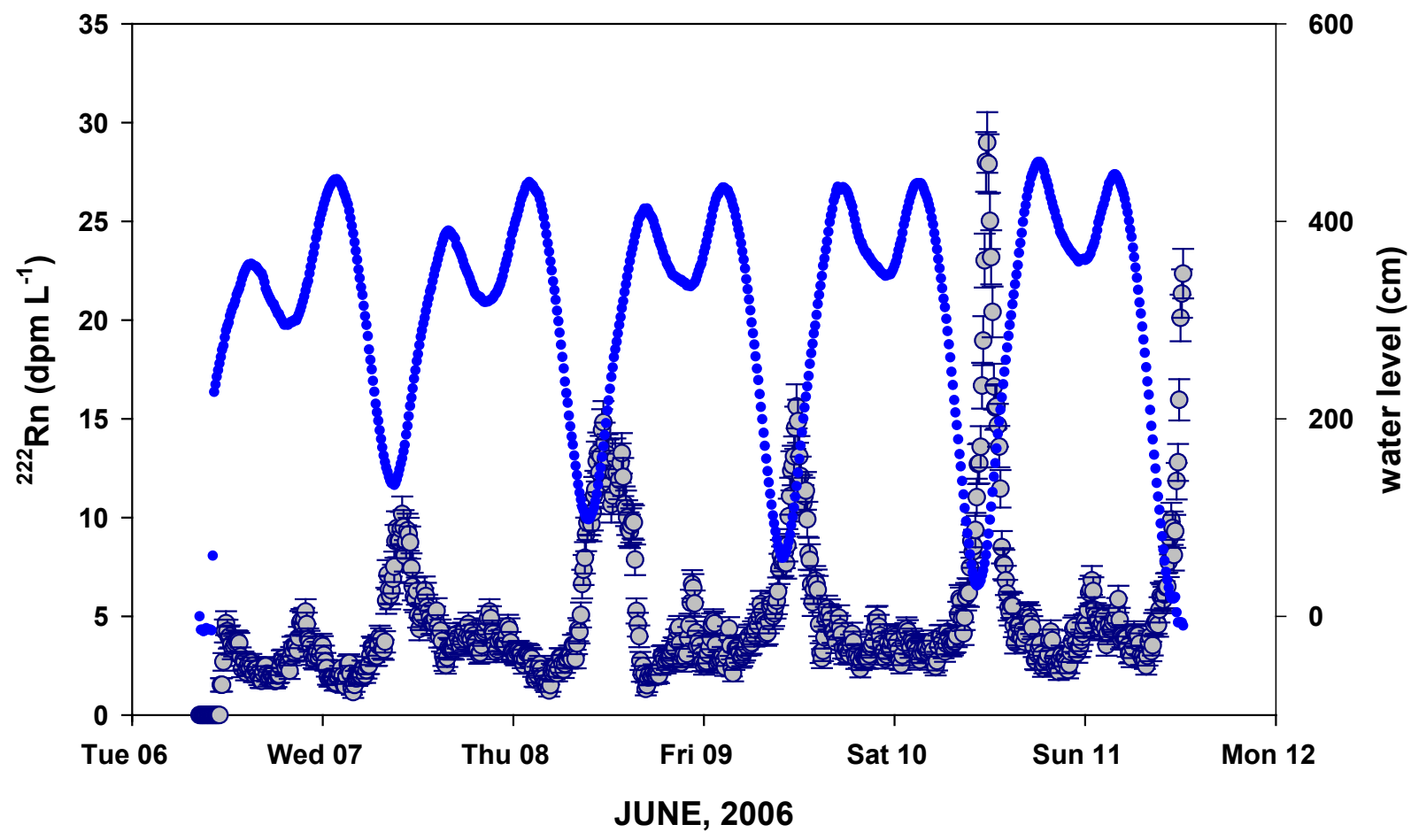

Figure 1. Five-day, bottom water ${ }^{222}$ Rn time series at the Merrimont site, Hood Canal WA. 


\title{
Integrated Landscape Monitoring in the Puget Sound
}

\author{
By Christian Torgersen ${ }^{1}$, Guy Gelfenbaum², Liora Llewellyn³, Mark Munn ${ }^{4}$, and Vivian Queija ${ }^{5}$
}

\begin{abstract}
An interdisciplinary consortium is developing conceptual approaches for detecting, understanding, and predicting the effects of landscape change on freshwater, marine, estuarine, and terrestrial ecosystems in the Puget Sound. The implementation team lead by the U.S. Geological Survey (USGS) consists of researchers and natural resource managers at city, county, state, and federal levels in the Puget Sound. We will develop conceptual models of the effects of landscape change on Puget Sound ecosystems that describe the components of landscape change and relate these patterns to ecological function. Managers and scientists could then use these models to identify monitoring needed to measure and evaluate potential indicators of landscape conditions at scales necessary to inform management issues and practices. Over time, others could apply the findings of this pilot project and test them on other landscapes throughout the United States so that our ability to deliver integrated landscape monitoring across the North American landscape will be enhanced. By linking approaches to landscape monitoring employed by multiple land management agencies, this project aims to bridge the gap between local monitoring efforts and regional satellite-based mapping projects, thereby facilitating the detection and prediction of broad-scale human impacts on aquatic and terrestrial ecosystems.
\end{abstract}

Key Words: monitoring, remote sensing, landscape, conceptual modeling, ecological indicators

1 U.S. Geological Survey, Forest and Rangeland Ecosystem Science Center, Cascadia Field Station, University of Washington, College of Forest Resources, Box 352100, Seattle, WA 98195-2100; ctorgersen@usgs.gov

2U.S. Geological Survey, Menlo Park, CA

3University of Washington, College of Forest Resources, Seattle, WA

${ }^{4}$ U.S. Geological Survey, Tacoma, WA

${ }^{5}$ U.S. Geological Survey, Seattle, WA 


\title{
Long-Term Hydrodynamic and Morphological Modeling for the Deschutes River Estuary Feasibility Study, Washington
}

\author{
By Guy Gelfenbaum¹, Douglas A. George², Giles R. Lesser ${ }^{3}$, Andrew Stevens², and Curtis D. Tanner ${ }^{4}$
}

\begin{abstract}
Since 1951, when a tide gate was installed across the Deschutes Estuary to create Capital Lake in southern Puget Sound, Washington, the lake has been filling with sediment. Approximately 1.3 million cubic meters of mud, sand, and gravel have filled the lake since the dam was built, resulting in numerous lake management issues. One option for dealing with some of these issues is to remove the dam and restore estuarine processes. As part of the Deschutes Estuary Feasibility study, which is investigating the restoration of Capitol Lake to its historical Deschutes Estuary condition, we developed a hydrodynamic and sediment transport model to predict the flow, salinity, sediment transport, and morphological change that would occur under several restoration scenarios.

Model results provide information from restoration scenarios to the many groups involved in the project. For ecologists, the model provides salinity regimes, inundation frequencies and sediment grain size distributions to develop physical habitat maps of the estuary. They will combine this information with field observations of flora and fauna from nearby 'reference estuaries' to estimate the communities that may colonize a restored estuary. The model yields velocity fields, circulation patterns and morphological change that will be used by engineers to analyze threats to existing infrastructure around the lake. The model results will assist municipal planners form a physical description of the restored estuary, which will include exposure of mudflats and turbidity of the water. For managers of the commercial Port of Olympia, which is downstream of the restored estuary, the model allows estimation of the rate and amount of sediment deposited in the port. Approximate maintenance costs of the port and nearby municipal marina will be based on these results.
\end{abstract}

Key Words: Sediment transport model, estuary, Deschutes

1U.S. Geological Survey, Coastal and Marine Geology; 345 Middlefield Rd, MS 999, Menlo Park, CA 94025; ggelfenbaum@usgs.gov 2U.S. Geological Survey, Menlo Park, CA

${ }^{3}$ Delft Hydraulics, Menlo Park, CA

${ }^{4}$ U.S. Fish and Wildlife Service, Olympia, WA 


\section{River Methods}

Using Delft3D, a process-based morphological model, we set up both a 2D and a 3D model of the Deschutes estuary region and lower Budd Inlet. The models contained approximately 6,100 grid cells, ranging from 100 to $3500 \mathrm{~m}^{2}$ in size. The smallest grid resolution was in the vicinity of the main channel in Lower and Middle Basins. Long-term simulations were required to inform decision-makers of both the biological response and the sediment transport and erosion/accretion for the scenarios. The development of 1-yr, 3-yr, and 10-yr simulations of the restored estuary required simplifying several data inputs and implementing a time-scale acceleration technique.

We developed a river sediment discharge climatology based on the Deschutes River hydrograph and used a representative tide selected from the 4-m semi-diurnal tidal range. To reduce the computational time of the long-term simulations, we employed a variable morphological factor, which is a scaling factor that relates the hydrodynamic time scale to the morphological time scales.

\section{Results}

Long-term sediment transport simulations show that immediately after removing the tide gate estuarine processes are restored. Within one year, a channel will erode. The sediment in that channel will get coarser, and sediment along the adjacent tide flats will get finer. Some of the fine sediment that erodes from the estuary will accumulate outside of the estuary in the vicinity of the port and marina. The degree to which the channel erodes and the volume of sediment that ultimately accumulates in the port and marina depends on the erodibility of the mud in the lake region. The erodibility of lake or estuarine mud depends on several physical and biological characteristics, such as water content, compaction, mucus coatings, and others, that unfortunately, were not measured in the field. 

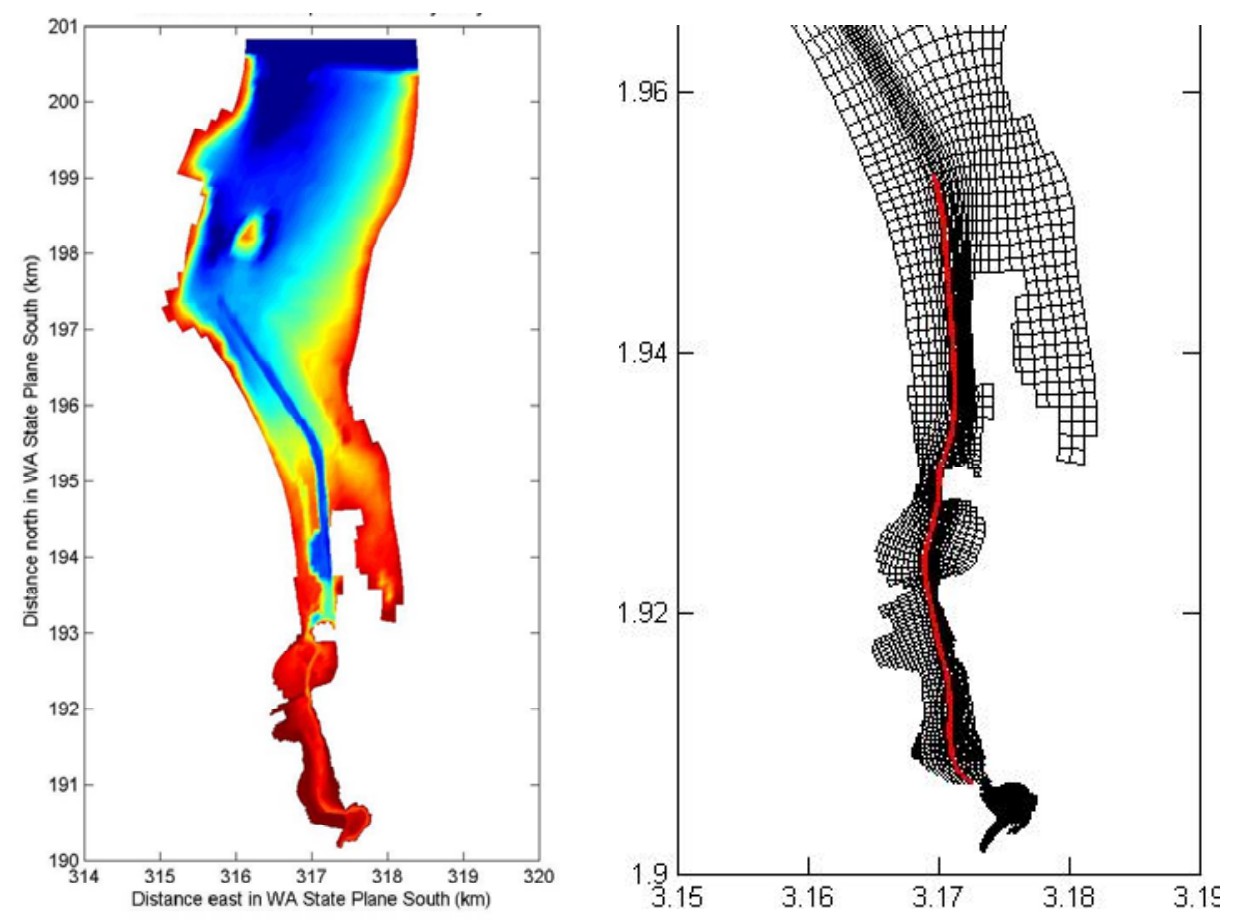

Figure 1. Bathymetry and grid used in hydrodynamic and sediment transport model of the Deschutes River Estuary. 

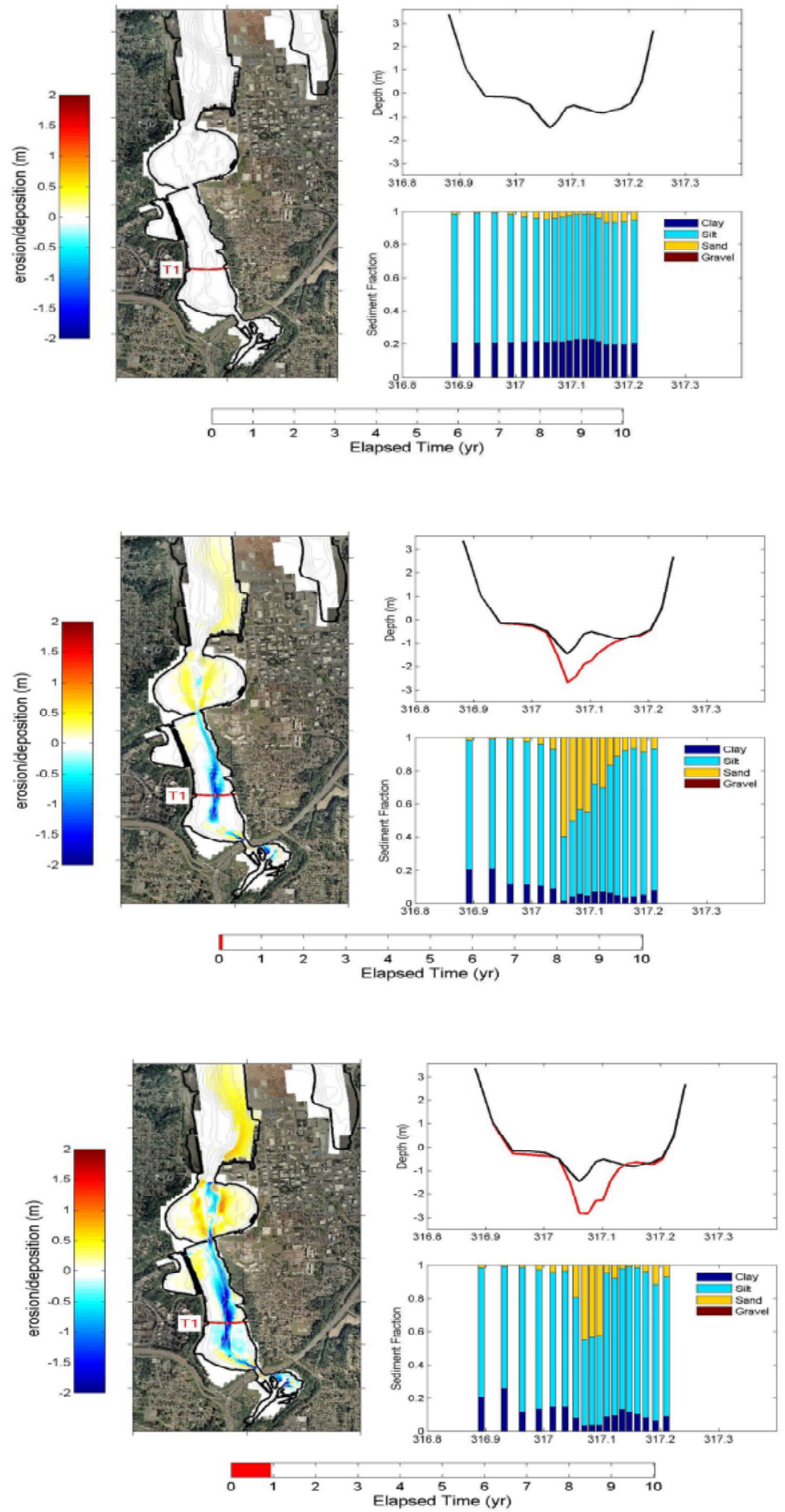

Figure 2. Maps of erosion/sedimentation, Middle Basin cross-section profile, and grain-size distribution at time $\mathrm{t}=0,1$ month, and 1 year. 


\title{
Recent Science-Based Restoration Planning by Puget Sound Nearshore Ecosystem Restoration Project (PSNERP)
}

\author{
By Curtis Tanner ${ }^{1,2}$ and Charles (Si) Simenstad ${ }^{1,3}$
}

\begin{abstract}
Evidence is mounting that Puget Sound's nearshore ecosystems are degrading due to a diverse array of anthropogenic stressors operating across a wide range of spatial scales. While any restoration of the Sound's shorelines will be beneficial, a concentrated effort to strategically restore and conserve large-scale ecosystem processes requires a comprehensive approach to guide actions from local to regional scales. Our fundamental tenet is that restoration of nearshore processes that form and maintain ecosystem structure will provide sustainable ecosystem goods, services and functions, such as habitat for fish, wildlife, and plants.

The Puget Sound Nearshore Ecosystem Restoration Project (PSNERP) is a General Investigation Study (GI) initiated in September 2001 by the U.S. Army Corps of Engineers and its local sponsor, the Washington Department of Fish and Wildlife. Additional partners contributing to this effort include other federal and state agencies, local governments, Native American tribal governments, non-governmental organizations (NGO), and industry representatives. Project goals are to identify significant ecosystem problems, evaluate potential solutions, and restore and preserve nearshore habitat in Washington State's Puget Sound basin.
\end{abstract}

Key Words: Nearshore, habitat restoration, Puget Sound, ecosystem processes

\section{Process-Based Approach}

We are developing and testing an approach to deliver a process-based, comprehensive, and spatially explicit assessment of restoration required for nearshore ecosystems of Puget Sound. With the guidance of our Nearshore Science Team (NST), we are developing and implementing a nearshore approach:

- Establishes restoration principles (Goetz and others, 2004) and other guidance recommendations (Fresh and others, 2004) for design and implementation of a comprehensive restoration program based on 'best available science';

- Advances a conceptual model (Simenstad and others, 2006) describing understanding of the relationships between nearshore ecosystem process, structure and function;

- Produced a nearshore typology to link observable structure (shoreforms) to underlying ecosystem processes;

11 Puget Sound Nearshore Ecosystem Restoration Project

22 U.S. Fish and Wildlife Service, Olympia, WA, curtis_tanner@fws.gov

3 3University of Washington, School of Aquatic and Fishery Sciences, Seattle, WA; simenstd@u.washington.edu 
- Developed a Sound-wide spatial data layer for the historic nearshore condition c.a. 1850;

- Conducts a change analysis by applying the nearshore typology to historic and current nearshore condition data;

- Infers anthropogenic alteration of nearshore processes from the change analysis;

- Evaluates a "future without" prognosis of continued change in Puget Sound's nearshore ecosystems in the absence of any restoration; and

- Proposes a strategic restoration response based on these results.

Following completion of this strategic needs assessment, partners will develop recommendations for large-scale restoration actions for an ecosystem restoration program. The final project "portfolio" will be developed by evaluation of potential projects using the results of the strategic needs assessment, and delivered in the GI final feasibility report.

\section{Change Analysis}

The current emphasis of PSNERP and particularly the NST is designing and implementing a pilot change analysis based on the Water Resource Inventory Areas 9 (WRIA9) sub-region of Puget Sound, which will then be used to develop a pilot strategic needs assessment based on the WRIA9 analysis. Review and revision of the results from this WRIA9 pilot analysis will subsequently be used to implement a comprehensive change analysis-strategic needs assessment for all of Puget Sound.

The purpose of a change analysis is to (1) detect changes in nearshore structure, (2) correlate those structural changes to associated changes in nearshore ecosystem processes, and (3) identify potential stressors associated with these changes, both within and adjacent (upland, offshore) to the nearshore domain. In more colloquial terms, the change analysis is designed to provide objective data that, in conjunction with the "future without" predictions of Puget Sound without a restoration project, will provide a spatially-explicit analysis of "What's broken and where" and "What's intact and where?" that can be inserted into the strategic needs assessment (fig. 1).

Our methods are based on new synoptic analysis of predominantly existing spatial data that allows comparison of the physical structure of nearshore ecosystems between about 1850 and1880 and current (about 2004) conditions (fig. 2). We utilize the shoreform categories of the PSNERP nearshore typology to classify shorelines and estuaries within broader scale accounting units (i.e., "AU" units) for both the historic and current conditions. Change between these two periods is assessed as (1) direct structural change (transition in shoreform, ecosystem components such as emergent marshes) and addition of anthropogenic features (e.g., 'attributes' such as shoreline armoring, overwater structures, boat ramps, levees) and (2) indirect change in land cover attributes (e.g., impervious surface, culverts, dams) inferred from the development of upland channelized and non-channelized drainages adjacent to (i.e., within 200-m 'buffer') and draining into (i.e., entire drainage area) each shoreline/estuarine accounting unit. This analysis is contingent on the basic assumptions that historic shoreline conditions can be inferred from historic maps (i.e., General Land Office surveys and US Coast and Geodetic Survey 't-sheets'), that historic upland conditions were undisturbed at this historic stage, and that characterization of current conditions can be used to infer changes to physical nearshore structure. While much of the current conditions spatial data were available, we have identified inaccurate and incomplete data that has constrained the reliability and interpretability of some changes, and are initiating revisions or new data collection to resolve these constraints. 
These changes are being organized and summarized across at least four hierarchal scales: (1) the accounting unit scale; (2) over 'process units' that reflect dominant nearshore ecosystem processes influencing physical structure (i.e., shoreline drift cells, salinity regions within estuaries); (3) within user-defined geographic units (e.g., Vashon/Maury islands, Elliott Bay/Duwamish River estuary, eastern Puget Sound shoreline); and, (4) over the entire pilot WRIA9 region. The resulting dataset of change metrics from shoreform transitions and shoreline/estuarine attribute changes is compiled into a comprehensive database that can be queried at any one of these scales, and potential interactive relationships among metrics and attributes can be explored (e.g., association between buffer condition and shoreline armoring).

In addition to change analysis and the subsequent strategic needs assessment, PSNERP is also pursuing other lines of inquiry required to complete the GI study. These include future conditions assessment ("future with") given a portfolio of restoration projects, and adaptive management and programmatic monitoring.

\section{Completing Study and Developing Restoration Strategy}

Continued and improved interaction between USGS CHIPS researchers and PSNERP Nearshore Science Team is recommended to advance these areas of mutual interest, and to better relate CHIPS efforts to science needs of related programs.

As it develops a comprehensive restoration strategy for Puget Sound, PSNERP must address many issues, including the following:

- Does a restoration strategy for many ESA listed species differ from one for an endangered ecosystem?

- How must programs focused on restoration of nearshore processes and physical habitat structure integrate with efforts to address remediation of environmental contamination?

- How can portfolios of multiple restoration projects be designed to optimize cumulative positive effects?

- What effects does upland development in contributing watersheds have on associated nearshore ecosystems?

Opportunities for collaboration between PSNERP and the USGS CHIPS team exist in these specific areas, as well as in areas of broader inquiry faced by the two programs. 


\section{References Cited}

Fresh, K., Simenstad, C., Brennan, J., Dethier, M., Gelfenbaum, G., Goetz, F., Logsdon, M., Myers, D., Mumford, T., Newton, J., Shipman, H., and Tanner, C., 2004, Guidance for protection and restoration of the nearshore ecosystems of Puget Sound: Puget Sound Nearshore Partnership Report No. 2004-02, Washington Sea Grant Program, University of Washington, Seattle, Washington. Available at http://pugetsoundnearshore.org.

Goetz, F., Tanner, C., Simenstad, C.S., Fresh, K., Mumford, T., and Logsdon, M., 2004, Guiding restoration principles: Puget Sound Nearshore Partnership Report No. 2004-03: Published by Washington Sea Grant Program, University of Washington, Seattle, Washington. Available at http://pugetsoundnearshore.org.

Simenstad, C., Logsdon, M., Fresh, K., Shipman, H., Dethier, M., and Newton, J., 2006, Conceptual model for assessing restoration of Puget Sound nearshore ecosystems: Puget Sound Nearshore Partnership Report No. 2006-03. Published by Washington Sea Grant Program, University of Washington, Seattle, Washington. Available at http://pugetsoundnearshore.org. 


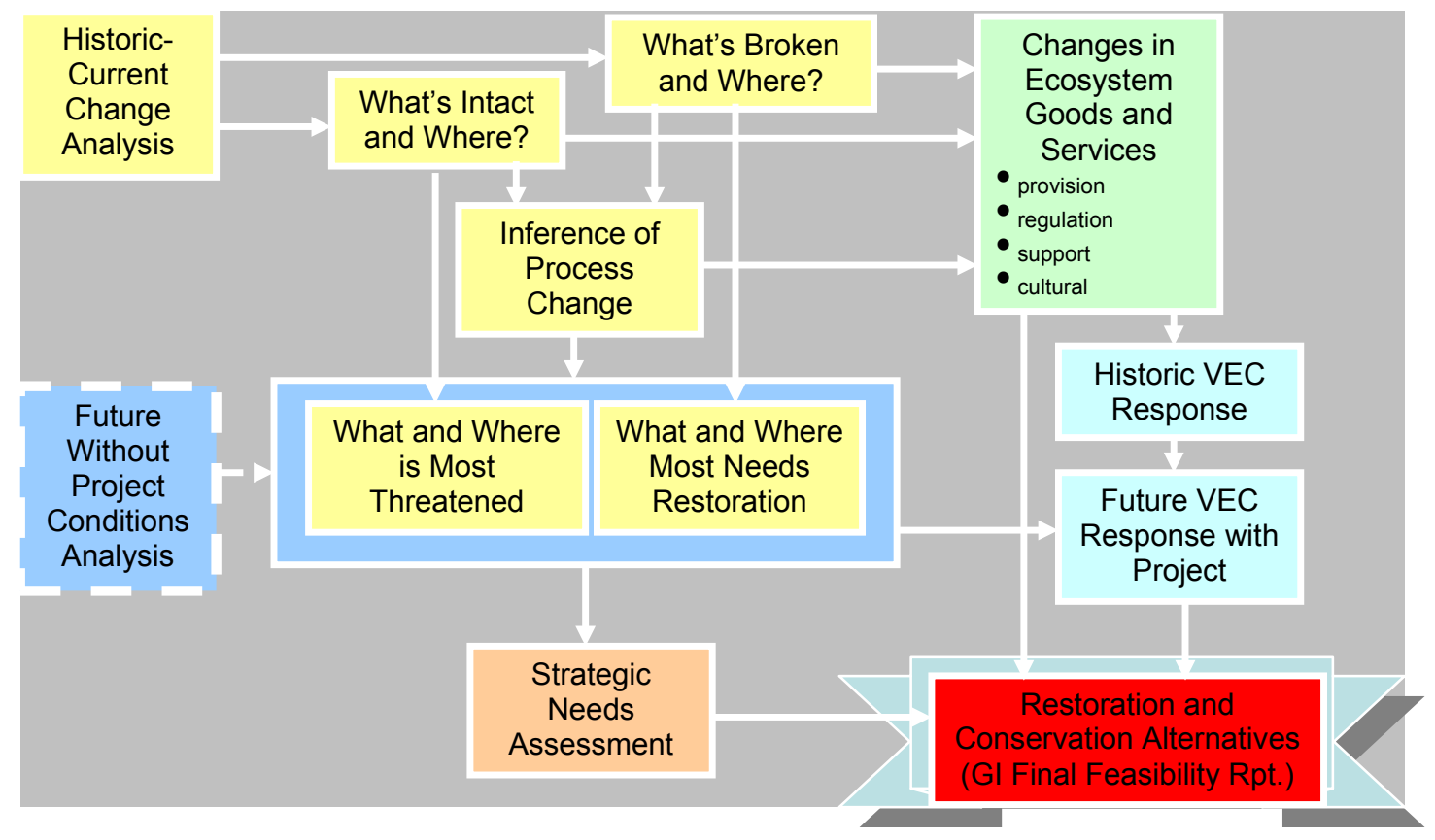

Figure 1. Sequence of analytical steps linking Puget Sound Nearshore Ecosystem Restoration Project (PSNERP) Change Analysis to Strategic Needs Assessment and development of restoration and conservation alternatives of General Investigation (GI) Final Feasibility Report. 


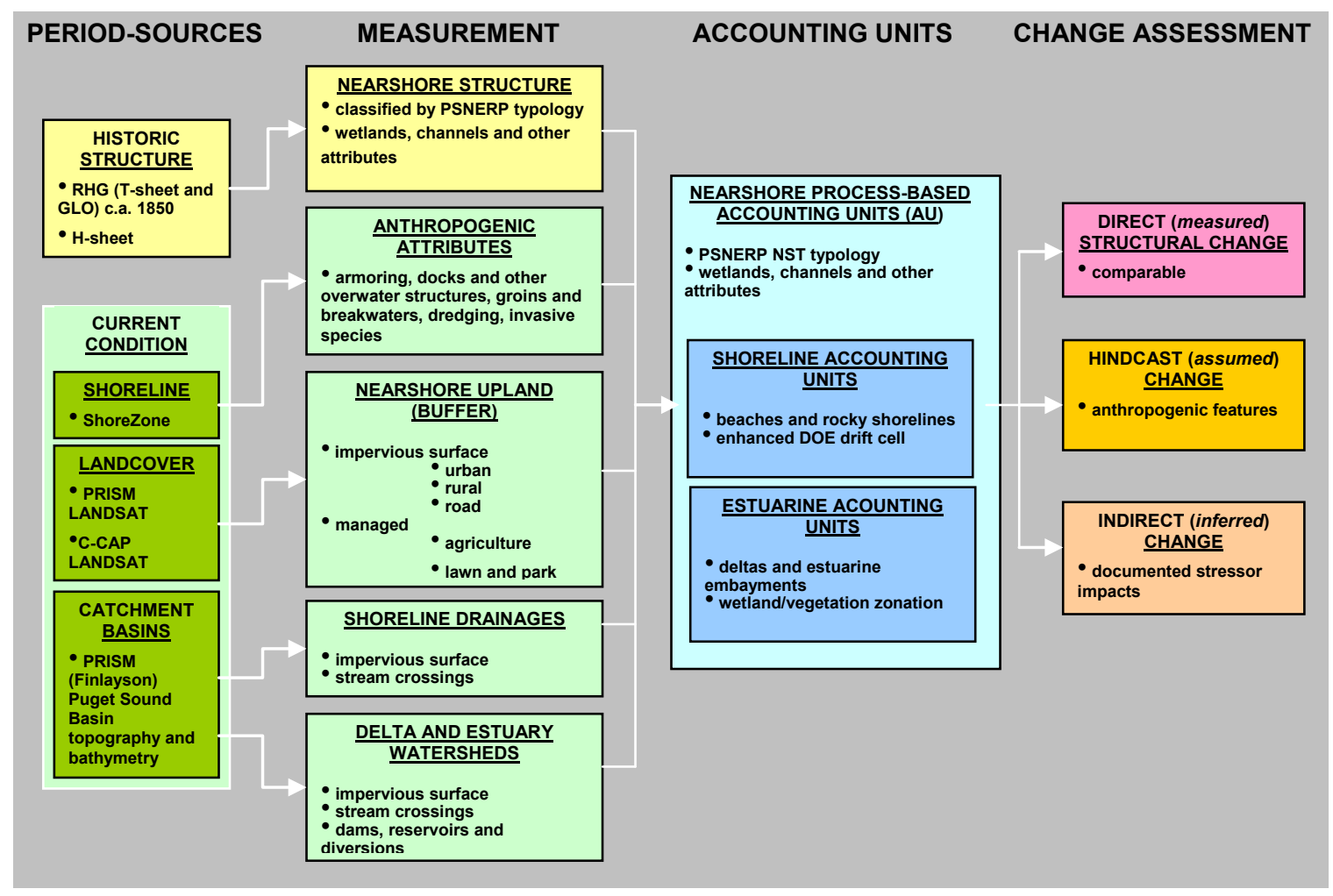

Figure 2. Synoptic approach to PSNERP change analysis. 


\section{Nearshore Habitat Program of the Washington Department of Natural Resources}

By Pete Dowty ${ }^{1}$, Blain Reeves ${ }^{1}$, Helen Berry ${ }^{1}$, James Selleck1, Tom Mumford ${ }^{1}{ }^{14}$, Mike Hannam¹, Sandy Wyllie-Echeverria², John Skalski², Jim Norris ${ }^{3}$, and lan Fraser ${ }^{3}$

\section{Abstract}

Research of the Washington Department of Natural Resources' Nearshore Habitat Program covers a wide range of projects in Washington State marine waters. Our mandate is to determine the health of nearshore habitat. Our goal is to provide timely and useful information on the status of nearshore habitat. Available datasets include the Whatcom Area Intertidal Habitat Inventory, the Skagit Area Intertidal Habitat Inventory, the WA ShoreZone Inventory and Greater Puget Sound inventory, data from the Submerged Vegetation Monitoring Project, and data from kelp (Macrocystis integrifolia and Nereocystis luetkeana) and eelgrass (Zostera marina) monitoring. Results from Olympic Peninsula kelp monitoring show that only one sample area, Protection Island, had large declines in kelp canopy cover. Results from Puget Sound-wide eelgrass monitoring show declining trends in bed area in Hood Canal and certain San Juan Archipelago embayments. Program shapefiles and data from are available on the Nearshore Habitat Program page: http://www.dnr.wa.gov/htdocs/aqr/nshr/index.html.

Key Words: nearshore habitat, kelp, Macrocystis integrifolia, Nereocystis luetkeana, eelgrass, Zostera marina

\section{Puget Sound Assessment and Monitoring Program (PSAMP)}

The Washington Department of Natural Resources (DNR) Nearshore Habitat Program is under the direction of the Puget Sound Assessment and Monitoring Program (PSAMP), a program within the Puget Sound Action Team. PSAMP currently delivers basic information to assess the health of Puget Sound, provides a synthesis of PSAMP results with other Puget Sound work, and establishes a network of State, local and Federal scientists.

Current PSAMP Partners include the State Departments of Ecology, Fish and Wildlife, Health, Natural Resources, and the Puget Sound Action Team. Federal partners include EPA, NOAA Fisheries, U.S. Fish and Wildlife Service. Other partners are University of Washington and King County Department of Natural Resources and Parks.

${ }^{1}$ Washington Department of Natural Resources, Aquatic Resources Division, Science Support Section, Olympia, WA University of Washington, Seattle, WA

${ }^{3}$ Marine Resources Consultants, Port Townsend, WA

4tom.mumford@wadnr.gov 
Areas monitored include toxics (sediment contaminants, fish contaminants, fish liver disease), species status and trends (groundfish and marine birds), pathogens and nutrients (fecal coliform in shellfish areas, shellfish biotoxins, marine and freshwater nutrients and pathogens), and habitat status and trends (submerged vegetation, marine and freshwater quality, including dissolved oxygen).

\section{Intertidal Habitat Inventory/Survey}

DNR 'core' data includes the following intertidal habitat inventory/survey datasets: 1995 Whatcom Area Intertidal Habitat Inventory, 1996 Skagit Area Intertidal Habitat Inventory, the 2000 WA ShoreZone Inventory and 2004+ Greater Puget Sound Inventory, as well as an eelgrass monitoring dataset from the Submerged Vegetation Monitoring Project (2000-2004+).

The Whatcom and Skagit inventories (fig. 1) were collected using a CASI Multispectral Airborne Sensor (4-m resolution). Coverages are available for intertidal vegetation (fig. 2) and shoreline characteristics (sand/cobble, open/protected).

The Washington ShoreZone dataset, covering all Washington marine shorelines (fig. 3), was created using a helicopter-based survey. Physical variables mapped on the shoreline include bulkheads, sediment variables, and energy/exposure. Biological variables include vegetation types (continuous/patchy/absent; fig. 4).

\section{Kelp Monitoring}

DNR has monitored the floating canopy of the kelp species Macrocystis integrifolia and Nereocystis luetkeana from 1989 to present. The Olympic Peninsula Dataset (1989-2000+; fig. 5) is available; the only area of major loss of kelp canopy is at Protection Island (fig. 6). Efforts are underway to monitor floating kelp canopies in Greater Puget Sound (2004+).

\section{Eelgrass (Zostera marina) Monitoring}

Eelgrass provides many ecological functions: spawning grounds for Pacific herring, migration corridors for juvenile salmon, feeding/foraging habitat for Great Blue Heron and Black Brant Geese. It also stabilizes nearshore sediments and may play an important role in overall oxygen budget.

The approach is based on rotating-frame stratified random sampling (fig. 7). We stratified Puget Sound into one of five regions and three bed types: flats, wide fringes, and fringes (fig. 8). We continually sample a set of core sites without rotating out of the sampling frame. Key parameters estimated are bed area and maximum depth limits. Data are collected using underwater videography along random transects placed within defined bed areas. We have made a tradeoff between intensive and extensive sampling (fig. 9).

The results show that the Puget Sound-wide coverage of eelgrass to be about 20,000 ha. At the Sound-wide level, this amount appears to be stable. However, the data show declining trends bed area in Hood Canal and certain San Juan Archipelago embayments. About 27 percent of the overall eelgrass bed area is in the Padilla/Samish Bay complex. 


\section{Next Steps}

A newly funded study is underway to determine the causes of the changes seen in eelgrass abundance and distribution, linking stressors to these changes to inform resource managers.

The final 2005 eelgrass monitoring will be released in March 2007 (reports to be available from DNR). The 2006 monitoring has been completed and analyzed. Results are expected to be published in late 2007.

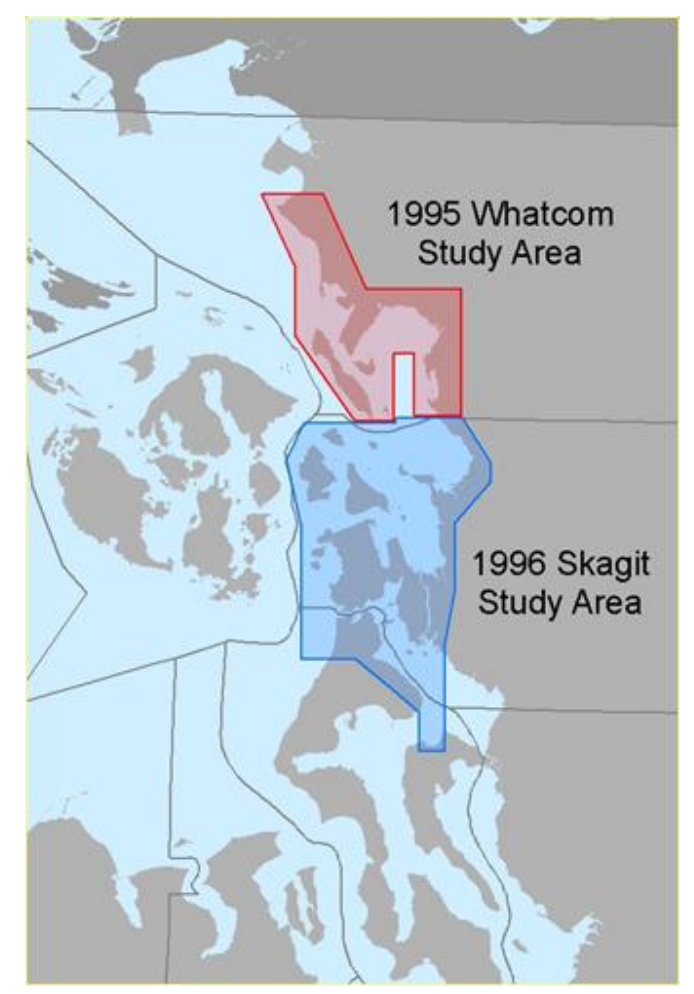

Figure 1. Extent of study area coverages of Puget Sound intertidal habitat inventory, Whatcom (1995) and Skagit (1996) Counties. 


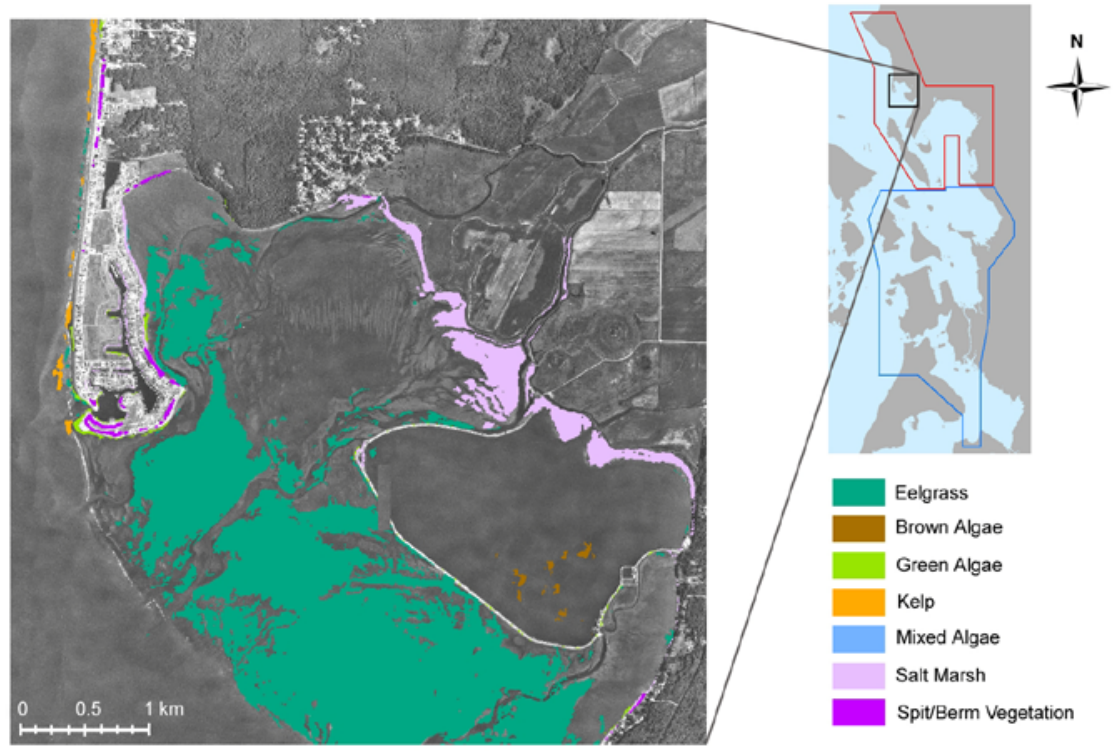

Figure 2. Intertidal vegetation classes in Lummi Bay from the 1995 Whatcom Intertidal Habitat Inventory.

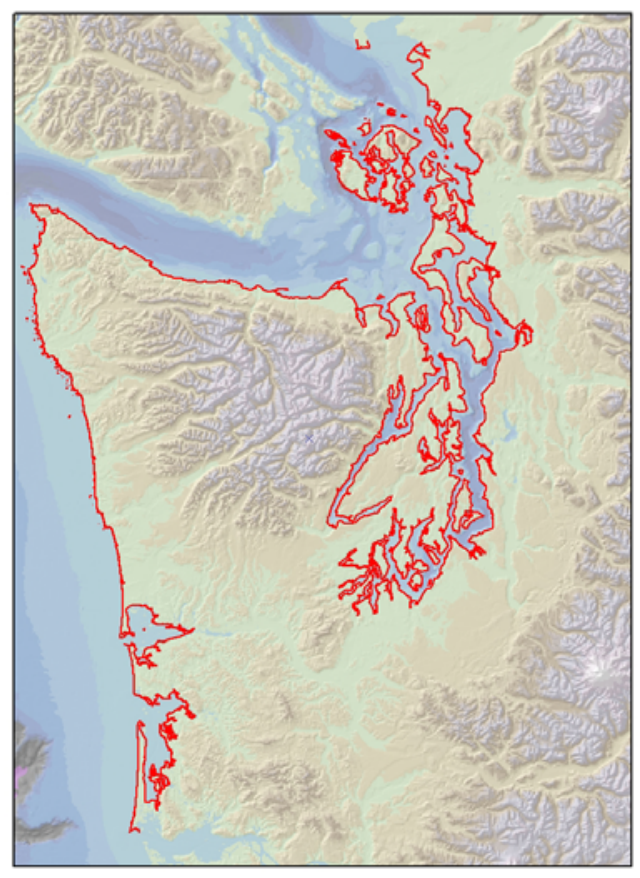

Figure 3. Extent of coverage (red) of ShoreZone data, Washington, which includes both physical and biological variables. 


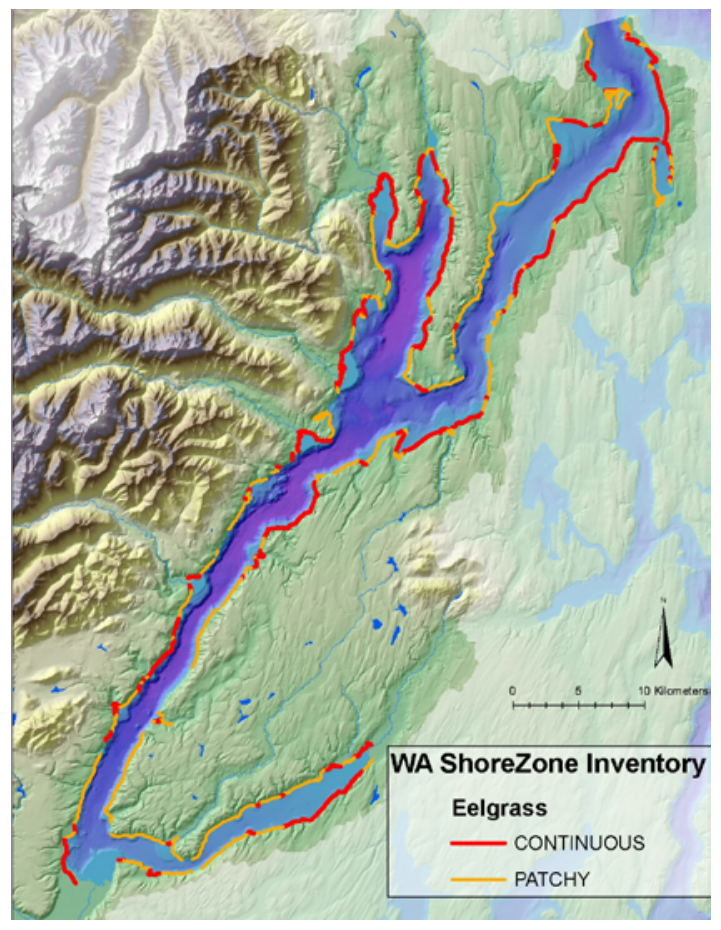

Figure 4. Distribution of eelgrass (Zostera marina) in Hood Canal, Washington. 


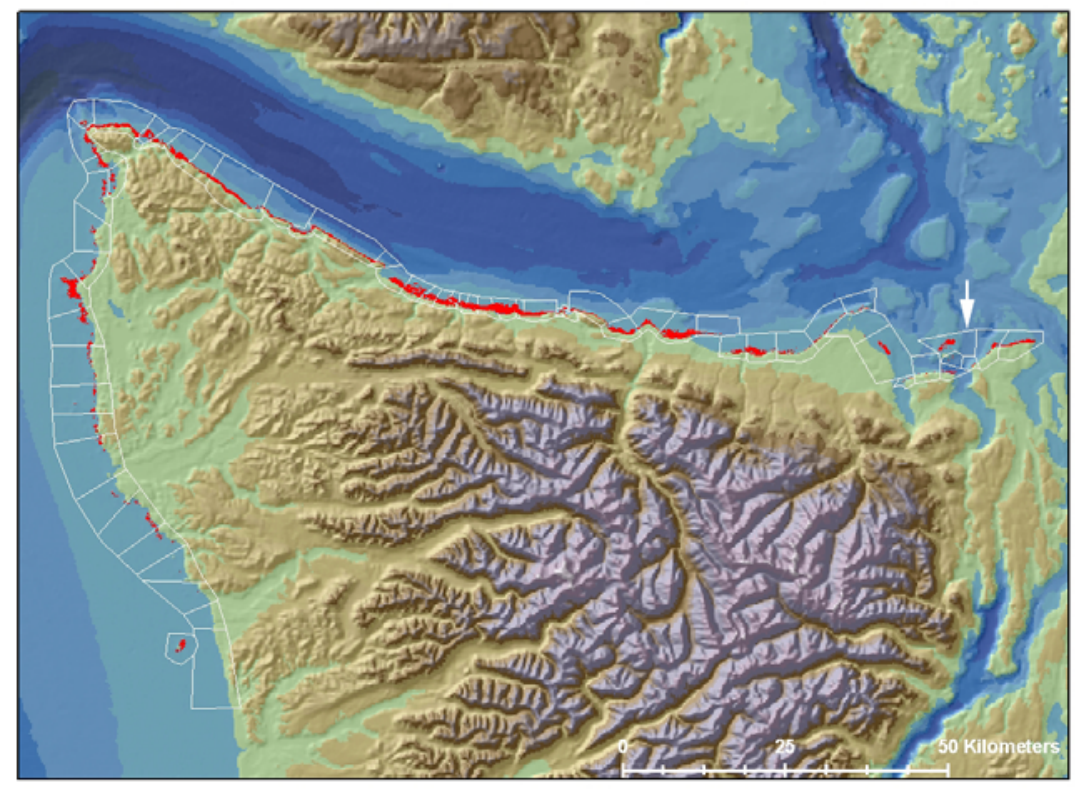

Figure 5. Study area units (white) for kelp (Macrocystis integrifolia and Nereocystis luetkeana) canopy (red) change analysis in Washington State, 1989-2000. The only major loss is at Protection Island (white arrow; fig. 6). 

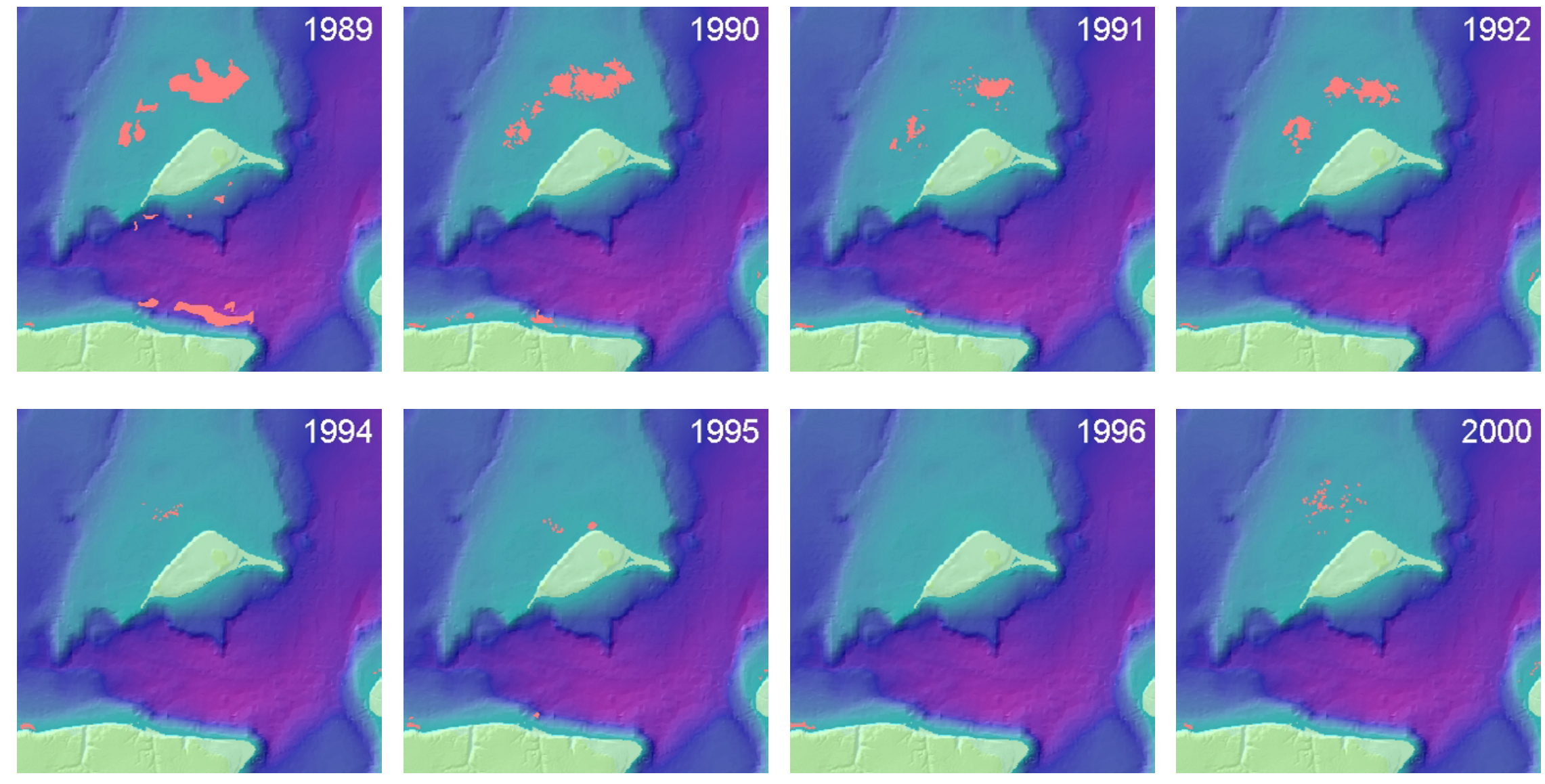

Figure 6. Loss of floating kelp canopy (Nereocystis luetkeana, orange) from Dallas Bank, Protection Island, Strait of Juan de Fuca, $1989-2000$. 


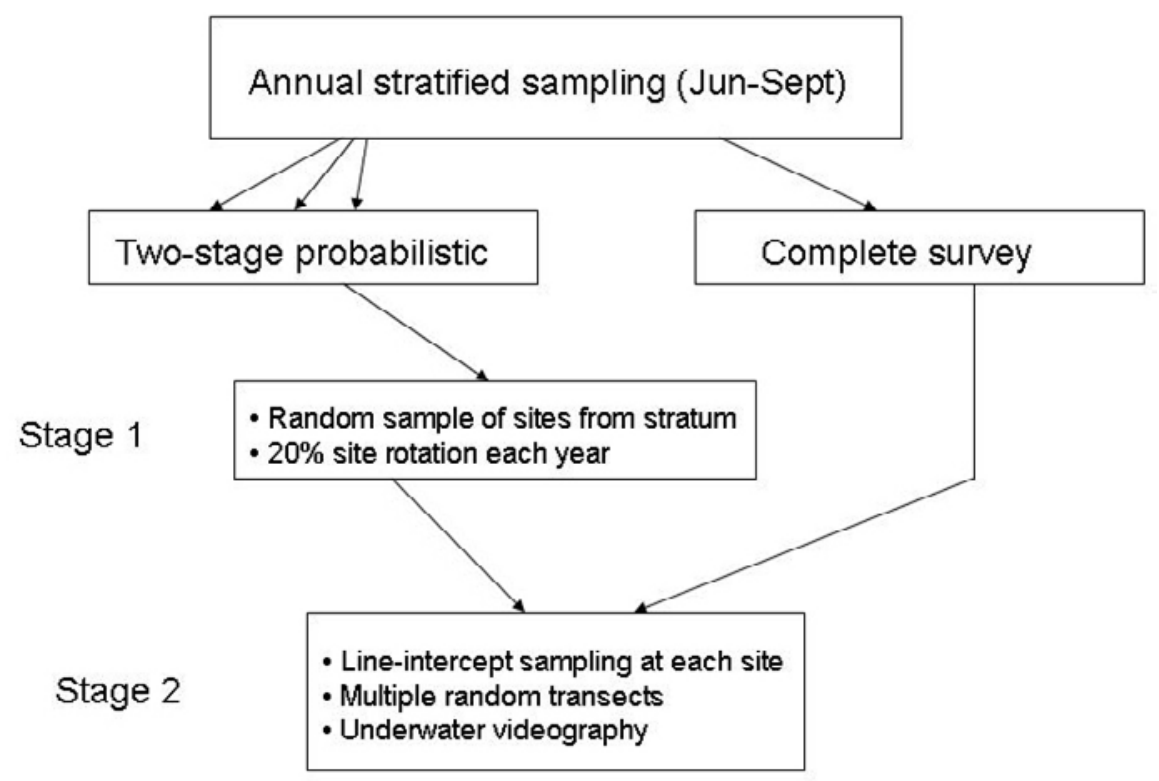

Figure 7. Monitoring approach for eelgrass (Zostera marina) monitoring.

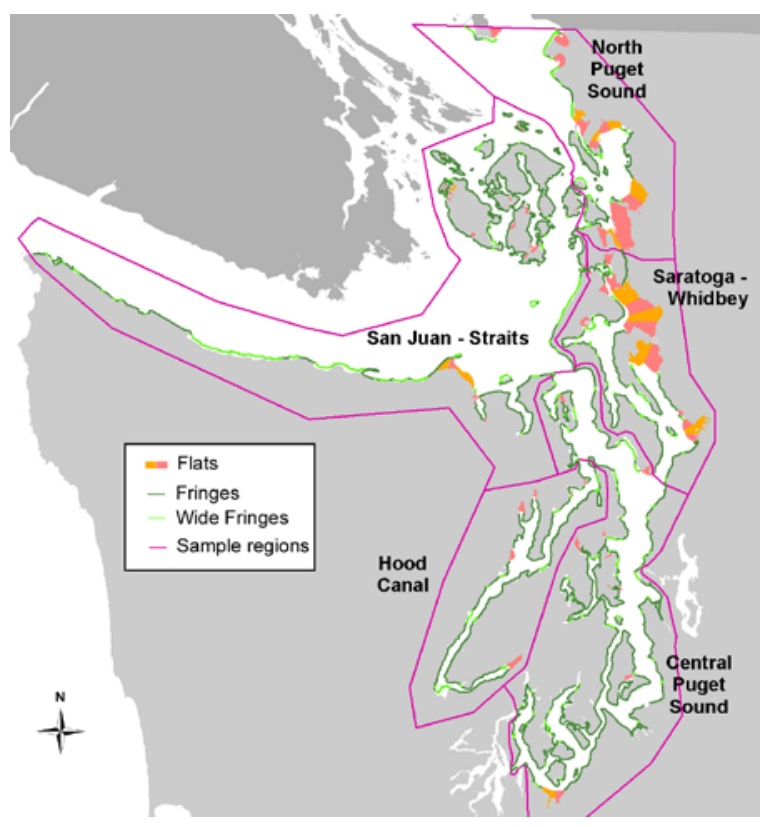

Figure 8. Regions for Submerged Vegetation Monitoring Project sampling and distribution of fringe and flat sites. 
Intensive

Low
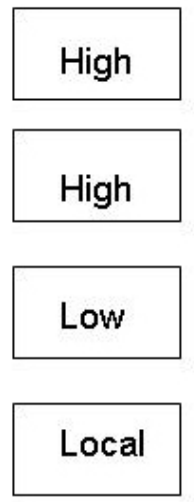

Year
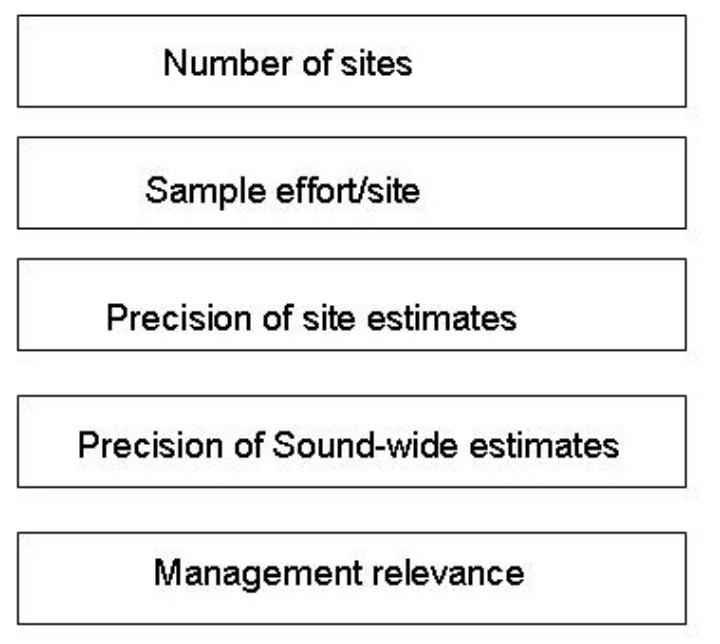

Time scale of management

\section{Extensive}

\section{High}
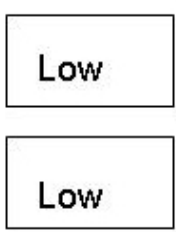

High

\section{State}

Decade

Figure 9. Tradeoff made in the Submerged Vegetation Monitoring Project sampling between intensive versus extensive sampling. 


\section{Data Sets and Resources}

(http://www.dnr.wa.gov/htdocs/aqr/nshr/index.html)

Berry, H., and Ritter, R., Puget Sound Intertidal Habitat Inventory, 1997, 1995

Vegetation and Shoreline Characteristics Classification Methods. Report for Washington Department of Natural Resources, Aquatic Resources Division, Olympia, WA.

Berry, H.D., Harper, J.R. Mumford, T.F., Jr., Bookheim, B.E., Sewell, A.T., and Tamayo, L.J., 2001, Washington State ShoreZone Inventory User's Manual: Washington Department of Natural Resources, Aquatic Resources Division, Olympia, WA. Berry, H.D., Harper, J.R., Mumford, T.F., Jr., Bookheim, B.E., Sewell, A.T., and Tamayo, L.J., 2001, Washington State ShoreZone Inventory Data Dictionary. Washington Department of Natural Resources, Aquatic Resources Division, Olympia, WA.

Berry, H.D., Sewell, A.T., Wyllie-Echeverria, S., Reeves, B.R., Mumford, T.F., Jr., Skalski, J.R., Zimmerman, R.C., and Archer, J., 2003, Puget Sound Submerged Vegetation Monitoring Project: 2000-2002 Monitoring: Washington State Department of Natural Resources, Olympia, WA.

Dowty, P., Reeves, B., Berry, H., Wyllie-Echeverria, S., Mumford, T., Sewell, A., Milos, P., and Wright, R., 2005, Puget Sound Submerged Vegetation Monitoring Project 2003-2004 Monitoring Report: Washington State Department of Natural Resources, Olympia, WA.

Nearshore Habitat Program, 1997, 1995 Puget Sound Intertidal Habitat Inventory, CDROM: Washington Department of Natural Resources, Olympia, WA.

Nearshore Habitat Program, 1999, 1996, Puget Sound Intertidal Habitat Inventory, CDROM: Washington Department of Natural Resources, Olympia, WA.

Nearshore Habitat Program, 2001, The Washington State ShoreZone Inventory: CDROM. Washington Department of Natural Resources, Olympia, WA. 


\section{Workshop Participants}

\begin{tabular}{|c|c|c|}
\hline Cindy Barton & Matt Bierne & Bob Black \\
\hline U.S. Geological Survey & Lower Elwha Klallam Tribe & U.S. Geological Survey \\
\hline Washington Water Science Center & Port Angeles, WA & Washington Water Science Center \\
\hline $\begin{array}{l}\text { Tacoma, WA } \\
\text { cbarton@usgs.gov }\end{array}$ & bierne@elwha.nsn.us & $\begin{array}{l}\text { Tacoma, WA } \\
\text { rwblack@usgs.gov }\end{array}$ \\
\hline John Clemens & Paul Dorn & Amy Draut \\
\hline U.S. Geological Survey & Suquamish Tribe & U.S. Geological Survey \\
\hline Washington Water Science Center & Suquamish, WA & Coastal \& Marine Geology \\
\hline Tacoma, WA & pdorn@suquamish.nsn.us & Santa Cruz, CA \\
\hline jclemens@usgs.gov & & adraut@usgs.gov \\
\hline Jeff Duda & Kurt L. Fresh & Tracy Fuentes \\
\hline U.S. Geological Survey & NOAA Fisheries & U.S. Geological Survey \\
\hline Western Fisheries Research Center & Northwest Fisheries Science Center & Western Regional Office - Biology \\
\hline Seattle, WA & Seattle, WA & Seattle, WA \\
\hline jeff_duda@usgs.gov & kurt.fresh@noaa.gov & tfuentes@usgs.gov \\
\hline Jeff Gaeckle & Guy Gelfenbaum & Eric Grossman \\
\hline WA Department of Natural Resources & U.S. Geological Survey & U.S. Geological Survey \\
\hline Olympia, WA & Coastal \& Marine Geology & Coastal \& Marine Geology \\
\hline jeff.gaeckle@wadnr.gov & 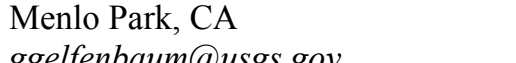 & Santa Cruz, CA \\
\hline Bernie Hargrave & Paul Hershberger & \\
\hline US Army Corps of Engineers & U.S. Geological Survey & Greg Hood \\
\hline Seattle, WA & Western Fisheries Research Center & Skagit River System Cooperative \\
\hline bernard.l.hargrave.jr@usace.army.mil & Nordland, WA & La Conner, WA \\
\hline & phershberger@usgs.gov & ghood@skagitcoop.org \\
\hline Lief Horwitz & Sam Johnson & Robert Koeppen \\
\hline U.S. Geological Survey & U.S. Geological Survey & U.S. Geological Survey \\
\hline Western Regional Office - Biology & Coastal \& Marine Geology & Western Region \\
\hline Seattle, WA & Santa Cruz/Menlo Park, CA & Director's Office \\
\hline lief_horwitz@usgs.gov & sjohnson@usgs.gov & Seattle, WA \\
\hline & & rkoeppen@usgs.gov \\
\hline Chris Konrad & Lynne Koontz & Bill Labiosa \\
\hline U.S. Geological Survey & U.S. Geological Survey & U.S. Geological Survey \\
\hline Washington Water Science Center & USGS Fort Collins Science Center & Western Fisheries Research Center \\
\hline Tacoma, WA & Fort Collins, CA & Menlo Park, CA \\
\hline cpkonrad@usgs.gov & koontzl@usgs.gov & blabiosa@usgs.gov \\
\hline Jessie Lacy & Kim Larsen & Theresa Liedtke \\
\hline U.S. Geological Survey & U.S. Geological Survey & U.S. Geological Survey \\
\hline Coastal \& Marine Geology & Western Fisheries Research Center & Western Fisheries Research Center \\
\hline Santa Cruz, CA & Seattle, WA & Cook, WA \\
\hline jlacy@usgs.gov & kim_larsen@usgs.gov & theresa_liedtke@usgs.gov \\
\hline Mark Mastin & Mary McGann & Mike McHenry \\
\hline U.S. Geological Survey & U.S. Geological Survey & Lower Elwha Klallam Tribe \\
\hline Washington Water Science Center & Coastal \& Marine Geology & Port Angeles, WA \\
\hline Tacoma, WA & Menlo Park, CA & mchenry@elwha.nsn.us \\
\hline mcmastin@usgs.gov & mmcgann@usgs.gov & \\
\hline
\end{tabular}




\begin{tabular}{|c|c|c|}
\hline Alan Mikuni & Tom Mumford & Tony Paulson \\
\hline Western Regional Office - Geography & PSNERP Science Team & U.S. Geological Survey \\
\hline Menlo Park, CA & WA Dept. of Natural Resources & Washington Water Science Center \\
\hline \multirow[t]{2}{*}{ amikuni@usgs.gov } & Olympia, WA & Tacoma, WA \\
\hline & tom.mumford@wadnr.gov & apaulson@usgs.gov \\
\hline Vivian Queija & Reg Reisenbichler & Rusty Rodriguez \\
\hline U.S. Geological Survey & U.S. Geological Survey & U.S. Geological Survey \\
\hline National Mapping Division & Western Fisheries Research Center & Western Fisheries Research Center \\
\hline Seattle, WA & Seattle, WA & Seattle, WA \\
\hline vqueija@usgs.gov & reg_reisenbichler@usgs.gov & rusty_rodriguez@usgs.gov \\
\hline Dennis Rondorf & Bob Rosenbauer & Natalie Sexton \\
\hline U.S. Geological Survey & U.S. Geological Survey & U.S. Geological Survey \\
\hline Western Fisheries Research Center & Coastal \& Marine Geology & USGS Fort Collins Science Center \\
\hline Cook, WA & Menlo Park, CA & Fort Collins, $\mathrm{CO}$ \\
\hline dennis_rondorf@usgs.gov & brosenbauer@usgs.gov & sextonn@usgs.gov \\
\hline Frank Shipley & Hugh Shipman & Charles (Si) Simenstad \\
\hline U.S. Geological Survey & WA Department of Ecology & PSNERP Science Team \\
\hline Western Regional Office - Biology & Olympia, WA & University of Washington \\
\hline Seattle, WA & hshi461@ecy.wa.gov & School of Aquatic and Fishery Sciences \\
\hline \multirow{2}{*}{ frank_shipley@usgs.gov } & & Seattle, WA \\
\hline & & simenstd@u.washington.edu \\
\hline Andrew Stevens & Peter Swarzenski & Renee Takesue \\
\hline U.S. Geological Survey & U.S. Geological Survey & U.S. Geological Survey \\
\hline Coastal \& Marine Geology & Coastal \& Marine Geology & Coastal \& Marine Geology \\
\hline Menlo Park, CA & Santa Cruz, CA & Santa Cruz, CA \\
\hline astevens@usgs.gov & pswarzen@usgs.gov & rtakesue@usgs.gov \\
\hline Curtis Tanner & Christian Torgersen & Alicia Torregrosa \\
\hline PSNERP Science Team & U.S. Geological Survey & U.S. Geological Survey \\
\hline US Fish and Wildlife Service & Forest and Rangeland Ecological & Geographic Science Center Research and \\
\hline Olympia, WA & Research Science Center & Technology Team \\
\hline \multirow[t]{2}{*}{ curtis_tanner@fws.gov } & Seattle, WA & Menlo Park, CA \\
\hline & ctorgersen@usgs.gov & atorregrosa@usgs.gov \\
\hline Marijke van Heeswijk & Ray Watts & Brian Winter \\
\hline U.S. Geological Survey & U.S. Geological Survey & Olympic National Park \\
\hline Washington Water Science Center & Geography, Central Region, & Port Angeles, WA \\
\hline Tacoma, WA & National Mapping Division & brianwinter@nps.gov \\
\hline heeswijk@usgs.gov & Fort Collins, CO & \\
\hline & rwatts@usgs.gov & \\
\hline \multicolumn{3}{|l|}{ David Woodson } \\
\hline \multicolumn{3}{|l|}{ U.S. Geological Survey } \\
\hline \multicolumn{3}{|l|}{ Western Fisheries Research Center } \\
\hline \multicolumn{3}{|l|}{ Seattle, WA } \\
\hline davidwoodson@usgs.gov & & \\
\hline
\end{tabular}

